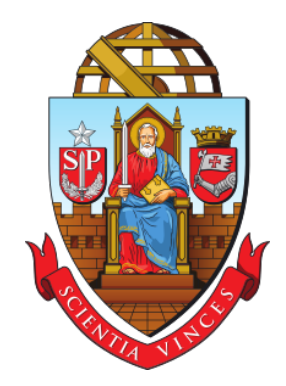

Universidade de São Paulo

Faculdade de Filosofia, Letras e Ciências Humanas

Programa de Pós-Graduação em Ciência Política

\title{
A Religião Distrai os Pobres? \\ Pentecostalismo e Voto Redistributivo no Brasil
}

Victor Augusto Araújo Silva

São Paulo, 2019 
Victor Augusto Araújo Silva

\section{A Religião Distrai os Pobres?}

\section{Pentecostalismo e Voto Redistributivo no Brasil}

Tese de Doutorado apresentada ao Programa de Pós-Graduação em Ciência Política da Universidade de São Paulo como parte dos requisitos necessários para a obtenção do Título de Doutor em Ciência Política.

Universidade de São Paulo

Faculdade de Filosofia, Letras e Ciências Humanas

Programa de Pós-Graduação em Ciência Política

Orientador: Marta Teresa da Silva Arrecthe

São Paulo

2019 
Autorizo a reprodução e divulgação total ou parcial deste trabalho, por qualquer meio convencional ou eletrônico, para fins de estudo e pesquisa, desde que citada a fonte.

Catalogação na Publicação

Serviço de Biblioteca e Documentação

Faculdade de Filosofia, Letras e Ciências Humanas da Universidade de São Paulo

Silva, Victor Augusto Araújo

A Religião Distrai os Pobres? Pentecostalismo e Voto Redistributivo no Brasil / Victor Augusto Araújo Silva ; orientadora Marta Teresa da Silva Arrecthe. - São Paulo, 2019.

$207 \mathrm{f}$.

Tese (Doutorado)- Faculdade de Filosofia, Letras

e Ciências Humanas da Universidade de São Paulo.

Departamento de Ciência Política. Área de

concentração: Ciência Política.

1. Religião. 2. Pentecostalismo. 3.

Redistribuição. 4. Eleiçoões. 5. Brasil. I. Arrecthe, Marta Teresa da Silva, orient. II. Título. 


\title{
A Religião Distrai os Pobres? \\ Pentecostalismo e Voto Redistributivo no Brasil
}

\begin{abstract}
Tese de Doutorado apresentada ao Programa de Pós-Graduação em Ciência Política da Universidade de São Paulo como parte dos requisitos necessários para a obtenção do Título de Doutor em Ciência Política.
\end{abstract}

Trabalho aprovado. São Paulo, 19 de Dezembro de 2019:

Marta Teresa da Silva Arrecthe

USP (Orientadora)

Fernando Limongi

USP e EESP-FGV

Jairo Nicolau

CPDOC-FGV

\section{Bruno Reis}

UFMG

São Paulo

2019 
Ao meu avô Vitório, pelo exemplo de resiliência e à Patrícia Martuscelli, pelo amor incondicional. 


\section{Agradecimentos}

Agradeço a Deus pelo privilégio de poder me dedicar a algo que me inspira e me motiva a superar continuamente minhas limitações.

Esta tese não teria sido possível sem o contínuo apoio de muitas pessoas que estiveram comigo até aqui. Sou grato à minha família pelo suporte durante a infância e em outros momentos da vida adulta, em especial aos meus pais, Laura e Vitório, meu Tio Toni e o meu avô Vitório. Este último empenhou todas as suas forças para que eu fosse o primeiro da família a cursar (e terminar) o ensino superior. Sou muito grato à minha esposa, Patrícia Martuscelli, pela sua paciência e amor diários, que me permitiram chegar até o final dessa jornada preservando algum nível de sanidade. Sou também grato aos queridos Cris, Fran, Leslie, Mark, Luciano, Charles e Du, pelo suporte emocional e psicológico.

No âmbito profissional, fui beneficiado pelo entusiasmo de várias pessoas que me acompanham desde a graduação na UFMG, instituição à qual sou imensamente grato por ter me formado e introduzido no mundo da ciência. Agradeço especialmente a Carlos Eduardo Guerra, Magna Inácio, Antônio Mitre, Jerônimo Muniz, Carlos Ranulfo, Bruno Reis, Silvio Salej e Manoel Santos. Na Pós-graduação, tive a sorte de ser orientado por Marta Arretche e Fernando Limongi que trabalharam incansavelmente para que eu pudesse superar meus inúmeros desafios e sonhar com voos mais altos. À primeira, orientadora deste trabalho, serei sempre grato pelo brilhantismo, seriedade, humanidade e amizade. Este trabalho não existiria sem a sua incomparável capacidade de organizar o caos e passar tranquilidade nos momentos decisivos. Contudo, todos 
os eventuais erros e equívocos restantes são de minha inteira responsabilidade. Sou também grato pela mentoria, em diferentes momentos e situações, de Acir Almeida, Natália Salgado Bueno, Lorena Barberia, Lucas Cunha, Eduardo Marques, Umberto Mignozzetti, Bruno Speck e Glauco Peres da Silva.

Dezenas de pessoas contribuíram, de forma direta ou indireta, para a realização deste trabalho. Merecem especial menção Rogério Barbosa, Paulo Flores, Hellen Guicheney, Maurício Izumi, Eduardo Lazzari, Patrícia Martuscelli e Cristina Nabuco. A esta última, sou grato pela cuidadosa revisão de texto. Agradeço, ainda, a Rodrigo Menegat por compartilhar comigo o código para a geração dos dados georeferenciados utilizados no capítulo 4 da tese.

Finalmente, sou grato à FAPESP pela bolsa de doutorado no Brasil (processo 2016/23215-0) e pelo financiamento do meu estágio de pesquisa no exterior na Duke University (processo 2017/09789-7). A propósito, agradeço a Pablo Beramendi por sua valiosa orientação durante minha estadia na Duke. Agradeço à Shirley, do Centro de Estudos da Metrópole (CEM/Cepid), por todo apoio operacional para a realização deste trabalho, bem como aos funcionários do Departamento de Ciência Política da USP, em especial, Vasne e Márcia, pelo contínuo suporte logístico. 
"A religião é aquilo que impede os pobres de matarem os ricos".

Napolão Bonaparte 


\section{Resumo}

A expectativa de que a desigualdade de renda produz pressão por redistribuição baseiase na presunção de que indivíduos abaixo da mediana de rendimentos e com expectativa de ascensão social deveriam votar em partidos com propostas redistributivas. Curiosamente, evidências de contextos diversos sugerem que a demanda por redistribuição tende a diminuir à medida que a desigualdade cresce. $\mathrm{O}$ que nos remete à seguinte questão: por que pobres não votam em plataformas eleitorais redistributivas? Neste trabalho, proponho uma explicação para o caso brasileiro que considera o efeito da religião sobre o comportamento eleitoral dos indivíduos. Especificamente, argumento que as lideranças pentecostais atuam como cabos eleitorais (brokers) para mediar a relação entre candidatos e fiéis (eleitores) de baixa renda e inviabilizar a candidatura de políticos que não se identificam com os valores morais defendidos por este grupo evangélico. As evidências para as eleições presidenciais brasileiras (2002-2018) indicam fraco desempenho dos candidatos de esquerda entre os eleitores evangélicos pentecostais, resultado que contrasta com o bom desempenho desses mesmos candidatos entre eleitores católicos e evangélicos tradicionais. Também investigo o efeito da transição religiosa - aumento dos evangélicos pentecostais em detrimento dos cristãos católicos - sobre a votação do Partido dos Trabalhadores (PT), o partido de esquerda mais competitivo, com maior capilaridade nos municípios brasileiros, maior representação no Congresso Nacional e que logrou sucesso eleitoral em quatro eleições presidenciais consecutivas entre 2002 e 2014 . Os resultados sugerem melhor desempenho dos candidatos petistas em eleições presidenciais nos municípios com predominância católica, resultado que se mantém mesmo quando controlado o efeito exercido pela região Nordeste (região majoritariamente católica). Embora, à primeira vista, a transição religiosa seja um fenômeno meramente demográfico, a reconfiguração dos setores religiosos da sociedade brasileira possui consequências eleitorais importantes. Os achados deste trabalho também indicam que o pentecostalismo afeta a resposta dos eleitores pobres às políticas de redistribuição de renda. O aumento de bem-estar induzido pelo Programa Bolsa Família (PBF) produziu retornos eleitorais para o PT apenas entre os beneficiários não-pentecostais e nos locais com alta concentração de pobres católicos. Esses resultados são robustos e se mantêm em diferentes especificações utilizando dados agregados e evidências de nível individual e se mostram consistentes mesmo quando confrontados com mecanismos explicativos alternativos. Em conjunto, as evidências apresentadas neste trabalho ajudam a explicar porque eleitores de baixa, em contextos com alta desigualdade, podem não votar por redistribuição de renda.

Palavras-chaves: Religião; Pentecostalismo; Redistribuição; Eleições; Brasil. 


\section{Abstract}

According to the leading political economy models, individuals below the median income should vote for redistributive policies in contexts of high inequality. However, there is only weak evidence that the median voter theorem can explain individual electoral behavior. Why do the poor do not vote in candidates who support redistribution? In this study, I address this question considering the effect of religion on the electoral behavior of poor voters. Using Brazil as a case, I argue that Pentecostal leaders act as organizational brokers to mediate the relationship between politicians and low-income voters. These evangelical leaders undermine the political chances of left-wing candidates using moral conservative arguments to mobilize their followers in Pentecostal churches. The evidence from Brazilian presidential elections (2002-2018) shows a better performance of leftists candidates among Catholics and traditional evangelical voters. Conversely, Pentecostal poor voters tend to punish these candidates in the ballots. I also exploit the effect of the religious transition - the rise of Pentecostal evangelicals to the detriment of Catholic Christians - on the electoral support for the Workers Party (PT), the biggest left-wing party in the Brazilian electoral system which won the presidential elections from 2002 to 2014 . The evidence suggests a good electoral performance of PT's candidates in the municipalities where the majority of the population is Catholic, while the electoral support for PT in areas with a high prevalence of Pentecostal Christians tends to be substantively (and statistically) smaller. These results suggest that the religious transition also has important electoral consequences often neglected by literature. As a second step, I leverage on both macro and micro-data to investigate how Pentecostalism affects poor voters' response to income redistribution policies. I show that the increase in welfare induced by the Bolsa Família (PBF), a conditional cash transfer program, produced electoral returns for the PT's candidates only among non-Pentecostal beneficiaries and in areas with a high concentration of Catholics voters. These results are robust and hold across different model specifications and they are still consistent even when confronted with alternative explanatory mechanisms. Overall, the evidence presented in this study helps to explain why low-income voters may not vote for income redistribution in highly unequal contexts.

Keywords: Religion; Pentecostalism; Redistribution; Elections; Brazil. 


\section{Lista de ilustrações}

Figura 1 - Relação entre desigualdade de renda e voto no PT nas eleições presidenciais $(2006-2018) \ldots \ldots \ldots \ldots \ldots \ldots$

Figura 2 - Relação entre pobreza e voto no PT nas eleições presidenciais por filiação religiosa $(2014) \ldots \ldots \ldots 7$

Figura 3 - Peso do eleitorado evangélico pentecostal nas eleições presidenciais brasileiras $(1940-2010) \ldots \ldots \ldots \ldots \ldots$

Figura 4 - Consumo de informação (mídias tradicionais) por filiação religiosa (2014)

Figura 5 - Frequência à igreja e confiança nas lideranças da igreja por filiação religiosa (2014)

Figura 6 - Nível de simpatia pelo petismo por filiação religiosa (2017) . . . . . . 26

Figura 7 - Apoio a pautas morais no Brasil por filiação religiosa (2015) . . . . 29

Figura 8 - Correlação entre a votação do PSDB (2002-2014) e do PSL (2018) nas eleições presidenciais . . . . . . . . . . . . . . . . 32

Figura 9 - Correlação entre religião e voto no PT nas eleições presidenciais (20062018)

Figura 10 - Voto no PT nas eleições presidenciais por filiação religiosa - nível municipal $(2006-2018) \ldots \ldots \ldots \ldots$. . . . . . . . . . . . . .

Figura 11 - Voto no PT nas eleições presidenciais por filiação religiosa - nível individual $(2006-2018) \ldots \ldots \ldots \ldots$. . . . . . . . . . . . . . .

Figura 12 - Voto no PT nas eleições presidenciais de acordo com o crescimento

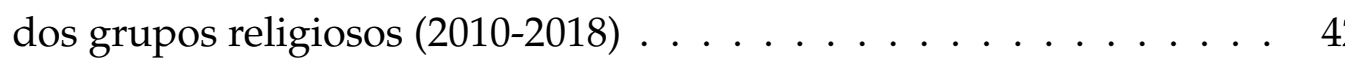


Figura 13 - Exemplo do efeito do pareamento sobre a balanceamento das variáveis de nível municipal . . . . . . . . . . . . . . . . .

Figura 14 - Transição religiosa e voto no PT nas eleições presidenciais (2010-2018) 46

Figura 15 - Voto no PT nas eleições presidenciais por filiação religiosa - eleição

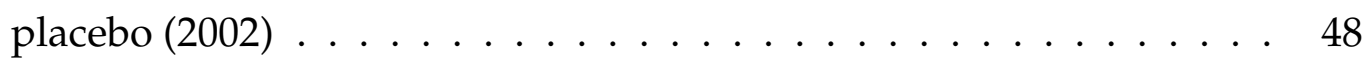

Figura 16 - Preferência por redistribuição por filiação religiosa (2014) . . . . . . . 49

Figura 17 - Mapa de calor da distribuição evangélica pentecostal no Brasil . . . . 53

Figura 18 - Mapa de calor da distribuição evangélica tradicional no Brasil . . . . 55

Figura 19 - Efeitos diretos e indiretos da variável religião sobre o voto no PT nas eleições presidenciais $(2006-2018)$. . . . . . . . . . . . . . . . . . 59

Figura 20 - Distribuição espacial das igrejas ADVEC no estado do Rio de Janeiro (2018)

Figura 21 - Votação do PT nas eleições presidenciais entre os membros da IURD



Figura 22 - Percepção moral dos indivíduos antes (2002) e depois (2004) da conversão ao pentecostalismo . . . . . . . . . . . . . . . . . 76

Figura 23 - Efeito do PBF sobre a votação do PT por filiação religiosa - nível municipal $(2006-2018) \ldots \ldots \ldots \ldots$. . . . . . . . . . . . . 85

Figura 24 - Efeito do PBF sobre a votação do PT por filiação religiosa - nível individual $(2010-2014) \ldots \ldots$. . . . . . . . . . . . 87

Figura 25 - Acesso aos programas sociais por filiação religiosa (2010) . . . . . . . 88

Figura 26 - Avaliação da situação econômica por filiação religiosa (2010) . . . . 90

Figura 27 - Efeito do CS sobre a votação do PS por filiação religiosa (2014) . . . . 96 
Figura 28 - Opinião sobre o aborto em situações extremas por filiação religiosa (2014)

Figura 29 - Preferência por redistribuição dos beneficiários do CS por filiação religiosa $(2014) \ldots \ldots \ldots \ldots \ldots \ldots$

Figura 30 - Percepção da desigualdade dos beneficiários do CS por filiação religiosa $(2014) \ldots \ldots \ldots \ldots \ldots \ldots$

Figura 31 - Aversão à taxação dos beneficiários do CS por filiação religiosa (2014) 102

Figura 32 - Relação entre urbanização, desigualdade e filiação religiosa evangélica pentecostal $(2000$ e 2010$) \ldots \ldots$. . . . . . . . . . . . . . . . . . . . .

Figura 33 - Relação entre urbanização, desigualdade e filiação religiosa evangélica tradicional $(2000$ e 2010$) \ldots \ldots$. . . . . . . . . . . . . 128

Figura 34 - Relação entre urbanização, desigualdade e filiação religiosa católica $(2000$ e 2010$) \ldots \ldots \ldots 12$. . . . . . . . . . . . . . . . . . . . . .

Figura 35 - Distribuição espacial da votação do PSDB nas eleições presidenciais (2006)

Figura 36 - Distribuição espacial da votação do PSDB nas eleições presidenciais (2010)

Figura 37 - Distribuição espacial da votação do PSDB nas eleições presidenciais (2014)

Figura 38 - Distribuição espacial da votação do PSL nas eleições presidenciais (2018)

Figura 39 - Distribuição (\%) católica no território brasileiro (2010) . . . . . . . . . 135

Figura 40 - Distribuição (\%) evangélica pentecostal no território brasileiro (2010) 136

Figura 41 - Distribuição (\%) evangélica tradicional no território brasileiro (2010) 137 
Figura 42 - Mapa de calor da distribuição da religião católica no Brasil . . . . . . 139

Figura 43 - Balanceamento da variável taxa de fertilidade (2000) . . . . . . . . . 141

Figura 44 - Balanceamento da variável taxa de mortalidade (2000) . . . . . . . . 142

Figura 45 - Balanceamento da variável taxa de sobrevida aos 40 anos (2000) . . . 143

Figura 46 - Balanceamento da variável taxa de sobrevida aos 60 anos (2000) . . . 144

Figura 47 - Balanceamento da variável expectativa de anos de estudo (2000) . . 145

Figura 48 - Balanceamento da variável desigualdade de renda (Gini) (2000) . 146

Figura 49 - Balanceamento da variável taxa de pobreza (2000) . . . . . . . . . . . 147

Figura 50 - Balanceamento da variável vulnerabilidade (2000) . . . . . . . . . . 148

Figura 51 - Balanceamento da variável renda per capita dos mais pobres (2000) 149

Figura 52 - Balanceamento da variável população no mercado de trabalho formal

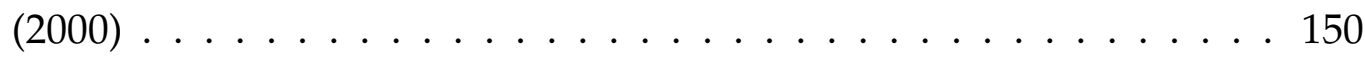

Figura 53 - Balanceamento da variável população economicamente ativa (2000) 151

Figura 54 - Balanceamento da variável tamanho da população (2000) . . . . . . . 152 


\section{Lista de tabelas}

Tabela 1 - Origem das cinco maiores denominações evangélicas pentecostais no Brasil ............................. 19

Tabela 2 - Características sociodemográficas dos indivíduos pentecostais (2010) 23

Tabela 3 - Correlação entre religião e proporção de votos do PT nas eleições presidenciais de $2010 \ldots \ldots \ldots$. . . . . . . . . . . . . 56

Tabela 4 - Descritivas dos dados referentes aos locais de votação (2018) . . . . . 69

Tabela 5 - Correlação entre a distância da igreja e o local de votação e o suporte eleitoral ao PT - Eleições presidencias (2018) . . . . . . . . . . . . . 71

Tabela 6 - Lista dos municípios com transição religiosa completa em 2010 . . . 153

Tabela 7 - Descritivas das variáveis de nível municipal (2000 e 2010) . . . . . . . 155

Tabela 8 - Votação do PT (2002-2018) e alocação do PBF nos municípios brasilei-



Tabela 9 - Descritivas das variáveis do ESEB (2010) . . . . . . . . . . . . . 157

Tabela 10 - Descritivas das variáveis do ESEB (2014) . . . . . . . . . . . . . 158

Tabela 11 - Descritivas das variáveis do Latinobarômetro (2015) . . . . . . . . . . 159

Tabela 12 - Descritivas das variáveis do LAPOP (2008) . . . . . . . . . . . . . 160

Tabela 13 - Descritivas das variáveis do LAPOP (2014) . . . . . . . . . . . . . . 161

Tabela 14 - Descritivas das variáveis do LAPOP (2017) . . . . . . . . . . . . 162

Tabela 15 - Descritivas das variáveis do Datafolha (2018) . . . . . . . . . . . . 163

Tabela 16 - Descritivas das variáveis dos dados em painel (2002-2004) . . . . . . 164

Tabela 17 - Relação entre desigualdade de renda e voto no PT nas eleições presidenciais $(2006-2018) \ldots \ldots \ldots$. . . . . . . . . . . . . . . . . . . . . 
Tabela 18 - Relação entre pobreza e voto no PT nas eleições presidenciais por filiação religiosa $(2014) \ldots \ldots$. . . . . . . . . . . . . . 166

Tabela 19 - Consumo de informação (mídias tradicionais) por filiação religiosa



Tabela 20 - Consumo de informação (mídias tradicionais) por filiação religiosa (2014) - continuação . . . . . . . . . . . . . . . . . 168

Tabela 21 - Frequência à igreja e confiança nas lideranças da igreja por filiação religiosa $(2014) \ldots \ldots$. . . . . . . . . . . . . . . . 169

Tabela 22 - Nível de simpatia pelo petismo por filiação religiosa (2017) . . . . . . 170

Tabela 23 - Apoio a pautas morais por filiação religiosa (2015) . . . . . . . . . . . 171

Tabela 24 - Voto no PT nas eleições presidenciais por filiação religiosa - nível municipal $(2006-2018) \quad \ldots \ldots \ldots 17 \ldots \ldots \ldots$

Tabela 25 - Voto no PT nas eleições presidenciais por filiação religiosa - nível municipal (2006-2018) - continuação . . . . . . . . . . . . . 173

Tabela 26 - Voto no PT nas eleições presidenciais por filiação religiosa - nível individual (2006) f . . . . . . . . . . . . . . . . 174

Tabela 27 - Voto no PT nas eleições presidenciais por filiação religiosa - nível individual $(2010$ e 2014$) \ldots \ldots$. . . . . . . . . . . . . . . 175

Tabela 28 - Voto no PT nas eleições presidenciais por filiação religiosa - nível individual $(2018) \ldots \ldots \ldots \ldots$. . . . . . . . . . . . . . . . . . . . . . .

Tabela 29 - Voto para presidente de acordo com o crescimento dos grupos religio$\operatorname{sos}(2010$ e 2014) . . . . . . . . . . . . . . . . . . . 177

Tabela 30 - Voto no PT nas eleições presidenciais de acordo com o crescimento dos grupos religiosos $(2018) \ldots \ldots$. . . . . . . . . . . 178 
Tabela 31 - Transição religiosa e voto no PT nas eleições presidenciais (2010-2018)

- Municípios com maioria evangélica pentecostal . . . . . . . . . . . 179

Tabela 32 - Transição religiosa e voto no PT nas eleições presidenciais (2010-2018)

- Municípios com maioria evangélica tradicional . . . . . . . . . . 179

Tabela 33 - Voto no PT nas eleições presidenciais por filiação religiosa - eleição placebo $(2002) \ldots \ldots \ldots$. . . . . . . . . . . . . . . . . . . . . . . . . . .

Tabela 34 - Preferência por redistribuição por filiação religiosa (2014) . . . . . . 181

Tabela 35 - Efeitos de vizinhança da variável religião sobre a votação do PT (2006) 182

Tabela 36 - Efeitos de vizinhança da variável religião sobre a votação do PT (2010)183

Tabela 37 - Efeitos de vizinhança da variável religião sobre a votação do PT (2014)184

Tabela 38 - Efeitos de vizinhança da variável religião sobre a votação do PT (2018)185

Tabela 39 - Votação do PT nas eleições presidenciais entre os membros da IURD $(2010$ e 2014$) \ldots \ldots \ldots$. . . . . . . . . . . . . . . . 186

Tabela 40 - Percepção moral dos indivíduos antes (2002) e depois (2004) da conversão ao pentecostalismo . . . . . . . . . . . . . . . . . 187

Tabela 41 - Efeito do PBF sobre a votação do PT por filiação religiosa - nível municipal (2006) . . . . . . . . . . . . . . . . . 188

Tabela 42 - Efeito do PBF sobre a votação do PT por filiação religiosa - nível municipal $(2010) \ldots \ldots$. . . . . . . . . . . . . . . . 189

Tabela 43 - Efeito do PBF sobre a votação do PT por filiação religiosa - nível municipal $(2014) \ldots \ldots \ldots$. . . . . . . . . . . . . . . 190

Tabela 44 - Efeito do PBF sobre a votação do PT por filiação religiosa - nível municipal (2018) 
Tabela 45 - Efeito do PBF sobre a votação do PT por filiação religiosa - nível individual $(2010) \quad \ldots \ldots \ldots$

Tabela 46 - Efeito do PBF sobre a votação do PT por filiação religiosa - nível individual $(2014) \ldots \ldots$. . . . . . . . . . . . . . . 193

Tabela 47 - Acesso aos programas sociais por filiação religiosa - Bolsa Família $(2010) \ldots \ldots \ldots \ldots \ldots \ldots \ldots$

Tabela 48 - Acesso aos programas sociais por filiação religiosa - Luz para Todos

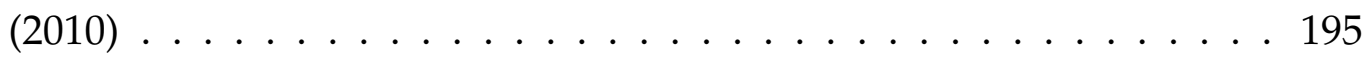

Tabela 49 - Acesso aos programas sociais por filiação religiosa - Minha Casa, Minha Vida (2010) . . . . . . . . . . . . . . . . . . 196

Tabela 50 - Avaliação da situação econômica por filiação religiosa - nível individual $(2010) \ldots \ldots \ldots$. . . . . . . . . . . . . . . . . 197

Tabela 51 - Efeito do CS sobre a votação do PS por filiação religiosa (2014) . . . 198

Tabela 52 - Opinião sobre o aborto em situações extremas por filiação religiosa (2014)

Tabela 53 - Preferência por redistribuição dos beneficiários do CS por filiação religiosa $(2014) \ldots \ldots . \ldots \ldots$. . . . . . . . . . . . . . . . . . . . . .

Tabela 54 - Percepção da desigualdade dos beneficiários do CS por filiação religiosa $(2014) \ldots \ldots \ldots \ldots \ldots \ldots$

Tabela 55 - Aversão à taxação dos beneficiários do CS por filiação religiosa (2014) 202 



\title{
Lista de abreviaturas e siglas
}

\author{
ADVEC Assembleia de Deus Vitória em Cristo \\ ATET Average Treatment Effect on treatement group \\ CEP Código de Endereçamento Postal \\ CGADB Convenção Geral das Assembleias de Deus no Brasil \\ CONAMAD Convenção Nacional das Assembleias de Deus \\ CPF Cadastro de Pessoa Física \\ CS Chile Solidário \\ ESEB Estudo Eleitoral Brasileiro \\ EUA Estados Unidos da América \\ IBGE Instituto Brasileiro de Geografia e Estatística \\ IC Intervalo de Confiança \\ IDHM Índice de Desenvolvimento Humano Municipal \\ IURD Igreja Universal do Reino de Deus \\ LAPOP Latin American Public Opinion Project \\ LPT Luz para Todos \\ MAE Modelos de Autocorrelação Espacial \\ MDS Ministério do Desenvolvimento Social
}




\begin{tabular}{ll} 
MCMV & Minha Casa, Minha Vida \\
MBF & Minas Gerais \\
PEA & Programa Bolsa Família \\
PIB & População Economicamente Ativa \\
PRN & Partido da Reconstrução Nacional \\
PS & Partido Socialista \\
PSDB & Partido da Social Democracia Brasileira \\
PSL & Partido Social Liberal \\
PSOL & Partido Socialismo e Liberdade \\
PT & Partido dos Trabalhadores \\
PSE & Partido Trabalhista Cristão \\
Prouni & Programa Universidade para Todos \\
\hline
\end{tabular}




\section{Sumário}

INTRODUÇÃo $\ldots \ldots \ldots \ldots \ldots \ldots \ldots \ldots \ldots$

1 O MOVIMENTO PENTECOSTAL NO BRASIL $\ldots \ldots \ldots \ldots$

$1.1 \quad$ Um fenômeno chamado pentecostalismo $\ldots \ldots \ldots \ldots$

1.2 Quem são os evangélicos pentecostais brasileiros? . . . . . . 22

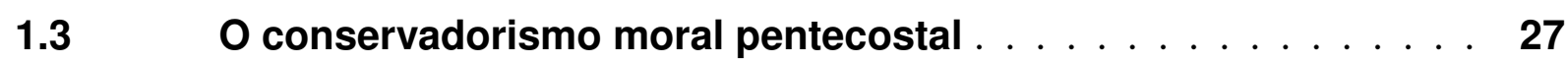

2 RELIGIÃO E VOTO NO BRASIL $\ldots \ldots \ldots \ldots \ldots \ldots$

$2.1 \quad$ A religião como um preditor do voto $\ldots \ldots \ldots \ldots \ldots$

$2.2 \quad$ Religião e voto: evidência de nível municipal . . . . . . . . . . 34

$2.3 \quad$ Filiação religiosa e voto: evidência de nível individual $\ldots \ldots$. . . 37

2.4 Transição religiosa e comportamento eleitoral . . . . . . . . . . 40

$2.5 \quad$ Mecanismos alternativos $\ldots \ldots \ldots \ldots \ldots \ldots$

3 A RELIGIÃO E SEUS EFEITOS DE VIZINHANÇA $\ldots \ldots \ldots \ldots$

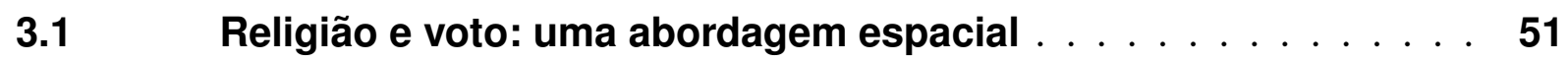

3.2 A religião e seus padrões de concentração espacial . . . . . . 52

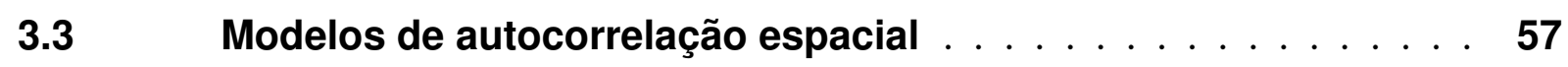

$3.4 \quad$ Efeitos de vizinhança da variável religião $\ldots \ldots \ldots \ldots$

4 MORALISMO COMO ESTRATÉGIA ELEITORAL . . . . . . . 61

4.1 Brasil acima de tudo, Deus acima de todos . . . . . . . 61

$4.2 \quad$ Os pastores como brokers $\ldots \ldots \ldots \ldots \ldots \ldots$

4.3 A mobilização eleitoral nas igrejas pentecostais . . . . . . . . . 65 
$4.4 \quad$ Efeito do pastor ou falácia ecológica? . . . . . . . . . . . 72

$5 \quad$ PENTECOSTALISMO E POLÍtICAS PÚBlICAS $\ldots 79$

$5.1 \quad$ Bolsa Família e voto econômico . . . . . . . . . . . . 79

$5.2 \quad$ Religião como variável interveniente . . . . . . . . . . . . 80

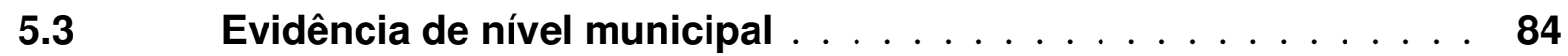

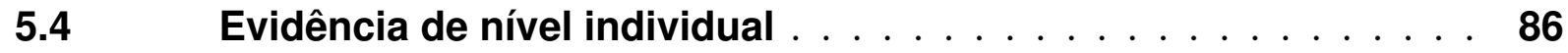

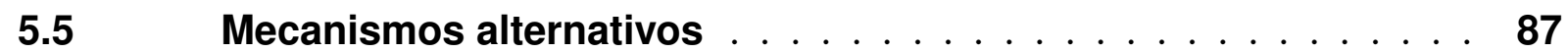

$5.6 \quad$ O Brasil em perspectiva comparada $\ldots \ldots \ldots \ldots$

$5.7 \quad$ Transferência condicional de renda: Chile solidario _ . . . . . . 92

$5.8 \quad$ Hipóteses $\ldots \ldots \ldots \ldots \ldots$

$5.9 \quad$ Políticas redistributivas e voto no Chile . . . . . . . . . . . . 94

$5.10 \quad$ Mecanismo: o conservadorismo moral pentecostal . . . . . . . 97



CONCLUSÃo . . . . . . . . . . . . . . . . . . 105

REFERÊNCIAS . . . . . . . . . . . . . . . . . . 113

$\begin{array}{ll}\text { APÊNDICES } & 125\end{array}$

APÊNDICE A - URBANIZAÇÃO, DESIGUALDADE E FILIAÇÃO RELIGIOSA . . . . . . . . . . . . . . . . . 127

APÊNDICE B - VOTO NO TERRITÓRIO BRASILEIRO . . . . . . . 131

APÊNDICE C - GRANDES RELIGIÕES CRISTÃS NO TERRITÓRIO BRASILEIRO . . . . . . . . . . . . . . . . 135 
APÊNDICE D - MAPA DE CALOR DA RELIGIÃO CATÓLICA . . . 139

APÊNDICE E - BALANCEAMENTO DAS COVARIÁVEIS $\ldots \ldots 141$

APÊNDICE F - MUNICÍPIOS BRASILEIROS COM MAIORIA EVAN-

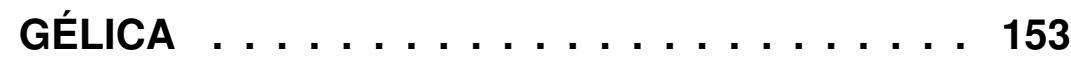

APÊNDICE G - ESTATÍSTICAS DESCRITIVAS . . . . . . 155

APÊNDICE H - TABELAS DE REGRESSÃO . . . . . . . . 165

ANEXOS

ANEXO A - A OPINIÃO DE EDIR MACEDO (IURD) SOBRE A PRÁTICA DO ABORTO . . . . . . . . . . . . . 205 


\section{Introdução}

\section{Motivação}

A onda de redemocratização que atingiu a América Latina a partir dos anos 1970 produziu grande expectativa de mudanças de ordem econômica e social. Dentre elas, a de que a adoção de eleições limpas e justas e a extensão do sufrágio universal produziriam pressão por redistribuição de renda. Sendo os pobres a maioria do eleitorado e os políticos dependentes do apoio da maioria para vencer eleições, a redução da desigualdade seria uma consequência natural do aumento da competição eleitoral. A expectativa não se confirmou. Passadas algumas décadas, a América Latina consolidou sua posição de região com pior distribuição de renda no mundo (ALVAREDO et al., 2018).

A eleição de Luiz Inácio Lula da Silva (Partido dos Trabalhadores, PT), bem como a vitória de outros partidos de esquerda com propostas redistributivas em vários países da América do Sul nos anos 2000, naquilo que ficou conhecido como "Maré Rosa" (WEYLAND; MADRID; HUNTER, 2010) ou período "pós-neoliberal"(GRUGEL; RIGGIROZZI, 2012), parecia confirmar a expectativa teórica de que a porção mais pobre do eleitorado tenderia a votar por redistribuição ${ }^{1}$. No entanto, a eleição de governos de esquerda na região contrasta com o sucesso eleitoral de candidatos com plataformas conservadoras ou de políticos outsiders com discursos liberalizantes e anti-redistribuição.

1 O processo de crescimento eleitoral dos partidos de esquerda foi, em grande medida, determinado pelo fracasso das políticas econômicas implementadas pelas elites políticas que emergiram dos governos militares na América Latina (HUBER; STEPHENS, 2012). Com forte pressão inflacionária e diante de um fraco desempenho econômico, o período imediatamente posterior à redemocratização foi marcado por aumento da dívida pública, déficit fiscal e consequente agravamento das desigualdades sociais em vários países da região (CAMPELLO, 2014; WIBBELS; ROBERTS, 2010). 
No período recente, destaca-se a eleição de Maurício Macri (Argentina, 2014), Sebastian Piñera (Chile, 2017), Ivan Duque (Colômbia, 2018) e Jair Bolsonaro (Brasil, 2018). Este novo ciclo de sucesso eleitoral de candidatos à direita do espectro ideológico reabriu o debate sobre a "racionalidade" do voto dos pobres na América Latina. Por que uma parcela substantiva do eleitorado de baixa renda em países com alta desigualdade vota em candidatos que não priorizam propostas redistributivas?

\section{Por que os pobres não votam por redistribuição?}

Indivíduos ricos possuem poucos incentivos para votar por redistribuição porque são menos dependentes do Estado para acessar serviços e avessos à ideia de pagar mais impostos (MELTZER; RICHARD, 1981)². No entanto, os motivos que levam eleitores pobres - aqueles que dependem da transferência de renda para experimentar ascensão social - a não votarem por redistribuição ainda desafiam nossa compreensão sobre a realidade social.

Uma ideia central na teoria da representação democrática é que os políticos são responsivos aos eleitores. Isso significa que, uma vez eleitos, os políticos deveriam implementar políticas que espelham as preferências do eleitorado (PRZEWORSKI; STOKES; MANIN, 1999). Como as eleições tendem a ser decididas pelos eleitores sem forte identificação partidária, os políticos tenderiam a implementar políticas próximas das preferências desse grupo (BASSETTO; BENHABIB, 2006). Em países com alta desigualdade, este eleitor que decide eleições (eleitor mediano) tende a ser deslocado para a esquerda do espectro ideológico, dado que a maior parte da população está

2 Indivíduos ricos podem apoiar a ideia de mais redistribuição de renda para atenuar as externalidades negativas associadas à concentração da renda (RUEDA; STEGMUELLER, 2016) ou quando esperam perder renda no futuro (IVERSEN; SOSKICE, 2001). 
abaixo da mediana de renda. A consequência lógica desse movimento seria o aumento da pressão por redistribuição em países com alta desigualdade (ACEMOGLU et al., 2015).

Figura 1 - Relação entre desigualdade de renda e voto no PT nas eleições presidenciais (2006-2018)

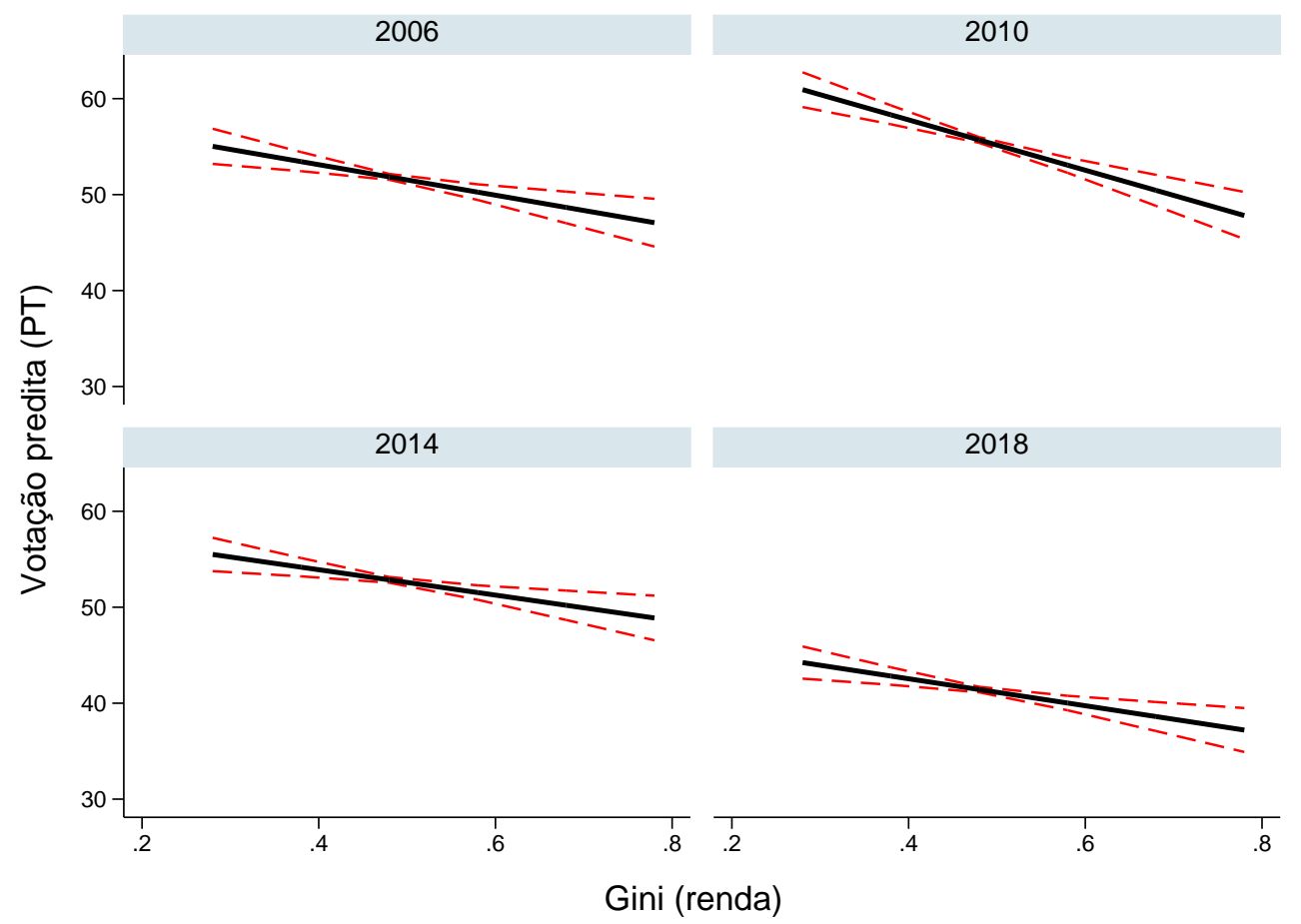

Nota: elaborado pelo autor a partir dos dados do Tribunal Superior eleitoral (TSE) e do Instituto Brasileiro de Geografia e Estatística (IBGE). O eixo Y representa a votação predita do PT no segundo turno das eleições presidenciais brasileiras (2006-2018). O eixo X representa o nível de desigualdade de renda nos municípios brasileiros medida pelo coeficiente de Gini (valores próximos de 0 indicam baixa desigualdade, enquanto valores próximos de 1 indicam alta desigualdade). A unidade de análise é o município ( $\mathrm{N}=$ $5,565)$ e um modelo de mínimos quadrados ordinários foi estimado para cada ano eleitoral utilizando os seguintes controles: taxa de analfabetismo, taxa de pobreza, renda per capita, taxa de desocupação, índice de desenvolvimento humano municipal (IDHM), número de beneficiários do Bolsa Família e uma variável que indica a região de cada município. Os erros padrões são clusterizados no nível do município.

As evidências, todavia, desafiam essa formulação. Tomemos o Brasil como exemplo para ilustrar a correlação negativa entre desigualdade e pressão eleitoral por redistribuição. A figura ${ }^{3} 1$ mostra a relação entre desigualdade de renda, medida pelo

3 Neste trabalho, sempre que possível, as análises econométricas serão reportadas na forma de gráficos para facilitar a interpretação dos resultados. No entanto, as tabelas de regressão com todos os coeficientes e estatísticas de ajuste podem ser consultadas no Apêndice $\mathrm{H}$ de acordo com a ordem em que aparecem no texto. As estatísticas descritivas das variáveis de todos os bancos de dados utilizados neste trabalho são reportadas no Apêndice G. 
coeficiente de Gini, e a votação do PT, o partido de esquerda que esteve entre os dois primeiros colocados em todas as eleições presidenciais desde a redemocratização ${ }^{4}$. Os dados, desagregados por município para captar a variação da desigualdade de renda no território brasileiro, indicam uma menor quantidade de votos preditos para o PT nas eleições presidenciais à medida que a desigualdade de renda aumenta (IC de 99\%). Estas evidências de nível municipal parecem não corroborar a tese de que os potenciais beneficiários da redistribuição tenderiam a votar em candidatos à esquerda do espectro ideológico.

De fato, a análise do caso brasileiro apenas reforça um padrão recorrente nas democracias contemporâneas: desigualdade de renda não significa necessariamente mais pressão por redistribuição. Curiosamente, a demanda por redistribuição de renda tende a ser menor nos contextos com maior desigualdade (ALESINA; GIULIANO, 2011).

\section{Argumento: como o pentecostalismo distrai os pobres?}

As evidências que sugerem menor suporte à redistribuição em contextos com maior desigualdade colocaram em xeque a capacidade preditiva da teoria do eleitor mediano (ALESINA; GLAESER; GLAESER, 2004; LUPU; PONTUSSON, 2011), abrindo espaço para teorias alternativas que visam explicar a aparente contradição entre as expectativas da teoria do eleitor mediano e o comportamento eleitoral dos indivíduos de baixa renda.

Por exemplo, a teoria do aprendizado social proposta por Piketty (1995) sugere que a percepção de mobilidade social afeta a preferência individual por redistribuição.

\footnotetext{
4 Para uma revisão sobre a trajetória do PT na política partidária brasileira, ver Reis (2014).
} 
$\mathrm{O}$ autor argumenta que aqueles que percebem ascensão social tendem a se tornar mais tolerantes à desigualdade. Isso ocorre porque esses indivíduos associam suas experiências de mobilidade com valores relacionados ao esforço e à sorte. Portanto, indivíduos pobres que experimentam ascensão tendem a desaprovar políticas que têm como objetivo promover redistribuição de renda, de modo que os partidos de esquerda enfrentam dificuldades para angariar apoio neste grupo de eleitores.

O modelo formulado por Benabou e Ok (2001) também considera a expectativa de ascensão social como um fator determinante para a formação das preferências relacionadas à redistribuição. Estes autores argumentam que aqueles que possuem uma renda abaixo da mediana, mas esperam, em breve, enriquecer além da mediana, tendem a não apoiar a intervenção do Estado para redistribuir renda. Os indivíduos recém-promovidos à classe média esperam com isso não ter que arcar com o pagamento de mais impostos para que o governo redistribua renda e promova a ascensão social de outros.

Uma segunda linha de argumentação foca na falsa percepção de riqueza dos eleitores pobres. A principal premissa do modelo derivado da teoria do eleitor mediano proposto por Meltzer e Richard (1981) é que os indivíduos sabem se posicionar na escala de distribuição de rendimentos. Assim, indivíduos abaixo da mediana de rendimentos, cientes da sua condição desfavorável e com expectativa de ascensão social, deveriam votar em partidos de esquerda, aqueles com propostas claramente redistributivas. Da mesma forma, indivíduos acima da mediana de rendimentos deveriam votar em partidos com propostas não redistributivas a fim de evitar o aumento de impostos. No entanto, como mostram Hauser e Norton (2017), apenas raramente os indivíduos conseguem identificar sua real posição na distribuição de rendimentos. Além disso, 
a preferência por redistribuição dos indivíduos é correlacionada com a percepção de renda dos mesmos, mais do que com a renda real (GIMPELSON; TREISMAN, 2018). Como consequência, os indivíduos pobres passam a perceber mais desigualdade apenas quando informados sobre sua real condição de pobreza (CRUCES; PEREZ-TRUGLIA; TETAZ, 2013; BUBLITZ, 2017).

Uma terceira linha interpretativa mostra como a religião pode distrair os pobres e reduzir a pressão por redistribuição. O trabalho seminal publicado por Scheve e Stasavage (2006) mostra que os pobres que frequentam templos religiosos abdicam de serviços oferecidos pelo Estado porque possuem acesso a uma rede alternativa de proteção social oferecida pelas igrejas. Nesta rede, os fiéis podem receber suporte material e psicológico, bem como ter acesso privilegiado a oferta de trabalho e oportunidades de pequenos negócios.

As análises que se seguiram encontraram suporte para o referido argumento, embora explorem mecanismos alternativos para o intrigante comportamento eleitoral de pobres religiosos. Por exemplo, Stegmueller (2013) mostra que eleitores religiosos são mais conservadores do que indivíduos sem religião. E esse maior conservadorismo explicaria a opção do primeiro grupo por partidos de direita, ainda que isso possa significar votar por menos redistribuição. Na mesma direção, outros trabalhos sugerem que a correlação entre pobreza e apoio à redistribuição torna-se mais fraca quando a dimensão moral se correlaciona com a renda dos indivíduos (DELAO; RODDEN, 2008; HUBER; STANIG, 2011; JORDAN, 2014).

Uma limitação dessas análises é tratar o grupo "religiosos" como uma categoria homogênea. No Brasil, por exemplo, católicos e evangélicos se diferenciam em diversas dimensões sociais e econômicas (CAMPOS, 2008; MARIANO, 1999; FRESTON, 
2004; ALMEIDA, 2017). Além disso, o termo "evangélico" abarca heterogeneidades importantes e designa tanto as igrejas protestantes tradicionais (Luterana, Presbiteriana, Congregacional, Anglicana, Metodista e Batista) $)^{5}$ como as pentecostais (Congregação Cristã do Brasil, Assembleia de Deus, Evangelho Quadrangular, Brasil para Cristo, Deus é Amor, Igreja Renascer, Igreja Cristã de Nova Vida, Igreja Universal do Reino de Deus, etc.).

Figura 2 - Relação entre pobreza e voto no PT nas eleições presidenciais por filiação religiosa (2014)

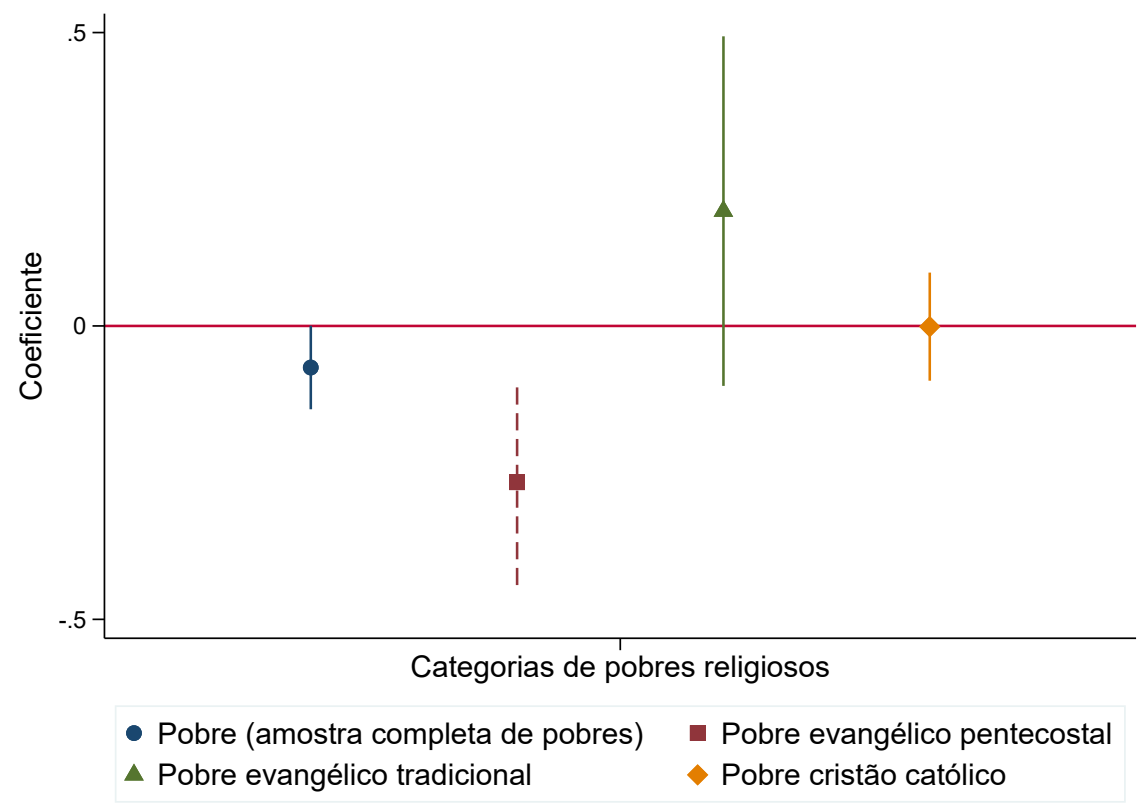

Nota: elaborado pelo autor a partir dos dados do Estudo Eleitoral Brasileiro (ESEB, 2014). A unidade de análise é o indivíduo $(\mathrm{N}=3,049)$. São considerados pobres os indivíduos com renda total familiar até dois salários mínimos. Os modelos de regressão logística apresentados na figura 2 foram ajustados com erros padrões robustos utilizando os seguintes controles: idade, sexo, raça, escolaridade, status ocupacional, percepção da economia, preferência partidária, preferência por redistribuição, preferência por taxação e região dos indivíduos.

A visão de mundo dos indivíduos é explicada, em boa medida, por suas crenças.

A religião - ou, mais precisamente, suas variações - afeta o modo como os indivíduos

5 Os evangélicos tradicionais são também conhecidos como evangélicos históricos ou de missão por terem sido os primeiros a ocupar o território brasileiro. Emprego a terminologia "evangélicos tradicionais" por entender que este grupo de igrejas adota como base uma teologia mais próxima daquela advogada por alguns dos pais da reforma protestante, como Lutero, Calvino e Zwingli (LINDBERG, 2017). 
fazem escolhas eleitorais. Por exemplo, a presunção de que pobres deveriam votar por redistribuição ignora os possíveis efeitos da religião sobre as preferências individuais. A figura 2 ilustra esse ponto a partir da correlação entre renda individual e voto no PT, o partido de esquerda mais competitivo, com maior capilaridade nos municípios brasileiros, maior representação no Congresso Nacional e que logrou sucesso eleitoral em quatro eleições presidenciais consecutivas entre 2002 e 2014.

Mantidos outros fatores, como idade, sexo, raça e nível educacional constantes, indivíduos pobres, aqui tratados como aqueles com renda total familiar até dois salários mínimos, tendem a rejeitar o PT nas urnas (IC de 95\%). Essa aparente contradição é explicada pelo peso dos indivíduos de filiação pentecostal entre os eleitores de baixa renda, como pode ser visto na figura 2. Nas eleições presidenciais de 2014, a probabilidade de um eleitor pobre pentecostal votar no PT foi 51\% menor (IC de 99\%) na comparação com pobres de outros grupos religiosos. Os coeficientes não estatisticamente significantes de católicos e evangélicos tradicionais sugerem menor rejeição eleitoral ao PT entre os eleitores pobres desses grupos.

Nesta tese, argumento que ao mobilizar os fiés contra os partidos que ameaçam seus valores morais, as lideranças pentecostais criam incentivos para que os eleitores de baixa renda, maioria nesse grupo evangélico, votem contra os partidos de esquerda, diminuindo a pressāo eleitoral por redistribuição que poderia emergir dos estratos mais pobres da população. Para tanto, reconstruo parte da trajetória eleitoral do PT nas eleições presidenciais brasileiras para ilustrar o efeito da variável religião sobre o comportamento eleitoral de diferentes grupos religiosos no Brasil. Entre 1989 e 2018, o PT não esteve no segundo turno das eleições presidenciais apenas em 1998, quando o candidato Fernando Henrique Cardoso (Partido da Social Democracia Brasileira, PSDB) 
foi eleito em primeiro turno com $53 \%$ dos votos válidos. No entanto, os candidatos petistas jamais contaram com apoio majoritário do segmento evangélico pentecostal.

Na versão clássica da teologia protestante, a salvação é vista como um resultado da misericórdia de Deus, que enviou seu filho, Jesus, para morrer pelos pecados de seus filhos. Desse modo, a santificação permite aproximar-se de Deus, mas não garante a salvação que, em última instância, é resultado da graça divina (GEORGE, 1993). A teologia desenvolvida no seio do pentecostalismo altera essa lógica: a salvação passa a ser uma consequência da busca constante da correção dos atos individuais e da purificação da alma (MATOS, 2006). Por isso, o convervadorismo moral tende a ser mais forte entre os evangélicos pentecostais.

A base doutrinária pentecostal estimula um comportamento individual fundado em um proselitismo de cunho fortemente moralizante. Se a graça e o poder de Deus são revelados apenas àqueles que atingem um certo nível de santidade, todos os não-crentes, também chamados de ímpios ${ }^{6}$, são necessariamente pecadores e se encontram distantes de Deus. Desse modo, os adeptos do pentecostalismo se veem, não apenas como guardiões de sua própria santidade, mas também corresponsáveis pela manutenção do padrão moral da sociedade como um todo (SOUZA; MAGALHÃES, 2002).

\section{Os pastores como cabos eleitorais (brokers)}

Em seu último texto publicado na revista Novos Estudos, o sociólogo da religião Antônio Flávio Pierucci (2011) afirmou o seguinte: "Não lembro, e certamente ninguém há de lembrar, de uma campanha eleitoral em que a intromissão da religião tenha sido tão grande e ido tão longe como na eleição presidencial de 2010 para a sucessão de

\footnotetext{
6 Aqueles que não têm fé ou que têm desprezo pela religião.
} 
Lula"(p.5). Na continuidade de sua análise, Pierucci (2011) afirma que "os pastores evangélicos ficaram mais escolados e autoconfiantes para explorar o conservadorismo dos membros de suas igrejas"(p. 6). Apesar disso, diante da vitória da candidata de esquerda no segundo turno, Dilma Rousseff (PT), o autor conclui seu ensaio afirmando que o "moralismo religioso"foi desmoralizado nas eleições de 2010, o que poderia sugerir a pouca efetividade do engajamento eleitoral das lideranças evangélicas.

De fato, o argumento da "não influência"dos pastores evangélicos sobre seus liderados é recorrente na literatura. Freston (2006) sustenta que, apesar dos esforços dos pastores para influenciar a percepção política dos membros de suas igrejas, não existe nenhuma garantia de alinhamento no momento do voto. Prandi, Santos e Bonato (2019) chegam a ir mais longe ao afirmar que grande parte dos evangélicos não segue as recomendações de suas lideranças. De acordo com estes autores, os fiés desse grupo "destoam daquela imagem de rebanho eleitoral facilmente manejável e influenciável pelas pregações proferidas nos cultos"(p.57). Smith (2019) caminha na mesma direção ao sugerir que "a maior parte dos eleitores adota normas democráticas seculares que os levam a resistir a certos tipos de influência das liderenças evangélicas"(p. 6).

Essa interpretação pode ser resultante da não consideração da heterogeneidade existente no interior da categoria "evangélicos". O trabalho de Smith (2019), por exemplo, assume que "evangélicos tradicionais e pentecostais tendem a pensar e agir de modo muito semelhante"(p.12), o que justificaria agrupar as duas correntes cristãs na mesma categoria analítica. No entanto, evangélicos pentecostais e evangélicos tradicionais diferem entre si. O conservadorismo moral é um fenômeno mais saliente entre os evangélicos pentecostais. As liderenças deste segmento evangélico também tendem a ser mais engajadas e participam ativamente das eleições mobilizando seus fiés em torno 
de uma agenda eleitoral comum.

Como argumento neste trabalho, os pastores pentecostais se diferenciam de outras lideranças religiosas atuando como cabos eleitorais (brokers) e mediando a relação entre candidatos e eleitores de baixa renda. Essas lideranças utilizam elementos bíblicos e fundamentação teológica para alterar a percepção moral de seus fiéis e colocá-los em oposição aos atores políticos com pautas progressistas. Como consequência, os partidos de esquerda tendem a ser punidos pelos eleitores pentecostais pobres por defenderem uma agenda de costumes mais flexível, como a descriminalização das drogas e do aborto e a extensão do direito de matrimônio para casais homoafetivos.

\section{Premissas fundamentais}

Esta tese se assenta em três premissas fundamentais. A primeira delas é que a religião tende a ser uma identidade eleitoral dominante (GRZYMALA-BUSSE, 2012). Em geral, as religiões prescrevem um conjunto de valores e doutrinas que afetam todas as dimensões da vida, inclusive a política. Diferentemente de outras identidades, como renda, raça e gênero, a identidade religiosa consegue compelir os indivíduos a se comportarem de uma determinada forma graças ao seu apelo divino e sobrenatural (STARK; FINKE, 2000). Por isso, no momento eleitoral, os indivíduos podem anular outras identidades em favor da identidade religiosa (WALD; SILVERMAN; FRIDY, 2005). Além disso, pela sua própria natureza moral baseada em regras e preceitos, a religião demarca de forma mais clara a visão de mundo dos indivíduos e reduz as heterogeneidades intragrupo, aumentando os incentivos para que os partidos explorem pautas identitárias religiosas no momento eleitoral (HUBER, 2017). 
A segunda premissa é que os eleitores são capazes de identificar programas eleitorais com propostas redistributivas. Essa premissa não depende da presunção de que os indivíduos possuem informação completa para escolher seus candidatos, nem que os indivíduos têm forte identificação partidária. Assumo apenas que os eleitores apresentam algum nível de sofisticação política - capacidade dos eleitores para comparar e diferenciar os candidatos de acordo com suas propostas eleitorais - para basear suas decisões.

O processo eleitoral cria incentivos para a disseminação de informação, estimulando os partidos a converterem pautas complexas em discussões mais acessíveis para o eleitorado. Por exemplo, a discussão de políticas de redistribuição e combate à pobreza pode ser simplificada e apresentada nos termos da manutenção ou não do Programa Bolsa Família. Um tema de saúde pública como o aborto pode ser reduzido a uma discussão entre aqueles que estão a favor ou contra a vida. Por isso, mesmo eleitores pouco sofisticados do ponto de vista político são capazes de escolher os candidatos que estão mais próximos das suas preferências (IZUMI, 2019).

A terceira premissa é que os partidos de esquerda têm interesse em implementar políticas pró-redistribuição porque representam uma agenda de interesses organizados em torno dessa pauta. Sindicatos de trabalhadores atuam em favor do aumento do gasto social para expandir o portfólio de benefícios de seus associados. Da mesma forma, movimentos sociais pró-redistribuição tendem a se articular em favor da expansão dos direitos das minorias e/ou daqueles afetados pela distribuição desigual de rendimentos. Portanto, a eleição de partidos de esquerda se viabiliza apenas quando os candidatos destes partidos se comprometem com a redistribuição. Uma vez eleitos, governos compostos por partidos de esquerda têm interesse em implementar uma 
agenda redistribuitiva para manter sua base de apoio e conquistar mais votos entre os eleitores de baixa renda.

Por isso, os partidos de esquerda são os atores políticos que pautam o tema da redistribuição nas arenas formais de discussão política (MCCARTY; POOLE; ROSENTHAL, 2016) e aqueles historicamente engajados em programas de combate à pobreza e inclusão social (ESPING-ANDERSEN, 2017). Neste sentido, Huber e Stephens (2012) mostram que a ascensão de governos de esquerda decorrente do processo de redemocratização e do aumento da competição eleitoral foi fundamental para o aumento do gasto social com educação e saúde na América Latina. Não por acaso, a desigualdade de renda tende a aumentar após sucessivos governos de partidos de direita (BRADY; LEICHT, 2008) e a regredir sob governos de esquerda (HUBER; RAGIN; STEPHENS, 1993).

\section{Plano da Tese}

Neste trabalho, busco explicar por que pobres não votam em propostas eleitorais redistributivas. Abordando o caso brasileiro, argumento que o pentecostalismo reduz a pressāo eleitoral por redistribuição ao fomentar a rejeição aos partidos de esquerda entre os eleitores de baixa renda. Para tanto, além desta introdução e da conclusão, esta tese é estruturada em mais cinco capítulos.

No capítulo 1, apresento um retrato histórico do pentecostalismo brasileiro e discuto as bases teológicas que iluminam a conduta moral de seus adeptos. Mostro como os evangélicos pentecostais se diferenciam de outras religiões cristãs em uma série de dimensões sociais, mas sobretudo nos níveis de conservadorismo moral, afetando as 
preferências políticas dos indivíduos filiados a este grupo.

No capítulo 2, utilizo resultados eleitorais desagregados por município para estimar o efeito da variável religião sobre o suporte eleitoral ao PT, o partido de esquerda brasileiro mais competitivo que encampou a agenda de redistribuição nas disputas para presidente entre 2002 e 2018. Os resultados indicam uma redução do suporte eleitoral ao PT à medida que cresce a proporção de indivíduos que se declaram evangélicos, mas esse resultado é puxado pelo comportamento eleitoral dos evangélicos pentecostais. Eleitores pobres católicos, por seu turno, tendem a votar nos candidatos petistas.

Para mitigar as suspeitas de falácia ecológica, utilizo microdados para estimar o efeito da filiação religiosa sobre o comportamento eleitoral dos indivíduos. Os resultados confirmam as evidências agregadas por município e mostram que, mantidos outros fatores constantes, os indivíduos de filiação evangélica pentecostal votam sistematicamente contra o PT nas eleições presidenciais brasileiras. Também no capítulo 2, estimo os efeitos da transição religiosa sobre o desempenho eleitoral do PT. Os resultados indicam que, nas eleições presidenciais entre 2010 e 2018, o PT aumentou seu suporte eleitoral apenas nos municípios onde houve crescimento católico entre 2000 e 2010. Por fim, comparando os municípios que completaram a transição religiosa (i.e. municípios que passaram a ter maioria evangélica em 2010) com municípios iguais em suas características, mas que não experimentaram o mesmo fenômeno, mostro que o PT obteve menor suporte eleitoral no grupo de municípios com maioria evangélica em todas as eleições presidenciais entre 2010 e 2018.

No capítulo 3, exploro os efeitos de vizinhança da variável religião (spillovers effects) com modelos de autocorrelação espacial. Os resultados confirmam os efeitos diretos (intramunicípio) discutidos no capítulo 2, mas também mostram importantes 
efeitos de vizinhança (entre municípios) da variável religião. O PT não apenas é menos votado nos municípios onde há maior presença pentecostal, existem também efeitos de vizinhança que redundam em forte rejeição ao partido nos clusteres pentecostais que se formam no território brasileiro. Fenômeno inverso é observado nos clusteres católicos e evangélicos tradicionais. Nestes locais, a votação do PT tende a ser maior em decorrência dos efeitos de vizinhança.

No capítulo 4, proponho um mecanismo explicativo para os resultados eleitorais apresentados nos capítulos 2 e 3. Argumento que os pastores e líderes pentecostais atuam como cabos eleitores (brokers) e desempenham um importante papel de mobilização dos eleitores de baixa renda que frequentam suas igrejas. Para tanto, combino informações inéditas da distribuição territorial de igrejas pentecostais com dados eleitorais georeferenciados, desagregados no nível distrito-bairro, para mostrar a influência dos pastores sobre o comportamento eleitoral de seus fiéis. Mantendo outros fatores constantes, a votação dos partidos de esquerda nas eleições presidenciais tende a ser menor nos locais de votação próximos (1-5 km) das igrejas pentecostais. Ademais, utilizo dados em painel, com informações sobre o mesmo indivíduo em sucessivos pontos no tempo, para mostrar que os resultados de nível agregado não são explicados pelo fato de os indivíduos mais conservadores serem mais propensos a aderir ao pentecostalismo. Os resultados indicam que os indivíduos mudam sua percepção moral após a conversão ao pentecostalismo (e não o contrário), passando a valorizar mais a honestidade em detrimento da competência dos candidatos e enxergando mais desonestidade nos candidatos à esquerda do espectro ideológico.

No capítulo 5, investigo como a filiação religiosa afeta a resposta do eleitorado a políticas redistributivas. Explorando dados de implementação do Programa Bolsa 
Família (PBF) no nível municipal, mostro que apenas o grupo dos beneficiários católicos recompensa o PT nas urnas pelo aumento do bem-estar produzido pelo programa de transferência de renda. Este resultado se mantém mesmo quando desconsiderados os municípios da região Nordeste (sugerindo que os resultados não são dirigidos pela maioria católica desta região) ou fazendo uso de dados de nível individual que reduzem as suspeitas de falácia ecológica.

Ainda no capítulo 5, comparo o Brasil com o caso chileno, contexto em que a transição religiosa também vem ocorrendo alavancada pelo crescimento pentecostal. Os resultados indicam efeitos eleitorais heterogêneos do Chile Solidario (CS), política de transferência condicional de renda implementada pelo Partido Socialista (PS) no Chile. Os eleitores evangélicos pentecostais são menos propensos a votar no partido que implementou essa política de transfência de renda, enquanto evangélicos tradicionais e católicos tendem a recompensar em maior proporção o PS pelo aumento do bem-estar produzido pelo programa. Concluo a análise sobre o caso chileno mostrando evidências adicionais de que o comportamento eleitoral dos pentecostais neste país também parece ser explicado pelo conservadorismo moral mais forte nesse grupo.

Na conclusão, apresento uma síntese dos resultados e discuto possíveis implicações para a redistribuição de renda, accountability e estratégias eleitorais dos partidos no Brasil. Encerro a tese argumentando que a transição religiosa não é um fenômeno meramente demográfico. O modo como os indivíduos votam e respondem às políticas redistributivas parece ser influenciado pela religião, motivo suficiente para que cientistas políticos e sociais incluam essa variável em seus modelos explicativos. 


\section{O Movimento Pentecostal no Brasil}

\subsection{Um fenômeno chamado pentecostalismo}

Nas últimas duas décadas, poucas mudanças foram mais marcantes na sociedade brasileira do que o crescimento da parcela da população que se declara evangélica (PIERUCCI, 2004; JACOB; HEES; WANIEZ, 2013; COUTINHO; GOLGHER, 2014). Entre 2000 e 2010, o número de cristãos evangélicos no país cresceu 61\%, alcançando 22,2\% (42.310.000) da população. Do total de evangélicos no Brasil, 57\% (24 milhões) se declaravam pentecostais em 2010. E dois a cada três novos convertidos às igrejas evangélicas pentecostais são provenientes do catolicismo, religião que perde $1 \%$ da população a cada ano (FRESTON, 2010). Mantidas as taxas de crescimento atual, a transição religiosa estará completa antes de 2030, o que elevará os evangélicos à condição de grupo religioso majoritário no Brasil (ALVES et al., 2017).

Enquanto as igrejas evangélicas tradicionais (e.g. Metodista, Presbiteriana, Batista e Episcopal), introduzidas pelo protestantismo missionário do século XIX, foram beneficiadas pelas diversas ondas de migração europeia para o Brasil (MATOS, 2011), o pentecostalismo logrou crescimento ao concentrar seus esforços de evangelização nas grandes cidades brasileiras (ALMEIDA; MONTEIRO, 2001; FAJARDO, 2011). Por isso, diferentemente das experiências observadas em outros países da América Latina, o pentecostalismo brasileiro é desproporcionialmente urbano (FRESTON, 2008).

Embora a origem do pentecostalismo se confunda com os escritos do pastor e teólogo John Wesley (1703-1791), o movimento ganhou contornos mais claros nas mãos 
de alguns de seus seguidores, como Charles Finney (1792-1875) e Charles Fox Parham (1873-1929). Finney, professor de teologia no Oberlin College, Ohio (EUA), foi o principal expoente do "Perfeccionismo de Oberlin", um movimento evangelista baseado na ideia de que a santidade deve ser encarada como um pressuposto e não como um alvo da vida cristã. Nesta corrente de pensamento, a vida cristã é enquadrada numa perspectiva evolutiva na qual o fiel passa por estágios de desenvolvimento espiritual. Assim, o processo de conversão individual deve ser precedido pelo batismo com o Espírito Santo ${ }^{1}$, uma espécie de "segunda benção" reservada apenas aos santos (CAMPOS, 2005).

As primeiras missões pentecostais em solo brasileiro remontam ao começo do século XX, quando dois missionários inspirados pelo pentecostalismo norte-americano iniciaram trabalhos de evangelização no Brasil. O primeiro deles, Luigi Francescon, um italiano radicado nos Estados Unidos da América (EUA), foi o responsável por fundar, em 1910, a Congregação Cristã no Brasil na cidade de São Paulo. Concomitatemente, Daniel Berg, um missionário de origem sueca, mas que recebeu treinamento nos EUA, iniciou os trabalhos da Assembleia de Deus em Belém do Pará.

Do momento de sua implantação até os dias de hoje, o pentecostalismo brasileiro passou por diversas metamorfoses (MARIANO, 2008), desde o processo de fragmentação das igrejas originárias em novas denominações idealizadas por lideranças locais, passando pela incorporação de elementos da cultura afro-brasileira em seus cultos (BIRMAN, 1996), até a decisão de integrar ativamente a esfera pública (MACHADO, 2006).

Como resultado do esforço de adaptação do pentecostalismo importado dos EUA

1 Termo utilizado para se referir ao processo pelo qual os fiés recebem dons divinos via contato com o Espírito Santo. Durante este processo de imersão no mundo espiritual, os fiés podem ser curados de doenças, experimentar visões, ouvir profecias ou falar línguas deconhecidas ou estrangeiras. 
Tabela 1 - Origem das cinco maiores denominações evangélicas pentecostais no Brasil

\begin{tabular}{lllll}
\hline \hline & & & Origem \\
\cline { 3 - 4 } Fundador & Igreja & País origem & Local no Brasil & Ano \\
\hline Luigi Francescon & Congregação Cristã no Brasil & Estados Unidos & São Paulo (SP) & 1910 \\
Daniel Berg & Assembleia de Deus & Estados Unidos & Belém (PA) & 1910 \\
Harold Williams & Igreja do Evangelho Quadrangular & Estados Unidos & S.J da Boa Vista (RJ) & 1951 \\
David Miranda & Igreja Deus é Amor & Brasil & São Paulo (SP) & 1962 \\
Manoel de Mello & Igreja Pentecostal O Brasil para Cristo & Brasil & São Paulo (SP) & 1979 \\
\hline \hline
\end{tabular}

Fonte: Elaborado pelo autor a partir de Matos (2011).

a alguns traços típicos da cultura brasileira, outras denominações evangélicas foram criadas por missionários brasileiros com o passar dos anos (MATOS, 2006). A tabela 1 apresenta informações de origem e fundação das cinco maiores igrejas pentecostais brasileiras. Destaque para a Igreja Deus é Amor, fundada por David Miranda, filho de agricultores paranaenses, que se converteu ao pentecostalismo e fundou sua própria igreja anos depois em São Paulo; e para a Igreja Pentecostal O Brasil para Cristo, fundada por Manoel de Melo em 1979, também na cidade de São Paulo.

A primeira geração (1910-1950) de igrejas e lideranças concentrou seus esforços na tarefa de expandir a influência do movimento pentecostal no Brasil, embora sem muito êxito (MACHADO, 2006). Neste período, as igrejas pentecostais se mantiveram distantes da política partidária brasileira como parte da estratégia de manutenção da separação entre a esfera do sagrado e do profano (FRESTON, 1994). A segunda geração do pentecostalismo brasileiro, capitaneada por lideranças locais em ascensão, como David Miranda (Igreja Deus é Amor) e Manoel de Mello (Igreja Pentecostal O Brasil para Cristo), lançou as bases para um rápido processo de expansão do pentecostalismo em antigos redutos católicos, especialmente nas áreas pobres urbanas. Por exemplo, em 1979, a Igreja Deus é Amor inagurou em São Paulo um templo para dez mil pessoas, naquela época, o maior templo evangélico no Brasil. 
Em 1980, apenas 3,9 milhões de brasileiros se declaravam evangélicos pentecostais. Em 2010, três décadas depois, esse número mais do que sextuplicou (24 milhões), um crescimento vertiginoso e acima da média da América Latina (FRESTON, 2010). Dentre outros fatores, este fenômeno pode ser explicado pelo: 1. limitado trabalho das igrejas evangélicas tradicionais para expandir sua presença no território brasileiro (FRESTON, 1994); 2. aumento da pobreza nas grandes cidades motivado pela migração das áreas rurais para os centros urbanos (CAMARGO; SOUZA, 1973; ALMEIDA; MONTEIRO, 2001); 3. existência de redes de apoio internas adaptadas às demandas da população mais vulnerável (LAVALLE; CASTELLO, 2004; MARQUES, 2010); 4. utilização de uma linguagem mais acessível que permitiu difundir regras e preceitos religiosos para as camadas menos escolarizadas da população (ALMEIDA, 2011); 5. maior capacidade de atração do público jovem em virtude de um culto menos litúrgico e aberto às demandas culturais locais (RIVERA, 2005; CUNHA, 2018).

Concomitantemente ao aumento do número de igrejas e membros, emergiu um novo entendimento sobre o papel que os evangélicos pentecostais deveriam exercer na esfera pública (FRESTON, 2006). Em 1986, após acordo entre lideranças e a definição de candidaturas próprias, o movimento pentecostal elegeu 33 parlamentares para a Assembleia Nacional Constituinte, a maior parte oriunda da Igreja Assembleia de Deus². Esse evento é considerado um marco da participação dos evangélicos pentecostais na política brasileira ao romper com uma longa tradição de apatia política e subserviência desse grupo (MACHADO, 2006).

2 Maior denominação evangélica no Brasil até os dias de hoje. De acordo com os dados da pesquisa realizada pelo instituto Datafolha, 34\% dos evangélicos brasileiros pertencem à Assembleia de Deus em 2016, seguidos pelas denominações Batista (11\%), Universal do Reino de Deus (8\%), Congregação Cristã no Brasil (6\%), Quadrangular (5\%), Deus é Amor (3\%), Adventista (3\%), Presbiteriana (2\%), Internacional da Graça de Deus (2\%), Mundial do Poder de Deus (2\%), dentre outras menos citadas. Instituto Datafolha. Perfil dos Evangélicos no Brasil. Disponível em: http:/ / media.folha.uol.com.br/datafolha/2016/12/28/da39a3ee5e6b4b0d3255bfef95601890afd80709.pdf. Acesso em: 28 Agosto 2019. 
Figura 3 - Peso do eleitorado evangélico pentecostal nas eleições presidenciais brasileiras (1940-2010)

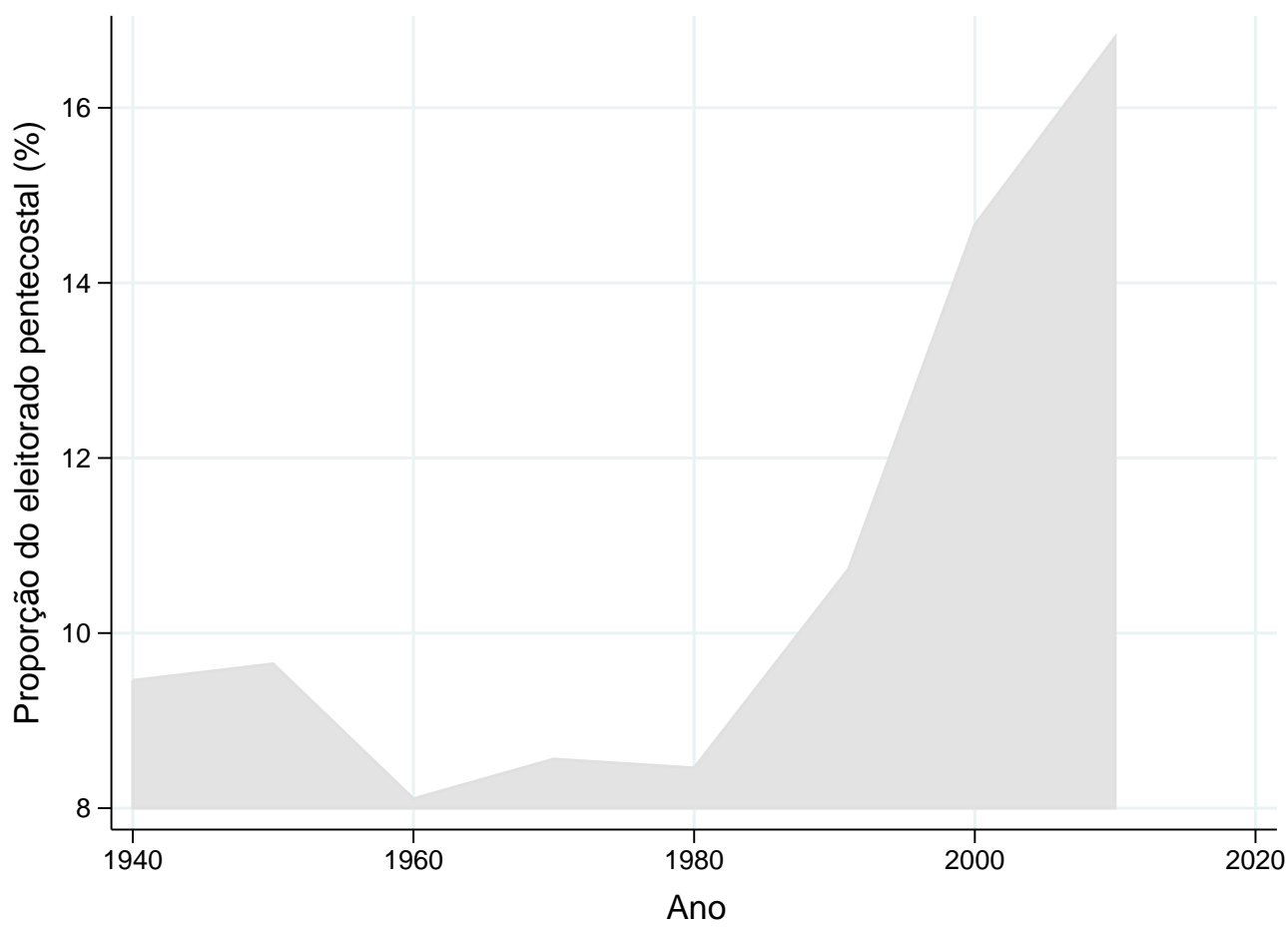

Nota: elaborado pelo autor a partir das estatísticas do século XX do Instituto Brasileiro de Geografia e Estatística (IBGE) e do Tribunal Superior Eleitoral (TSE). O eixo Y representa o número de eleitores pentecostais sobre o número total de eleitores brasileiros em cada ano da série.

O crescimento da representação dos evangélicos nas arenas formais de decisão é uma consequência do aumento do peso dos pentecostais no eleitorado brasileiro. Em 1940, os evangélicos pentecostais representavam cerca de 9\% do eleitorado brasileiro número que se manteve estável até os anos 1980, quando se observa um crescimento linear desse grupo. Como mostra a figura 3, os evangélicos pentecostais representavam mais de $16 \%$ do eleitorado brasileiro em 2010. Tendo em vista o crescimento registrado entre 2000 e 2010, é provável que mais de 20\% dos eleitores que votaram nas eleições de 2018 eram evangélicos pentecostais ${ }^{3}$.

3 Essa expectativa só poderá ser confirmada quando os dados do censo 2020 forem divulgados. De acordo com os dados da pesquisa Perfil dos Evangélicos no Brasil, realizada pelo instituto Datafolha em 2016, cerca de $29 \%$ da população brasileira eram evangélicos, sendo 22\% pentecostais e 7\% evangélicos tradicionais. Outros 50\% eram católicos seguidos pelo grupo sem religião (14\%), Espíritas, Kardecistas e espiritualistas (2\%), Umbandistas (1\%), Candomblecistas (1\%), Ateus (1\%) e outras religiões (2\%). Nesse levantamento realizado do dia 07 ao dia 08 de dezembro de 2016, foram conduzidas 2.828 entrevistas em 174 municípios, com margem de erro máxima 2 pontos percentuais para mais ou para 


\subsection{Quem são os evangélicos pentecostais brasileiros?}

Como argumentam ALMEIDA e BARBOSA (2015), o grupo dos evangélicos pentecostais é composto por indivíduos de baixa renda residentes em áreas periféricas dos grandes centros urbanos. De fato, as estimativas reportadas no Apêndice A informam que a proporção de evangélicos pentecostais é maior em locais com níveis mais elevados de urbanização, mesmo quando controladas por diversas outras variáveis de nível municipal disponíveis no censo do IBGE (2000 e 2010). Os dados de nível municipal também indicam que, mantidos outros fatores constantes, o pentecostalismo tende a ser predominante nas áreas com maior desigualdade de renda, diferentemente das religiões evangélica tradicional e católica (ver Apêndice A).

Dados de nível individual permitem traçar um quadro mais detalhado das características dos integrantes desse grupo. Neste caso, utilizo os dados do Estudo Eleitoral Brasileiro (ESEB, 2010) que foram coletados no mesmo ano do último censo demográfico realizado pelo IBGE. A amostra do ESEB é representativa para todo o território nacional e reúne cerca de 2 mil entrevistados. Uma primeira informação relevante é que os indivíduos pentecostais tendem a ser pobres. Como informa a tabela 2, 65\% dos indivíduos pentecostais amostrados em 2010 tinham uma renda familiar de até dois salários mínimos.

Na comparação com outros grupos religiosos, os pentecostais se diferenciam em outras dimensões importantes. Por exemplo, as mulheres são o grupo majoritário nesse segmento religioso (57\%), uma consequência, de acordo com Matos (2006), da maior abertura para o envolvimento das mulheres nas atividades eclesiásticas das

menos, considerando um nível de confiança de $95 \%$. Vale ressaltar que os dados dessa pesquisa não são comparáveis com as informações do Censo, uma vez que os critérios de amostragem utilizados pelas duas pesquisas não são os mesmos. 
igrejas pentecostais ${ }^{4}$. As outras religiões possuem um contigente médio de $50 \%$ de mulheres. A comparação entre as duas categorias indica uma diferença estatisticamente significante (IC de 95\%). Além disso, os dados sugerem um menor nível de escolaridade entre os pentecostais. Apenas $10 \%$ da amostra de evangélicos pentecostais tinham ensino superior completo em 2010, um proporção 3\% menor àquela observada entre os indivíduos de outras religiões (IC de 90\%).

Tabela 2 - Características sociodemográficas dos indivíduos pentecostais (2010)

\begin{tabular}{lccccc}
\hline \hline & Obs & Média (Pentecostais) & Média (Outros) & T & p-valor \\
\hline Pobre $(<2 \mathrm{SM})$ & 1,968 & .65084 & .6425 & 0.2740 & 0.7841 \\
& & $(.0278)$ & $(.0117)$ & & \\
Não branco & 1,990 & .5824 & .5670 & 0.4958 & 0.6201 \\
& & $(.0286)$ & $(.0120)$ & & \\
Mulher & 1,997 & .5719 & .5076 & 2.0513 & 0.0404 \\
& & $(.0286)$ & $(.0121)$ & & \\
Ensino superior & 1,997 & .1003 & .1319 & 1.8116 & 0.0654 \\
& & $(.0174)$ & $(.0082)$ & & \\
Nordestino & 1,997 & .1806 & .2850 & 3.7649 & 0.0002 \\
& & $(.0222)$ & $(.0109)$ & & \\
Direita (ideologia) & 1,104 & 7.267 & 6.215 & 3.7339 & 0.0002 \\
& & $(.2310)$ & $(.1041)$ & & \\
\hline \hline
\end{tabular}

Nota: compilado pelo autor a partir dos dados do ESEB (2010). A unidade de análise é o indivíduo. São considerados pobres os indivíduos com renda familiar mensal até dois salários mínimos.

Os dados apresentados na tabela 2 também revelam uma tendência dos indivíduos com filiação evangélica pentecostal se posicionarem mais à direita no espectro ideológico ${ }^{5}$. O valor médio de autoposicionamento dos evangélicos pentecostais é 7.26 contra 6.21 dos indivíduos de outros grupos religiosos (IC de 99\%). Vale destacar, ainda, a menor concentração de evangélicos pentecostais na região Nordeste. Em 2010, 18\% dos pentecostais residiam nessa região, um número inferior aos $28 \%$ de pentecostais

4 Um exemplo marcante da maior abertura do movimento pentecostal à participação feminina é a Igreja do Evangelho Quadrangular, fundada em 1927 nos EUA pela pregadora norte-americana Aimee Semple McPherson. As igrejas dessa denominação, implantadas no Brasil a partir de 1951, destacam-se pela maior abertura das atividades eclesiais para as mulheres.

5 O posicionamento ideológico dos indivíduos foi medido a partir da seguinte pergunta: "Pensando em direita e esquerda na política, como o(a) Sr (a) se considera? Zero significa que o(a) Sr (a) é de esquerda e 10 que o (a) é de direita". 
amostrados nas outras regiões do Brasil (IC de 99\%).

Figura 4 - Consumo de informação (mídias tradicionais) por filiação religiosa (2014)
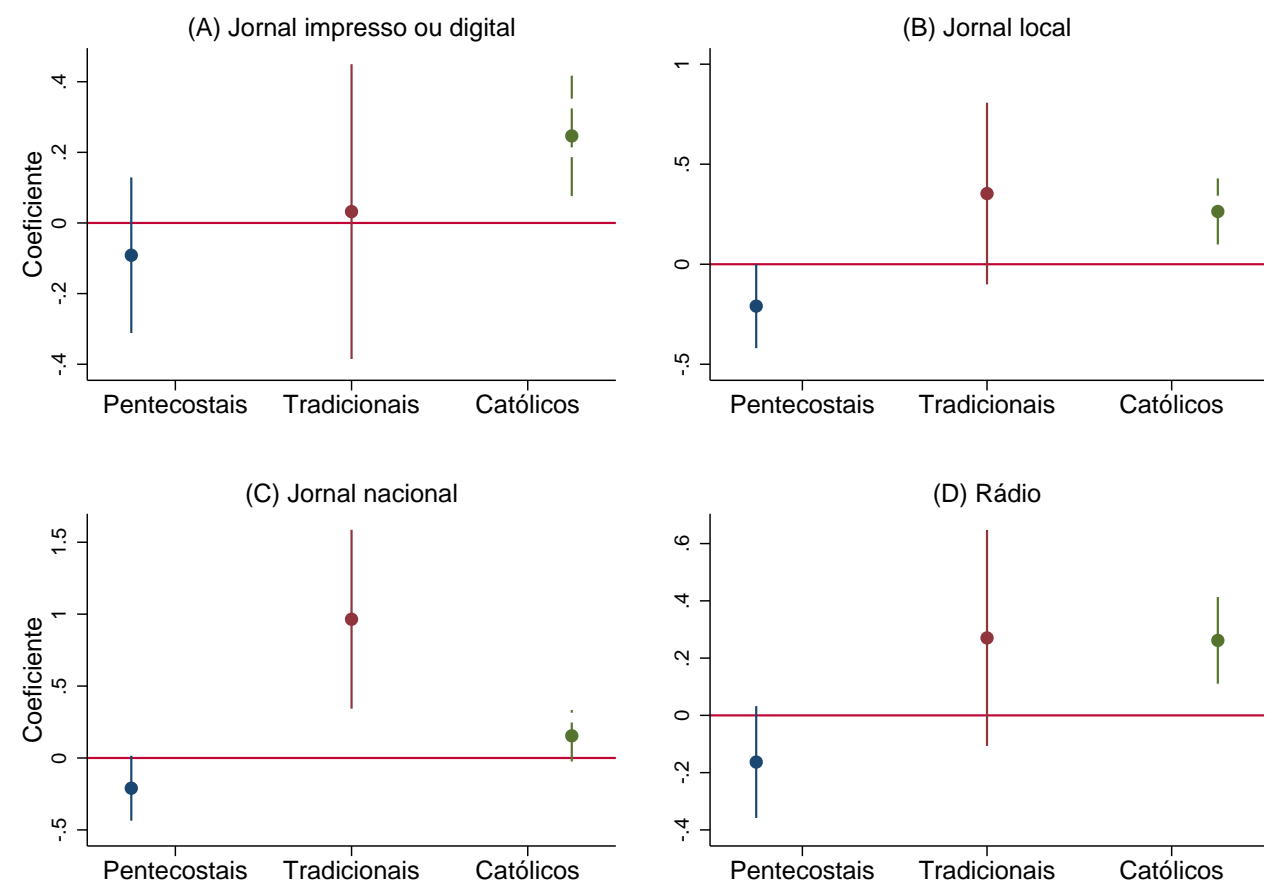

Nota: elaborado pelo autor a partir dos dados do Estudo Eleitoral Brasileiro (ESEB, 2014). A unidade de análise é o indivíduo $(\mathrm{N}=3,049)$. As seguintes perguntas foram utilizadas para mensurar o consumo de informação dos indivíduos: $\mathrm{O}(\mathrm{a}) \mathrm{sr}(\mathrm{a})$ tem costume de ler jornal na versão impressa, na versão digital pela internet ou ambas (painel A)? Essa semana o(a) sr(a) assistiu a algum telejornal de transmissão nacional, ou seja que passa em todo Brasil (painel B)? E essa semana o(a) sr(a) assistiu a algum telejornal regional, ou seja que passa notícias de sua cidade ou região (painel $\mathrm{C}$ )? $\mathrm{O}(\mathrm{a}) \operatorname{sr}(\mathrm{a})$ ouviu notícias no rádio esta semana (painel D)? Os modelos de regressão logística apresentados no painel A,B,C e D foram ajustados com erros padrões robustos utilizando os seguintes controles: idade, sexo, cor, renda, escolaridade, região, status ocupacional e nível de religiosidade dos indivíduos.

Outra característica relevante desse grupo é o baixo consumo de informação de seus integrantes, o que os torna potencialmente dependentes de suas lideranças religiosas para se informar durante o processo eleitoral. Como evidencia a figura 4, os indivíduos de filiação evangélica pentecostal tendem a consumir menos informação em jornais impressos ou digitais (A), assistir menos ao noticiário local (B) ou nacional (C), bem como possuem menor predisposição para ouvir o noticiário via rádio (D) ${ }^{6}$. Os fiéis dos outros dois grupos tendem a consumir mais informação dessas diversas fontes,

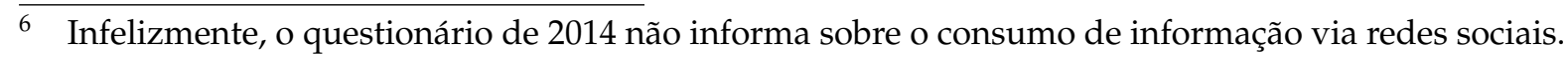


sobretudo aqueles de filiação católica, na média, mais escolarizados e com maior renda ${ }^{7}$.

Figura 5 - Frequência à igreja e confiança nas lideranças da igreja por filiação religiosa (2014)
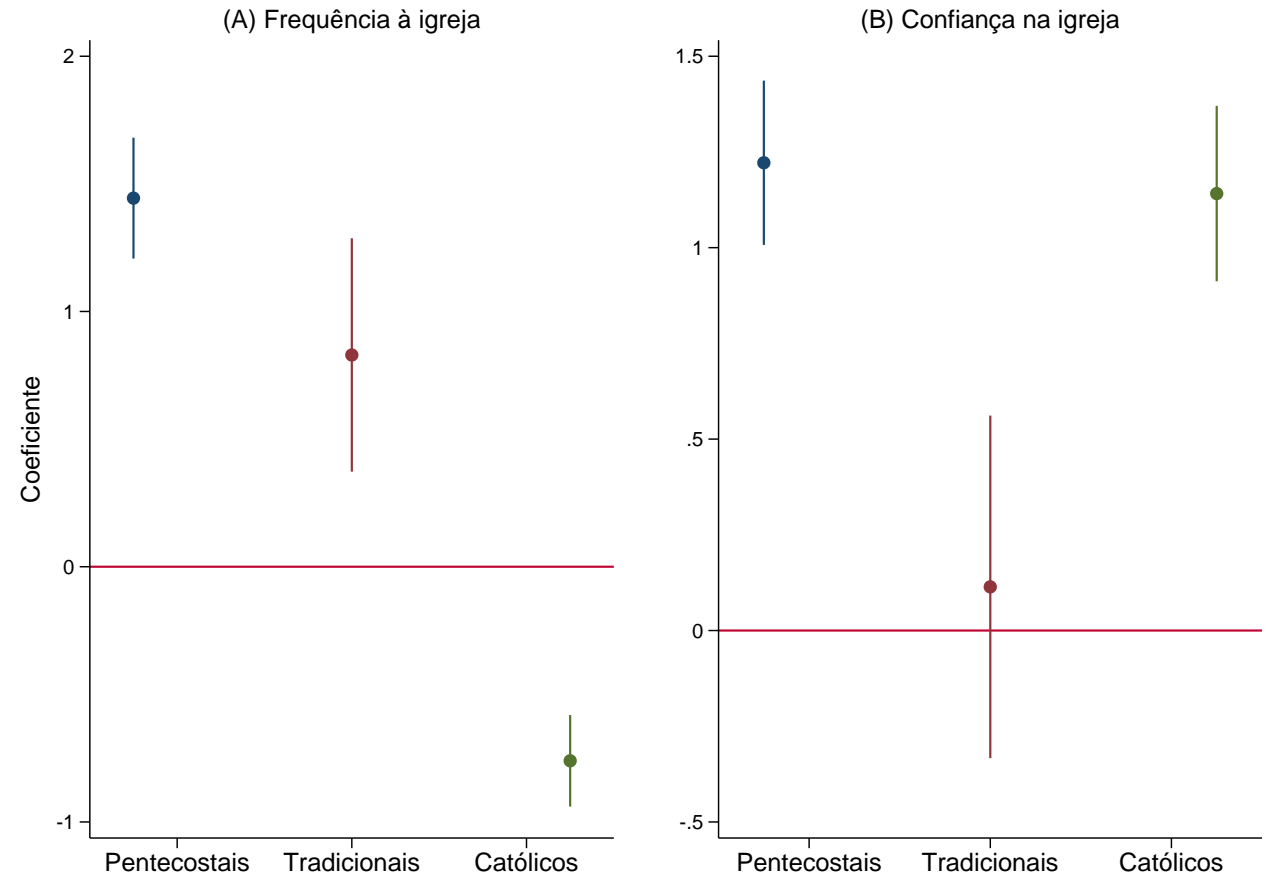

Nota: elaborado pelo autor a partir dos dados do Estudo Eleitoral Brasileiro (ESEB, 2014). A unidade de análise é o indivíduo $(\mathrm{N}=3,049)$. A seguinte pergunta foi utilizada para mensurar a frequência com que os indivíduos vão à igreja (painel A): "Sem considerar batizados e casamentos, com que frequência o(a) sr(a) vai à Missa ou culto religioso?". A figura 5 utiliza "mais de um vez por semana" e "uma vez por semana" como categorias de referência. A seguinte pergunta foi utilizada para mensurar o nível de confiança dos indivíduos na igreja (painel B): De maneira geral, como o(a) $\operatorname{sr}(a)$ avalia a atuação da igreja evangélica/católica. A figura 5 utiliza "ótima" e "boa" como categorias de referência. Os modelos de regressão logística apresentados na figura 5 foram ajustados com erros padrões robustos, utilizando os seguintes controles: idade, sexo, cor, renda, escolaridade, região, status ocupacional e nível de religiosidade dos indivíduos.

Além disso, os cristãos pentecostais passam mais tempo nos cultos sob influência de suas lideranças. A figura 5 informa a probabilidade de um indivíduo frequentar a igreja pelo menos uma vez ou mais de uma vez na semana, de acordo com sua filiação religiosa (A). Mantidos outros fatores constantes, um indivíduo com filiação evangélica pentecostal tem uma chance ${ }^{8}$ mais de 5 vezes maior de frequentar a igreja

7 Para uma discussão sobre o perfil e hábitos dos diferentes grupos religiosos no Brasil, ver Rosas e Muniz (2014).

8 Neste trabalho, quando faço uso do termo "chance", me refiro à razão de chance dos coeficientes estimados por meio dos modelos logísticos. Para tanto, implemento a fórmula sugerida por Pampel (2000) para transformar os coeficientes das regressões logísticas em razão de chance ou probabilidades. 
uma vez por semana ou mais (IC de 95\%). Vale ressaltar também que, na comparação com evangélicos tradicionais e católicos, os pentecostais são aqueles que mais confiam em suas lideranças religiosas (B). A chance de um evangélico pentecostal avaliar bem a liderança de sua igreja é cerca de 4 vezes maior na comparação com outras religiões (IC de 95\%). Os católicos também avaliam bem suas lideranças enquanto os evangélicos tradicionais demonstram maior nível de desconfiança.

Figura 6 - Nível de simpatia pelo petismo por filiação religiosa (2017)



Nota: elaborado pelo autor a partir dos dados do Latino Barômetro (LAPOP, 2017). A unidade de análise é o indivíduo $(\mathrm{N}=1,532)$. A seguinte pergunta foi utilizada para mensurar a simpatia ao petismo. Falando de alguns grupos de pessoas, poderia informar o quanto gosta ou desgosta de Petistas e Simpatizantes do PT? Agora usamos uma escala de 1 a 10, na qual 1 significa "desgosto muito" e 10 significa "gosto muito". Na figura 6, as categorias de referência são 9 e 10. O modelo de regressão logística apresentado na figura 6 foi ajustado com erros padrões robustos, utilizando os seguintes controles: idade, sexo, cor, renda, escolaridade, região e nível de religiosidade dos indivíduos.

Por serem mais permeáveis às posições políticas e ao direcionamento ideológico de suas lideranças religiosas, os evangélicos pentecostais tendem a ser menos heterogênos em suas preferências eleitorais. Como salienta Rosas (2015), os cultos pentecostais são frequentemente um espaço de mobilização política onde uma identidade eleitoral é construída. Neste contexto, cabe ao pastor a tarefa de criar um inimigo eleitoral comum 
que, como discuto em detalhes no capítulo 4, tende a ser um partido ou candidato de esquerda.

Por exemplo, a figura 6 mostra a probabilidade de um indivíduo ser simpatizante do petismo de acordo com a sua filiação religiosa. Na comparação com outras religiões, os evangélicos pentecostais são aqueles com menor simpatia ao petismo. Na média, a probabilidade de um indivíduo com essa filiação religiosa gostar de petistas e simpatizantes do PT é 21\% menor (IC de 95\%). As estimativas para os grupos evangélicos tradicionais e católicos não são significantes, o que sugere menor resistência ao PT entre os indivíduos dos dois grupos.

\subsection{O conservadorismo moral pentecostal}

A presunção de que as religiões cristãs tornam os indivíduos mais conservadores tende a naturalizar o juízo impreciso de que os diferentes grupos religiosos são igualmente conservadores. Na prática, existem importantes diferenças no posicionamento desses grupos.

Entre os católicos brasileiros, por exemplo, expressões de forte conservadorismo moral se confundem com apoio público a agendas sociais mais progressistas (DELGADO; PASSOS, 2007). Por exemplo, entre 1965 e 1985, anos de censura e limitada liberdade de expressão no Brasil, movimentos surgidos no interior do catolicismo foram de suma importância no processo de redemocratização. Enquanto a Teologia da Libertação forneceu os elementos doutrinários que serviram para justificar a contestação pública de algumas das medidas implementadas pelos governos militares, as comunidades eclesiais de base cumpriram um importante papel de politização das 
camadas mais populares (BARBOSA, 2010). Já no período democrático, as lideranças católicas, sobretudo aquelas ligadas ao movimento da renovação carismática ${ }^{9}$, têm se movimentado no sentido da preservação do status quo e defesa dos valores da família (ALMEIDA, 2017).

Os evangélicos pentecostais ganharam destaque na sociedade brasileira por adotarem uma postura em defesa dos valores da "família cristã". A este respeito, Bohn (2004) pontua que o peso do grupo pentecostal ajuda a explicar a grande resistência à descriminalização do aborto entre os brasileiros de baixa renda. Da mesma forma, a oposição ao casamento homoafetivo ou a resistência à discussão da educação sexual nas escolas se revelam de forma mais contundente entre os evangélicos pentecostais (MACHADO, 2018).

A figura 7 mostra o apoio a duas importantes pautas morais, legalização da maconha e união entre pessoas do mesmo sexo, de acordo com a filiação religiosa dos indivíduos. Mantidos outros fatores, como sexo, idade, raça e escolaridade constantes, os indivíduos que se declaram evangélicos pentecostais são menos tolerantes à proposta de legalização da maconha (A). Os dados também revelam resultados estatisticamente não significantes para o grupo dos evangélicos tradicionais e dos católicos, o que sugere que os indivíduos que integram esses dois grupos são menos resistentes a possíveis mudanças na legislação dessa matéria.

A figura 7 também informa o nível de tolerância dos diferentes grupos religiosos em relação à união entre pessoas do mesmo sexo (B). Embora, na média, os evangélicos

9 Este segmento da Igreja Católica brasileira sofre forte influência das igrejas evangélicas pentecostais, inclusive reproduzindo algumas das práticas eclesiásticas e religiosas nas Missas. Alguns trabalhos sugerem que a criação da renovação carismática foi uma estratégia deliberada das lideranças católicas no Brasil para conter o avanço do pentecostalismo entre as camadas mais pobres da população (MARIZ, 2003; VALLE, 2004). 
Figura 7 - Apoio a pautas morais no Brasil por filiação religiosa (2015)
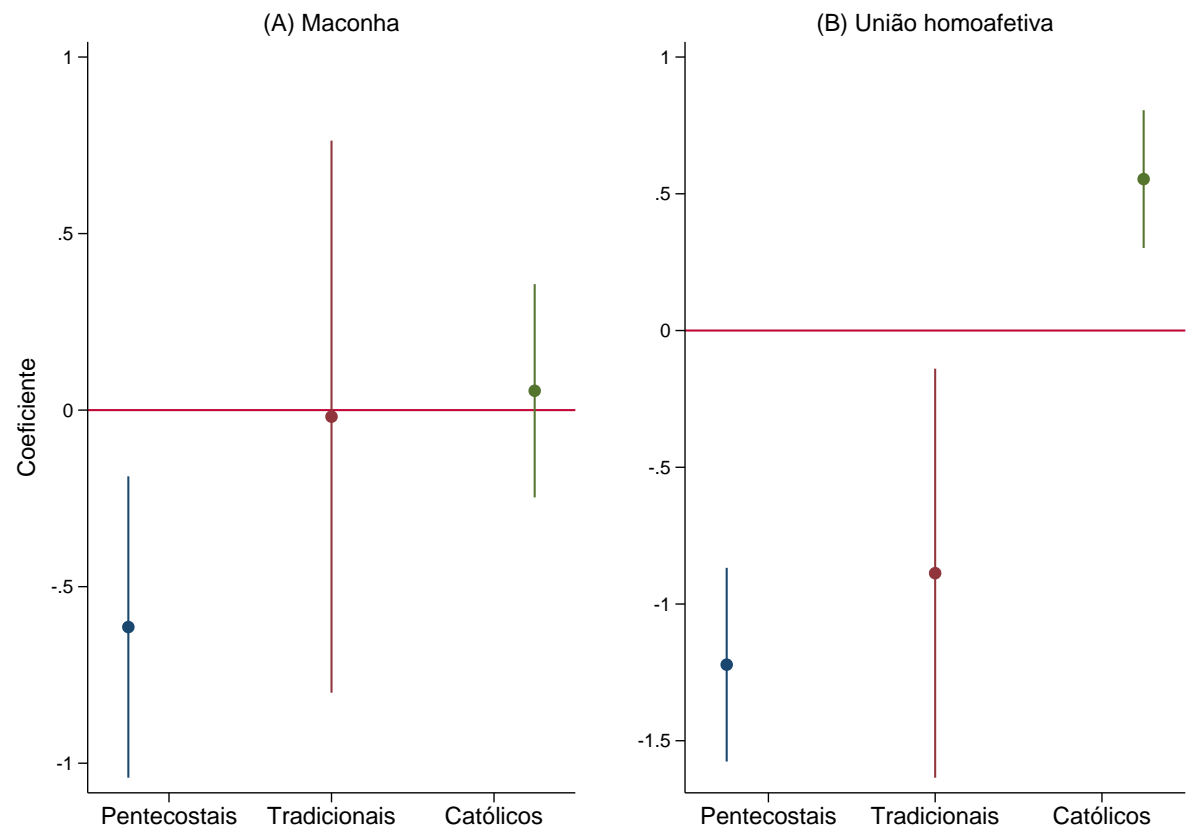

Nota: elaborado pelo autor a partir dos dados do Latinobarómetro database (2015). A unidade de análise é o indivíduo $(\mathrm{N}=1,250)$. O painel A (Maconha) representa a relação entre a filiação religiosa do indivíduo e o seu apoio à legalização da maconha. Neste caso, "concorda muito"ou "concorda"são as categorias de referência. O painel B (União homoafetiva) representa a relação entre a filiação religiosa do indivíduo e o seu apoio à união de casais homoafetivos. Também neste caso, "concorda muito"ou "concorda"são as categorias de referência. Os modelos de regressão logística apresentados na figura 7 foram ajustados com erros padrões robustos, utilizando os seguintes controles: idade, sexo, cor, escolaridade e nível de religiosidade dos indivíduos.

tradicionais também sejam contrários à união homoafetiva, os resultados revelam um maior nível de intolerância entre os evangélicos pentecostais. Na comparação com outras religiões, a probabilidade de apoio à união homoafetiva é 57\% menor para um evangélico tradicional e 71\% menor para um evangélico pentecostal. Por fim, a figura 7 mostra que, mantidos outros fatores constantes, indivíduos com filiação católica tendem a se colocar a favor da união homoafetiva (IC de 95\%).

Em suma, o forte conservadorismo moral dos evangélicos pentecostais contrasta com níveis menos elevados de conservadorismo entre os indivíduos filiados a outras religiões cristãs, sobretudo no caso dos católicos, que se destacam por seu maior pro- 
gressismo nas questões morais ${ }^{10}$. No próximo capítulo, investigo se a variação das características e preferências dos indivíduos que integram esses grupos religiosos se traduz em diferentes estratégias de voto nas disputas presidenciais.

10 Os resultados reportados neste capítulo vão ao encontro das análises descritivas divulgadas pela pesquisa Perfil dos Evangélicos no Brasil (Datafolha), citada anteriormente neste capítulo. Por exemplo, quando perguntados se um casal gay poderia adotar uma criança, $64 \%$ dos evangélicos se dizem contrários. Proporção significativamente menor é observada entre católicos (33\%) e na população brasileira em geral (40\%). 


\section{Religião e voto no Brasil}

\subsection{A religião como um preditor do voto}

Parte da sociedade brasileira assistiu atônita ao crescimento de Jair Bolsonaro (PSL) durantes as eleições presidenciais de 2018. Considerado outsider antes das eleições e tido por muitos como opção inviável devido às suas posições políticas extremas, o candidato conseguiu canalizar para sua candidatura o apoio de parte substantiva da oposição ao PT, rompendo com a polarização PT versus PSDB marcante nas disputas presidenciais pelo menos desde as eleições de $1994^{1}$. A figura 8 mostra a correlação entre a votação de Jair Bolsonaro nas eleições de 2018 e a votação dos candidatos do PSDB nas eleições presidenciais entre 2002 e 2014.

A votação do PSDB entre 2006 e 2014 parece explicar parte importante da votação do PSL em 2018. Em geral, os municípios onde o PSDB foi bem votado em 2006, 2010 e 2014 foram também aqueles onde o candidato do PSL recebeu uma votação expressiva nas eleições de 2018. Os mapas apresentados no apêndice B reforçam essa interpretação ao mostrar a distribuição geográfica da votação do PSDB e do PSL entre 2006 e 2018. As bases territoriais eleitorais do PSL em 2018 tendem a se confundir com as bases territoriais eleitorais do PSDB entre 2006 e $2014^{2}$.

1 Para uma análise detalhada do comportamento dos eleitores brasileiros nas eleições presidenciais, ver Samuels e Zucco (2018).

2 Esses dados parecem apontar na mesma direção que as evidências qualitativas apresentadas por Kalil (2018). A pesquisa etnográfica realizada pela autora sugere 16 diferentes perfis de eleitores do candidato Jair Bolsonaro. As mais de 1000 entrevistas realizadas durante protestos entre 2013 e 2018 sugerem que o candidato de direita foi capaz de capturar o apoio da porção anti-petista do eleitorado que havia votado em candidatos do PSDB em eleições anteriores. Portanto, "a questão mais importante a respeito da tipificação dos eleitores é a de que não existe o "eleitorado de Bolsonaro" como a caracterização de um grupo social específico"(p.8). 
Figura 8 - Correlação entre a votação do PSDB (2002-2014) e do PSL (2018) nas eleições presidenciais
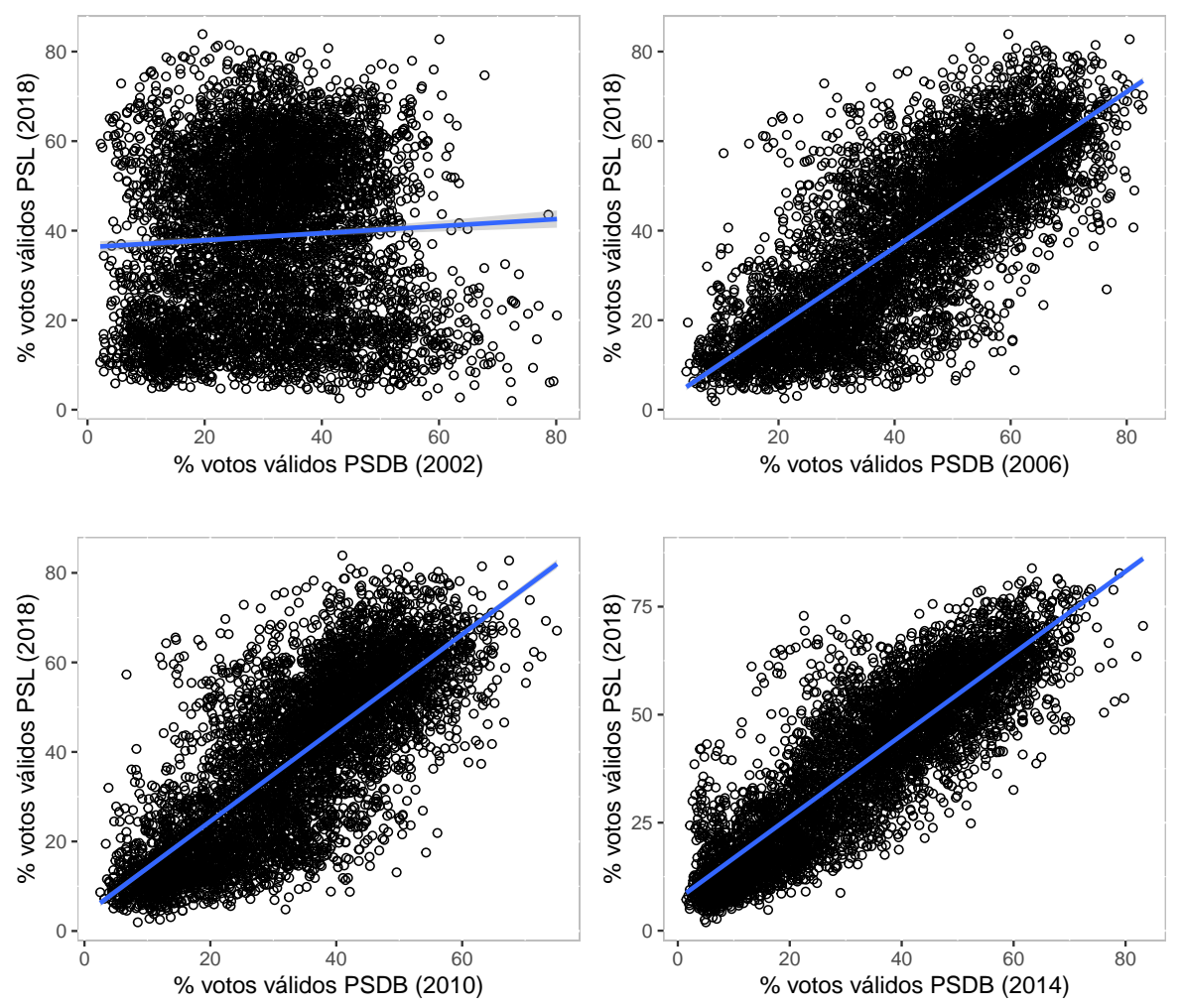

Nota: elaborado pelo autor a partir dos dados do Tribunal Superior Eleitoral (TSE). A unidade de análise é o município $(\mathrm{N}=5,565)$ e a proporção de votos válidos de cada partido (PSDB e PSL) é calculada com base nos dados do segundo turno de cada eleição presidencial.

Neste capítulo, mostro que os evangélicos pentecostais são parte importante dessa porção do eleitorado que tende a não votar no PT nas eleições presidenciais, a mesma que ajudou a eleger o candidato do PSL em 2018. A figura 9 mostra a relação entre filiação religiosa e suporte eleitoral ao PT nas eleições presidenciais entre 2006 e 2018. Maior concentração de católicos nos municípios brasileiros significou mais votos para o PT em todas as eleições neste período. Em contraste, quanto maior a proporção de evangélicos pentecostais, menor o suporte eleitoral aos candidatos do PT. Esta correlação negativa, também observada nas evidências de nível individual (como detalho nas seções seguintes), ajuda a explicar porque eleitores de baixa renda tendem a não votar em candidatos de esquerda nas eleições presidenciais brasileiras. 
Figura 9 - Correlação entre religião e voto no PT nas eleições presidenciais (2006-2018)
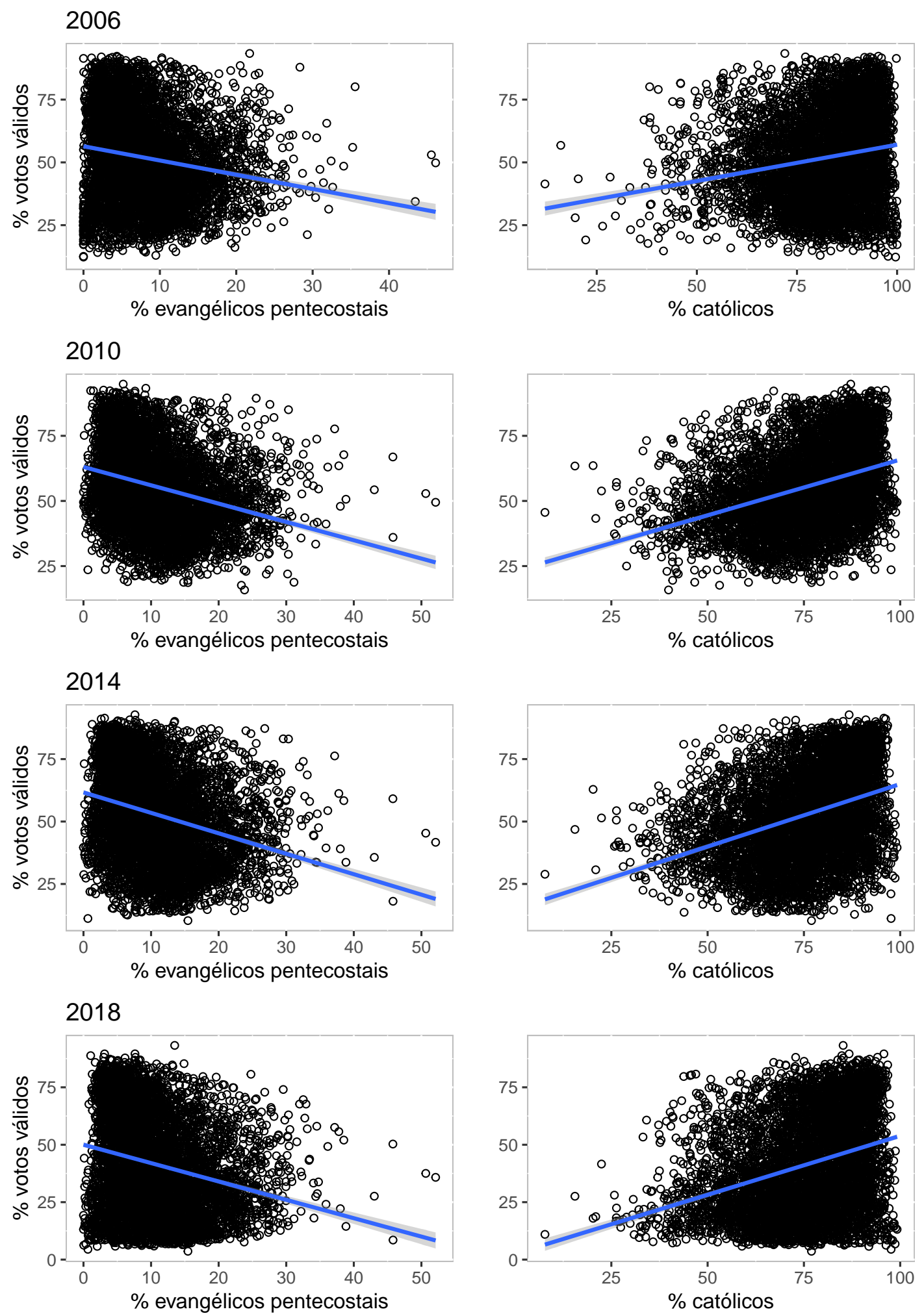

Nota: elaborado pelo autor a partir dos dados do Tribunal Superior Eleitoral (TSE) e do Instituto Brasileiro de Geografia e Estatística (IBGE). A unidade de análise é o município $(\mathrm{N}=5,565)$ e a proporção de votos válidos é calculada com base nos dados do segundo turno de cada eleição presidencial. O eixo y representa a proporção de votos válidos do Partido dos Trabalhadores (PT) nas eleições presidenciais. O eixo $x$ representa a proporção de indivíduos, em cada município brasileiro, que se declaravam evangélicos pentecostais e católicos, respectivamente, no censo realizado pelo IBGE em 2010. Os dados do segundo turno nas eleições presidencias são tomados como referência. 


\subsection{Religião e voto: evidência de nível municipal}

Uma característica fundamental da variável religião é a sua distribuição não uniforme. As populações de estados e municípios brasileiros variam substantivamente no que se refere à composição dos grupos religiosos. Como descrito nos mapas do apêndice $C$, existe maior concentração de evangélicos pentecostais nos estados do Rio de Janeiro e São Paulo, bem como nas regiões Norte e Centro-Oeste. As igrejas evangélicas tradicionais se concentram nos estados da região Sul, mas também contam com "ilhas"de seguidores espalhadas pelo território brasileiro. Espírito Santo, Roraima e o Distrito Federal são alguns exemplos. O Nordeste, por sua vez, é um reduto católico. No capítulo 3, investigo esses efeitos de vizinhança da variável "religião".

Nesta seção, exploro os efeitos da heterogeneidade religiosa no território brasileiro sobre a votação do PT, único partido de esquerda que esteve no segundo turno das eleições presidenciais brasileiras realizadas entre 1989 (as primeiras diretas promovidas após a ditadura) e 2018. Se, como argumento neste trabalho, o pentecostalismo mobiliza os eleitores de baixa renda contra os partidos de esquerda, deveríamos observar menos votos por redistribuição à medida que cresce o número de pentecostais no nível municipal.

Para testar essa hipótese, utilizo os dados de filiação religiosa do IBGE desagregados por município. As informações do censo de 2000 e 2010 permitem, não apenas saber a proporção de indivíduos filiados aos macrogrupos religiosos (e.g. católicos e evangélicos), mas também estimar a proporção de indivíduos que integram diferentes categorias dentro desses grupos. Para os fins deste trabalho, desagrego a variável religião disponibilizada pelo IBGE em três categorias: católicos, evangélicos pentecostais e 
evangélicos tradicionais ${ }^{3}$.

Utilizo um modelo de mínimos quadrados ordinários para estimar a relação entre a concentração de indivíduos de um dado grupo religioso e o suporte eleitoral ao PT no nível municipal. Formalmente, estimo a seguinte equação:

$$
Y_{i j}=X_{i j} \beta+w_{i j}+u_{i j}+e_{i j}
$$

Onde $\boldsymbol{Y}_{i j}$ é uma variável contínua que mensura a proporção de votos válidos do PT no município $i$ na eleição $\boldsymbol{j}, \boldsymbol{X}_{\boldsymbol{i}} \boldsymbol{\beta}$ é a variável de interesse e representa a proporção de eleitores de um dado grupo religioso ${ }^{4}$ no município $i$ na eleição $\boldsymbol{j}, \boldsymbol{w}_{\boldsymbol{i}}$ é um vetor de covariáveis relacionadas às características do município, enquanto $e_{i j}$ denota o uso de erros clusterizados no nível do município. Dado que $\boldsymbol{Y}_{i j}$ também se correlaciona com outras características de nível municipal, utilizo os seguintes controles para estimar a equação 2.1: taxa de analfabetismo, taxa de pobreza, renda per capita, índice de desigualdade medido pelo coeficiente de Gini, índice de desenvolvimento humano $(\mathrm{IDH})^{5}$, número de beneficiários do Bolsa Família ${ }^{6}$ e uma variável que indica a região de cada município $\boldsymbol{i}$.

A figura 10 apresenta as estimativas desagregadas por filiação religiosa. Os resultados informam que o crescimento do grupo dos indivíduos que se declaram

3 Os dados do censo do IBGE permitem outras desagregações, como "Espíritas", "Umbandistas e candomblecistas" e "Sem religião". Neste trabalho, concentro-me nas três maiores categorias de religiões cristãs no Brasil.

4 Neste trabalho, quando emprego dados agregados por município, utilizo os dados sobre filiação do censo de 2000 para estimar os resultados para 2006 e os dados do censo de 2010 para as estimativas de 2010, 2014 e 2018. Portanto, é provável que a proporção de evangélicos seja subestimada nos anos mais distantes da realização do censo, ao mesmo tempo que é razoável supor uma superestimação da proporção dos católicos. Isso porque os evangélicos vêm experimentando uma tendência de aumento, enquanto a proporção de católicos diminui desde o censo de 2000.

5 Utilizo dados do censo de 2010 para calcular esses indicadores para todos os município brasileiros existentes no ano da realização da pesquisa.

6 Utilizo dados do Ministério do Desenvolvimento Social (MDS) referentes a cada ano eleitoral. 
Figura 10 - Voto no PT nas eleições presidenciais por filiação religiosa - nível municipal (2006-2018)
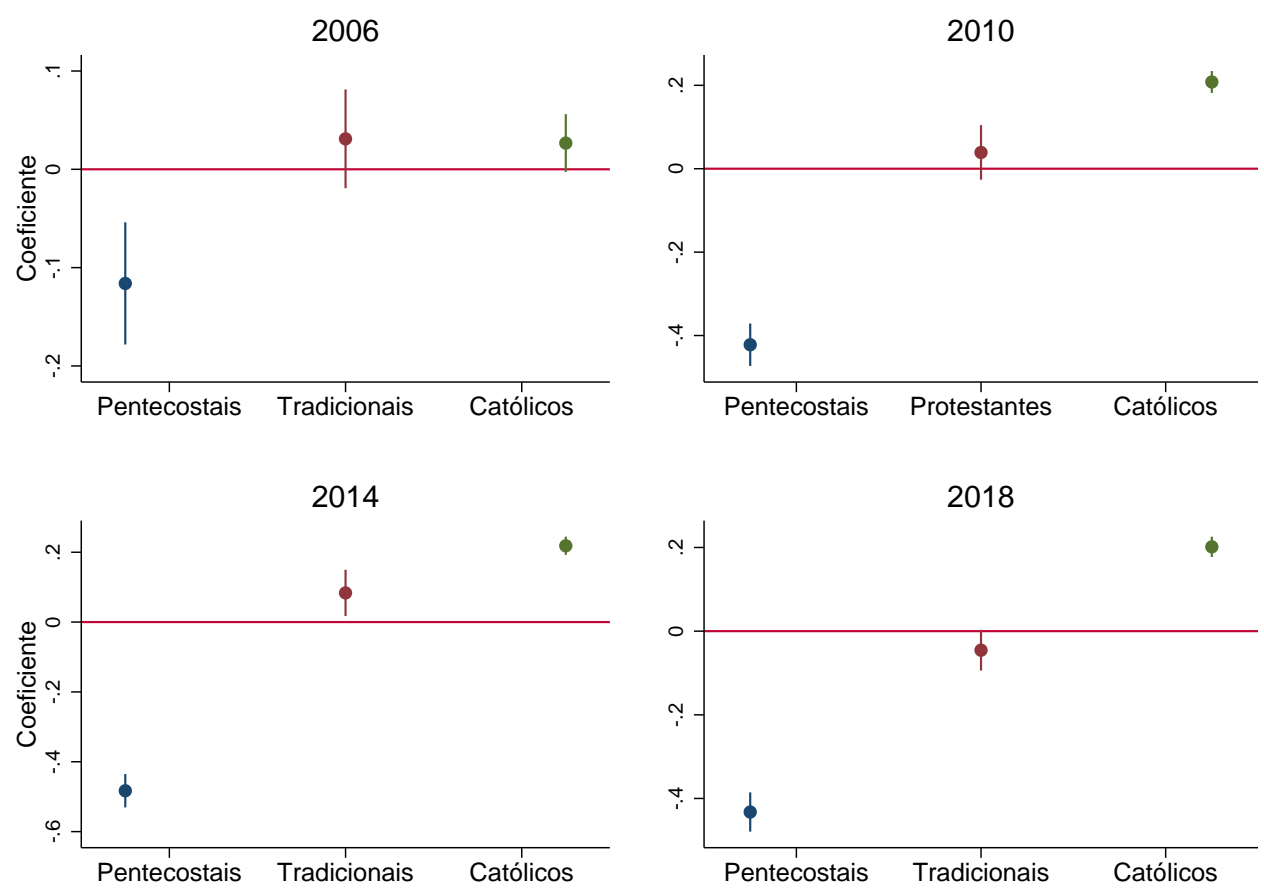

Nota: elaborado pelo autor a partir dos dados do Estudo do Instituto Brasileiro de Geografia e Estatística (IBGE) e do Tribunal Superior Eleitoral (TSE). A unidade de análise é o município $(\mathrm{N}=5,565)$. Os modelos de mínimos quadrados ordinários apresentados na figura 10 foram ajustados com erros clusterizados no nível do município. As seguintes covariáveis foram utilizadas: taxa de analfabetismo, taxa de pobreza, renda per capita, índice de desigualdade medido pelo coeficiente de Gini, índice de desenvolvimento humano (IDH), proporção de beneficiários do Bolsa Família e uma variável que informa a região de cada município.

pentecostais está associado à diminuição dos votos válidos para o PT nas eleições presidenciais. Em 2014, por exemplo, o incremento de um ponto percentual dos evangélicos pentecostais significou um diminuição média de -.4830 ponto percentual (pp) nos votos do PT em cada município. A figura 10 mostra resultados similares nas eleições de 2006 (-.1160 pp), 2010 (-.4220 pp) e 2018 (-.4323 pp), o que sugere um padrão consistente do eleitorado pentecostal no sentido de votar contra os candidatos do PT.

Na outra direção, o crescimento do eleitorado católico é positivamente associado com a proporção de votos válidos do PT. À medida que cresce o contingente de católicos em um dado município, cresce também o suporte eleitoral ao PT. Esse padrão é consis- 
tente e estatisticamente significante em todas as eleições presidenciais entre 2006 e 2018. Em 2018, por exemplo, para cada acréscimo de um ponto percentual no contigente de católicos, o PT obteve um incremento médio de .2015 pp (IC de 95\%) em sua proporção de votos válidos nas eleições presidenciais. Os resultados para a categoria evangélicos tradicionais são menos consistentes, embora apontem na direção esperada na maior parte dos casos. Nas eleições de 2006, 2010 e 2014, o crescimento desse grupo no nível municipal esteve associado ao aumento de votos para os candidatos do PT, mas o efeito é estatisticamente significante apenas nas eleições de 2014 (IC de 95\%). Em 2018, a estimativa sugere um efeito negativo, porém indistiguível de zero.

\subsection{Filiação religiosa e voto: evidência de nível individual}

Uma crítica possível aos resultados apresentados na figura 10 é que as estimativas podem ser afetadas por falácia ecológica ${ }^{7}$. Como os resultados são agregados por município, não é possível ter certeza se a rejeição eleitoral ao PT é de fato explicada pelo comportamento eleitoral dos evangélicos pentecostais, nem que o maior suporte eleitoral deste partido vem do eleitorado católico.

Para mitigar essa suspeita, investigo a relação entre filiação religiosa e preferência eleitoral utilizando dados do LAPOP (2006), ESEB (2010 e 2014) e Datafolha (2018) O questionário de 2006 do ESEB não informa se o entrevistado era beneficiário do Programa Bolsa Família, um importante preditor do voto no PT nas eleições de 2006 (HUNTER; POWER, 2007; SOARES; TERRON, 2008). Por isso, faço uso da pesquisa

7 A falácia ecológica consiste em pensar que um relacionamento observado para grupos (dados de nível agregado) necessariamente se reflete no comportamento dos indivíduos (KING; FOX, 1999).

8 Até o fechamento deste trabalho, as pesquisas do LAPOP e do ESEB referentes às eleições de 2018 não haviam sido divulgadas para o público, por isso utilizo a pesquisa de intenções de voto do Datafolha realizada na véspera do segundo turno das eleições de 2018. Infelizmente, esta última não informa se o indivíduo era um beneficiário do Programa Bolsa Família na data de realização da entrevista. 
do LAPOP de 2008 que informa o voto dos indivíduos nas eleições presidenciais de

2006. Neste caso, o dado não permite desagregar o grupo evangélico entre pentecostais e tradicionais ${ }^{9}$, mas informa as características indivíduais necessárias para estimar a probabilidade de voto no PT. Utilizo um modelo de regressão logística para estimar a probabilidade de um indivíduo votar no PT dada a sua filiação religiosa, mantendo outros fatores constantes. Formalmente, estimo a seguinte equação:

$$
Y_{i j}=X_{i j} \beta+w_{i j}+u_{i j}
$$

Onde $\boldsymbol{Y}_{i j}$ é uma variável binária que indica se o indivíduo $i$ votou no PT em uma dada eleição ${ }^{10} \boldsymbol{j}, \boldsymbol{X}_{\boldsymbol{i}} \boldsymbol{\beta}$ é uma variável binária que indica se o indivíduo $\boldsymbol{i}$ pertence a uma dada categoria religiosa na eleição $\boldsymbol{j}, \boldsymbol{w}_{i j}$ é um vetor de covariáveis relacionadas às características dos indivíduos, enquanto $\boldsymbol{u}_{i j}$ denota o termo de erro. Dado que $\boldsymbol{Y}_{i j}$ também se correlaciona com outras características de nível individual, utilizo os seguintes controles para estimar a equação 2.2: idade, sexo, renda, escolaridade, raça, status ocupacional, percepção da economia ${ }^{11}$, preferência partidária, região, frequência à igreja e uma variável que indica se o indivíduo é um beneficiário do Programa Bolsa Família.

A figura 11 apresenta as estimativas desagregadas por filiação religiosa. Nas

9 Diferentemente do questionário do ESEB de 2014, por exemplo, que apresenta uma lista de denominações de orientação pentecostal e outra lista de denominações tradicionais para que o respondente aponte sua igreja, a pesquisa de 2008 do LAPOP apresenta aos indivíduos evangélicos duas escolhas possíveis: evangélicos pentecostais e evangélicos tradicionais. Esse tipo de categorização tende a inflar artificialmente a categoria outros, dado que os indivíduos tendem a se identificar mais com a denominação (i.e. Assembleia, Batista, Quadrangular, Presbiteriana) de suas igrejas do que com suas respectivas categorias de análise (i.e. Pentecostal ou Tradicional).

10 Diferentemente das pesquisas do LAPOP e do ESEB, o questionário do Datafolha captura a intenção de voto do indivíduo na véspera do segundo turno das eleições presidenciais de 2018.

11 A percepção dos indivíduos acerca da situação econômica do país é captada pela seguinte questão: "Na sua opinião, a atual situação econômica do Brasil está melhor, igual ou pior que há doze meses atrás?". 
Figura 11 - Voto no PT nas eleições presidenciais por filiação religiosa - nível individual (2006-2018)


Nota: elaborado pelo autor a partir dos dados do Latin American Public Opinion Project (LAPOP, 2008, $\mathrm{N}=1,497)$, Estudo Eleitoral Brasileiro (ESEB, 2014, $\mathrm{N}=3,049)$ e Datafolha $(2018, \mathrm{~N}=3,077)$. A unidade de análise é o indivíduo. Os modelos de regressão logística apresentados na figura 11 foram ajustados com erros padrões robustos, utilizando os seguintes controles: idade, sexo, renda, escolaridade, raça, status ocupacional, percepção da economia, preferência partidária, região, frequência à igreja (com a exceção do modelo para a eleição de 2018) e uma variável que indica se o indivíduo é um beneficiário do Programa Bolsa Família (com a exceção do modelo para a eleição de 2018).

eleições de 2006, a probabilidade de um indivíduo evangélico votar no PT foi 32\% menor na comparação com outros grupos religiosos (IC de 95\%). A estimativa referente aos católicos aponta na direção oposta. Mantidos outros fatores constantes, a probabilidade de um católico votar no PT foi 43\% maior (IC de 95\%). As estimativas para 2010 e 2014 informam um quadro mais detalhado e sugerem heterogeneidades na categoria "evangélico". Os resultados sugerem uma associação positiva entre ser evangélico tradicional e o voto no PT em 2010, enquanto a estimativa para 2014 é estatisticamente não significante nos níveis convencionais. Em contraposição, o evangélico pentecostal é o eleitor com a menor probabilidade de apoiar o PT nas urnas. Mantidos outros fatores 
constantes, a probabilidade de um indivíduo deste grupo votar no PT foi $16 \%$ menor em 2010 (IC de 90\%) e 33\% menor em 2014 (IC de 95\%). As eleições de 2018 seguem o padrão observado em 2014, embora o coeficiente para o grupo dos evangélicos tradicionais seja negativo e estatisticamente significante (IC de 99\%). Esse resultado pode ser tanto uma consequência da forma como este grupo é categorizado no questionário do Datafolha ${ }^{12}$, quanto um efeito do recente processo de "pentecostalização"do movimento protestante brasileiro $^{13}$.

Em geral, os resultados desta seção confirmam o padrão observado nos dados agregados por município. Os indivíduos que se declaram católicos têm maior propensão a votar no PT, enquanto os evangélicos tendem a se opor às candidaturas petistas, puxados pela forte rejeição ao PT entre os eleitores pentecostais.

\subsection{Transição religiosa e comportamento eleitoral}

Na maior parte dos municípios brasileiros, os católicos continuam sendo maioria. No entanto, impulsionado pelos pentecostais, o grupo dos indivíduos que se declaram evangélicos cresce de forma acelerada no Brasil. O Censo de 2010 mostrou, pela primeira vez na história do país, maioria evangélica em vários municípios. Nesta seção, exploro o efeito dinâmico dessa transição religiosa comparando o desempenho eleitoral do PT nos municípios que experimentaram crescimento evangélico com aqueles onde houve

12 Diferentemente do ESEB, o questionário do Datafolha agrupa as igrejas em algumas categorias de evangélicos. Na categoria "Evangélica", que seria a equivalente da categoria "Evangélica Tradicional neste trabalho, são agrupadas tanto as igrejas históricas (e.g. Luterana, Metodista e Presbiteriana) como igrejas do movimento protestante renovado, como a Batista Coluna de Fogo e a Batista Missão da Fé.

13 Como discute Rosas (2015), existe um movimento recente de "pentecostalização" do protestantismo histórico brasileiro que tem levado algumas lideranças desse segmento a replicar parte das práticas do pentecostalismo. Uma delas é a aceitação da Teologia da Dominação, doutrina segundo a qual os cristãos têm a missão de exercer liderança, dominar e ditar regras na sociedade de acordo com os valores do reino de Deus. 
crescimento do segmento católico.

Se as lideranças pentecostais são avessas às políticas progressistas e mobilizam seus fiés contra os partidos políticos que as defendem, deveríamos esperar um pior desempenho dos partidos de esquerda onde é possível observar aumento do grupo evangélico pentecostal. Por outro lado, o crescimento quantitativo dos evangélicos tradicionais e dos católicos deveria significar menor resistência aos partidos de esquerda. O uso combinado dos dados dos censos de 2000 e 2010 permite testar essas hipóteses ${ }^{14}$. Para tanto, utilizo um modelo de mínimos quadrados ordinários para estimar o efeito da transição religiosa nos municípios brasileiros sobre a proporção de votos válidos do PT. Formalmente, estimo a seguinte equação:

$$
Y_{i j}=X_{i j} \beta+w_{i j}+u_{i j}+e_{i j}
$$

Onde $\boldsymbol{Y}_{i j}$ é uma variável contínua que mensura a proporção de votos válidos do PT no município $\boldsymbol{i}$ na eleição $\boldsymbol{j}, \boldsymbol{X}_{\boldsymbol{i}} \boldsymbol{\beta}$ é a variável de interesse que mensura crescimento percentual de um dado grupo religioso entre 2000 e 2010 no município $i, \boldsymbol{w}_{i j}$ é um vetor de covariáveis relacionadas às características do município, enquanto $e_{i j}$ denota o uso de erros clusterizados no nível do município ${ }^{15}$. Também neste caso, utilizo uma série de controles para estimar $\boldsymbol{X}_{\boldsymbol{i}} \boldsymbol{\beta}$.

A figura 12 mostra que, nos municípios onde houve crescimento da parcela católica da população, o PT teve melhor desempenho eleitoral nas eleições de 2010, 2014 e 2018. Na média, para cada ponto percentual de crescimento da população católica, o

14 Os dados de 2000 e 2010 são utilizados para calcular o crescimento percentual, entre 2000 e 2010, dos diferentes grupos religiosos nos 5,565 municípios brasileiros existentes em 2010.

15 Seguindo a recomendação de Abadie et al. (2017), clusterizo os erros no nível onde ocorre o tratamento. Neste caso, o município. 
Figura 12 - Voto no PT nas eleições presidenciais de acordo com o crescimento dos grupos religiosos (2010-2018)
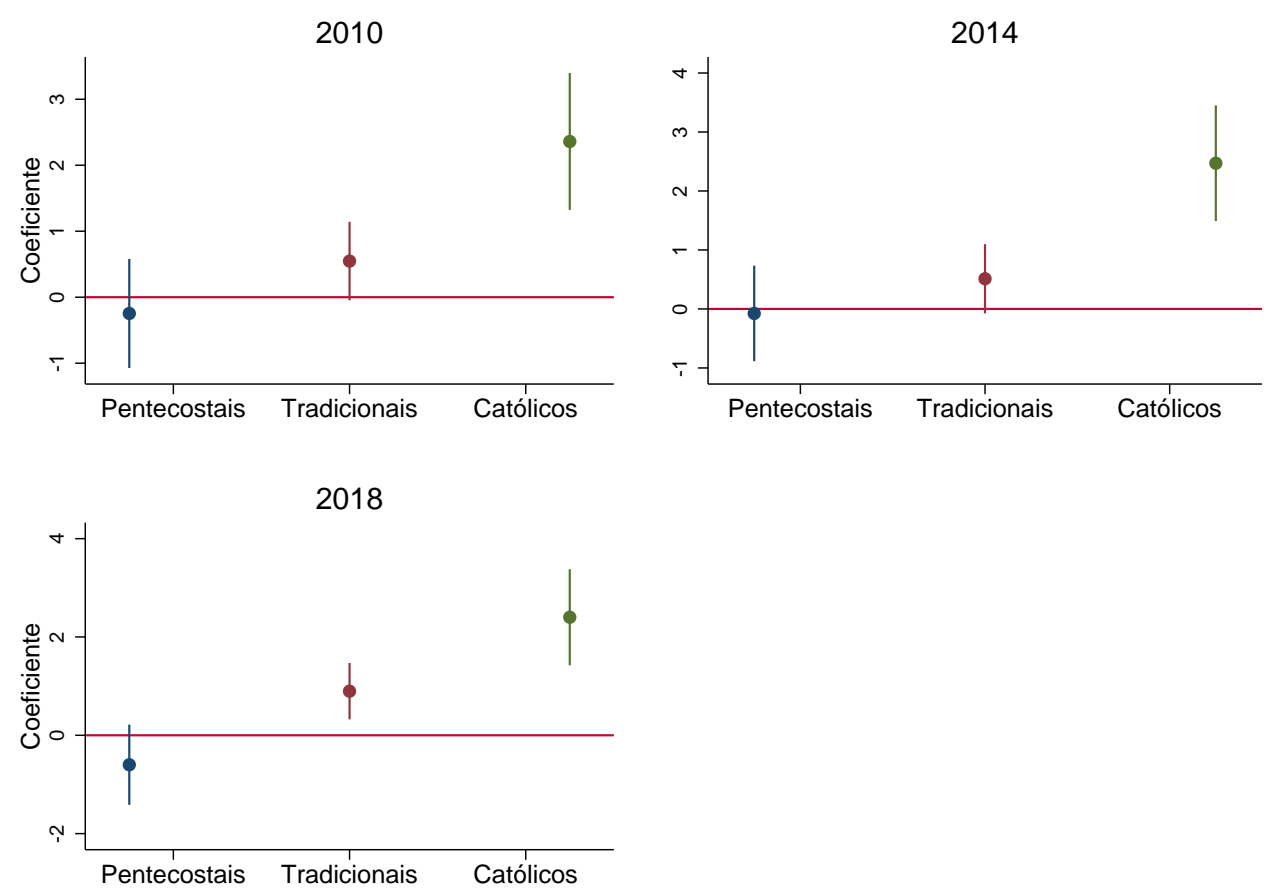

Nota: elaborado pelo autor a partir dos dados do Estudo do Instituto Brasileiro de Geografia e Estatística (IBGE) e do Tribunal Superior Eleitoral (TSE). A unidade de análise é o município $(\mathrm{N}=5,565)$. Os modelos de mínimos quadrados ordinários apresentados na figura 12 foram ajustados com erros clusterizados no nível do município. As seguintes covariáveis foram utilizadas: taxa de analfabetismo, taxa de pobreza, renda per capita, índice de desigualdade medido pelo coeficiente de Gini, índice de desenvolvimento humano (IDH), número de beneficiários do Bolsa Família e uma variável que informa a região de cada município.

PT obteve um aumento de cerca de 2.36 pp nas eleições de 2010. Padrão similar pode ser obervado nas eleições de 2014 (2.47 pp) e 2018 (2.40 pp) com magnitudes sensivelmente maiores. $\mathrm{O}$ mesmo pode ser dito sobre os municípios que experimentaram crescimento do grupo evangélico tradicional, embora, neste caso, o efeito da transição sobre a votação do PT tenha sido mais modesto. Para cada ponto percentual de crescimento dos evangélicos tradicionais entre 2000 e 2010, o PT obteve um aumento de 0.547 pp na votação de 2010 e 0.512 pp em 2014. Um efeito um pouco maior, próximo de 1 ponto percentual (.8974 pp), pode ser observado em 2018. Por fim, cabe registrar que as estimativas apontam efeitos negativos e não significantes da votação do PT nos locais 
onde houve aumento da parcela pentecostal da população. Em outros termos, os dados indicam um crescimento nulo do PT nas localidades que experimentaram crescimento pentecostal entre 2000 e 2010.

Uma forma mais conservadora de analisar o efeito da dinâmica religiosa sobre o comportamento eleitoral é analisando o desempenho eleitoral do PT nos municípios que completaram a transição religiosa ${ }^{16}$ em 2010. O apêndice F lista os municípios que tinham maioria evangélica em 2010. Do total de 49, 27 tinham maioria evangélica tradicional e 22 tinham maioria evangélica pentecostal. Enquanto a maioria evangélica do primeiro grupo pode ser explicada pelo trabalho missionário entre os imigrantes de origem europeia que se estabeleceram nos estados do Rio Grande do Sul e Santa Catarina, o segundo grupo é resultante da expansão evangélica nas áreas mais urbanizadas de São Paulo e Rio de Janeiro ${ }^{17}$.

Em virtude da heterogeneidade de preferências no grupo evangélico, divido os municípios em dois grupos de tratados. Aqueles que completaram a transição religiosa e tinham maioria evangélica tradicional em $2010(\mathrm{~N}=27)$ e aqueles que completaram a transição religiosa e tinham maioria evangélica pentecostal em $2010(\mathrm{~N}=22)$. Dado o maior conservadorismo moral e o maior nível de engajamento político das lideranças pentecostais, a desvantagem eleitoral do PT deveria ser maior nos municípios nos quais o eleitorado pentecostal é maioria. Seguindo a lógica do argumento proposto neste trabalho, a desvantagem eleitoral do PT nos municípios com maioria evangélica tradicional deveria ser menor, quando existente.

Utilizo uma série de características de nível municipal ${ }^{18}$ para encontrar muni-

\footnotetext{
16 Municípios onde os evangélicos passaram a ser maioria.

17 Por exemplo, apenas dois municípios da região Nordeste tinham maioria evangélica em 2010: São Pedro dos Crentes (MA) e Sirinhaém (PE).

18 Utilizo as seguintes características de pré-tratamento (dados do censo IBGE de 2000) para realizar
} 
cípios equivalentes àqueles que completaram a transição religiosa. Esse processo de pareamento torna os dois grupos de municípios iguais em todas as dimensões passíveis de observação, com exceção da variável religião. Para tanto, utilizo um modelo probit para estimar a probabilidade, $\boldsymbol{p}(\boldsymbol{x})$, de um município ter completado a transição religiosa em função de suas características, como representado na notação 2.4.

$$
p(x)=\operatorname{Pr}[D=1 \mid X=x]
$$

Figura 13 - Exemplo do efeito do pareamento sobre a balanceamento das variáveis de nível municipal

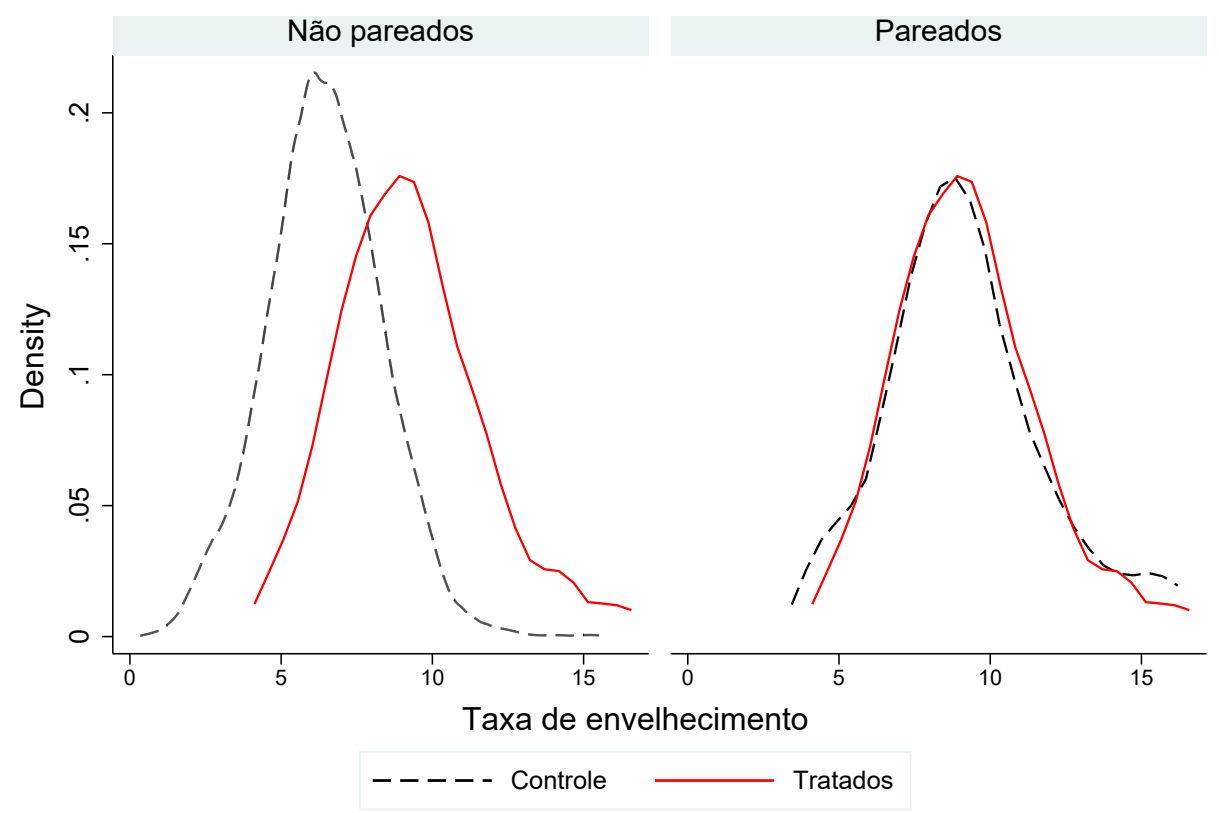

Nota: elaborado pelo autor a partir dos dados do Estudo do Instituto Brasileiro de Geografia e Estatística (IBGE) e do Tribunal Superior Eleitoral (TSE). A unidade de análise é o município ( $\mathrm{N}=5,565)$. Pareamento realizado a partir do algoritmo propensity score matching.

Embora não seja possível comparar um mesmo município com o seu contrafac-

o pareamento dos municípios: expectativa de vida, taxa de fertilidade, taxa de mortalidade, taxa de sobrevida aos 40 anos, taxa de sobrevida aos 60 anos, taxa de envelhecimento, expectativa de anos de estudo, desigualdade de renda medida pelo coeficiente de Gini, taxa de pobreza, taxa de vulnerabilidade, renda per capita dos mais pobres, população no mercado de trabalho formal, população economicamente ativa e tamanho da população. 
tual $^{19}$, o balanceamento produzido pelo pareamento das variáveis nos permite comparar a votação do PT nos municípios que completaram a transição religiosa, $\boldsymbol{Y}^{\mathbf{1}} \mid \boldsymbol{D}=1$, com aqueles que não completaram, $\boldsymbol{Y}^{0} \mid \boldsymbol{D}=\mathbf{0}$, mas que são iguais a $\boldsymbol{Y}^{\mathbf{1}} \mid \boldsymbol{D}=\mathbf{1} \mathrm{em}$ todas as dimensões que podemos observar. A figura 13 mostra o resultado do pareamento utilizando a variável taxa de envelhecimento como exemplo ${ }^{20}$. O painel à esquerda (não pareado) reporta a distribuição da variável nos municípios que tinham maioria evangélica em 2010 (tratamento) e nos municípios que não tinham maioria evangélica em 2010 (controle). Os dois grupos são claramente não balanceados. O painel à direita (pareado) mostra visualmente que o pareamento força o balanceamento do grupo, de modo que a diferença entre os dois grupos deixe de ser estatisticamente significante.

Formalmente, estimo o efeito do tratamento sobre o grupo tratado (Average Treatment Effect on treatement group, ATET ) como representado na notação 2.5.

$$
E\left[Y^{1} \mid D=1\right]-E\left[Y^{0} \mid D=0\right]
$$

A figura 14 reporta as estimativas de cada eleição entre 2010 e 2018 por grupo religioso. Nos municípios com maioria evangélica pentecostal, é possível observar uma substantiva desvantagem eleitoral dos candidatos do PT nas eleições presidenciais. Em 2010, na comparação com outros municípios com características similares, a votação do PT foi 7.20 pp menor (IC de 99\%) no grupo de municípios com maioria pentecostal. A estimativa correspondente às eleições de 2014 informa resultado parecido: na média, a votação do PT foi 7.49 pp menor (IC de 99\%) nas localidades com maioria pentecostal. A desvantagem do PT foi ainda maior em 2018, quando a votação do partido foi 14.57

${ }_{19}$ O mesmo município sem a ocorrência da transição religiosa.

20 O resultado do pareamento de todas as variáveis utilizadas para estimar os modelos apresentados na figura 14 são reportados no apêndice $\mathrm{E}$. 
pp menor (IC de 99\%) nos municípios que tinham maioria pentecostal em 2010.

Figura 14 - Transição religiosa e voto no PT nas eleições presidenciais (2010-2018)

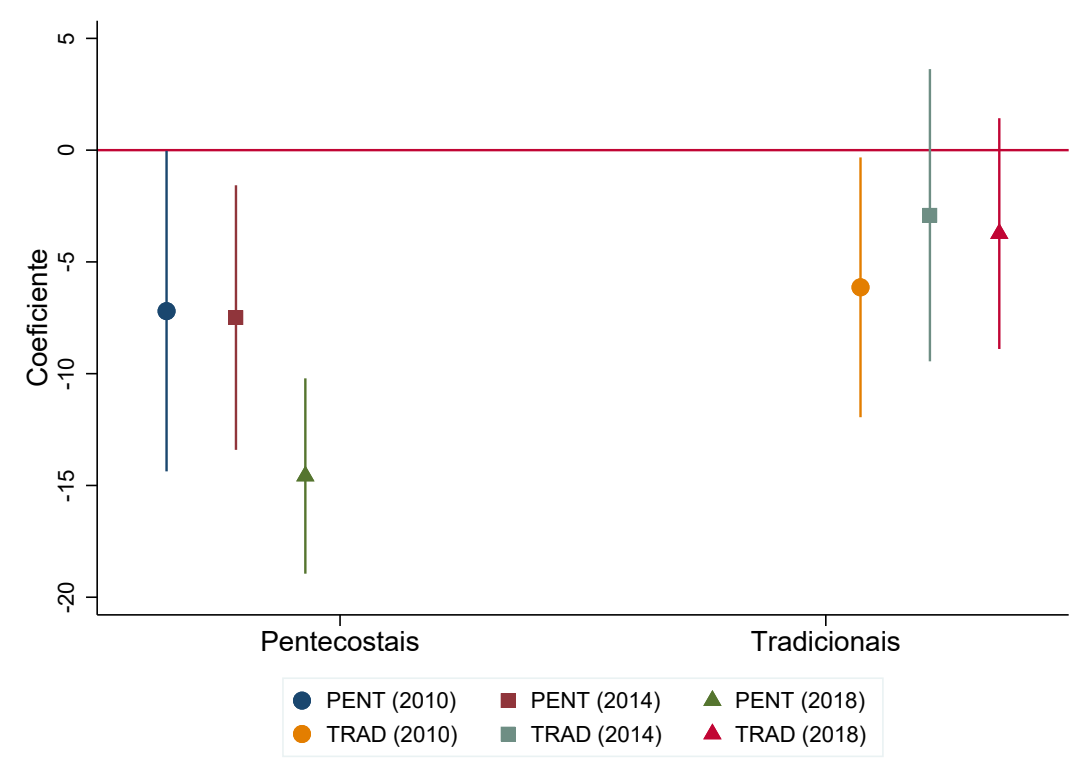

Nota: elaborado pelo autor a partir dos dados do Estudo do Instituto Brasileiro de Geografia e Estatística (IBGE) e do Tribunal Superior Eleitoral (TSE). A unidade de análise é o município (N = 98). PENT = Pentecostais. TRAD = Tradicionais. Os propensity matching scores foram calculados utilizando um modelo probit. O pareamento dos grupos foi realizado considerando as seguintes variáveis de nível municipal: expectativa de vida, taxa de fertilidade, taxa de mortalidade, taxa de sobrevida aos 40 anos, taxa de sobrevida aos 60 anos, taxa de envelhecimento, expectativa de anos de estudo, desigualdade de renda medida pelo coeficiente de Gini, taxa de pobreza, taxa de vulnerabilidade, renda per capita dos mais pobres, população no mercado de trabalho formal, população economicamente ativa e tamanho da população. Todas as variáveis são referentes ao censo de 2000 (pré-tratamento).

Nos municípios com maioria evangélica tradicional, as estimativas da figura 14 sugerem um comportamento menos estável dos eleitores desse grupo. Em 2010, na comparação com outros municípios com características similares, a votação do PT foi 6.13 pp menor (IC de 95\%). No entanto, as estimativas para as eleições de 2014 e 2018 são estatisticamente não significantes nos níveis convencionais, indicando menor rejeição ao PT nos municípios com maioria evangélica tradicional. O padrão consistente de desvantagem eleitoral do PT nos municípios com maioria pentecostal contrasta com a menor rejeição nos locais onde os evangélicos tradicionais eram maioria em 2010. 


\subsection{Mecanismos alternativos}

As evidências da seção anterior indicam que os evangélicos pentecostais tendem a rejeitar o PT nas urnas. Neste trabalho, interpreto esses resultados como um efeito do trabalho de mobilização das lideranças pentecostais que fazem uso de argumentos morais para minar a credibilidade dos partidos e candidatos de esquerda junto ao eleitorado de baixa renda.

Um possível mecanismo alternativo é que os esquemas de corrupção revelados nos governos petistas ajudaram a sedimentar um sentimento antipetista entre os eleitores desse grupo. A análise do comportamento eleitoral dos diferentes grupos religiosos antes da chegada do PT à presidência permite elucidar essa questão. Se a variável "corrupção" explica o voto dos pentecostais nas eleições presidenciais, deveríamos observar nenhuma ou menor rejeição ao PT em 2002, as eleições que antecederam a chegada do PT à Presidência da República.

A figura 15 reporta as estimativas de mínimos quadrados ordinários para as eleições presidenciais de 2002. À medida que cresce a população evangélica pentecostal no nível municipal, diminuem os votos válidos do PT nas eleições de 2002. No outro extremo, o crescimento da população católica significou maior suporte eleitoral ao PT. Os evangélicos tradicionais também tenderam a votar contra o PT, diferentemente do padrão observado a partir das eleições de 2006. De todo modo, os resultados das eleições de 2002 indicam que a rejeição do eleitorado pentecostal aos candidatos do PT antecedeu os escândalos de corrupção associados aos governos petistas entre 2003 e $2016^{21}$.

21 Luiz Inácio Lula da Silva ocupou a Presidência da República entre 2003 e 2010. Dilma Rousseff, sua sucessora, ocupou o cargo entre janeiro de 2011 e 31 de agosto de 2016, quando foi afastada por um processo de impeachment. 
Figura 15 - Voto no PT nas eleições presidenciais por filiação religiosa - eleição placebo (2002)

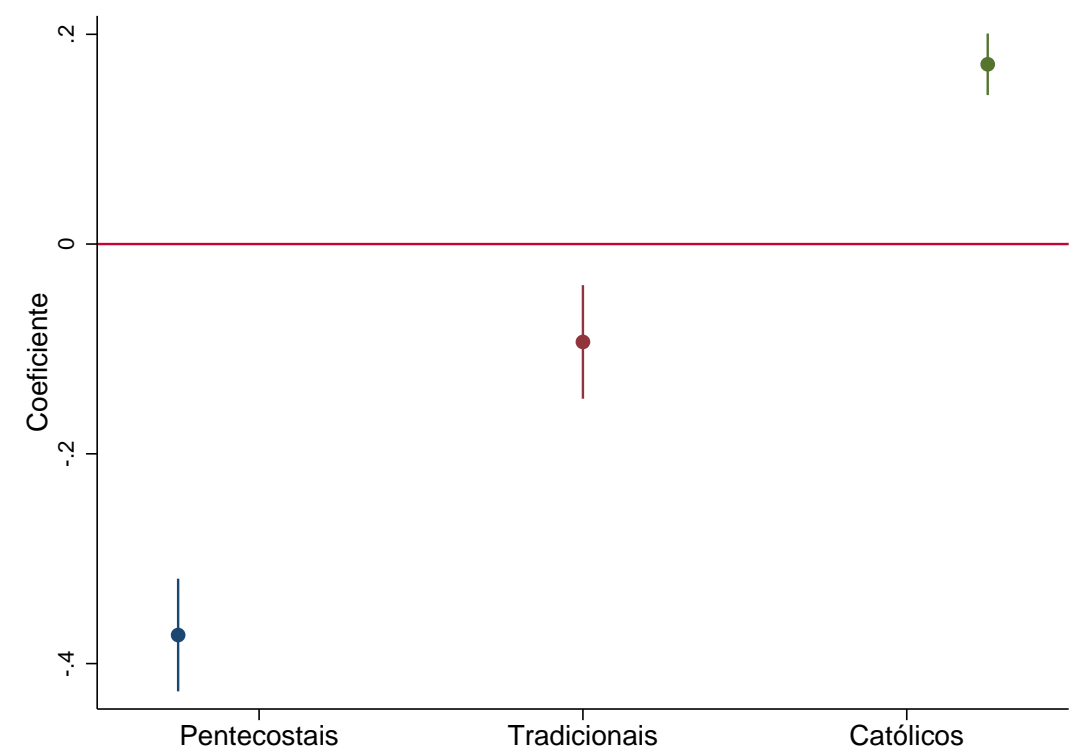

Nota: elaborado pelo autor a partir dos dados do Estudo do Instituto Brasileiro de Geografia e Estatística (IBGE) e do Tribunal Superior Eleitoral (TSE). A unidade de análise é o município $(\mathrm{N}=5,565)$. Os modelos de mínimos quadrados ordinários apresentados na figura 15 foram ajustados com erros clusterizados no nível do município. As seguintes covariáveis foram utilizadas: taxa de analfabetismo, taxa de pobreza, renda per capita, índice de desigualdade medido pelo coeficiente de Gini, índice de desenvolvimento humano (IDH) e um variável que indica a região de cada município.

É também razoável supor que os eleitores pentecostais são mais avessos à redistribuição de renda. Neste caso, a predileção pela direita nas urnas seria explicada pela simples rejeição à agenda redistributiva, contrariando o argumento de que se trata de uma consequência do conservadorismo moral. Por exemplo, se frequentar cultos religiosos conecta os indivíduos a redes alternativas de proteção social, os eleitores pentecostais poderiam ter menos incentivos para votar por redistribuição, dado que os membros deste grupo são aqueles que mais frequentam cultos religiosos (ver figura 5).

A figura 16 reporta a probabilidade de um indivíduo concordar com a afirmação de que o governo deveria tomar medidas para reduzir as diferenças entre os níveis de renda de acordo com sua filiação religiosa. As estimativas para os três grupos religiosos são estatisticamente não significantes (ou presumivelmente iguais a zero) ao nível de 
Figura 16 - Preferência por redistribuição por filiação religiosa (2014)

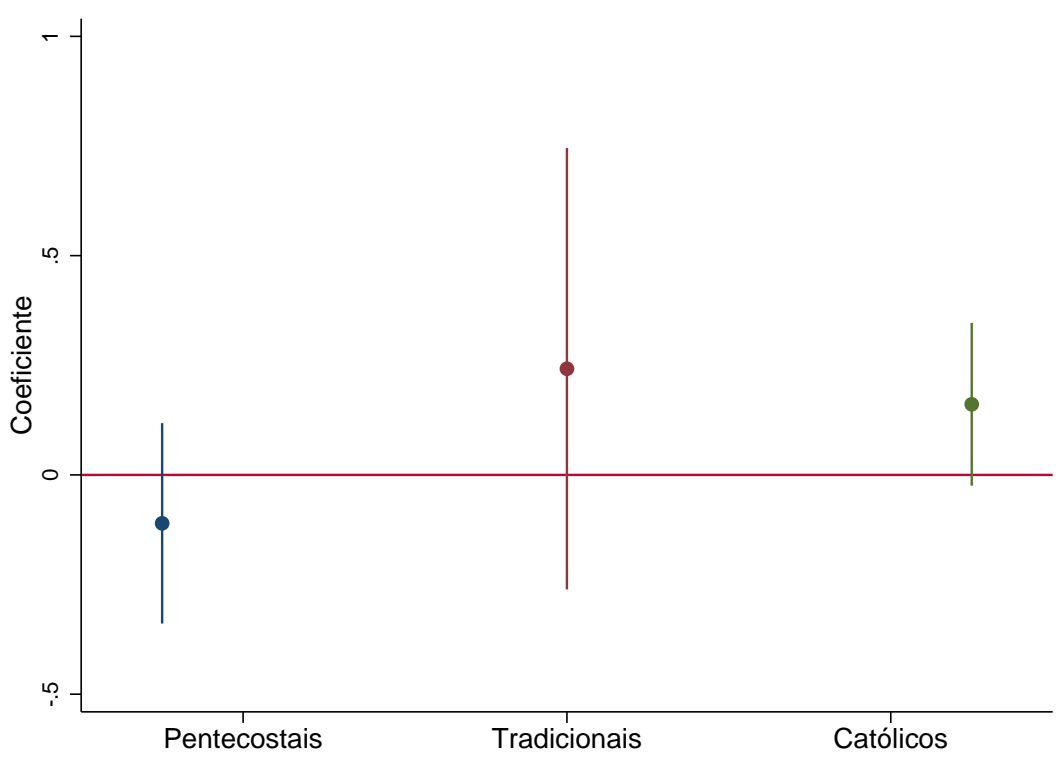

Nota: elaborado pelo autor a partir dos dados do Estudo Eleitoral Brasileiro (ESEB, 2014). A unidade de análise é o indivíduo $(\mathrm{N}=3,049)$. A seguinte pergunta foi utilizada para mensurar a preferência dos indivíduos por redistribuição: O quanto o(a) sr(a) concorda com a seguinte afirmação "O governo deveria tomar medidas para reduzir as diferenças entre os níveis de renda". $\mathrm{O}(\mathrm{a}) \mathrm{sr}(\mathrm{a})$ diria que concorda totalmente, concorda em parte, nem concorda nem discorda, discorda em parte ou discorda totalmente? A figura 16 utiliza a categoria concorda totalmente como referência. Os modelos de regressão logística foram ajustados com erros padrões robustos, utilizando os seguintes controles: idade, sexo, renda, escolaridade, raça, status ocupacional, percepção da economia, preferência partidária, região, frequência à igreja e uma variável que indica se o indivíduo é um beneficiário do Programa Bolsa Família.

95\%, o que sugere pouca variação entre os diferentes grupos religiosos. Na média, indivíduos de filiação evangélica pentecostal não são menos propensos a concordar com a diminuição das diferenças de renda quando comparados aos indivíduos evangélicos tradicionais ou católicos. É possível, no entanto, que essas estimativas sejam afetadas por social desirability, a tendência dos entrevistados fornecerem respostas que sejam socialmente mais aceitas e que sinalizam solidariedade com outros indivíduos. Arretche e Araújo (2017) estimam uma elevada aceitação à ideia de que o Estado deve empreender esforços para diminuir a desigualdade de renda no Brasil ${ }^{22}$. De acordo com os autores, o nível de concordância com esta afirmação tende a ser superior a $80 \%$ mesmo entre os indivíduos situados nas faixas de renda mais elevadas. Portanto, as estimativas

22 Para tanto, os autores utilizam pesquisas de opinião em diferentes pontos no tempo $(2008,2010,2013$ e 2014) com representatividade para todo o território brasileiro. 
reportadas na figura 16 devem ser consideradas com cautela.

Em suma, as evidências deste capítulo retratam um pior desempenho eleitoral do PT entre os "evangélicos", mas esta categoria esconde heterogeneidades importantes. A forte rejeição dos evangélicos pentecostais aos candidatos petistas contrasta com uma tendência de apoio entre os eleitores evangélicos tradicionais, embora os resultados para este último grupo sejam menos consistentes. Entre 2002 e 2018, a maior fonte de votos para o PT foi o eleitorado católico. O processo de transição religiosa também parece ter sido decisivo nas eleições presidenciais. Entre 2010 e 2018, o PT enfrentou mais dificuldades para ampliar sua base eleitoral nos municípios com maioria evangélica pentecostal. Além disso, nos municípios onde a transição religiosa estava completa em 2010, os dados revelam pior performance eleitoral do PT nas eleições de 2010, 2014 e 2018. 


\section{A religião e seus efeitos de vizinhança}

\subsection{Religião e voto: uma abordagem espacial}

Em geral, variáveis socioeconômicas não são aleatoriamente distribuídas. O crime, por exemplo, tende a ser circunscrito às áreas mais pobres com menor presença do Estado. Polos industriais costumam se desenvolver em locais mais urbanizados e com melhor infraestrutura. Identificar áreas de concentração é importante porque nos permite calcular potenciais efeitos de vizinhança (spillovers effects) dessas variáveis. Mapear áreas com alta concentração de crime permite identificar quais são as regiões vizinhas potencialmente afetadas pelas externalidades negativas do crime. Da mesma forma, ter uma referência espacial dos setores produtivos torna possível estimar os efeitos do desenvolvimento sobre municípios e territórios vizinhos.

Análises de nível agregado, por exemplo utilizando municípios, costumam assumir que as unidades de análise são independentes entre si. Isto é, o fato de haver maior concentração de evangélicos pentecostais em um dado município não afeta a probabilidade de haver mais indivíduos filiados a este mesmo grupo nos municípios vizinhos. Porém, no mundo real, existe uma conexão direta entre as duas coisas. Análises de autocorrelação espacial, também denominadas análises de clusteres, permitem mapear e estimar os efeitos desse tipo de relação de vizinhança.

As análises de clusteres podem tanto adotar medidas de concentração global quanto medidas locais de autocorrelação. No primeiro caso, indicadores de autocorrelação global, como os da família Moran (ANSELIN, 1995), são utilizados para analisar 
padrões de interdependência entre regiões e testar o grau de correlação mútua entre regiões vizinhas. Medidas de concentração local, por seu turno, permitem mapear padrões localmente heterogêneos mesmo quando uma autocorrelação global não é detectada.

Neste capítulo, utilizo medidas de autocorrelação espacial local para medir se um município e seus vizinhos são espacialmente conectados ao ponto de conformar um cluster. Isso permite, em primeiro lugar, analisar precisamente se nos clusteres católicos ou evangélicos o PT recebe mais ou menos votos. Em segundo lugar, permite estimar modelos econométricos que consideram essa dimensão espacial a partir de ajustes autorregressivos espaciais.

\subsection{A religião e seus padrões de concentração espacial}

Plotar a distribuição de uma variável no espaço é a forma mais intuitiva de testar se regiões são espacialmente dependentes. Neste caso, a variável de interesse é a religião, ou, mais precisamente, a proporção de indivíduos que se declaram filiados a uma determinada religião. Para tanto, utilizo o indicador sintético $\operatorname{Getis}-\operatorname{OrdG}_{i}^{*}(\boldsymbol{d})$ proposto por (GETIS; ORD, 2010).

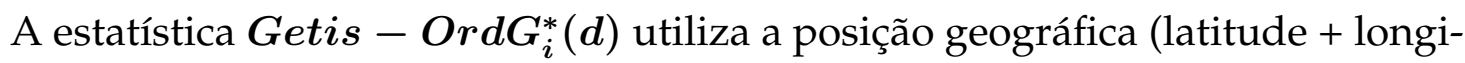
tude) de cada unidade territorial para calcular a probabilidade de duas regiões vizinhas serem espacialmente correlacionadas. Para os fins deste trabalho, a unidade geográfica é o município e a hipótese nula é que dois municípios vizinhos são independentes (i.e. não são espacialmente correlacionados). Utilizo o algoritmo proposto por Kondo (2016) para construir uma matriz de contiguidade tendo como referência os 5,565 municípios brasileiros que existiam em 2010. 
Figura 17 - Mapa de calor da distribuição evangélica pentecostal no Brasil



Nota: elaborado pelo autor a partir dos dados do Estudo do Instituto Brasileiro de Geografia e Estatística (IBGE) e do Tribunal Superior Eleitoral (TSE). A unidade de análise é o município ( $\mathrm{N}=5,565)$. Mapa

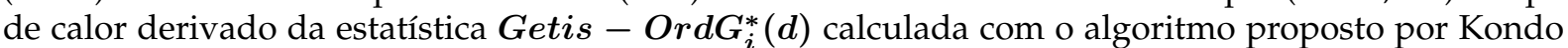
(2016). Tons mais escuros de vermelho significam alta probabilidade ( $p$-value próximo de zero) de autocorrelação espacial, enquanto as áreas mais claras significam baixa probabilidade ( $p$-value próximo de 1) de autocorrelação espacial. 
A figura 17 informa a distribuição das probabilidades de autocorrelação da religião evangélica pentecostal no território brasileiro. Por exemplo, nas áreas urbanas situadas no litoral brasileiro e nos estados da região Norte o $p$-value que corresponde à probabilidade de autocorrelação espacial local é muito próximo de zero - o que significa que podemos rejeitar a hipótese nula de independência entre os municípios vizinhos. Uma forma menos técnica e mais intuitiva de interpretar os resultados do mapa é simplesmente focar na intensidade das cores. Tons mais escuros de vermelho significam alta probabilidade ( $p$-value próximo de zero) de autocorrelação espacial, enquanto as áreas mais claras significam baixa probabilidade ( $p$-value próximo de 1 ) de autocorrelação espacial.

O mapa de calor da distribuição evangélica tradicional informa um padrão distinto de autocorrelação espacial local. De acordo com a figura 18, os evangélicos tradicionais estão concentrados na região Sul e na faixa do litoral que liga os estados de Rio de Janeiro e São Paulo. Por outro lado, clusteres de autocorrelação espacial são mais raros nas regiões Norte e Nordeste.

Em geral, assumimos uma hipótese de independência entre as unidades quando ajustamos modelos lineares de regressão. Por exemplo, nos modelos econométricos de nível agregado (município), reportados no capítulo 2, consideramos que os resíduos de cada município não são correlacionados com os resíduos de seus vizinhos. Mas os mapas de calor apresentados neste capítulo indicam que essa pressuposição pode não ser válida ${ }^{1}$.

É possível realizar esse teste regredindo a proporção de votos válidos do PT em função da proporção de católicos e evangélicos pentecostais e tradicionais. O passo

$\overline{1}$ O mapa de calor da distribuição de católicos no território brasileiro é reportado no Apêndice D. 
Figura 18 - Mapa de calor da distribuição evangélica tradicional no Brasil

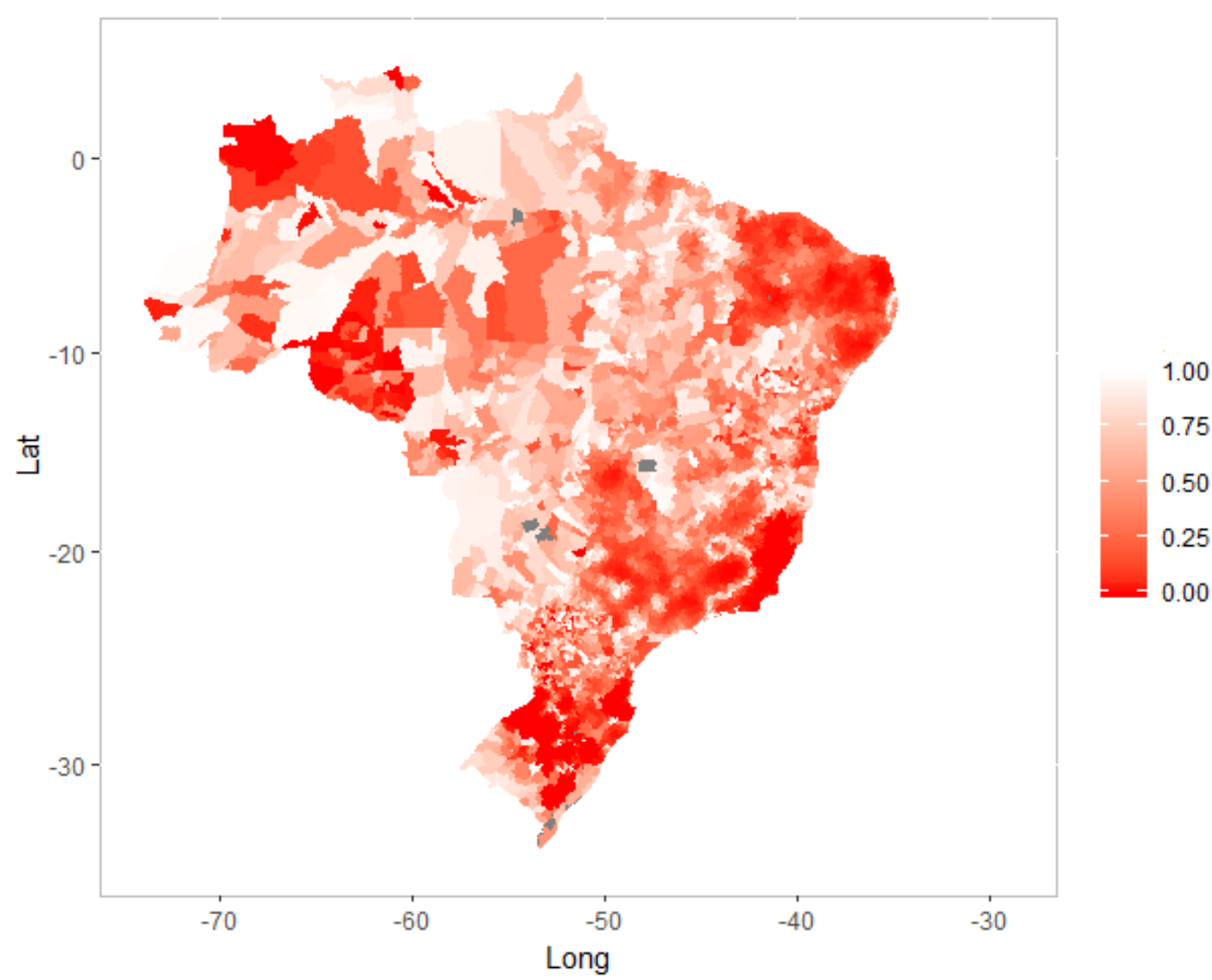

Nota: elaborado pelo autor a partir dos dados do Estudo do Instituto Brasileiro de Geografia e Estatística (IBGE) e do Tribunal Superior Eleitoral (TSE). A unidade de análise é o município ( $\mathrm{N}=5,565)$. Mapa

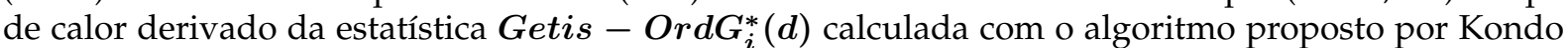
(2016). Tons mais escuros de vermelho significam alta probabilidade ( $p$-value próximo de zero) de autocorrelação espacial, enquanto as áreas mais claras significam baixa probabilidade ( $p$-value próximo de 1) de autocorrelação espacial. 
seguinte é utilizar uma matriz de contingência com informações dos 5,565 municípios para testar a dependência espacial em cada um dos casos. A tabela 3 mostra o teste Moran de dependência espacial tomando as eleições de 2010 como exemplo. Em particular, o teste considera a hipótese nula de que os resíduos de cada município não são correlacionados com seus vizinhos. Os resultados permitem rejeitar a hipótese nula em favor da hipótese alternativa de que os resíduos são correlacionados com seus vizinhos (IC de 99\%).

Tabela 3 - Correlação entre religião e proporção de votos do PT nas eleições presidenciais de 2010

\begin{tabular}{lccc}
\hline \hline & $(1)$ & $(2)$ & $(3)$ \\
& PT $(2010)$ & PT (2010) & PT (2010) \\
\hline Pentecostais & $-0.114^{* * *}$ & & \\
Tradicionais & $(-4.46)$ & & \\
& & $0.0988^{* * *}$ & \\
Católicos & & $(3.43)$ & $0.0290^{*}$ \\
& & & $(2.25)$ \\
$\begin{array}{l}\text { Dependência espacial (Moran) } \\
\text { chi2(1) }\end{array}$ & 107.29 & 121.02 & 117.83 \\
Prob $>$ chi2 & 0.0000 & 0.0000 & 0.0000 \\
\hline Observações & 5565 & 5565 & 5565 \\
\hline \hline
\end{tabular}

Estatística $t$ entre parênteses.

${ }^{*} p<0.05,{ }^{* *} p<0.01,{ }^{* * *} p<0.001$

Nota: elaborado pelo autor a partir dos dados do Estudo do Instituto Brasileiro de Geografia e Estatística (IBGE) e do Tribunal Superior Eleitoral (TSE). A unidade de análise é o município ( $\mathrm{N}=5,565)$. As seguintes covariáveis foram utilizadas: taxa de analfabetismo, taxa de pobreza, renda per capita, índice de desigualdade medido pelo coeficiente de Gini e índice de desenvolvimento humano (IDHM).

Em outras palavras, os resultados da tabela 3 mostram efeitos de vizinhança da variável religião, o que significa que a distribuição de católicos e evangélicos no território brasileiro não é aleatória. A priori, isso não invalida os resultados do capítulo 2, mas sugere efeitos indiretos da variável religião que podem ser capturados apenas por meio de modelos de autocorrelação espacial. 


\subsection{Modelos de autocorrelação espacial}

Modelos de autocorrelação espacial (MAE) são modelos econométricos que incluem defasagens de tempo e espaço para estimar os efeitos de vizinhança de uma variável de interesse sobre o fenômeno investigado (DARMOFAL, 2015; DRUKKER; EGGER; PRUCHA, 2013). Formalmente, a versão sintética de um MAE pode ser escrita da seguinte forma:

$$
Y=x_{0}+x_{1} W y+e
$$

Onde $\boldsymbol{W}$ é uma matriz de contigência que sintetiza o relacionamento espacial entre áreas, e $\boldsymbol{y}$ mede potenciais efeitos de vizinhança (spillovers). Os elementos de $\boldsymbol{W}_{\boldsymbol{i 1 i \boldsymbol { 2 }}}$ espeficam qual o nível da relação de vizinhança entre uma área $\boldsymbol{i}_{1}$ e $\boldsymbol{i}_{2}$. $\boldsymbol{W}_{\boldsymbol{i 1 i 2}}$ é zero se $\boldsymbol{i}_{2}$ não tem qualquer efeito sobre $\boldsymbol{i}_{1}$. Quanto maior o efeito de vizinhança, maior $\boldsymbol{W}_{\boldsymbol{i 1} \boldsymbol{i} \mathbf{2}}$.

Substantivamente, um MAE permite estimar, por exemplo, o quanto a proporção de evangélicos pentecostais em um dado município afeta a proporção de votos do PT no município vizinho. Posto de forma simples, um modelo de autocorrelação espacial permite responder a seguinte questão: espaços territorias dominados (clusterizados) pelo pentecostalismo afetam negativamente a votação do PT?

Formalmente, estimo a seguinte equação:

$$
Y_{u e}=x_{0}+x_{1} x_{c r}+x_{2} W x_{c r}+e
$$

Onde $\boldsymbol{x}_{\mathbf{2}} \boldsymbol{W} \boldsymbol{x}_{\boldsymbol{c} r}$ refere-se à defasagem espacial da variável independente de interesse, neste caso, a variável religião. Este modelo permite captar, tanto o efeito direto 
(intramunicípio) da variável religião, quanto seu efeito indireto (entre municípios) produzido por potenciais spillovers. Além disso, torna possível saber qual a contribuição de cada um desses efeitos para o efeito total da variável religião sobre a votação do PT.

\subsection{Efeitos de vizinhança da variável religião}

A figura 19 reporta os resultados do MAE de acordo com o grupo religioso. Os resultados também foram desagregadas por eleições e por tipo de efeito (diretos e indiretos). Nos municípios com maioria pentecostal, existe um claro padrão de rejeição aos candidatos do PT nas eleições de 2010, 2014 e 2018², confirmando as estimativas de nível agregado reportadas no capítulo 2. Mas os resultados também revelam um consistente efeito indireto nas áreas onde os municipíos formam clusteres de concentração pentecostais. Nestes locais, a votação no PT foi, na média, 0.15 ponto percentual menor em todas as eleições presidenciais entre 2006 e 2018.

As estimativas referentes ao grupo evangélico tradicional revelam efeitos diretos mistos, resultado também em conformidade com as evidências do capítulo 2. Todavia, os efeitos indiretos são positivos e consistentes ao longo do tempo. Na média, nas áreas com alta concentração evangélica tradicional, a votação do PT foi 0.20 ponto percentual maior entre 2010 e $2014^{3}$.

As estimativas para o grupo dos católicos confirmam os efeitos diretos discutidos no capítulo 2. A votação do PT tende a ser maior nos municípios com maioria católica. Entre 2010 e 2018, um acréscimo de 1 ponto percentual na população católica significou um aumento de cerca de 0.18 ponto percentual na votação do PT. As estimativas também

2 A estimativa não é estatisticamente significante para a eleição de 2006.

3 A estimativa para a eleição de 2006 é estatisticamente não significante e presumivelmente zero. 
Figura 19 - Efeitos diretos e indiretos da variável religião sobre o voto no PT nas eleições presidenciais (2006-2018)
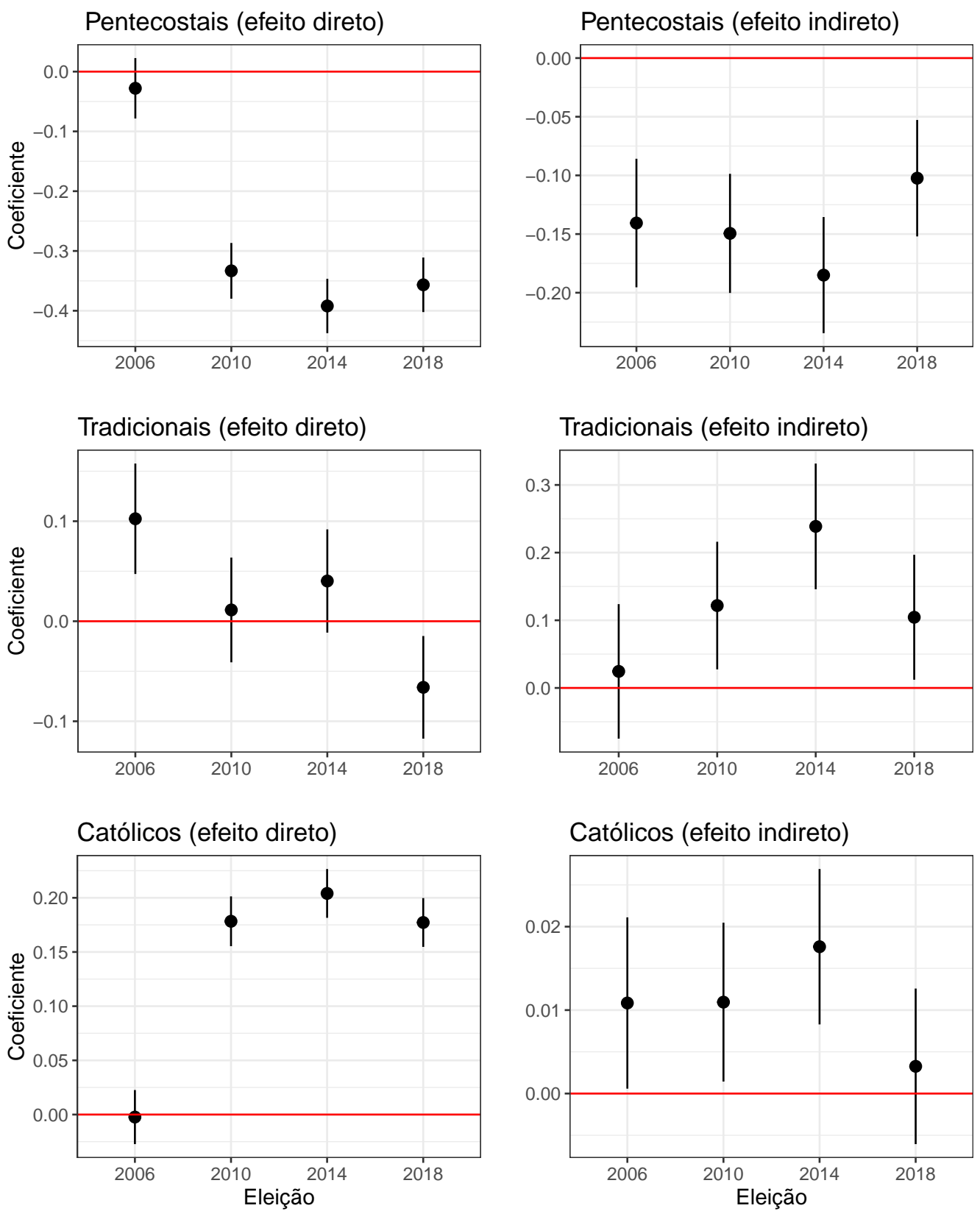

Nota: elaborado pelo autor a partir dos dados do Estudo do Instituto Brasileiro de Geografia e Estatística (IBGE) e do Tribunal Superior Eleitoral (TSE). A unidade de análise é o município ( $\mathrm{N}=5,565)$. Efeito direto $=$ intramunicípio. Efeito indireto = entre municípios. Os modelos de autocorrelação espacial foram estimados com um generalized method-of-moments utilizando as seguintes covariáveis: taxa de analfabetismo, taxa de pobreza, renda per capita, índice de desigualdade medido pelo coeficiente de Gini, índice de desenvolvimento humano (IDH) e proporção de beneficiários do Bolsa Família no município. 
indicam efeitos de vizinhança associados ao aumento da votação do PT, mas esses efeitos são substantivamente pequenos e não parecem ter sido decisivos nas eleições presidenciais entre 2006 e $2018^{4}$.

Em suma, os resultados deste capítulo confirmam os resultados do capítulo 2, mas fornecem indícios de efeitos indiretos da variável religião pouco explorados pela literatura. As evidências parecem indicar que os efeitos de vizinhança são mais fortes nas áreas de predominância pentecostal. O que significa que o apoio eleitoral ao PT nos clusteres católicos não é compensado pela forte rejeição ao partido nas áreas clusterizadas pelos pentecostais. Na contramão de seus pares pentecostais, os efeitos de vizinhança nas áreas com grande concentração de evangélicos tradicionais indicam baixa rejeição ao PT nas eleições presidenciais brasileiras.

4 O maior efeito foi observado nas eleições de 2014, quando o acréscimo de 1 ponto percentual na população católica significou um aumento de cerca de 0.02 ponto percentual na votação do PT. 


\section{Moralismo como Estratégia Eleitoral}

\subsection{Brasil acima de tudo, Deus acima de todos}

Imagine uma situação em que o candidato declara dias antes do segundo turno das eleições presidenciais: "juntos e com muita fé em Deus, iremos reconstruir o Brasil". Na mesma semana, um dos líderes da maior denominação pentecostal do Brasil revela publicamente: "a tendência do povo evangélico é não votar em candidatos das esquerdas, mas num cristão. No primeiro turno havia muita confusão, mas agora nosso povo sabe muito bem em quem votar". Passadas as eleições e confirmada a vitória do candidato de direita, o líder pentecostal volta a se manifestar: "não podemos negar, quem o elegeu foram os evangélicos. A vitória dele veio da Assembleia de Deus".

A despeito da coincidência com o contexto eleitoral vivido em 2018, as falas acima se referem às eleições de 1989. O candidato em questão é Fernando Collor (Partido da Reconstrução Nacional, $\mathrm{PRN})^{1}$, primeiro presidente eleito via eleições diretas após 21 anos de ditadura militar no Brasil. O pastor é José Wellington, naquele momento, presidente da Convenção Geral das Assembleias de Deus no Brasil (CGADB). Os trechos acima, originalmente publicados por Mariano e Pierucci (1992) para mostrar o envolvimento dos pentecostais na eleição de Collor, retratam uma constante nas eleições presidenciais brasileiras: a oposição majoritária do segmento evangélico pentecostal aos candidatos de esquerda.

"Pedirei votos para qualquer candidato que dispute com Lula no segundo turno",

1 Em 1990, o PRN foi rebatizado como Partido Trabalhista Cristão (PTC), nome adotado até os dias de hoje. 
afirmou o pastor e Deputado Federal da Igreja Assembleia de Deus, Salatiel Carvalho, em entrevista concedida à Folha de São Paulo em 12 de Junho de $1994^{2}$. A narrativa de que os evangélicos sofreriam perseguição religiosa caso o PT vencesse as eleições de 1994 ganhou contornos diferentes ao longo dos anos ${ }^{3}$. Em 2002, a candidatura de Anthony Garotinho, então governador do Rio de Janeiro e declaradamente evangélico, contou com a adesão de 51,3\% dos evangélicos em uma eleição marcada por um discurso em defesa da família (FONSECA, 2002). Em 2006, mesmo após sucessivas tentativas de acordo com os grupos evangélicos para sua reeleição, a Convenção Nacional das Assembleias de Deus (CONAMAD) decidiu apoiar o principal adversário de Lula, Geraldo Alckmin (PSDB), na disputa presidencial (SOUZA, 2013).

Nas eleições de 2010, a liderença mais midiática da Igreja Assembleia de Deus, pastor Silas Malafaia, defendeu publicamente o voto contra a candidata petista Dilma Rousseff por esta ter declarado apoio ao Projeto de Lei 122 que instituia a criminalização da homofobia (ORO; MARIANO, 2010). Em 2014, o aborto foi um tema fundamental e à esquerda foi atribuido o plano de acabar com a família cristã brasileira (CUNHA; LOPES; LUI, 2017). Nas eleições mais recentes, em 2018, o candidato petista Fernando Haddad foi acusado de planejar instaurar uma "ditadura de gênero" e "gayzista" na sociedade brasileira ${ }^{4}$.

Movidos por convicções religiosas ou por mera conveniência eleitoral ${ }^{5}$, as can-

2 Jornal Folha de São Paulo. Quércia e Lula disputam voto evangélico. Disponível em: https: / / www1.folha.uol.com.br/fsp/1994/6/12/brasil/32.html. Acesso em: 18 mai. 2019.

3 Como discutem Pierucci e Prandi (1995), nas eleições presidenciais de 1994, a campanha do então candidato Luiz Inácio Lula da Silva teve que se empenhar para afastar os rumores de que, caso eleito, o candidato petista ordenaria o fechamento das igrejas evangélicas no Brasil.

4 No dia 06 de Outubro, um dia antes do primeiro turno das eleições de 2018, a Justiça Eleitoral determinou a retirada de 35 notícias falsas (fake news) até então veiculadas em diversas redes sociais. Dentre elas, uma foto de uma mamadeira erótica que seria distribuída em escolas caso o candidato petista fosse eleito e uma foto de Manuela D'Ávila, candidata à vice-presidente na chapa petista, vestindo uma blusa com o escrito "Jesus é Travesti".

5 O ex-Deputado e líder da Câmara dos Deputados Eduardo Cunha contava com apoio da Igreja Assembleia de Deus no estado do Rio de Janeiro. Porém, nunca esteve formalmente ligado às atividades 
didaturas vinculadas às igrejas podem se beneficiar de uma ampla rede de apoio. $\mathrm{O}$ trabalho de mobilização nas igrejas está por trás do barateamento das campanhas eleitorais dos candidatos evangélicos em eleições legislativas (NETTO; SPECK, 2017) ${ }^{6}$ e do expressivo aumento da bancada evangélica no Congresso Nacional (BOAS, 2014; MACHADO; BURITY, 2014; LACERDA, 2018; MACHADO, 2018; RODRIGUES-SILVEIRA; CERVI, 2019). No entanto, pastores e lideranças pentecostais também desempenham um importante papel de mobilização eleitoral nas eleições presidenciais brasileiras.

\subsection{Os pastores como brokers}

Existe uma extensa literatura na Ciência Política que investiga as estratégias utilizadas pelos partidos para mobilizar eleitores em contextos de alta vulnerabilidade social e baixa identificação partidária ${ }^{7}$. O trabalho de Stokes (2005) contribui nesse sentido ao mostrar as redes locais de apoio político (Machine politics networks) que se articulam com o objetivo de mobilizar os eleitores de baixa renda via compra de votos. De acordo com a autora, lideranças nacionais transferem para os seus cabos eleitorais, também conhecidos como brokers, recursos para angariar votos nos redutos eleitorais onde estes últimos possuem um amplo conhecimento sobre as demandas da população local.

Análises posteriores ressaltam as nuances desse processo ao mostrar, por exemplo, que o trabalho dos brokers não se restringe à compra de votos, mas também abrange

da Igreja. O então pré-candidato Jair Bolsonaro aceitou ser batizado por um pastor evangélico para angariar apoio entre os eleitores desse grupo. O Batismo foi realizado em 2016 no Rio Jordão, em Israel, enquanto a votação do impeachment de Dilma Rousseff ocorria no Senado Federal (ALMEIDA, 2017).

6 De acordo com os autores, o menor gasto nas campanhas eleitorais dos candidatos evangélicos pode ser explicado pela mobilização do capital simbólico nas igrejas evangélicas.

7 Para uma revisão exaustiva dessa literatura, ver Golden e Min (2013). 
o transporte de eleitores para os locais de votação (NICHTER, 2008) e a captação de eleitores para votar em outros domicílios eleitorais (HIDALGO; NICHTER, 2016). Os brokers podem, ainda, assumir a forma de políticos locais (Prefeitos ou Vereadores) que atuam para conseguir votos para seus parceiros políticos nas disputas de nível estadual ou nacional (AVELINO; BIDERMAN; BARONE, 2012; LIMONGI, 2015; NOVAES, 2018).

Holland e Palmer-Rubin (2015) introduzem o conceito de Organizational brokers, cabos eleitorais que representam interesses coletivos específicos e são os responsáveis por negociar com políticos e partidos o apoio eleitoral do grupo ao qual representam. Esta distinção analítica é importante porque nos permite entender o trabalho de mobilização dos Brokers quando não há necessidade de compra de votos. No interior das igrejas pentecostais, os pastores são capazes de mobilizar o eleitorado de baixa renda utilizando argumentos morais, sem a necessidade de compra de votos, pelo menos não nos termos que a literatura costuma tratar o fenômeno.

Nas eleições presidenciais de 2018, o pastor Silas Malafaia, um dos maiores líderes pentecostais no Brasil, ajudou a promover a campanha de Jair Bolsonaro (Partido Social Liberal, PSL), candidato de extrema direita, contra o então candidato petista Fernando Haddad ${ }^{8}$. Silas, como é conhecido no meio pentecostal, atuou durante toda a campanha para relacionar a candidatura petista à degeneração dos valores morais fundamentais para os cristãos evangélicos. No dia 1 de outubro de 2018, seis dias antes do primeiro turno das eleições presidenciais, utilizou sua conta no Twitter ${ }^{9}$, com 1,4 milhão de seguidores, para denunciar a natureza imoral dos partidos de esquerda: "Para o PT e o PSOL, os pais não têm autoridade sobre as crianças, típico de comunistas".

8 Antes disso, Silas Malafaia apoiou e fez campanha publicamente para Geraldo Alckmin (2006), José Serra (2010) e Aécio Neves (2014).

9 Todos os tweets reportados neste capítulo foram acessados por meio da ferramenta de busca avançada do Twitter. https://twitter.com/search-advanced. A pesquisa foi realizada entre os dias 22 e 24 de junho de 2019. 
Uma postagem no dia 3 de outubro segue a mesma linha: “Atribuem aos evangélicos, grande parte da queda de Haddad. Vocês estão equivocados! É a sociedade brasileira como um todo, que abriu os olhos e sabe que vocês representam a corrupção, destruição da família, erotizar crianças em escolas etc".

Antes do segundo turno das eleições, houve novos esforços do pastor pentecostal para mobilizar seus seguidores utilizando pautas moralizantes. "Haddad representa o PT que é a favor de crianças mudarem de sexo sem consentimento dos pais, ideologia de gênero para perverter crianças nas escolas, produziu a maior roubalheira da história do Brasil, o próprio Haddad tem mais de 30 processos contra ele. FORA PT ! FORA HADDAD ${ }^{10}$ !", postou o líder pentecostal em 24 de Outubro. Um dia depois, nova postagem, desta vez fundamentando sua posição com elementos bíblicos: “Mais tarde vou postar um vídeo, provando na Bíblia, que Haddad se utiliza da mesma tática que o diabo usou para tentar derrotar Jesus. MESMO Q VOCÊ NÃO ACREDITE NA BÍBLIA, VOCÊ VAI FICAR DE BOCA ABERTA COM O QUE VOU TE MOSTRAR. AGUARDE!". Em 28 de Outubro, dia do segundo turno das eleições, a mensagem final: “HOJE! EM NOME DE JESUS! A verdade vai prevalecer contra a mentira, cinismo, corrupção, destruição dos valores morais, sexualizar crianças, liberação de drogas e outros tantos lixos morais. O BRASIL É DO SENHOR JESUS!".

\subsection{A mobilização eleitoral nas igrejas pentecostais}

O alcance do engajamento virtual das lideranças pentecostais é modesto perto da ampla rede de mobilização formada pelas igrejas pentecostais com capilaridade em todo o território nacional e influência sobre milhões de eleitores de baixa renda. É nos

10 As palavras em caixa alta foram postadas desta forma pelo autor no Twitter. Optei por manter o formato para preservar a autenticidade das falas. 
cultos que os pastores podem fazer uso de sua posição institucional para influenciar o voto de uma massa de fiéis disposta a seguir a liderança espiritual de suas referências eclesiásticas. A mobilização pode ocorrer de maneira indireta, quando pastores associam determinadas candidaturas (sem explicitamente revelar seu posicionmento eleitoral) a forças opressoras e malignas, ou assumir uma forma mais direta, quando esses mesmos líderes revelam sinais e orientações divinas para votar em um determinado candidato $(\text { VALLE, 2018) })^{11}$.

Em que medida o engajamento eleitoral das lideranças pentecostais afeta o voto dos indivíduos que frequentam essas igrejas? Idealmente, essa pergunta poderia ser respondida por meio de um experimento controlado onde indivíduos com características semelhantes receberiam diferentes estímulos morais. Com uma amostra grande o suficiente, seria possível desagregar os resultados por diferentes grupos religiosos e testar a hipótese de que os indivíduos com filiação pentecostal seriam mais reativos a estes estímulos.

Uma abordagem alternativa seria tentar captar o efeito espacial da mobilização eleitoral promovida pelas igrejas pentecostais. Desse modo, seria possível testar se a votação dos candidatos de esquerda nas eleições presidenciais tende a ser menor quando existem igrejas pentecostais perto dos locais de votação. Existem dois principais desafios para implementar essa estratégia empírica. O primeiro deles é conseguir a lista de todos os locais de votação existentes no Brasil. De posse da lista, é preciso ainda verificar a confiabilidade dos endereços existentes. O segundo desafio é conseguir uma lista de endereços de todas as igrejas pentecostais em operação no Brasil. Porém, ao contrário

11 Em 1989, o Pastor Manuel Ferreira, da Igreja Assembleia de Deus, declarou ao Jornal do Brasil: "Após orar e pedir a Deus que indicasse uma pessoa, o Espírito Santo nos convenceu de que Fernando Collor era o escolhido". 
da Igreja Católica, as igrejas evangélicas não adotam uma estrutura centralizada que permita coletar todas as informações de uma única fonte.

Neste trabalho, realizo um exercício exploratório utilizando o estado do Rio de Janeiro (RJ) como um caso para estimar os efeitos espaciais do engajamento eleitoral das lideranças pentecostais. Dentre os estados brasileiros com maior número de eleitores ${ }^{12}$, esta é a Unidade da Federação mais avançada no processo de transição religiosa e com grande concentração de evangélicos pentecostais nas áreas periféricas (ALVES; CAVENAGHI; BARROS, 2014). Para tanto, faço uso dos dados do projeto "Como votou sua vizinhança", implementado durante as eleições presidenciais de 2018 pelo jornal Estadão ${ }^{13}$. Para oferecer aos seus leitores a possibilidade de verificar como os candidatos ao cargo de Presidente da República foram votados no nível local, uma equipe de cientistas de dados organizou as listas de endereços e georrefenciou todos os locais de votação no Brasil passíveis de busca no Google Maps ${ }^{14}$.

Para operacionalizar a variável independente, utilizo uma base de dados com todos os endereços da Igreja Assembleia de Deus Vitória em Cristo (ADVEC), uma das maiores denominações pentecostais no Brasil. Fundada em 20 de maio de 1959 e presidida desde 2010 pelo Pastor Silas Malafaia, a ADVEC possui cerca de 35 mil membros espalhados por 91 filiais na região metropolitana e em outras cidades do RJ. Como pode ser visto na figura 20, a maioria das igrejas se localiza na região metropolitana do estado, sobretudo na região Norte da cidade do Rio de Janeiro (e.g. Brás de Pina, Meier e Penha), baixada fluminense (e.g. Bonsucesso, Olaria e Ramos) e outros locais

12 De acordo com o Tribunal Superior Eleitoral (TSE), em 2018, o estado do Rio de Janeiro era o terceiro maior colégio eleitoral no Brasil com cerca de 12.5 milhões de eleitores.

13 Os dados estão disponíveis no seguinte endereço: https://github.com/estadao/como-votou-suavizinhanca.

14 Alguns locais de votação em áreas de floresta, por exemplo, não foram detectados pelas imagens de satélite. 
Figura 20 - Distribuição espacial das igrejas ADVEC no estado do Rio de Janeiro (2018)

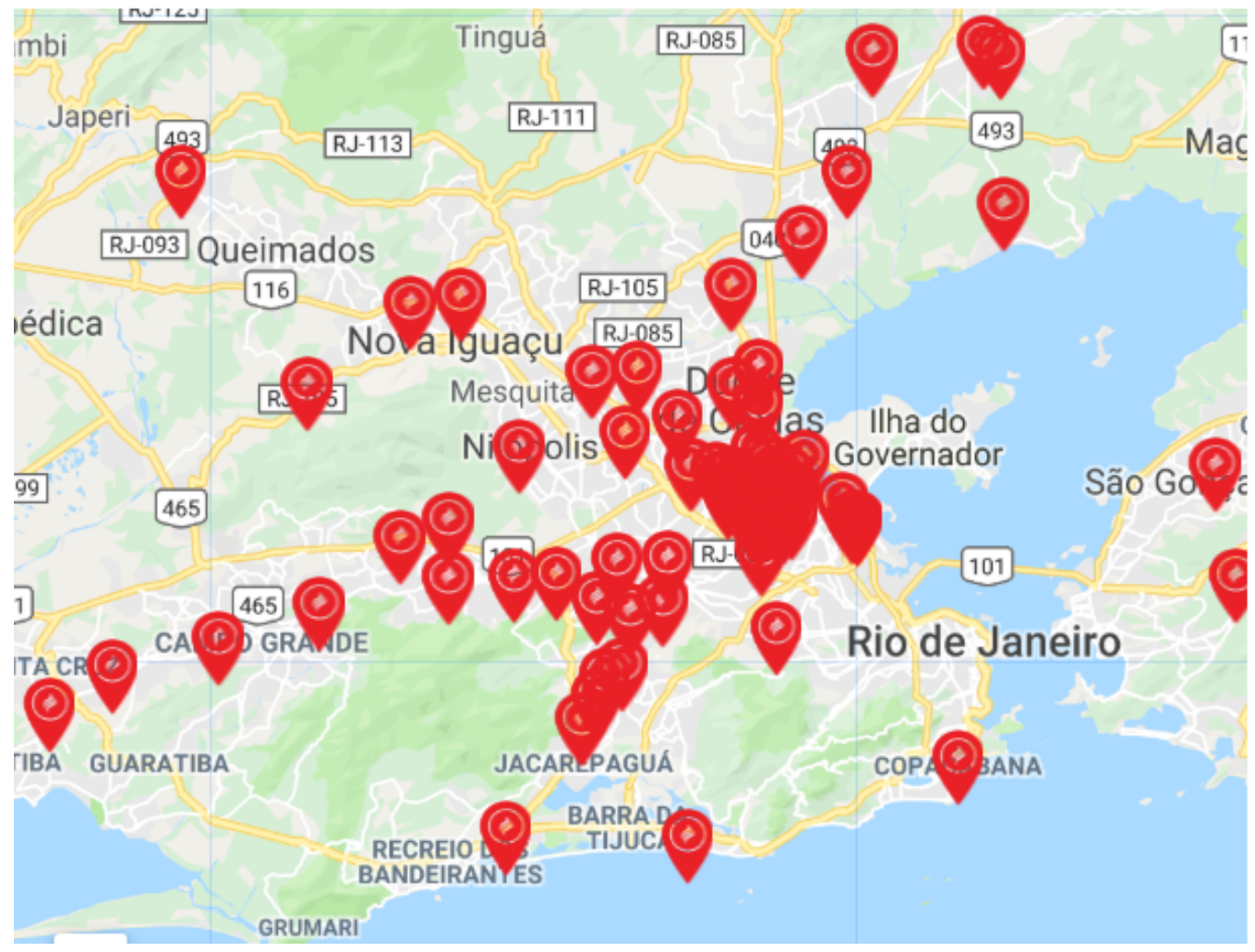

Nota: elaborado pelo autor com a ferramenta de georreferenciamento da plataforma Google Maps. A figura 20 mapeia as ADVEC localizadas no território do estado do Rio de Janeiro $(\mathrm{N}=91)$. A igreja também possui igrejas em outras 9 Unidade Federativas (SP, DF, ES, MG, PB, PE, PR, RN, e SC) e Portugal, que não foram aqui representadas.

pobres, como São Gonçalo, Pavuna e Realengo. Embora alguns poucos templos estejam localizados em bairros de classe média e alta da Zona Oeste (e.g. Barra da Tijuca, Recreio dos Bandeirantes e Taquara-Jacarepaguá) e Zona Sul (e.g. Copacabana), a distribuição territorial das ADVEC segue o padrão predominante no pentecostalismo brasileiro, que prioriza áreas urbanas periféricas com altos índices de vulnerabilidade social.

Utilizando o sistema de coordenadas do Google Maps, foram coletadas informações sobre a latitude, a longitude e o código de endereçamento postal (CEP) das 91 igrejas da ADVEC. Essas coordenadas geográficas foram utilizadas para agregar as informações de localização das ADVEC ao banco de dados com os locais de votação. O banco de dados final contém informações eleitorais para 3,652 locais de votação no RJ e 
uma variável que informa se existe uma ADVEC no mesmo CEP de um dado local de $\operatorname{votação~}^{15}$.

Tabela 4 - Descritivas dos dados referentes aos locais de votação (2018)

\begin{tabular}{lccccc}
\hline \hline Variável & Obs & Média & SD & Min & Max \\
\hline ADVEC & 3,652 & .0232 & .1508 & 0 & 1 \\
Distância $(\mathrm{Km})$ & 3,652 & 3.956 & .3122 & 1 & 4 \\
Nível educacional & 3,652 & 7.566 & 1.993 & 1.374 & 13.66 \\
Eleitores aptos & 3,652 & 364.4 & 79.79 & 50 & 567 \\
Comparecimento & 3,652 & 270.0 & 65.38 & 41 & 441 \\
Turnout & 3,652 & 73.93 & 5.959 & 47.68 & 92.85 \\
$(\%)$ PT votos válidos & 3,652 & 28.53 & 7.236 & 5.323 & 60.19 \\
\hline \hline
\end{tabular}

Nota: A unidade de análise é o local de votação $(\mathrm{N}=3,652)$. A variável Distância $(\mathrm{km})$ foi recategorizada para evitar correlação perfeita com a variável ADVEC. Sua versão categórica assume valores entre $1 \mathrm{e} 4$. A categoria 1 abrange os casos em que a ADVEC dista entre 0 e $1 \mathrm{~km}$ do local de votação, a categoria 2 entre 1 e $2 \mathrm{~km}$, a categoria 3 entre 2 e $3 \mathrm{Km}$ e a categoria 4 entre de 4 e $5 \mathrm{~km}$. Na variável "Nível educacional", quanto maior o valor, maior o nível educacional médio do local de votação.

Assumo que os eleitores tendem a votar próximo de suas residências. Essa é uma presunção válida dado que o local de moradia é o principal critério para definir a seção de votação dos eleitores no Brasil. Também assumo que os fiés das igrejas pentecostais tendem a frequentar igrejas próximas de suas casas. Enquanto isso não é passível de verificação empírica, é razoável supor que os indivíduos de baixa renda optam por frequentar igrejas próximas de seus domicílios para reduzir os custos de tempo e transporte.

Em média, as igrejas da ADVEC distam $2.2 \mathrm{~km}(\mathrm{SD}=1.5 \mathrm{Km})$ dos locais de votação, uma distância curta o suficiente para presumir que o efeito da mobilização nas igrejas pode ser observado nos dados eleitorais de nível local. Alguém pode argumentar

15 Foram excluídas as ADVEC que encontraram correspondência com locais de votação mas que estavam situadas em municípios que utilizam um único CEP para identificar todos os logradouros $(\mathrm{N}=5)$. Vale lembrar que apenas localidades com mais de 50.000 habitantes residentes na área urbana têm CEPs por logradouro (Ruas, Avenidas, Alamedas, Travessas, etc). Esse procedimento importa porque, nestes casos, a igreja pode estar situada a dezenas de quilômetros do local de votação e, portanto, não deveríamos presumir qualquer efeito espacial do pentecostalismo sobre a votação do PT. 
que, mesmo que as igrejas estejam perto dos locais de votação, o contingente de pessoas afetadas pelo pentecostalismo, em especial aqueles que frequentam a ADVEC, não seria suficiente para alterar o resultado nos locais de votação. Os dados, no entanto, não endossam essa suspeita. Se dividirmos os 35 mil membros da ADVEC espalhados pelas 91 filiais, temos um número de 384 membros por igreja, número superior à média de 364 eleitores aptos a votar em cada local de votação, como informa a Tabela 4.

Intuitivamente, testo a hipótese de que a proximidade entre as ADVEC e os locais de votação está associada ao menor suporte eleitoral ao PT nas eleições presidenciais de 2018. Formalmente, estimo a seguinte equação:

$$
Y_{i_{t}}=\beta_{0}+x_{i_{t}} \beta+v_{i}+e_{i_{t}}
$$

Onde $\boldsymbol{Y}_{i_{t}}$ mensura a proporção de votos válidos para o candidato do PT, Fernando Haddad, nas eleições de $2018, \boldsymbol{x}_{\boldsymbol{i}_{t}} \boldsymbol{\beta}$ indica se existe uma ADVEC no mesmo CEP do local de votação, $\boldsymbol{v}_{\boldsymbol{i}}$ refere-se aos efeitos fixos no nível distrito-bairro, e $\boldsymbol{e}_{\boldsymbol{i}_{t}}$ denota que as estimativas são clusterizadas no nível das zonas eleitorais para considerar a variação entre locais de votação. Como a educação dos indivíduos afeta tanto a chance de serem pentecostais, quanto a chance de votarem no PT, utilizo como controle a média de escolarização dos eleitores nos locais de votação. Outro importante controle considerado é a taxa de comparecimento eleitoral (turnout), uma vez que os evangélicos pentecostais poderiam ter maior propensão a participar do processo eleitoral. Por fim, as estimativas também são controladas pela distância entre a igreja (ADVEC) e o local de votação.

A Tabela 5 informa os resultados dos modelos de mínimos quadrados ordinários 
Tabela 5 - Correlação entre a distância da igreja e o local de votação e o suporte eleitoral ao PT - Eleições presidencias (2018)

\begin{tabular}{lccc}
\hline \hline & $(1)$ & $(2)$ & $(3)$ \\
& PT (2018) & PT (2018) & PT (2018) \\
\hline ADVEC & $-8.568^{* * *}$ & $-7.401^{* * *}$ & $-7.401^{* * *}$ \\
& $(1.391)$ & $(.7208)$ & $(2.641)$ \\
Controles & & & \\
Distância (1-5Km) & $\checkmark$ & & $\checkmark$ \\
Comparecimento & & $\checkmark$ & $\checkmark$ \\
Nível educacional & & $\checkmark$ & \\
\hline & & & \\
Erro padrão robusto & $\checkmark$ & $\checkmark$ & $\checkmark$ \\
Efeito fixo & & $\checkmark$ & $\checkmark$ \\
Erros clusterizados & & & 3,652 \\
\hline Observações & 3,652 & 3,652 & 165 \\
N. clusteres & - & - & \\
\hline \hline
\end{tabular}

Erro padrão entre parênteses.

${ }^{*} p<0.05,{ }^{* *} p<0.01,{ }^{* * *} p<0.001$

Nota: elaborado pelo autor a partir dos dados do Tribunal Superior Eleitoral (TSE) e Google Maps. A unidade de análise é o local de votação $(\mathrm{N}=3,652)$. ADVEC = assume valor 1 se existe uma igreja dessa denominação no mesmo CEP da seção eleitoral, 0 caso contrário. Os modelos de mínimos quadrados ordinários utilizam os seguintes controles: distância entre a igreja e o local de votação, taxa de comparecimento eleitoral (turnout) e a média do nível educacional do local de votação. Erros padrões robustos são utilizados nos modelos 1 e 2. O modelo 2 apresenta correção por efeitos fixos no nível distrito-bairro, enquanto o modelo 3 também inclui erros clusterizados no nível das zonas eleitorais.

estimados. O modelo base (1), que inclui apenas um controle de distância e erro padrão robusto, informa um decréscimo médio de 8 pontos percentuais (pp) na votação do PT nos locais de votação com uma ADVEC próxima (IC de 99\%). Na estimativa com efeitos fixos de distrito-bairro e controlada pela taxa de comparecimento e nível educacional dos eleitores (2), o efeito negativo estimado é cerca de 1 ponto percentual menor (7.4 pp), mas também substantivo e estatisicamente significante (IC de 99\%). O modelo 3 apresenta um erro padrão maior (por efeito da clusterização), mas o efeito substantivo da variável de interesse é virtualmente o mesmo (IC de 99\%). Em suma, os resultados indicam que nas áreas sob influência dos pastores da ADVEC, a votação do PT foi menor nas eleições presidenciais de 2018. 
Esses resultados, contudo, devem ser tomados com cautela. Em primeiro lugar, pode haver variáveis omitidas não consideradas nos modelos apresentados na tabela 5. Infelizmente, os dados censitários do IBGE não possuem uma perfeita correspondência com os códigos identificadores dos locais de votação, o que impede a consideração de outras variáveis de nível local. Em segundo lugar, é possível que essas estimativas sejam superestimadas pela existência de outras igrejas pentecostais no mesmo CEP, mas que não foram levadas em conta em virtude da limitação dos dados utilizados. Ou seja, o efeito observado pode não ser apenas da ADVEC, mas também de eleitores de baixa renda que frequentam outras igrejas pentecostais perto dos locais de votação. Finalmente, mas não menos importante, existe a possibilidade de falácia ecológica inerente ao uso de dados agregados. Portanto, interpreto as correlações apresentadas na tabela 5 como evidências preliminares em favor da hipótese de que os pastores pentecostais (Brokers) exercem influência sobre o voto dos eleitores de baixa renda.

\subsection{Efeito do pastor ou falácia ecológica?}

Para mitigar a suspeita de que as conclusões apresentadas na seção anterior resultam de falácia ecológica, utilizo dados de nível individual para testar a hipótese de que a atuação dos pastores pentecostais influencia o voto dos membros de suas igrejas. Para tanto, analiso o comportamento eleitoral dos membros da Igreja Universal do Reino de Deus (IURD) em duas eleições presidenciais brasileiras (2010 e 2014).

Fundada por Edir Macedo em 1977, a IURD possui seis mil templos, doze mil pastores e quase 2 milhões ${ }^{16}$ de membros espalhados por todo o Brasil, sobretudo nas

16 Este número não inclui os membros que frequentam os templos da IURD em mais de 100 países na América Latina, Europa e África. 
áreas pobres urbanas ${ }^{17}$. Embora tenha sido enquadrada por Freston (1994) naquilo que o autor chamou de terceira fase do pentecostalismo brasileiro (a fase do neopentecostalismo), essa denominação possui características peculiares que a distinguem das igrejas pentecostais clássicas. As principais são a forte orientação para a Teologia da Prosperidade $^{18}$ e menor apelo às questões morais. Por exemplo, seu líder, Edir Macedo, defende abertamente a descriminalização do aborto $^{19}$. Além disso, em 2010, a Igreja declarou publicamente apoio à candidatura da petista Dilma Rousseff ao Palácio do Planalto (SOUZA, 2013).

Figura 21 - Votação do PT nas eleições presidenciais entre os membros da IURD (2010 e 2014)

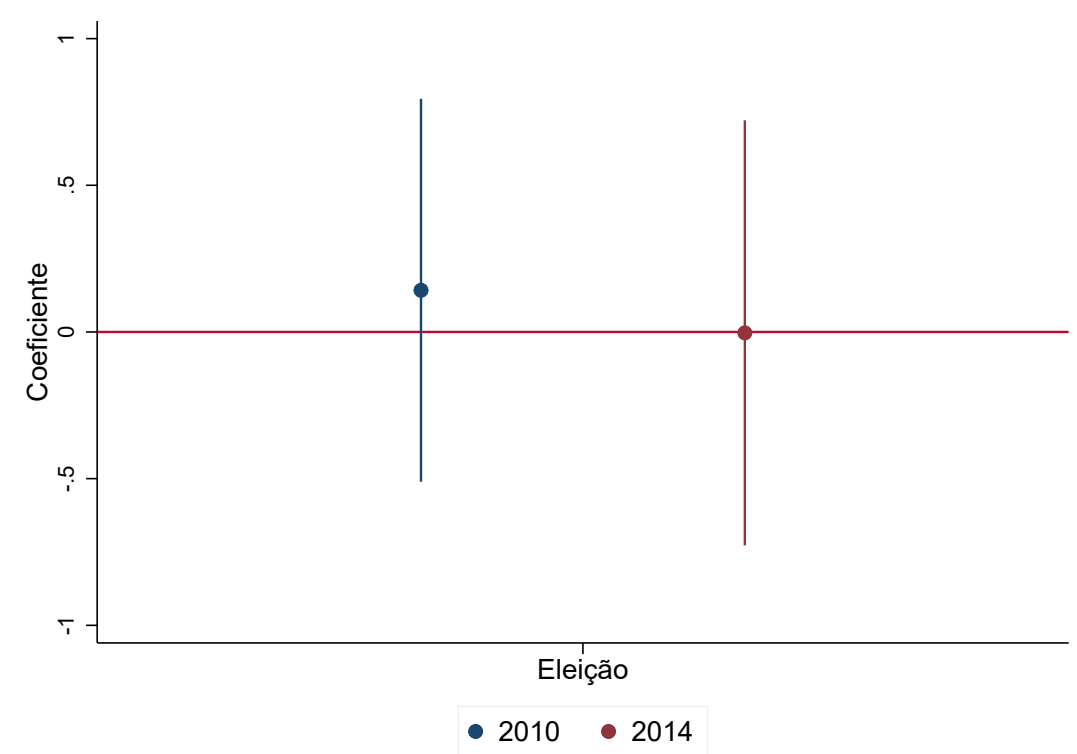

Nota: elaborado pelo autor a partir dos dados do Estudo Eleitoral Brasileiro (ESEB, 2014). A unidade de análise é o indivíduo $(\mathrm{N}=3,049)$. Os modelos de regressão logística foram ajustados com erros padrões robusto, utilizando os seguintes controles: idade, sexo, renda, escolaridade, raça, status ocupacional, percepção da economia, preferência partidária, região, frequência à igreja e uma variável que indica se o indivíduo é um beneficiário do Programa Bolsa Família.

Portanto, não deveríamos observar uma forte rejeição ao PT neste caso, dado

17 Para uma descrição detalhada sobre as igrejas neo-pentecostais no Brasil, em especial a IURD, ver Mariano (1999) e Mariano (2004)

18 Corrente da teologia evangélica que defende que a bênção financeira é o desejo de Deus para os cristãos.

19 O Anexo A reporta o texto publicado por Edir Macedo em Setembro de 2010, um mês antes do primeiro turno das eleições presidenciais, no qual o líder da IURD defende a prática do aborto utilizando uma passagem da Bíblia para fundamentar sua opinião. 
que as propostas mais progressistas do partido não conflitam com os valores morais pregados pelas lideranças da IURD. Os dados do ESEB (2010 e 2014) permitem estimar a probabilidade de um indivíduo filiado à IURD ter votado no PT nas eleições de 2010 e 2014. A figura 21 informa uma estimativa positiva e não estatisticamente significante para 2010 e outra indistinguível de zero nas eleições de 2014. Substantivamente, as estimativas sugerem que os indivíduos que frequentam a IURD são menos propensos a rejeitar o PT nas urnas quando comparados a outras religiões. Resultado que vai ao encontro das evidências qualitativas apresentadas por Barbosa (2016) que sugerem que a renda (e não o conservadorismo moral) pauta a decisão dos eleitores da IURD em eleições presidenciais.

Uma limitação desse tipo de análise cross-section ${ }^{20}$ é que todos os indivíduos são entrevistados em um único ponto do tempo, de modo que os dados do ESEB utilizados nos testes acima não permitem estimar o efeito exógeno do pentecostalismo (ou, mais especificamente, da conversão ao pentecostalismo) sobre a mudança nas preferências dos indivíduos.

Como alternativa, utilizo dados em painel - originalmente coletados e sistematizados por Baker, Ames e Renno (2006) ${ }^{21}$ - para estimar o efeito da conversão ao pentecostalismo sobre a percepção moral dos indivíduos. Para os fins deste trabalho, importa destacar que os mesmos indivíduos foram entrevistados seis vezes, em sucessivas rodadas da pesquisa executadas entre Março de 2002 e Outubro de 2006 nas cidades de Caxias do Sul (RS) e Juiz de Fora (MG). Utilizo uma versão restrita da amostra que abrange as primeiras quatro rodadas (Março de 2002=1, Agosto de 2002=2, Outubro

20 Também conhecido como análises de dados transversal, esse tipo de estudo observacional analisa dados de uma população, ou de um subconjunto representativo, em um ponto específico no tempo.

21 Originalmente, estes dados foram coletados para investigar a volatilidade dos indivíduos em relação às suas preferências partidárias no período entre eleições. 
de 2002=3, e Maio de 2004=4) e que contém um conjunto comparável ${ }^{22}$ de questões (N $=9,087)$. Os indivíduos foram acompanhados no tempo para identificar aqueles que se converteram ao pentecostalsimo entre Abril de 2002 e Maio de 2004. Ao todo, 74 indivíduos da amostra fizeram a transição religiosa nesta direção.

Como sustento neste trabalho, as lideranças pentecostais fazem uso de argumentos morais, amparados por preceitos bíblicos e fundamentados na teologia pentecostal, para mobilizar o eleitorado contra os candidatos de esquerda. A ideia básica contida nesse argumento é que o pentecostalismo altera a percepção moral que os eleitores de baixa renda têm sobre esses candidatos. Para testar essa hipótese de forma mais sistemática, utilizo duas perguntas contidas no questionário da pesquisa referida acima. A primeira afere "O que é mais importante em um candidato a cargo eleitoral? Que ele ou ela seja competente, mesmo que pouco honesto ou que ele ou ela seja honesto, mesmo que pouco competente."A variável assume valor 1 se o indivíduo prefere que o candidato seja honesto, mesmo que incompetente, e 0 caso contrário. A segunda questiona se o entrevistado "acha que o Lula ${ }^{23}$ é muito honesto, honesto, pouco honesto ou nada honesto". Neste caso, a variável assume valor 1 para as respostas "Muito honesto"e "honesto", 0 caso contrário. O questionário também contém características sociodemográficas dos entrevistados, como idade, raça e nível educacional, bem como outros importantes preditores de suas preferências individuais, como status ocupacional, preferência partidária e percepção da economia. Utilizo essas perguntas como variáveis de controle.

As estimativas reportadas na figura 22 (painel A) indicam que os indivíduos

22 Várias questões não foram aplicadas nas rodadas 5 e 6 da pesquisa, por isso optei por não utilizar as informações dessas etapas da pesquisa.

23 Lula foi candidato pelo PT (nas eleições de 2002) e Presidente da República (2003-2006) no período abrangido pela pesquisa. 
Figura 22 - Percepção moral dos indivíduos antes (2002) e depois (2004) da conversão ao pentecostalismo

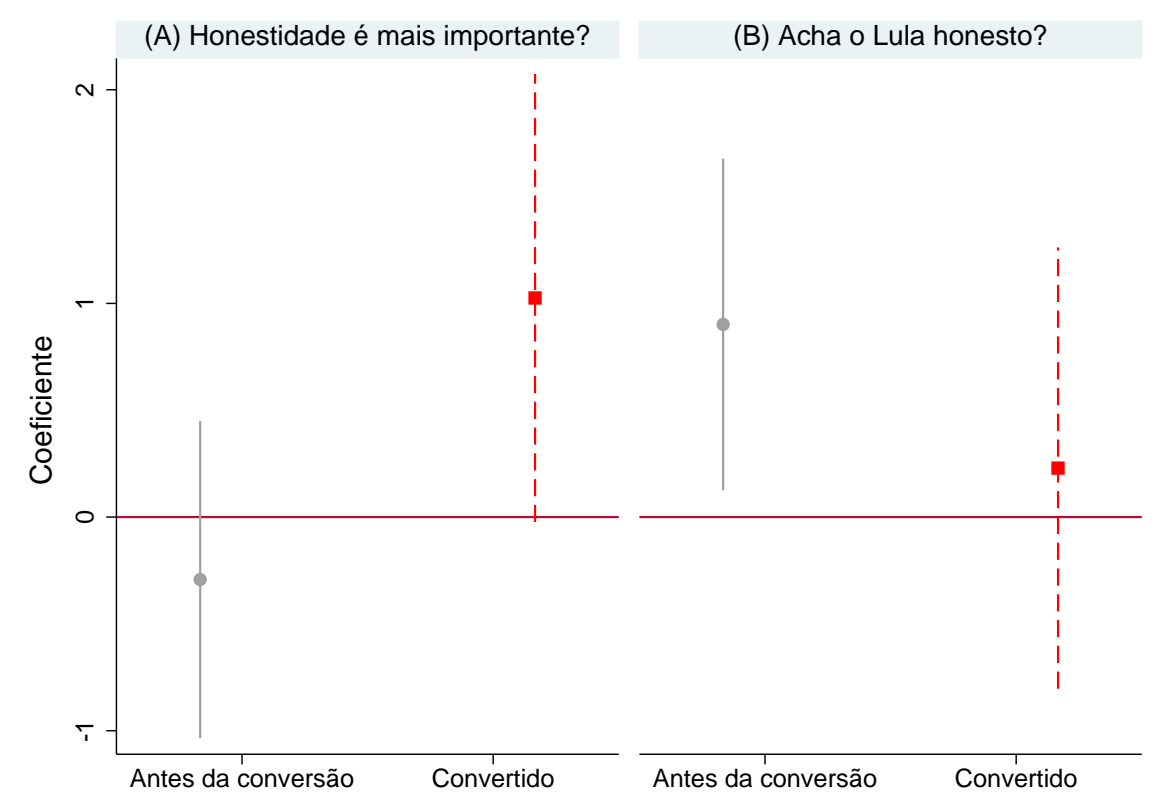

Nota: elaborado pelo autor a partir dos dados da pesquisa Two-City Brazilian Panel Study Dataset (BAKER; AMES; RENNO, 2006). A unidade de análise é o indivíduo. Os modelos de regressão logística foram ajustados com erros padrões robustos, utilizando os seguintes controles: idade, raça, nível educacional, frequência à igreja e percepção da economia, bem como se o indivíduo possui um trabalho fixo, preferência partidária pelo PT ou costuma ler notícias de economia e política em jornais.

valorizam menos a honestidade dos candidatos antes da conversão ao pentecostalismo, como indica o resultado estatisticamente não significante para a categoria "Antes da conversão"reportado no painel A. Antes de se converter, a perspectiva de apoiar um político honesto e incompetente tende a ser rejeitada. Após a conversão, observamos uma mudança na percepção desses mesmos indivíduos. Quando comparados àqueles de outras religiões, a chance de um pentecostal convertido optar pela honestidade em detrimento da competência do candidato é cerca de 3 vezes maior (IC de 95\%).

As estimativas da figura 22 (painel B) sugerem que o pentecostalismo também afeta o modo como os eleitores julgam o caráter dos candidatos de esquerda. Antes da conversão, existia uma clara percepção entre os indivíduos de que o político Lula era honesto (IC de 95\%). Após o conversão, no entanto, o coeficiente se torna não significante 
nos níveis convencionais, o que sugere um substantivo aumento da percepção de desonestidade deste candidato. Vale destacar que as estrevistas da rodada quatro da pesquisa foram conduzidas em Maio de 2004, de modo que, por uma questão temporal, é improvável que esse resultado seja um efeito dos esquemas de corrupção que vieram à tona meses depois ${ }^{24}$. Embora os dados não sejam representativos para todo o Brasil e, portanto, não devam ser extrapolados para outros contextos, a interpretação mais plausível para os resultados reportados neste capítulo é que a mudança na percepção moral dos indivíduos é um efeito da mobilização promovida nas igrejas pentecostais.

24 O esquema do Mensalão foi noticiado pela primeira vez no dia 14 de maio de 2005 pela Revista Veja, praticamente 12 meses depois que a pesquisa foi conduzida. 



\section{Pentecostalismo e políticas públicas}

Democracias tendem a redistribuir mais renda do que governos autoritários (LAKE; BAUM, 2001; STASAVAGE, 2005; MANI; MUKAND, 2007; HARDING; STASAVAGE, 2013). A existência de eleições pressiona os governos a implementarem políticas que espelham as preferências da maioria do eleitorado. Dado que os eleitores podem utilizar as urnas para punir ou retribuir seus governantes, espera-se que os políticos se esforcem para aumentar o bem-estar da porção mais importante do eleitorado aquela com capacidade de decidir as eleições. A presunção é que o eleitor pratica o voto econômico, ou seja, tende a retribuir com a reeleição o candidato responsável por aumentar seu bem-estar (LEWIS-BECK; PALDAM, 2000; BECHTEL; HAINMUELLER, 2011). Neste capítulo, discuto como a identidade religiosa pode perverter essa lógica e afetar o modo como os beneficiários reagem nas urnas às políticas de redistribuição de renda.

\subsection{Bolsa Família e voto econômico}

As eleições presidenciais de 2006 marcaram a recondução do PT à Presidência da República. Mesmo depois da revelação de um vultoso esquema de pagamentos a parlamentares para votar a favor de projetos importantes para o governo - escândalo batizado como "Mensalão" -, o candidato do PT, Luiz Inácio Lula da Silva, foi reeleito no segundo turno com $60,83 \%$ dos votos válidos. O lançamento do Bolsa Família (PBF, 2004), um programa de transferência condicional de renda ${ }^{1}$, é apontado como fator

1 O benefício monetário mensal, destinado às famílias pobres com filhos entre 0 e 17 anos, exige como contrapartida que as famílias beneficiadas enviem seus filhos para a escola e que mantenham a carteira 
determinante para o sucesso eleitoral do PT em 2006. Além de seus impactos sobre o mercado de trabalho local (SOARES; RIBAS; OSÓRIO, 2010), o PBF é associado ao aumento do consumo de alimentos (BRAUW et al., 2015), à redução da pobreza (LUSTIG, 2010) e da mortalidade infantil (RASELLA et al., 2013).

Hunter e Power (2007) argumentam que o efeito desse programa sobre o bemestar dos mais pobres foi fundamental para a reeleição de Lula. De acordo com estes autores, as eleições de 2006 foram marcadas pela expansão do PT entre os eleitores mais pobres e com menor educação formal. Na mesma linha, os trabalhos de Nicolau e Peixoto (2007), Soares e Terron (2008) e Licio, Rennó e Castro (2009) mostram que o PBF foi decisivo no processo de transformação da região Nordeste em reduto petista nas eleições presidenciais a partir de 2006. Canêdo-Pinheiro (2015) vai além ao mostrar que o peso do PBF foi maior do que o crescimento econômico nas eleições de 2006, enquanto Zucco (2015) apresenta evidência de que o efeito eleitoral do programa pôde ser observado ainda nas eleições de 2014, dez anos após o lançamento do programa.

Neste capítulo, ofereço uma explicação alternativa para o crescimento eleitoral do PT nas áreas menos urbanizadas com maior concentração de pobreza. Mostro que o crescimento do PT no Nordeste não se deve à maior concentração de beneficiários nesta região, mas ao fato de haver efeitos eleitorais do programa apenas entre os eleitores católicos, maioria nas regiões menos urbanizadas.

\subsection{Religião como variável interveniente}

Em geral, os trabalhos que analisam os efeitos eleitorais de programas de transferência de renda investigam se os beneficiários tendem a votar mais no partido que de vacinação infantil em dia. 
implementou o programa. Quando o programa é implementado de forma aleatória - i.e. quando é realizado um sorteio para escolher os indivíduos que serão (e os que não serão) beneficiados pelo programa - é possível estimar de maneira razoavelmente simples o efeito eleitoral do programa.

Um exemplo do uso de desenhos experimentais para implementar e avaliar programas de transferência de renda pode ser encontrado no México. O Progresa, posteriormente rebatizado como Oportunidades, foi implementado originalmente em 1997 como um programa-piloto em algumas regiões do país. Dentro dessas regiões, algumas comunidades foram selecionadas para receber o programa em sua primeira fase e outras seriam contempladas em uma segunda fase. Depois da implementação do programa, foi possível comparar os dois grupos de municípios e avaliar os efeitos políticos (DELAO, 2013) e socioeconômicos (FERNALD; GERTLER; NEUFELD, 2008) do programa de transferência de renda.

No Brasil, o caso mais emblemático de transferência condicional de renda é o PBF. Instituído em 2004, o programa foi implementado ao mesmo tempo em todos os municípios brasileiros. Como os municípios variam em suas características, a tarefa de isolar o efeito do programa de outras potenciais variáveis que também podem afetar o comportamento eleitoral dos indivíduos torna-se complexa. Zucco (2013) realizou o exercício mais avançado nessa direção ao comparar apenas os municípios com uma proporção similar de beneficiários quando o programa foi implementado em 2004. No entanto, os resultados apresentados pelo autor não podem ser interpretados como causais em virtude de potenciais variáveis omitidas ${ }^{2}$.

2 O viés de variável omitida é produzido pela não consideração de alguma característica da unidade de análise (e.g. indivíduo, distrito ou município) potencialmente relacionada com a variável de interesse. Em análises não experimentais, quando os grupos controle e tratamento não são balanceados, esse tipo de viés tende a afetar as estimativas. 
Neste capítulo, utilizo metodologia similar àquela adotada por Nicolau e Peixoto (2007) para estimar o efeito do PBF sobre a votação do PT nas eleições presidenciais. Isso significa estimar como a proporção de beneficiários do PBF se relaciona com a proporção de votos válidos do PT em cada município, mantidas outras variáveis constantes ${ }^{3}$. No entanto, introduzo a variável "Religião" como um fator interveniente. Assumo que a interação entre a proporção de beneficiários e a proporção de indivíduos filiados a uma dada religião produz efeitos heterogêneos sobre a votação do PT nas eleições presidenciais. Formalmente, estimo a seguinte equação:

$$
Y_{i j}=X_{i j} \beta+Z_{i j} \beta+w_{i j}+u_{i j}+e_{i j}
$$

Onde $\boldsymbol{Y}_{i j}$ é uma variável contínua que mensura a proporção de votos válidos do PT no município $\boldsymbol{i}$ na eleição $\boldsymbol{j}, \boldsymbol{X}_{\boldsymbol{i}} \boldsymbol{\beta}$ é uma variável de interesse que indica a proporção da população no município $i$ na eleição $j$ beneficiada pelo $\mathrm{PBF}, Z_{i j}$ é uma variável interveniente denominada "Religião" que presumivelmente afeta $\boldsymbol{Y}_{\boldsymbol{i} \boldsymbol{j}}$ através de $\boldsymbol{Z}_{\boldsymbol{i j}} \boldsymbol{\beta}$, $\boldsymbol{w}_{i j}$ é um vetor de covariáveis que expressa características de nível municipal, enquanto $e_{i j}$ denota o uso de erros clusterizados no nível do município.

Apesar de não causal, essa abordagem permite identificar os efeitos heterogêneos derivados das diferentes filiações religiosas dos beneficiários do PBF. O menor conservadorismo moral entre os eleitores católicos tende a reforçar a identidade de renda por meio da qual a lógica do voto econômico opera. Por seu turno, entre os eleitores pentecostais, o maior conservadorismo moral fortalece a identidade religiosa que tende a minar potenciais efeitos eleitorais do PBF. Formalmente, apresento as seguintes hipóteses:

3 Isso significa que o objetivo não é estimar o efeito causal do PBF sobre a votação do PT nas eleições presidenciais. 
- Hipótese de nível agregado (i): mantidos outros fatores constantes, o aumento do gasto com o PBF tende a se converter em mais votos para o PT nas eleições presidenciais nos municípios com maior concentração de católicos;

- Hipótese de nível agregado (ii): mantidos outros fatores constantes, o aumento do gasto com o PBF tende a se converter em mais votos para o PT nas eleições presidenciais nos municípios com maior concentração de evangélicos tradicionais;

- Hipótese de nível agregado (iii): mantidos outros fatores constantes, o aumento do gasto com o PBF não implica ganhos eleitorais para o PT nas eleições presidenciais nos municípios com maior concentração de evangélicos pentecostais;

- Hipótese de nível individual (iv): mantidos outros fatores contantes, o suporte eleitoral ao PT é maior entre os beneficiários do PBF com filiação religiosa católica;

- Hipótese de nível individual (iv): mantidos outros fatores constantes, o suporte eleitoral ao PT é maior entre os beneficiários do PBF com filiação religiosa evangélica tradicional;

- Hipótese de nível individual (vi): mantidos outros fatores constantes, o suporte eleitoral ao PT é menor entre os beneficiários do PBF com filiação religiosa evangélica pentecostal.

A mobilização promovida nas igrejas pentecostais contra os candidatos de esquerda pode subtrair da memória do eleitor de baixa renda os ganhos promovidos pelo programa de transferência de renda. Nos cultos católicos, os beneficários do PBF são menos expostos a mobilizações contrárias aos partidos de esquerda, abrindo caminho para a expressão do voto econômico. A mesma lógica pode ser aplicada aos beneficiários evangélicos tradicionais. 


\subsection{Evidência de nível municipal}

Começo explorando os resultados de nível agregado. Neste caso, investigo se a interação entre as categorias religiosas e a distribuição dos beneficiários do PBF no território brasileiro afeta a proporção de votos do PT nas eleições presidenciais. A figura 23 apresenta as estimativas do efeito do PBF sobre a votação do PT de acordo com as categorias religiosas. Nas eleições de 2006, o aumento da proporção de beneficiários do PBF produziu aumento da proporção de votos válidos do PT nas eleições presidenciais, mas apenas nos municípios com maioria católica. Padrão muito similar pode ser observado nas eleições de 2010, 2014 e 2018. Todas as estimativas para este grupo são significantes ao nível de 95\%.

Como a região Nordeste concentra a maior parte dos indivíduos católicos, uma interpretação possível é que o efeito positivo observado nesse grupo seja, na verdade, um efeito de região. Para mitigar essa suspeita, a figura 23 apresenta as estimativas da categoria "Católicos" sem os municípios da região Nordeste (CATOL (SN)). Como esperado, o coeficiente é sensivelmente menor, mas o resultado se mantém positivo e estatiscamente significante (IC de 95\%). Na média, o aumento da proporção de beneficiários do PBF produz aumento de votos para o PT quando combinado ao aumento da população católica nos municípios.

Os resultados para a categoria "evangélicos tradicionais" são mistos. A estimativa positiva e não significante nas eleições de 2006 contrasta com estimativas negativas e significantes nas eleições de 2010 e 2014. Em 2018, o efeito do PBF sobre os votos do PT pode ser considerado zero para este grupo. Em geral, esses resultados acompanham as evidências do capítulo 2, que sugerem um comportamento eleitoral menos consistente 
dos eleitores evangélicos tradicionais.

Figura 23 - Efeito do PBF sobre a votação do PT por filiação religiosa - nível municipal (2006-2018)
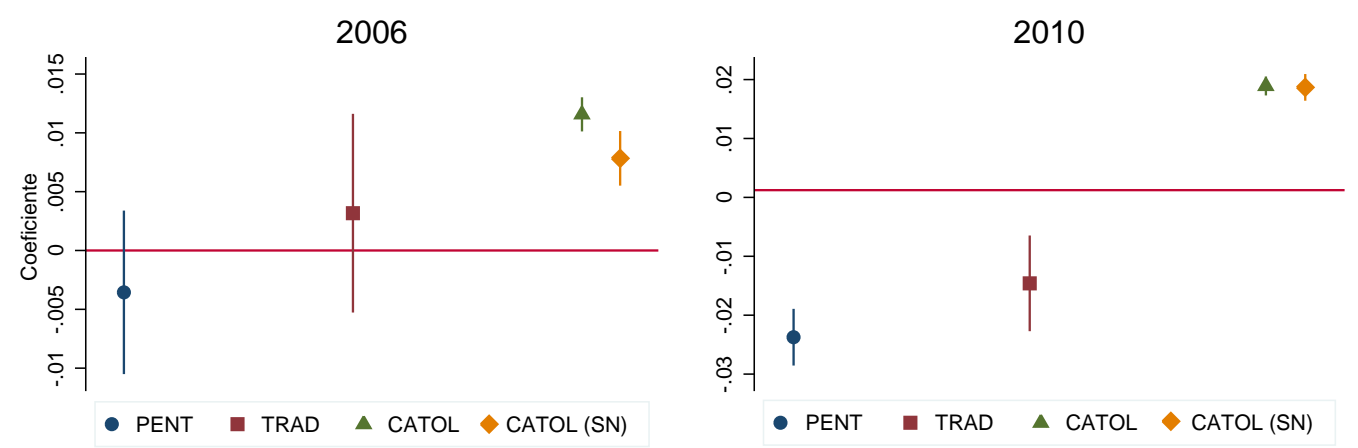

2014
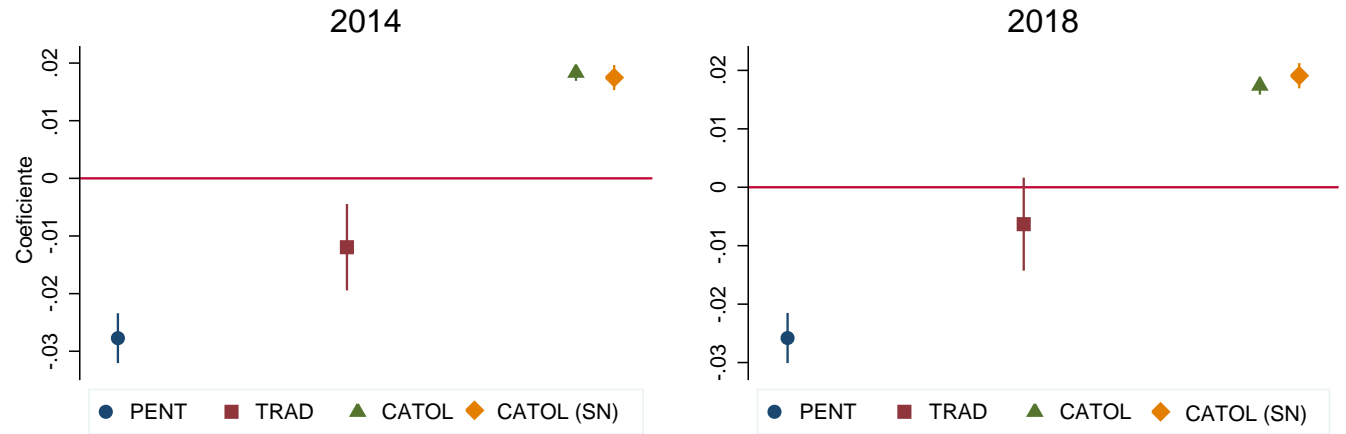

Nota: elaborado pelo autor a partir dos dados do Estudo do Instituto Brasileiro de Geografia e Estatística (IBGE) e do Tribunal Superior Eleitoral (TSE). A unidade de análise é o município $(\mathrm{N}=5,565)$. Os modelos de mínimos quadrados ordinários apresentados na figura 23 foram ajustados com erros clusterizados no nível do município. As seguintes covariáveis foram utilizadas: taxa de analfabetismo, taxa de pobreza, renda per capita, índice de desigualdade medido pelo coeficiente de Gini, índice de desenvolvimento humano (IDH) e uma variável que informa a região de cada município.

No outro extremo, a figura 23 indica que a implementação do PBF não se traduziu em aumento do suporte eleitoral ao PT nos municípios com maioria evangélica pentecostal. Nas eleições de 2006, na média, a votação do PT não cresceu no grupo dos evangélicos pentecostais. Além disso, as estimativas para 2010, 2014 e 2018 são negativas e estatisticamente significantes (IC de 95\%), o que sugere que os beneficiários desse grupo tendem a não retribuir o PT com votos nas eleições presidenciais. 


\subsection{Evidência de nível individual}

Nesta seção, utilizo dados de nível individual para dirimir o temor de falácia ecológica na interpretação dos resultados agregados por município apresentados na seção anterior. A partir dos dados do ESEB referentes às eleições presidenciais de 2010 e $2014^{4}$, estimo a probabilidade de um beneficiário do PBF votar no PT dada a sua filiação religiosa. Formalmente, estimo a seguinte equação:

$$
Y_{i t}=X_{i t} \beta+Z_{i t} \beta+w_{i t}+u_{i t}+e_{i t}
$$

Onde $\boldsymbol{Y}_{i t}$ é uma variável binária que indica se o indivíduo $\boldsymbol{i}$ votou no PT na eleição $j, \boldsymbol{X}_{i t} \boldsymbol{\beta}$ é uma variável binária que indica se o indivíduo $\boldsymbol{i}$ era beneficiário do PBF na eleição $j, Z_{i t}$ é uma variável interveniente denominada "Religião" que presumivelmente afeta $\boldsymbol{Y}_{i t}$ através de $\boldsymbol{Z}_{i t} \boldsymbol{\beta}$, enquanto $\boldsymbol{w}_{i t}$ é um vetor de covariáveis com características de nível individual.

As evidências de nível individual confirmam os resultados agregados por município. Em geral, ser beneficiário do PBF aumenta as chances de o indivíduo votar no PT, mas os resultados são substantivos e estatiscamente significantes (IC de 95\%) apenas para os beneficiários com filiação católica. As chances de um indivíduo com essa combinação de características votar no PT foi 64\% maior em 2010 e 77\% maior em 2014. A figura 24 também mostra que este resultado se mantém mesmo excluíndo os indivíduos do Nordeste da amostra (CATOL (SN)), sugerindo que não se trata de um efeito de região, mas sim um efeito heterogêneo da filiação religiosa dos indivíduos.

4 Neste caso, existe um motivo adicional para focar apenas nas eleições de 2010 e 2014: o questionário de 2006 não pergunta aos entrevistados se estes são beneficiários do PBF. 
Figura 24 - Efeito do PBF sobre a votação do PT por filiação religiosa - nível individual (2010-2014)
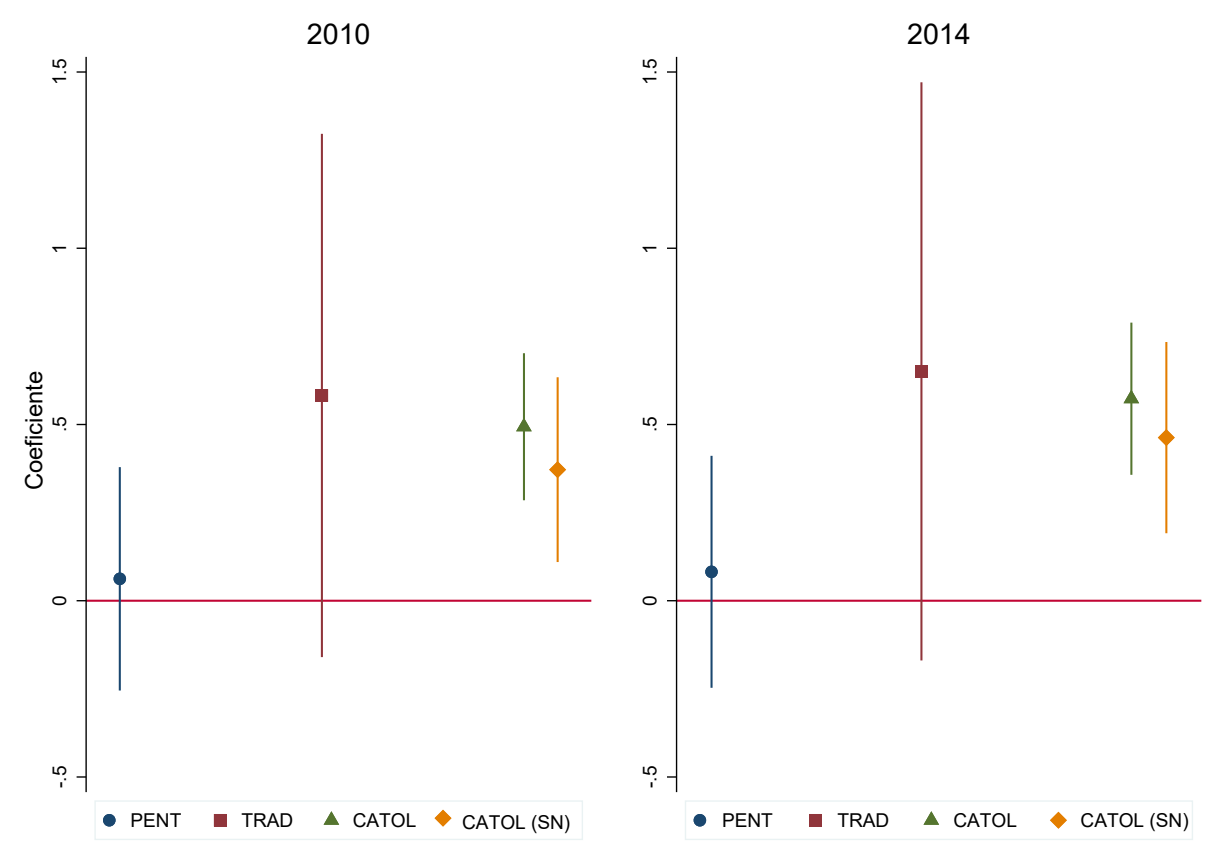

Nota: elaborado pelo autor a partir dos dados do Estudo Eleitoral Brasileiro (ESEB, 2014). A unidade de análise é o indivíduo $(\mathrm{N}=3,049)$. Os modelos de regressão logística apresentados na figura 24 foram ajustados com erros padrões robustos utilizando os seguintes controles: idade, sexo, renda, escolaridade, raça, status ocupacional, percepção da economia, preferência partidária, frequência à igreja e região de moradia do indivíduo.

\subsection{Mecanismos alternativos}

Dado que os católicos se concentram no Nordeste e que essa região também abriga a maior proporção de beneficiários do PBF, o efeito eleitoral do programa nos municípios com maioria católica poderia ser explicado pela maior concentração de beneficiários nesse grupo religioso. Os dados, no entanto, não corroboram essa suposição. A figura 25 reporta a probabilidade de um indivíduo receber o Bolsa Família conforme sua filiação religiosa (A). Não existe diferença estatisticamente significante entre os grupos religiosos, resultado esperado uma vez que o critério de alocação do programa é fundamentalmente a renda per capita familiar, independentemente da 
religião professada pelos seus integrantes ${ }^{5}$.

Figura 25 - Acesso aos programas sociais por filiação religiosa (2010)

(A) Bolsa Família

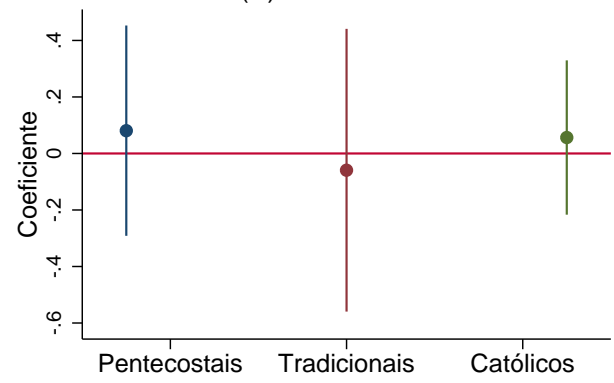

(C) Minha Casa, Minha Vida

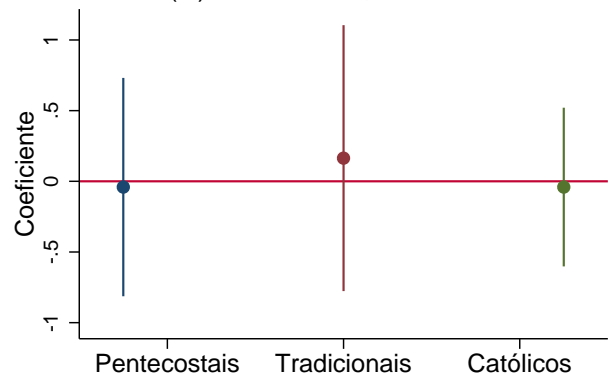

(B) Luz para Todos

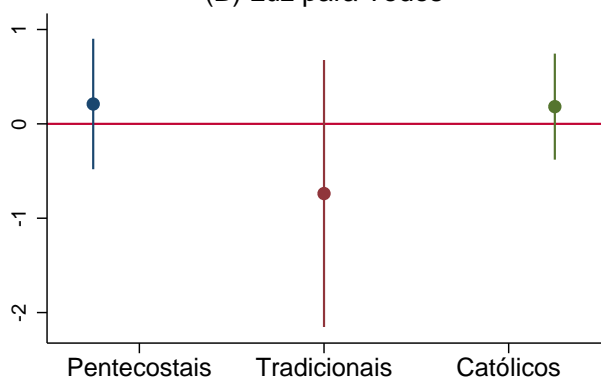

(D) Prouni

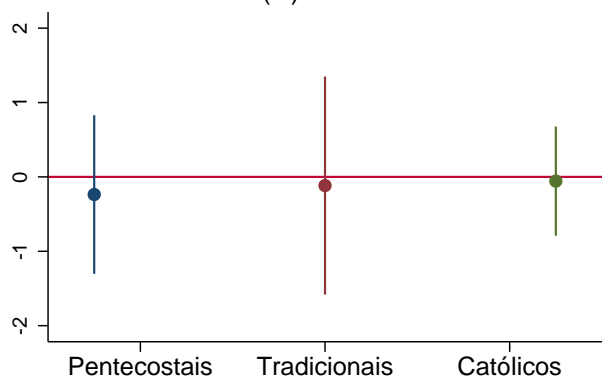

Nota: elaborado pelo autor a partir dos dados do Estudo Eleitoral Brasileiro (ESEB, 2010). A unidade de análise é o indivíduo $(\mathrm{N}=1,691)$. Os modelos de regressão logística apresentados na figura 25 foram ajustados com erros padrões robustos, utilizando os seguintes controles: idade, sexo, renda, escolaridade, raça e região de moradia do indivíduo.

\section{O programa Luz para Todos, criado para levar energia elétrica aos domicílios}

pobres em áreas rurais, e o programa Minha Casa, Minha Vida, criado para reduzir

o défict de moradia em áreas urbanas, são exemplos dos vários programas sociais implementados pelos governos petistas entre 2003 e $2018^{6}$. Se os católicos tendem a acumular tais programas mais do que indivíduos com outras filiações religiosas, os

5 Para acessar o PBF, é preciso ter renda por pessoa de até R \$ 85,00 mensais. Se a família tiver na sua composição crianças ou adolescentes de até 17 anos, o patamar passa para R \$ 170 mensais. A seleção é feita por meio de um sistema informatizado, ou seja, embora seja pré-requisito para ingressar no programa, estar no Cadastro Único não garante a entrada imediata no Bolsa Família. A inscrição no Cadastro Único deve ser feita por uma pessoa da família, chamada de Responsável Familiar, no setor do cadastro ou do Bolsa Família no município. Essa pessoa deve ter pelo menos 16 anos e, preferencialmente, ser mulher. Para fazer o cadastro, é necessário apresentar CPF ou título de eleitor, além de algum documento dos outros integrantes da família. O Responsável Familiar é quem garante que as informações comunicadas durante a entrevista são verdadeiras. Todas as informações devem ser prestadas corretamente, sobretudo a renda e a composição familiar.

6 Para uma revisão das políticas sociais implementados no Brasil entre 1995 e 2014, ver Arretche, Marques e Faria (2019). 
resultados da seção anterior podem ser explicados pela superposição de benefícios sociais entre os eleitores católicos. As estimativas reportadas na figura 25 também refutam essa hipótese. Mantidas outras características constantes, a probabilidade de um indivíduo católico ser beneficiário dos programas Luz para Todos (B), Minha Casa, Minha Vida (C) ou Prouni (D) não é maior quando comparado aos indivíduos de outras religiões.

É possível, ainda, que o PBF tenha possibilitado aumento do bem-estar, medido pela renda, apenas para os beneficiários católicos. Isso justificaria o fato de os beneficiários evangélicos pentecostais não retribuirem o PT nas urnas. Para testar essa hipótese, também utilizo modelos interativos. Formalmente, estimo o efeito interativo da multiplicação de $\boldsymbol{X}_{i j} \boldsymbol{\beta}$, que informa o status de benefiário do indivíduo $\boldsymbol{i}$, e uma variável interveniente $Z_{i j}$, que denota a filiação religiosa do mesmo indivíduo $i$. Neste caso, $\boldsymbol{Y}_{i j}$ é uma variável binária que indica se o indivíduo $i$ avalia que sua situação econômica está melhor do que há doze meses.

Na comparação com as outras religiões, o beneficiário católico é aquele com menor probabilidade de relatar melhoria de sua condição econômica. A figura 26 informa uma estimativa negativa e não estatiscamente significante para esse grupo (IC de 95\%). Os resultados também não indicam uma percepção de melhora entre os beneficiários evangélicos tradicionais. Embora positiva, a estimativa para esse grupo é estatiscamente não significante (IC de 95\%).

Paradoxalmente, a estimativa referente ao grupo dos evangélicos pentecostais é positiva e estatiscamente significante (IC de 90\%). O que significa, de acordo com a lógica do voto econômico, que estes indivíduos deveriam premiar o PT nas urnas como resultado da percepção de melhora de suas condições econômicas. No entanto, 
a identidade religiosa parece ser dominante para essa porção do eleitorado. À luz do argumento proposto neste trabalho, interpreto o baixo desempenho do PT entre esses beneficiários do PBF como um resultado do processo de mobilização contra os candidatos de esquerda promovido nas igrejas pentecostais.

Figura 26 - Avaliação da situação econômica por filiação religiosa (2010)

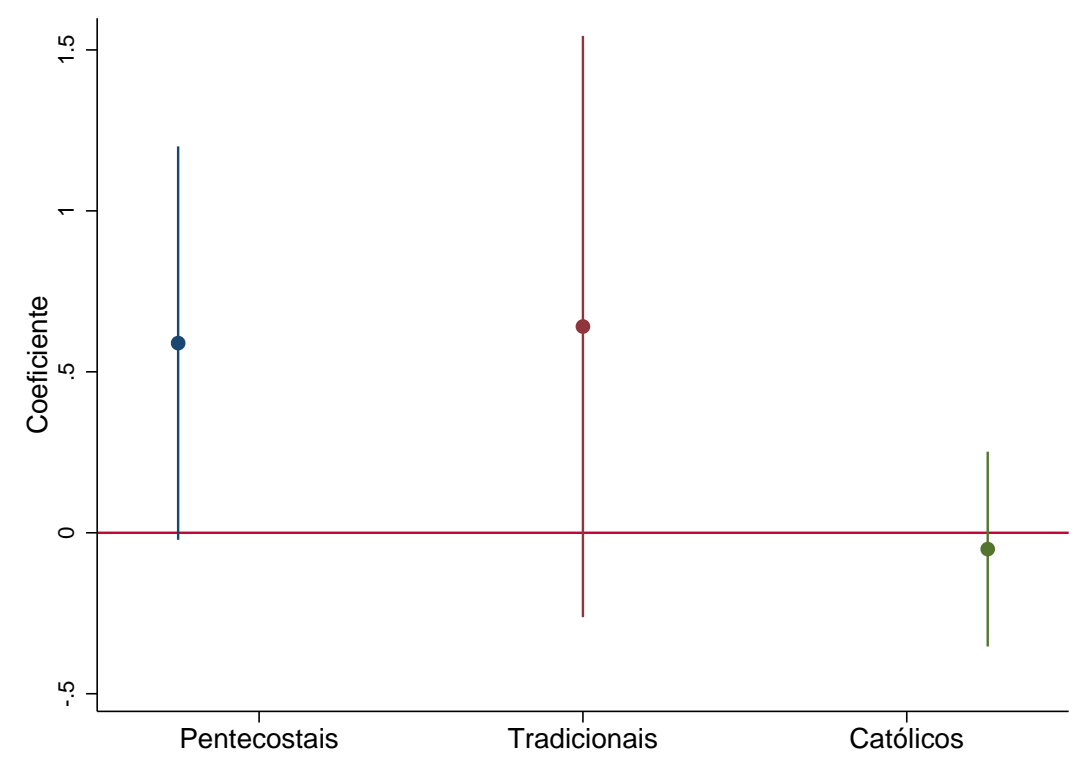

Nota: elaborado pelo autor a partir dos dados do Estudo Eleitoral Brasileiro (ESEB, 2010). A unidade de análise é o indivíduo $(\mathrm{N}=1,691)$. Os modelos de regressão logística apresentados na figura 26 foram ajustados com erros padrões robustos, utilizando os seguintes controles: idade, sexo, renda, escolaridade, raça, percepção da economia do país e região de moradia do indivíduo.

As evidências desta seção parecem confirmar a hipótese de que a identidade religiosa distorce os efeitos eleitorais das políticas de redistribuição. Os resultados parecem indicar três tipos de beneficiários do PBF. Um primeiro, de filiação católica, tende a votar no PT nas eleições presidenciais. Um segundo, evangélico tradicional inconsistente em suas preferências eleitorais, mas que também tende a votar no PT. E um terceiro ligado às igrejas evangélicas pentecostais, que tende a não votar no PT mesmo tendo experimentando aumento do seu bem-estar por intermédio do PBF. 


\subsection{O Brasil em perspectiva comparada}

O pentecostalismo não é um fenômeno cirscunstrito ao caso brasileiro. Estimativas do Pew Research Center para os 18 países da América Latina indicam que dois terços (65\%) dos evangélicos da região se identificam como pentecostais ${ }^{7}$. Seriam os resultados observados na seção anterior restritos ao caso brasileiro ou o pentecostalismo é capaz de minar o efeito eleitoral de políticas redistributivas também em outros contextos na América Latina? Enquanto está fora do escopo deste trabalho uma análise exaustiva dos efeitos da transição religiosa sobre as eleições nas democracias latino-americanas, neste capítulo proponho uma extensão da análise empreendida no capítulo 5 ao caso chileno, país onde o pentecostalismo também é uma corrente expressiva entre os indivíduos de filiação evangélica.

Os dois casos possuem similaridades importantes. Os dois países vêm experimentando uma transição religiosa pelo menos desde 1950. Em 2014, a proporção de católicos era virtualmente a mesma nos dois países: 61\% no Brasil e 64\% no Chile. Em ambos os casos, houve ruptura do acordo democrático que culminou em ditaduras militares que se arrastaram por mais de 20 anos. Além disso, os dois países adotam dois turnos nas eleições presidenciais, expondo os eleitores de baixa renda aos mesmos constrangimentos institucionais no momento de votar ${ }^{8}$. Por fim, os eleitores evangélicos chilenos também tendem a se opor às candidaturas declaradamente à esquerda do

7 Pew Research Center. Religion in Latin America. Disponível em: https://www.pewresearch.org/wpcontent/uploads/sites/7/2014/11/Religion-in-Latin-America-11-12-PM-full-PDF.pdf. Acesso em: 15 mai. 2019.

8 Em sistemas eleitorais com eleições em dois turnos, o eleitor tem incentivos para votar no seu candidato favorito no primeiro turno. Caso esse candidato não dispute o segundo turno, o eleitor tende a votar no candidato que rejeita menos. Esse movimento estratégico do eleitorado em eleições de dois turnos foi postulado por Duverger (1959). Para um teste empírico da "Lei de Duverger" ver Fujiwara et al. (2011). No caso chileno, são realizadas primárias para decidir quais as coligações eleitorais (coalizões) disputarão as eleições, de modo que os eleitores não votam nos partidos diretamente, mas em coalizões que reunem partidos em torno de uma agenda eleitoral. De todo modo, o efeito psicológio postulado por Duverger também tende a ser observado em eleições presidenciais no Chile (SIAVELIS, 2005). 
espectro ideológico (BOAS, 2016).

\subsection{Transferência condicional de renda: Chile solidario}

Em 2000, o então candidato do Partido Socialista do Chile (PS), Ricardo Lagos, foi eleito Presidente da República com 51,3\% dos votos. Diante de uma elevada taxa de desemprego e alto índice de pobreza, o governo Lagos adotou quatro importantes medidas na área de proteção social. Primeiramente, foi instituído um programa de seguro-desemprego para fortalecer o sistema de seguridade dos cidadãos vinculados ao mercado de trabalho formal. Segundo, foi criado um programa de erradicação de favelas, o Chile Barrio, com o objetivo de urbanizar locais com pouco acesso à água tratada e saneamento básico. Terceiro, institui-se a chamada Jornada Escolar Completa, que tornou constitucional e obrigatório pelo menos doze anos de alfabetização para crianças. Quarto, seguindo os moldes do programa Progressa no México, o governo chileno implementou o Chile Solidario (CS), uma política de transferência condicional de renda destinada às famílias extremamente pobres (FOXLEY; ANINAT; ARELLANO, 2013).

O CS foi oficialmente lançado em 2002 e mantido até $2017^{9}$. Assim como no caso do PBF discutido na seção anterior, a transferência de renda foi condicionada à frequência escolar e aos cuidados médicos das crianças das famílias de baixa renda beneficiadas pelo programa. Entre 2002 e 2017, cerca de $8 \%$ da população chilena foi diretamente beneficiados pelo $\mathrm{CS}^{10}$. No mesmo período, o governo chileno investiu

9 Neste ano, o CS foi substituido por outro programa social chamado Segurança e Oportunidades. Os já beneficiários do CS foram integrados ao novo programa e puderam permanecer até atingirem o limite máximo de permanência estipulado pelo governo.

10 Cash transfers in Latin America. Disponível em: https:/ /www.wider.unu.edu/sites/default/files/wp2016136.pdf. Acesso em: 15 jun. 2019. 
0.10\% do Produto Interno Bruto (PIB) nesse programa, em média (AMARANTE; BRUN, 2018). A implementação do CS é associada à criação de empregos e aumento da renda familiar (SCARLATO; D'AGOSTINO; CAPPARUCCI, 2016), efeitos de longo prazo sobre o bem-estar das famílias beneficiadas (MARTORANO; SANFILIPPO, 2012) e efeitos de curto prazo sobre a saúde e educação de crianças nas famílias beneficiadas (GALASSO, 2011).

\subsection{Hipóteses}

Em 1910, 96\% da população chilena se declarava católica. Em 1950, essa proporção havia declinado para $89 \%$. As décadas seguintes foram marcadas por um contínuo declínio até o menor patamar, observado em 2014, quando cerca de 64\% dos chilenos se consideravam católicos ${ }^{11}$. Embora parte desse movimento de desidratação do grupo católico seja explicado pelo aumento daqueles que se declaram sem religião, parte expressiva dos anteriormente adeptos do catolicismo passou a frequentar igrejas evangélicas pentecostais (FRESTON, 2010). O crescimento do pentecostalismo no Chile está fortemente associado ao aumento da pobreza e da vulnerabilidade social (CLEARY; SEPÚLVEDA, 2018), razão pela qual os indivíduos de baixa renda são maioria dentro desse grupo evangélico.

Assumo que o forte conservadorismo moral ensejado pelo pentecostalismo deveria também afetar o comportamento eleitoral dos beneficiários do CS, minando os efeitos eleitorais da redistribuição de renda promovida pelo programa. Assim como no caso brasileiro, o objetivo não é estimar o efeito causal do CS sobre o comportamento

11 Pew Research Center. Religion in Latin America. Disponível em: https:/ /www.pewresearch.org/wpcontent/uploads/sites/7/2014/11/Religion-in-Latin-America-11-12-PM-full-PDF.pdf. Acesso em: 15 mai. 2019. 
eleitoral dos beneficiários do programa, mas analisar as heterogeneidades derivadas da interação do status de beneficiário do indivíduo com sua filiação religiosa.

Sob uma perspectiva estritamente econômica, os beneficiários do programa deveriam premiar nas urnas o partido responsável pela política de transferência de renda. No entanto, a prevalência da identidade religiosa dos indivíduos pode alterar os incentivos eleitorais dos beneficiários que experimentam aumento do bem-estar. Formalmente, hipotetizo que:

- (i) mantidos outros fatores constantes, o suporte eleitoral ao PS é maior entre os beneficiários do CS com filiação religiosa católica;

- (ii) mantidos outros fatores constantes, o suporte eleitoral ao PS é maior entre os beneficiários do CS com filiação religiosa evangélica tradicional;

- (iii) mantidos outros fatores constantes, o suporte eleitoral ao PS é menor entre os beneficiários do CS com filiação religiosa evangélica pentecostal.

\subsection{Políticas redistributivas e voto no Chile}

Nesta seção, utilizo dados de nível individual para testar as hipóteses formuladas acima. A partir dos dados do Latin American Public Opinion Project (LAPOP, 2014), estimo a probabilidade de um beneficiário do CS votar no PS dada a sua filiação religiosa. Formalmente, estimo a seguinte equação:

$$
Y_{i}=X_{i} \beta+Z_{i} \beta+w_{i}+u_{i}+e_{i}
$$


Onde $\boldsymbol{Y}_{\boldsymbol{i}}$ é uma variável binária que indica se o indivíduo $\boldsymbol{i}$ votou no PS na eleição $\boldsymbol{j}, \boldsymbol{X}_{\boldsymbol{i}} \boldsymbol{\beta}$ é uma variável binária que indica se o indivíduo $\boldsymbol{i}$ era beneficiário do CS em 2014, $Z_{i}$ é uma variável interveniente denominada "Religião" que presumivelmente afeta $\boldsymbol{Y}_{\boldsymbol{i}}$ através de $\boldsymbol{Z}_{\boldsymbol{i}} \boldsymbol{\beta}$, enquanto $\boldsymbol{w}_{\boldsymbol{i}}$ é um vetor de covariáveis com características de nível individual.

Devido a limitações de dados ${ }^{12}$, concentro-me na análise das eleições presidenciais de 2014. Substantivamente, a equação 5.1 estima a probabilidade de um beneficiário do CS ter votado na então candidata do PS, Michelle Bachelet, nas eleições de 2014. Embora o programa de transferência de renda tenha sido lançado por Ricardo Lagos, Bachelet foi candidata pelo mesmo partido e contou com o apoio público e explícito de Lagos durante a companha eleitoral em 2013. Assumo, portanto, que os eleitores foram capazes de relacionar a candidatura de Bachelet à primeira fase de implementação do CS durante o governo Lagos.

A figura 27 reporta as estimativas do efeito do CS sobre a votação da candidata Michelle Bachelet de acordo com a filiação religiosa dos indivíduos. Na média, a probabilidade de um beneficiário do CS com filiação evangélica tradicional votar na candidata do PS foi cerca de 70\% maior em 2014 (IC de 95\%). A estimativa para os beneficiários católicos também é positiva, embora não seja estatisticamente significante nos níveis convencionais. De todo modo, o efeito próximo de zero indica menor rejeição à candidatura de Bachelet entre os beneficiários católicos quando comparados aos beneficiários de outras religiões. Como esperado, a estimativa para o grupo dos beneficiários

12 As versões anteriores do LAPOP de 2006, 2008, 2010 e 2012 não permitem estimar a equação 5.1 adequadamente. Em 2006, a pergunta sobre religião não distingue entre evangélicos tradicionais e pentecostais. Em 2008, os entrevistados não foram indagados sobre sua condição de beneficiário do CS. Em 2010, apenas uma pergunta foi feita para saber se o entrevistado era beneficiário de três diferentes programas (Chile Solidario, PASIS, Chile Crece Contigo), de modo que não é possível captar o efeito independente do CS. Em 2012, a pergunta sobre o CS foi feita apenas aos entrevistados dos questionários pares, limitando drasticamente o número de respostas. 
Figura 27 - Efeito do CS sobre a votação do PS por filiação religiosa (2014)

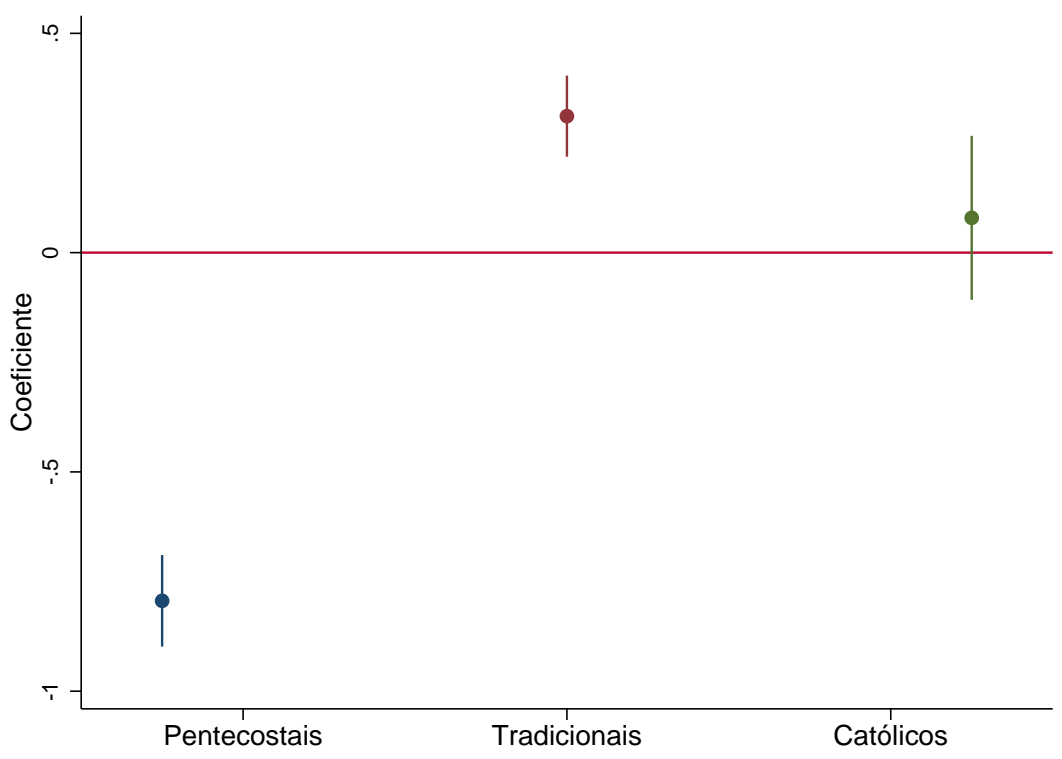

Nota: Latin American Public Opinion Project (LAPOP, 2014). A unidade de análise é o indivíduo (N = 1,571). Os modelos de regressão logística apresentados na figura 27 foram ajustados com erros padrões robustos, utilizando os seguintes controles: idade, sexo, renda, escolaridade, raça, status ocupacional, percepção da economia, preferência partidária, nível de religiosidade, preferência por redistribuição, preferência por taxação, percepção da desigualdade de renda e local de moradia (urbano ou rural) do indivíduo.

evangélicos pentecostais é negativa e estatisticamente significante (IC de 99\%). O que, neste caso, significa uma chance 3.5 vezes menor de os beneficiários pentecostais terem votado na candidata de esquerda nas eleições presidenciais de 2014.

No Chile, chama a atenção o fato de beneficiários católicos terem votado na candidata à esquerda com menor probabilidade do que beneficiários evangélicos tradicionais. Trabalhos futuros poderão investigar esse padrão de forma mais sistemática comparando diversas eleições, algo não realizado neste trabalho por limitações dos dados existentes. De todo modo, os resultados para o caso chileno apontam na mesma direção dos resultados sobre o Brasil. Na média, os evangélicos pentecostais rejeitam os candidatos de esquerda mesmo quando são beneficiados por políticas que atenuam sua condição de pobreza. Em outra direção, beneficiários evangélicos tradicionais e católicos tendem a premiar esses partidos pelo aumento do bem-estar promovido pelas 
políticas de transferência de renda.

\subsection{Mecanismo: o conservadorismo moral pentecostal}

A validade dos resultados apresentados na seção anterior depende da demonstração empírica de que os indivíduos com filiação evangélica pentecostal são mais conservadores na dimensão moral. Idealmente, deveríamos replicar para o caso chileno as análises empreendidas para o caso brasileiro e apresentadas no capítulo 1 . No entanto, o questionário do LAPOP (2014) utiliza outras perguntas para medir o conservadorismo individual. Por exemplo, os entrevistados não foram perguntados sobre a descriminalização da maconha nem sobre a união de casais homoafetivos ${ }^{13}$.

Alternativamente, utilizo uma pergunta sobre o aborto. Em 2014, a pesquisa do LAPOP fez a seguinte pergunta aos entrevistados ${ }^{14}$ : você acredita que a interrupção da gravidez, ou seja, um aborto, justifica-se nos casos em que a saúde da mãe está em risco? Pelo seu caráter extremo, essa pergunta permite observar eventuais heterogeneidades no conservadorismo moral inter-religioso. Substantivamente, estimo a probabilidade de um indivíduo concordar com a realização do aborto em casos de risco de morte da mãe. Formalmente, estimo a seguinte equação:

$$
Y_{i}=X_{i} \beta+w_{i t}+u_{i}+e_{i}
$$

Onde $\boldsymbol{Y}_{i t}$ é uma variável binária que indica se o indivíduo $\boldsymbol{i}$ é favorável ao aborto,

13 No questionário aplicado no Chile, os indivíduos foram perguntados sobre a presença de homossexuais em cargos públicos, o que não permite captar de maneira satisfatória o conservadorismo moral pentecostal porque, neste caso, o comportamento homossexual não se traduz em "ameaça" concreta aos valores da família cristã, como no caso do casamento entre indivíduos do mesmo sexo. A pergunta original em espanhol é a seguinte: ¿Con qué firmeza aprueba o desaprueba que estas personas puedan postularse para cargos públicos?

14 A pergunta original em espanhol é a seguinte: ¿Cree usted que se justificaría la interrupción del embarazo, o sea, un aborto, cuando peligra la salud de la madre? 
$\boldsymbol{X}_{i t} \boldsymbol{\beta}$ é uma variável binária que indica a religião do indivíduo $\boldsymbol{i}, \boldsymbol{w}_{i t}$ é um vetor de covariáveis com características de nível individual, enquanto $e_{i}$ é o termo de erro. As estimativas por filiação religiosa são reportadas na figura 28.

Figura 28 - Opinião sobre o aborto em situações extremas por filiação religiosa (2014)

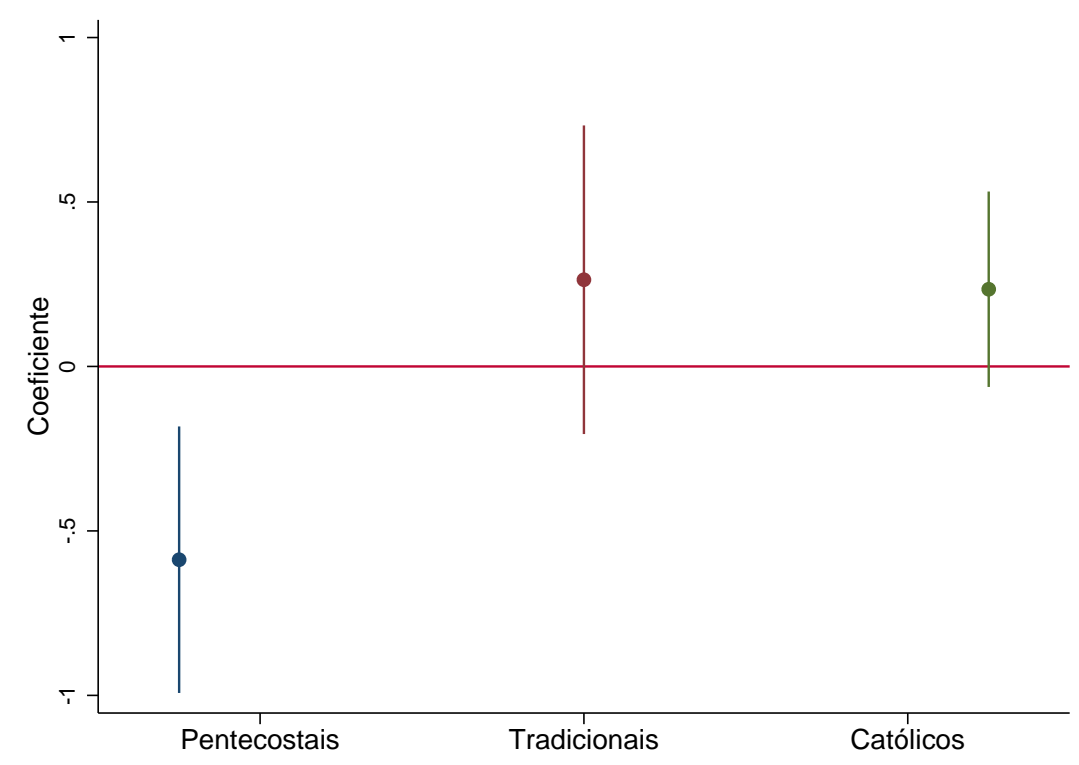

Nota: Elaborado a partir dos dados do Latin American Public Opinion Project (LAPOP, 2014). A unidade de análise é o indivíduo $(\mathrm{N}=1,571)$. Os modelos de regressão logística apresentados na figura 28 foram ajustados com erros padrões robustos, utilizando os seguintes controles: idade, sexo, renda, escolaridade, raça, nível de religiosidade e local de moradia (urbano ou rural) do indivíduo.

Mantidos outros fatores constantes, a probabilidade de um indivíduo com filiação religiosa evangélica pentecostal concordar com um aborto em circunstâncias extremas, como o risco de morte da gestante é $44 \%$ menor (IC de 95\%). Por sua vez, os indivíduos católicos e de filiação evangélica tradicional tendem a apoiar a interrupção da gravidez em situações de risco da gestante, embora as estimativas não sejam estatiscamente significantes (IC de 95\%). Os resultados sugerem, portanto, que o conservadorismo moral observado entre os evangélicos pentecostais é substantiva e estatisticamente maior do que aquele observado nos demais grupos religiosos. 


\subsection{Mecanismos alternativos}

Nesta seção, testo possíveis mecanismos alternativos. O primeiro deles é que a menor predisposição dos beneficiários pentecostais em votar nos partidos de esquerda é simplesmente um reflexo da preferência redistributiva dos indivíduos desse grupo. Para testar essa hipótese, estimo novamente a equação 5.1, mas, neste caso, $\boldsymbol{Y}_{\boldsymbol{i}}$ é uma variável binária que assume valor 1 se o indivíduo concorda com a proposição de que o governo deve implementar políticas firmes para reduzir a desigualdade de renda entre pobres e ricos, e 0 caso contrário ${ }^{15}$.

Figura 29 - Preferência por redistribuição dos beneficiários do CS por filiação religiosa (2014)

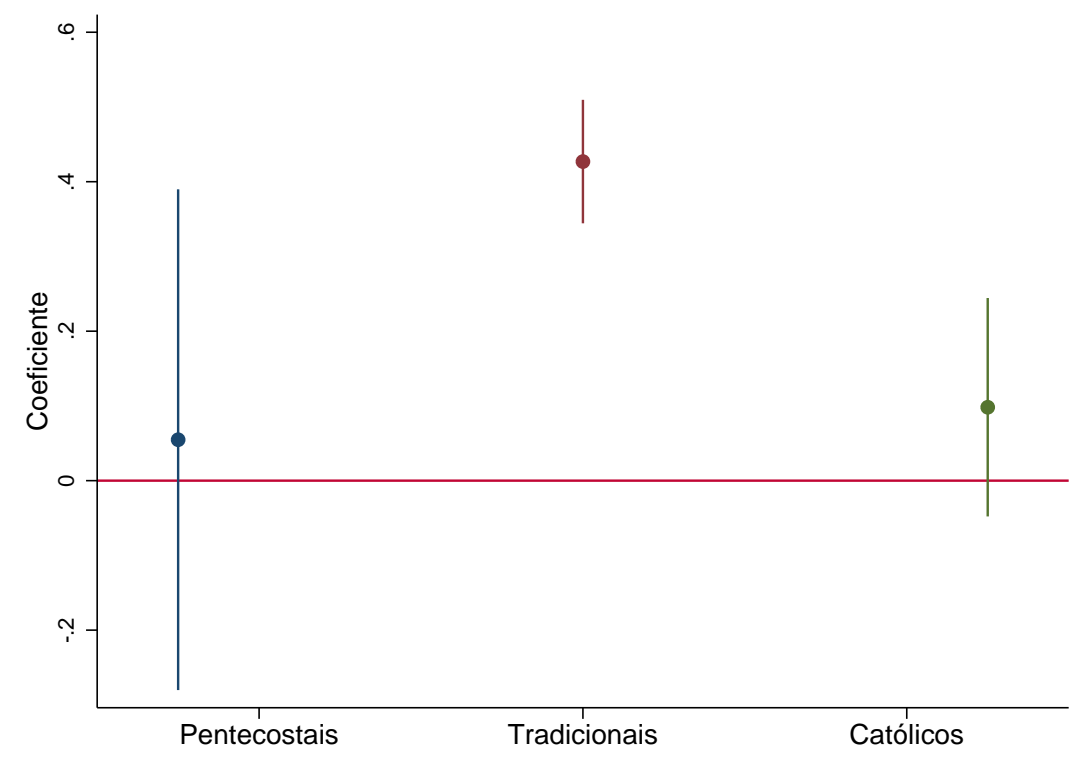

Nota: Elaborado a partir dos dados do Latin American Public Opinion Project (LAPOP, 2014). A unidade de análise é o indivíduo $(\mathrm{N}=1,571)$. Os modelos de regressão logística apresentados na figura 29 foram ajustados com erros padrões robustos, utilizando os seguintes controles: idade, sexo, renda, escolaridade, raça, nível de religiosidade e local de moradia (urbano ou rural) do indivíduo.

Os resultados da figura 29 mostram que os beneficiários pentecostais não são menos propensos a apoiar políticas redistributivas. A estimativa para este grupo é

15 A pergunta original em espanhol é a seguinte: El Estado chileno debe implementar políticas firmes para reducir la desigualdad de ingresos entre ricos y pobres. ¿Hasta qué punto está de acuerdo o en desacuerdo con esta frase? 
positiva e não significante (IC de 95\%). A estimativa do grupo católico é também não significante (embora com sinal positivo), enquanto os evangélicos tradicionais são aqueles com maior predisposição a apoiar políticas de redistribuição de renda. Vale ressaltar, também para o caso chileno, o risco dessas estimativas serem afetadas por social desirability ${ }^{16}$, o que sugere cautela na interpretação desse resultado.

O segundo mecanismo alternativo é que programas de transferência de renda como o CS podem levar seus beneficiários a perceberem menor desigualdade de renda na sociedade. Neste caso, a presunção é que a implementação do CS tenha produzido esse efeito especialmente no grupo dos evangélicos pentecostais. Por isso, os beneficiários desse grupo não teriam incentivos para votar em partidos de esquerda. Para testar essa hipótese, reestimo a equação 5.1 com uma variável dependente, $\boldsymbol{Y}_{i}$, que assume valor 1 se o indivíduo concorda que a diferença na distribuição de rendimentos é demasidamente grande, e 0 caso contrário ${ }^{17}$.

A figura 30 reporta as estimativas por filiação religiosa. Em geral, a implementação do CS não alterou a percepção de desigualdade dos beneficiários. As estimativas para os beneficiários pentecostais e católicos não são estatisticamente significativas. A estimativa para os evangélicos tradicionais é significante, mas a magnitude do efeito é pequena e indistinguível de zero. Em outros termos, os dados não sugerem diferença substantiva entre a percepção da desigualdade dos beneficiários do CS filiados aos diferentes grupos religiosos.

Por fim, é razoável supor que a renda distribuída via CS foi capaz de promover o aumento do bem-estar dos seus beneficiários. Se este fenômeno foi concentrado

16 Para uma discussão sobre como o fenômeno da social desirability afeta as medidas de preferência por redistribuição na América Latina, ver Holland (2018).

17 A pergunta original em espanhol é a seguinte: Las diferencias en los ingresos en Chile son demasiado grandes. ¿Hasta qué punto está de acuerdo o en desacuerdo? 
Figura 30 - Percepção da desigualdade dos beneficiários do CS por filiação religiosa (2014)

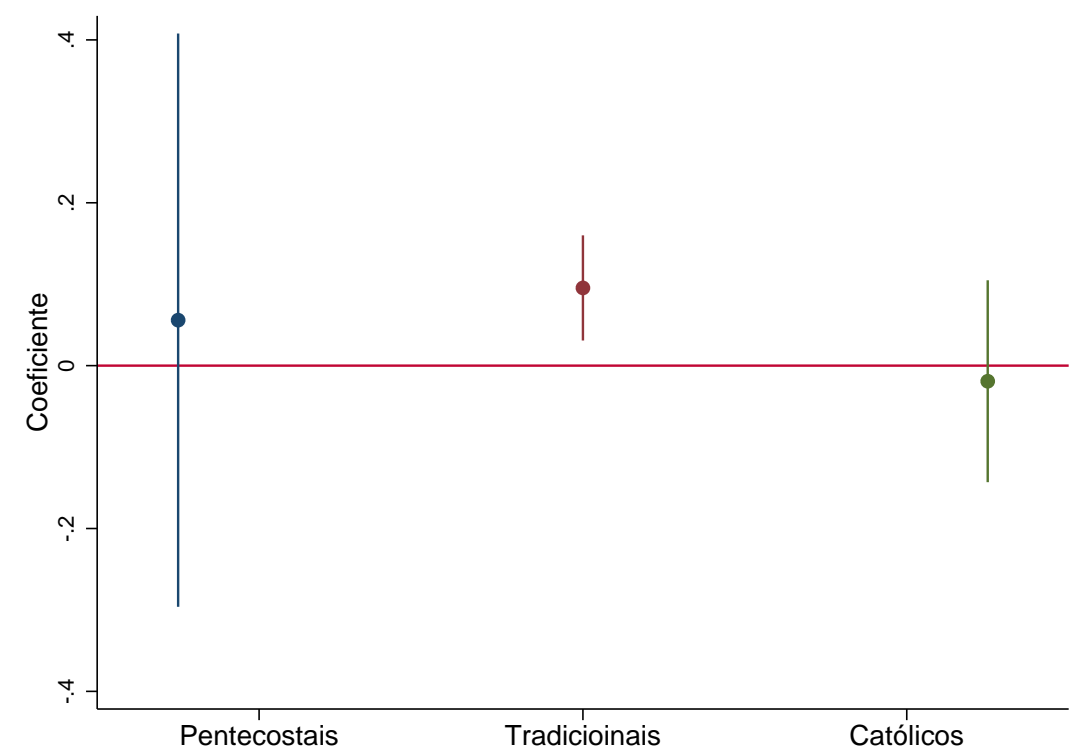

Nota: Elaborado a partir dos dados do Latin American Public Opinion Project (LAPOP, 2014). A unidade de análise é o indivíduo $(\mathrm{N}=1,571)$. Os modelos de regressão logística apresentados na figura 30 foram ajustados com erros padrões robustos, utilizando os seguintes controles: idade, sexo, renda, escolaridade, raça, nível de religiosidade e local de moradia (urbano ou rural) do indivíduo.

entre os beneficiários pentecostais, os incentivos para votar em candidatos de esquerda também deveriam ser menores. A ideia que sustenta essa hipótese é que indivíduos que experimentam ascensão social tornam-se avessos à taxação para não ter que pagar pela mobilidade social de outros pobres (PIKETTY, 1995; BENABOU; OK, 2001). Para testar esta hipótese, reestimo a equação 5.1 com uma variável dependente, $\boldsymbol{Y}_{\boldsymbol{i}}$, que assume valor 1 se o indivíduo está de acordo em pagar mais impostos se estes forem utilizados para dar mais àqueles que têm menos, e 0 caso contrário ${ }^{18}$.

A figura 31 apresenta as estimativas por filiação religiosa. As evidências não sugerem maior aversão à taxação entre os beneficiários pentecostais. As estimativas para os beneficiários evangélicos tradicionais e católicos também são estatisticamente não significantes nos níveis convencionais. O que significa que os beneficiários do

18 A pergunta original em espanhol é a seguinte: Estaría dispuesto/a a pagar más impuestos si éstos se usaran para darle más a quien tiene menos. ¿Hasta qué punto está de acuerdo o en desacuerdo? 
Figura 31 - Aversão à taxação dos beneficiários do CS por filiação religiosa (2014)

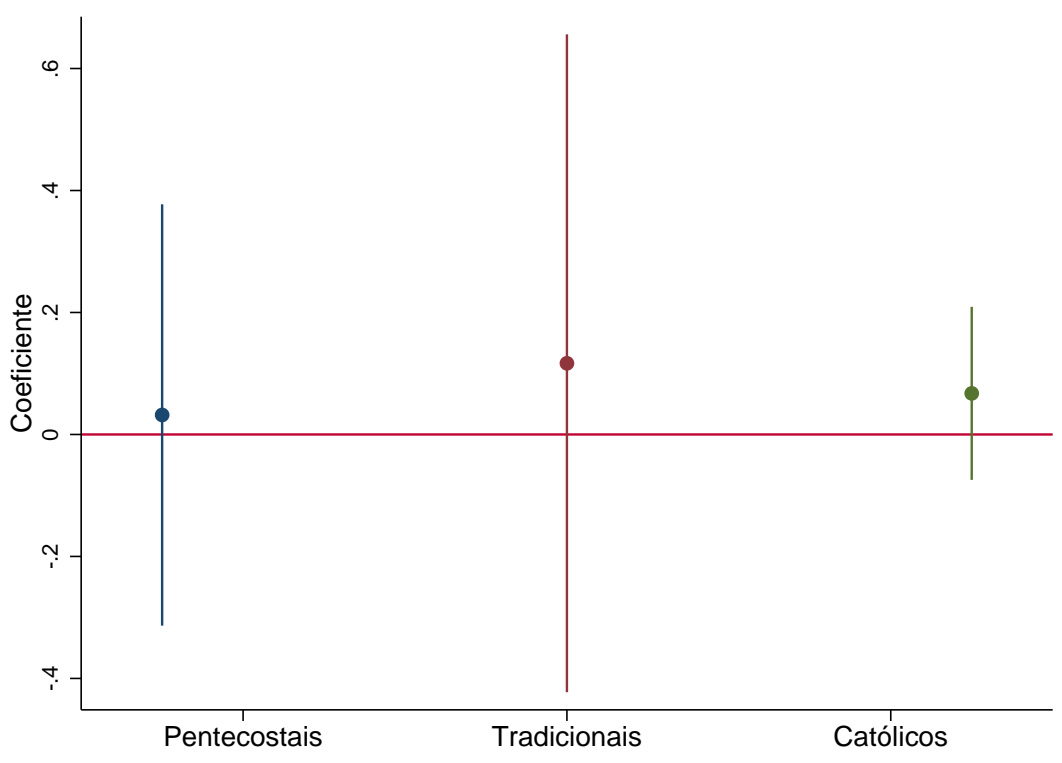

Nota: Elaborado a partir dos dados do Latin American Public Opinion Project (LAPOP, 2014). A unidade de análise é o indivíduo $(\mathrm{N}=1,571)$. Os modelos de regressão logística apresentados na figura 31 foram ajustados com erros padrões robustos utilizando os seguintes controles: idade, sexo, renda, escolaridade, raça, nível de religiosidade e local de moradia (urbano ou rural) do indivíduo.

programa CS não se tornaram mais avessos à taxação. Este resultado se aplica para todas as filiações religiosas e reforça as evidências que mostram que, na América Latina, a percepção de aumento do bem-estar social não implica redução da preferência por redistribuição (GAVIRIA; GRAHAM; BRAIDO, 2007; MÉNDEZ; WALTENBERG, 2016).

Em resumo, as evidências desta seção indicam que o caso brasileiro não deve ser considerado uma excepcionalidade. Embora os dados de nível individual não permitam estimar o efeito da transição religiosa sobre o comportamento eleitoral dos diferentes grupos religiosos, os resultados sugerem que o pentecostalismo também desempenha papel importante nas eleições presidenciais chilenas. Assim como no caso brasileiro, o conservadorismo moral utilizado para mobilizar o eleitorado pentecostal parece estar relacionado com a observância de efeitos heterogêneos das políticas de redistribuição de renda. $\mathrm{O}$ aumento do bem-estar provido pelos programas de transferência condicional de renda não necessariamente significa mais votos para os partidos responsáveis pela 
implementação desses programas. O eleitor evangélico pentecostal tende a votar a partir de sua identidade religiosa, que conflita com a identidade de renda por meio da qual o voto econômico se materializa. 



\section{Conclusão}

As previsões de que a emergência do secularismo reduziria a influência das religões nas sociedades modernas não se confirmaram. As religiões continuam desempenhando papel fundamental na esfera política. Em várias democracias, a igreja influencia políticas sobre temas diversos, desde a alfabetização de crianças, passando pelo aborto, até a provisão de políticas de bem-estar social (GILL, 2001).

Neste sentido, a ressurgência da clivagem religiosa nas eleições da Europa Ocidental tem produzido uma reorientação dos partidos para se alinhar às preferências desse eleitorado mais sensível às pautas morais (MINKENBERG, 2010). Após uma tendência de queda, observa-se um movimento de crescente influência da religião nos resultados eleitorais, sobretudo nos países marcados por forte divisão religiosa (BRUG; HOBOLT; VREESE, 2009). A distribuição do eleitorado em torno de pautas religiosas morais já tradicionais em democracias consolidadas, como Alemanha, Estados Unidos e Reino Unido (RAYMOND, 2011), vem ganhando cada vez mais centralidade também nas novas democracias do Leste Europeu (ZIC, 2017) e da África Subsariana. Neste último caso, com forte influência das igrejas pentecostais, que proliferam rapidamente no continente africano (SPERBER; HERN, 2018).

A análise empreendida neste trabalho se soma a tentativas anteriores de iluminar o debate sobre religião e política na América Latina (LEVINE, 1980; FRESTON, 2004; BOAS; SMITH, 2015; SMITH, 2019), mas com um especial enfoque nas consequências redistributivas da interação entre as duas variáveis. No Brasil, os pobres evangélicos pentecostais tendem a não votar em candidatos com propostas redistributivas. Em 
grande medida, esse resultado pode ser explicado pelo trabalho de mobilização realizado por pastores e lideranças religiosas nas igrejas pentecostais. Concentrados nas áreas pobres urbanas, os pentecostais tendem a ser menos escolarizados, menos informados e mais conservadores do que os eleitores católicos, que constituem o núcleo de apoio dos candidatos com propostas redistributivas nas eleições presidenciais brasileiras. Os evangélicos tradicionais apresentam um comportamento eleitoral menos consistente, embora os resultados apontem na direção de menor rejeição dos eleitores desse grupo aos candidatos de esquerda.

As evidências confirmam o efeito da transição religiosa sobre a votação dos partidos de esquerda. Entre 2010 e 2018, o PT obteve melhor desempenho eleitoral nos municípios que experimentaram crescimento da população católica. Isso explica, pelo menos em parte, o crescimento do partido na região Nordeste e a perda de apoio nos estados da região Centro-Sul. Ademais, em geral, o PT registrou pior desempenho eleitoral nos municípios com maioria evangélica, mas este resultado foi alavancado pelos municípios com maioria pentecostal. A categoria "evangélico" esconde heterogeneidades importantes que deveriam ser objeto de estudos futuros.

Os resultados também parecem indicar que as diferentes categorias religiosas respondem de maneiras diferentes às políticas de redistribuição de renda. $\mathrm{O}$ voto no $\mathrm{PT}$ dos beneficiários católicos do Bolsa Família contrasta com a rejeição dos beneficiários evangélicos pentecostais aos candidatos petistas. Em geral, os beneficiários com filiação evangélica pentecostal não premiam o PT pelo aumento do bem-estar promovido pela implementação do Bolsa Família. A importância desses resultados se dá pela tendência de aumento do peso eleitoral deste grupo nas eleições brasileiras. Nas eleições de 2018, esse grupo abrangia cerca de $20 \%$ do eleitorado total brasileiro e uma fração importante 
do eleitorado de baixa renda nas áreas urbanas. Além disso, as estimativas indicam que esse grupo continuará crescendo nas próximas duas décadas (ALMEIDA; BARBOSA, 2015).

As evidências sobre o caso chileno sugerem que o padrão observado no Brasil pode também se aplicar a outros contextos onde a transição religiosa está associada ao crescimento dos evangélicos pentecostais. O Partido Socialista, responsável por implementar o Chile Solidário, programa de transferência condicional de renda equivalente ao Bolsa Família no Brasil, tende a ser punido nas urnas pelos beneficiários pentecostais. Embora os resultados observados nos dois casos seja convergente, as evidências não permitem fazer generalizações para o continente latino-americano. Uma análise comparada desse fenômeno na América Latina é uma agenda para pesquisas futuras.

\section{Voto por redistribuição: uma agenda em aberto}

As conclusões deste trabalho não permitem descartar outras potenciais explicações para o intrigante comportamente eleitoral dos mais pobres. Por exemplo, a pesquisa desenvolvida por Holland (2018) na América Latina mostra que os indivíduos que se sentem descobertos pelo sistema de proteção social têm menos incentivos para votar por redistribuição. De acordo com a autora, esse sentimento de "abandono social"tende a ser mais forte entre os indivíduos fora do mercado formal de trabalho, que habitam os grandes centros urbanos em condições precárias. Na mesma linha, Beramendi e Rehm (2016) mostram que, em contextos onde o sistema tributário é fortemente regressivo, como é o caso do Brasil e grande parte dos países da América Latina ${ }^{19}$, os eleitores pobres percebem-se taxados como ricos e tendem a não votar por redistribuição.

19 Para uma análise comparada dos sistemas tributários dos países latino-americanos ver, Bernardi et al. (2013). 
Visconti (2019) aborda outra importante dimensão relacionada ao voto dos eleitores de baixa renda. De acordo com o autor, os indivíduos vítimas de crime passam a preferir candidatos com propostas ostensivas de combate ao crime. Como os pobres são mais afetados pela criminalidade, os candidatos de esquerda, geralmente mais sensíveis à agenda de direitos humanos e defensores de políticas de segurança pública de longo prazo, enfrentam dificuldades para angariar votos nesse grupo. Os achados do autor complementam evidências anteriores que sugerem baixo engajamento em atividades políticas (TRELLES; CARRERAS, 2012) e menores taxas de comparecimento eleitoral em áreas com índices elevados de criminalidade (LEY, 2018).

Por fim, evidências recentes revelam que os indivíduos relativamente pobres que se acham mais ricos do que realmente são tendem a usar o próprio padrão de vida como referência para a redistribuição. Em uma pesquisa em 10 países ${ }^{20}$ com mais de 30 mil respondentes, Hoy e Mager (2019) mostram que informar os indivíduos sobre sua real condição de pobreza tende a fortalecer a ideia de que mesmo os mais pobres possuem o mínimo necessário para sobreviver, reduzindo a demanda por mais impostos para financiar a redistribuição.

Portanto, os resultados deste trabalho retratam apenas parcialmente uma realidade mais complexa e multifacetada. A religião é um dos mecanismos capazes de explicar a rejeição dos mais pobres a propostas eleitorais redistributivas, não o único. Embora esses mecanismos possam se superpor e operar de forma concomitante, um rigoroso tratamento empírico demanda que os mesmos sejam investigados separadamente.

20 Os seguintes países integram a amostra dos autores: Austrália, África do Sul, Espanha, Estados Unidos, Índia, Holanda, México, Marrocos, Nigéria e Reino Unido. 


\section{Implicações dos resultados}

\section{Pentecostalismo e pressão eleitoral por redistribuição}

A presunção de que a desigualdade gera pressão por redistribuição se assenta na premissa básica de que partidos e eleitores são guiados pelo voto econômico. No entanto, se o pentecostalismo mobiliza parte importante do eleitorado pobre contra os partidos de esquerda, a pressão por redistribuição tende a ser baixa mesmo em contextos de alta desigualdade. Obviamente, o pentecostalismo não é a única fonte, nem mesmo o único catalisador do conservadorismo moral. O que confere ao pentecostalismo importância central nas eleições é a sua capacidade de mobilização. Pastores e líderes desse movimento detêm os meios necessários para transformar conservadorismo moral em votos.

Votar exige do eleitor uma capacidade não trivial de ordenamento de preferências. Em eleições limpas e justas, o eleitor é exposto a uma grande quantidade de informação, mas isso não significa igual capacidade de processamento. Restrições de tempo e cognição limitam a capacidade de os cidadãos absorverem e filtrarem as informações necessárias para a escolha de seus candidatos. Em primeira instância, os partidos são os agentes responsáveis por produzir atalhos informacionais que diminuem a complexidade do processo de tomada de decisão. Outros atores, como pastores e liderenças religiosas, podem assumir esse papel.

As igrejas pentecostais são um ambiente propício para o recrutamento de eleitores. A combinação de vulnerabilidade, baixo acesso à informação e conservadorismo moral permite às lideranças dessas igrejas mobilizar fiéis contra seus inimigos nas urnas. 
Mesmo assumindo certa heterogeneidade nos interesses dessas lideranças ${ }^{21}$, o resultado tende a ser a oposição aos partidos de esquerda - o que, em geral, significa não votar a favor de propostas eleitorais redistributivas.

\section{Voto identitário e estratégias político-partidárias}

O fortalecimento da identidade religiosa exige um esforço de adaptação da elite política. Para os partidos de direita, em geral mais orientados por políticas pró-mercado e, portanto, mais próximos do eleitorado de renda média e alta, adotar pautas morais pode significar também alcançar os eleitores conservadores de baixa renda. $O$ paradoxo é que essa estratégia permite a esses partidos aglutinarem o apoio de dois tipos de eleitores. Um primeiro composto por indivíduos de baixa renda que têm interesse em redistribuição, mas priorizam a agenda moral. E um segundo composto por eleitores mais ricos, em geral avessos ao aumento da taxação, e que tendem a votar contra os partidos de esquerda.

Os partidos de esquerda têm como primeira opção tentar enfraquecer a pauta moral e recolocar no centro do debate a dimensão de renda. Neste caso, existe o risco de perder apoio da parcela mais conservadora do eleitorado que não segue a lógica econômica do voto. Uma segunda opção é tentar se distanciar de pautas mais progressistas que possam minar o apoio eleitoral dos pobres conservadores. Mas existe o risco de perder apoio entre os eleitores de renda média com maior escolaridade, bem como de parte da militância organizada e representantes de grupos minoritários afetados por uma agenda política moralizante. Uma terceira opção é acirrar a polarização nas eleições, explorando a identidade religiosa do eleitorado. Por exemplo, os partidos de

21 Embora parte dessas lideranças seja sincera ao orientar o voto contra a esquerda com base em argumentos morais, é também razoável assumir que a oposição desse grupo à esquerda esconde, na verdade, a defesa de interesses organizados e privilégios para suas igrejas. 
esquerda podem mobilizar parte do eleitorado religioso em seu favor por meio de um discurso identitário. Mas o sucesso dessa estratégia depende do crescimento de longo prazo dos grupos religiosos que rivalizam nas eleições. No caso brasileiro, mobilizar o eleitorado católico contra o eleitorado evangélico pentecostal pode significar prejuízo eleitoral futuro, dado que este último grupo será maioria já na próxima década (ALVES et al., 2017).

\section{Identidade religiosa e accountability}

Em democracias, costuma-se assumir que os eleitores respondem positivamente nas urnas às políticas de aumento do bem-estar social e punem os políticos quando experimentam redução da qualidade de vida. Este mecanismo, baseado na ideia de que o eleitor é racional e vota segundo uma lógica econômica, fundamenta a ideia de accountability horizontal (O’DONNELL, 1998; PRZEWORSKI; STOKES; MANIN, 1999). Em alguns casos, porém, a identidade religiosa pode perverter essa lógica e produzir resultados eleitorais contraditórios.

Uma explicação corrente para a debilidade das democracias latino-americanas é o fato de os eleitores responderem melhor aos apelos clientelistas dos políticos (TAYLORROBINSON, 2010). Assim, não haveria incentivos para a implementação de políticas programáticas seguindo critérios públicos e universais (KEEFER, 2007). A implementação de programas de transferência de renda em países como Brasil, México e Chile foi vista por muitos como uma aposta de alto risco desses governos. Se o eleitor de baixa renda responde às politicas de redistribuição, os políticos têm incentivos para diversificar seu portfólio eleitoral e investir em estratégias programáticas para angariar votos. No caso brasileiro, os efeitos eleitorais do Bolsa Família, uma política não 
clientelista de larga escala, foram recebidos com entusiasmo. No entanto, os resultados deste trabalho contradizem, pelo menos em parte, a tese de que o PT conseguiu ampliar seu apoio eleitoral entre os mais pobres por meio do programa de transferência de renda $^{22}$. O efeito do PBF sobre a votação do PT parece ter sido concentrado entre os beneficiários católicos. Isso sugere que a religião deveria ser considerada como uma variável interveniente nas análises dos efeitos eleitorais das políticas de redistribuição de renda.

Os resultados similares observados no contexto chileno levam a crer que os eleitores que experimentam aumento do bem-estar não necessarimente retribuem o incumbente com mais votos. Na melhor das hipóteses, isso significa incentivos para que os políticos implementem programas de bem-estar com ganhos localizados no eleitorado que responde positivamente às políticas redistributivas. Na pior das hipóteses, a "ingratidão"dos eleitores de baixa renda pode contribuir, não só para a manutenção do clientelismo, mas incentivar o uso dessa estratégia eleitoral a ponto de torná-la dominante.

$\overline{22}$ Os trabalhos anteriores de Bohn (2011), Nicolau (2014) e Simoni (2017) já apontavam nessa direção. 


\section{Referências}

ABADIE, A. et al. When should you adjust standard errors for clustering? [S.1.], 2017. Citado na página 41.

ACEMOGLU, D. et al. Democracy, redistribution, and inequality. In: Handbook of income distribution. [S.1.]: Elsevier, 2015. v. 2, p. 1885-1966. Citado na página 3.

ALESINA, A.; GIULIANO, P. Preferences for redistribution. In: Handbook of social economics. [S.1.]: Elsevier, 2011. v. 1, p. 93-131. Citado na página 4.

ALESINA, A.; GLAESER, E.; GLAESER, E. L. Fighting poverty in the US and Europe: A world of difference. [S.1.]: Oxford University Press, 2004. Citado na página 4.

ALMEIDA, R.; BARBOSA, R. Transição religiosa no Brasil. In: Trajetórias das desigualdades: como o Brasil mudou nos últimos cinquenta anos. São Paulo: Editora Unesp. [S.1.: s.n.], 2015. p. 335-365. Citado 2 vezes nas páginas 22 e 107.

ALMEIDA, R. d. Religião e desigualdade urbana. Interseções, v. 13, n. 1, p. 126-135, 2011. Citado na página 20.

ALMEIDA, R. d. A onda quebrada-evangélicos e conservadorismo. Cadernos Pagu, SciELO Brasil, n. 50, 2017. Citado 4 vezes nas páginas 6, 7, 28 e 63.

ALMEIDA, R. d.; MONTEIRO, P. Trânsito religioso no Brasil. São Paulo em Perspectiva, SciELO Brasil, v. 15, n. 3, p. 92-100, 2001. Citado 2 vezes nas páginas 17 e 20.

ALVAREDO, F. et al. World inequality report 2018. [S.1.]: Belknap Press, 2018. Citado na página 1.

ALVES, J. E. D.; CAVENAGHI, S. M.; BARROS, L. F. W. A transição religiosa brasileira e o processo de difusão das filiações evangélicas no Rio de Janeiro. HORIZONTE-Revista de Estudos de Teologia e Ciências da Religião, v. 12, n. 36, p. 1055-1085, 2014. Citado na página 67.

ALVES, J. E. D. et al. Distribuição espacial da transição religiosa no Brasil. Tempo Social, v. 29, n. 2, p. 215-242, 2017. Citado 2 vezes nas páginas 17 e 111.

AMARANTE, V.; BRUN, M. Cash transfers in Latin America: effects on poverty and redistribution. Economía, Brookings Institution Press, v. 19, n. 1, p. 1-31, 2018. Citado na página 93.

ANSELIN, L. Local indicators of spatial association-lisa. Geographical analysis, Wiley Online Library, v. 27, n. 2, p. 93-115, 1995. Citado na página 51.

ARRETCHE, M.; ARAÚJO, V. O Brasil tornou-se mais conservador?: Apoio à redistribuição e à taxação no Brasil. Novos Estudos, Centro Brasileiro de Analise e Planejamento, p. 15, 2017. Citado na página 49.

ARRETCHE, M.; MARQUES, E.; FARIA, C. As Políticas da Política: Desigualdades e Inclusão nos Governos do PSDB e do PT. [S.1.]: Editora UNESP, 2019. Citado na página 88. 
AVELINO, G.; BIDERMAN, C.; BARONE, L. S. Articulações intrapartidárias e desempenho eleitoral no Brasil. Dados-Revista de Ciências Sociais, Universidade do Estado do Rio de Janeiro, v. 55, n. 4, p. 987-1013, 2012. Citado na página 64.

BAKER, A.; AMES, B.; RENNO, L. R. Social context and campaign volatility in new democracies: networks and neighborhoods in Brazil's 2002 elections. American Journal of Political Science, Wiley Online Library, v. 50, n. 2, p. 382-399, 2006. Citado 4 vezes nas páginas 74, 76, 164 e 187.

BARBOSA, C. M. R. A cruz e o lulismo: um estudo de caso na periferia de São Paulo com fiéis da Igreja Universal nas eleições de 2014. Dissertação (Mestrado) - Universidade de São Paulo, 2016. Citado na página 74.

BARBOSA, R. J. A caridade e o interesse. A construção da plausibilidade da idéia de gestão no catolicismo brasileiro. Dissertação (Mestrado) — Universidade de São Paulo, 2010. Citado na página 28.

BASSETTO, M.; BENHABIB, J. Redistribution, taxes, and the median voter. Review of Economic dynamics, Elsevier, v. 9, n. 2, p. 211-223, 2006. Citado na página 2.

BECHTEL, M. M.; HAINMUELLER, J. How lasting is voter gratitude? An analysis of the short-and long-term electoral returns to beneficial policy. American Journal of Political Science, Wiley Online Library, v. 55, n. 4, p. 852-868, 2011. Citado na página 79.

BENABOU, R.; OK, E. A. Social mobility and the demand for redistribution: the poum hypothesis. The Quarterly Journal of Economics, MIT Press, v. 116, n. 2, p. 447-487, 2001. Citado 2 vezes nas páginas 5 e 101.

BERAMENDI, P.; REHM, P. Who gives, who gains? Progressivity and preferences. Comparative Political Studies, SAGE Publications Sage CA: Los Angeles, CA, v. 49, n. 4, p. 529-563, 2016. Citado na página 107.

BERNARDI, L. et al. Tax systems and tax reforms in Latin America. [S.1.]: Routledge, 2013. Citado na página 107.

BIRMAN, P. Cultos de possessão e pentecostalismo no Brasil: passagens. Religião e sociedade, ISER Rio de Janeiro, v. 17, n. 1-2, p. 90-109, 1996. Citado na página 18.

BOAS, T.; SMITH, A. E. Religion and the latin american voter. In: The Latin American Voter. [S.1.]: University of Michigan Press Ann Arbor, 2015. p. 99-121. Citado na página 105.

BOAS, T. C. Pastor Paulo vs. Doctor Carlos: professional titles as voting heuristics in Brazil. Journal of Politics in Latin America, SAGE Publications Sage UK: London, England, v. 6, n. 2, p. 39-72, 2014. Citado na página 63.

BOAS, T. C. Pastors for Pinochet: Authoritarian stereotypes and voting for evangelicals in Chile. Journal of Experimental Political Science, Cambridge University Press, v. 3, n. 2, p. 197-205, 2016. Citado na página 92.

BOHN, S. R. Evangélicos no Brasil: perfil socioeconômico, afinidades ideológicas e determinantes do comportamento eleitoral. Opinião Pública, SciELO Brasil, v. 10, n. 2, p. 288-338, 2004. Citado na página 28. 
BOHN, S. R. Social policy and vote in Brazil: Bolsa Família and the shifts in Lula's electoral base. Latin American Research Review, JSTOR, p. 54-79, 2011. Citado na página 112.

BRADY, D.; LEICHT, K. T. Party to inequality: Right party power and income inequality in affluent western democracies. Research in Social Stratification and Mobility, Elsevier, v. 26, n. 1, p. 77-106, 2008. Citado na página 13.

BRAUW, A. D. et al. Bolsa Família and household labor supply. Economic Development and Cultural Change, University of Chicago Press Chicago, IL, v. 63, n. 3, p. 423-457, 2015. Citado na página 80.

BRUG, W. Van der; HOBOLT, S. B.; VREESE, C. H. D. Religion and party choice in Europe. West European Politics, Taylor \& Francis, v. 32, n. 6, p. 1266-1283, 2009. Citado na página 105.

BUBLITZ, E. Misperceptions of income distributions: Cross-country evidence from a randomized survey experiment. [S.1.], 2017. Citado na página 6.

CAMARGO, C. P. F.; SOUZA, B. M. de. Católicos, protestantes, espíritas. [S.1.]: Editora Vozes, 1973. Citado na página 20.

CAMPELLO, D. The politics of financial booms and crises: Evidence from Latin America. Comparative Political Studies, SAGE Publications Sage CA: Los Angeles, CA, v. 47, n. 2, p. 260-286, 2014. Citado na página 1.

CAMPOS, L. S. As origens norte-americanas do pentecostalismo brasileiro: observações sobre uma relação ainda pouco avaliada. Revista USP, n. 67, p. 100-115, 2005. Citado na página 18.

CAMPOS, L. S. Os mapas, atores e números da diversidade religiosa cristã brasileira: Católicos e Evangélicos entre 1940 e 2007. Revista de Estudos da Religião, p. 9-47, 2008. Citado 2 vezes nas páginas 6 e 7.

CANÊDO-PINHEIRO, M. Bolsa Família ou desempenho da economia? determinantes da reeleição de lula em 2006. Economia Aplicada, SciELO Brasil, v. 19, n. 1, p. 31-61, 2015. Citado na página 80.

CLEARY, E. L.; SEPÚLVEDA, J. Chilean pentecostalism: Coming of age. In: Power, politics, and pentecostals in Latin America. [S.1.]: Routledge, 2018. p. 97-121. Citado na página 93.

COUTINHO, R. Z.; GOLGHER, A. B. The changing landscape of religious affiliation in Brazil between 1980 and 2010: age, period, and cohort perspectives. Revista Brasileira de Estudos de População, SciELO Brasil, v. 31, n. 1, p. 73-98, 2014. C Citado na página 17.

CRUCES, G.; PEREZ-TRUGLIA, R.; TETAZ, M. Biased perceptions of income distribution and preferences for redistribution: Evidence from a survey experiment. Journal of Public Economics, Elsevier, v. 98, p. 100-112, 2013. Citado na página 6.

CUNHA, C. V. d. Pentecostal cultures in urban peripheries: a socio-anthropological analysis of pentecostalism in arts, grammars, crime and morality. Vibrant: Virtual Brazilian Anthropology, SciELO Brasil, v. 15, n. 1, 2018. Citado na página 20. 
CUNHA, C. V. d.; LOPES, P. V. L.; LUI, J. Religião e politica: medos sociais, extremismo religioso e as eleições 2014. [S.1.]: Rio de Janeiro: Fundação Heinrich Böll: Instituto de Estudos da Religião, 2017. Citado na página 62.

DARMOFAL, D. Spatial analysis for the social sciences. [S.1.]: Cambridge University Press, 2015. Citado na página 57.

DELAO, A. L. Do conditional cash transfers affect electoral behavior? Evidence from a randomized experiment in Mexico. American Journal of Political Science, Wiley Online Library, v. 57, n. 1, p. 1-14, 2013. Citado na página 81.

DELAO, A. L.; RODDEN, J. A. Does religion distract the poor? Income and issue voting around the world. Comparative Political Studies, Sage Publications Sage CA: Los Angeles, CA, v. 41, n. 4-5, p. 437-476, 2008. Citado na página 6.

DELGADO, L. d. A. N.; PASSOS, M. Catolicismo: direitos sociais e direitos humanos (1960-1970). In: O tempo da ditadura-regime militar e movimentos sociais em fins do século XX. Rio de Janeiro: Civilização Brasileira. [S.1.: s.n.], 2007. p. 95-131. Citado na página 27.

DRUKKER, D. M.; EGGER, P.; PRUCHA, I. R. On two-step estimation of a spatial autoregressive model with autoregressive disturbances and endogenous regressors. Econometric Reviews, Taylor \& Francis, v. 32, n. 5-6, p. 686-733, 2013. Citado na página 57.

DUVERGER, M. Political parties: Their organization and activity in the modern state. [S.1.]: Methuen, 1959. Citado na página 91.

ESPING-ANDERSEN, G. Politics against markets: The social democratic road to power. [S.1.]: Princeton University Press, 2017. v. 4877. Citado na página 13.

FAJARDO, M. P. Pentecostalismo, urbanização e periferia: perspectivas teóricas. PARALELLUS Revista de Estudos de Religião-UNICAP, v. 2, n. 4, p. 181-192, 2011. Citado na página 17.

FERNALD, L. C.; GERTLER, P. J.; NEUFELD, L. M. Role of cash in conditional cash transfer programmes for child health, growth, and development: an analysis of mexico's oportunidades. The Lancet, Elsevier, v. 371, n. 9615, p. 828-837, 2008. Citado na página 81.

FONSECA, A. B. C. Secularização, pluralismo religioso e democracia no Brasil: um estudo sobre a participação dos principais atores evangélicos na política (1998-2001). Tese (Doutorado) — Universidade de São Paulo, 2002. Citado na página 62.

FOXLEY, A.; ANINAT, E.; ARELLANO, J. P. Redistributive effects of government programmes: The Chilean case. [S.1.]: Elsevier, 2013. Citado na página 92.

FRESTON, P. Breve história do pentecostalismo brasileiro. [S.1.: s.n.], 1994. 67-159 p. Citado 3 vezes nas páginas 19, 20 e 73 .

FRESTON, P. Evangelicals and Politics in Asia, Africa and Latin America. [S.1.]: Cambridge University Press, 2004. Citado 3 vezes nas páginas 6, 7 e 105.

FRESTON, P. Religião e política, sim igreja e estado, não: os evangélicos e a participação política. [S.1.]: Ultimato, 2006. Citado 2 vezes nas páginas 10 e 20. 
FRESTON, P. Evangelical christianity and democracy in Latin America. [S.1.]: Oxford University Press, 2008. Citado na página 17.

FRESTON, P. As duas transições futuras: católicos, protestantes e sociedade na América Latina. Ciencias Sociales y Religión/Ciências Sociais e Religião, v. 12, n. 12, p. 13-30, 2010. Citado 3 vezes nas páginas 17, 20 e 93.

FUJIWARA, T. et al. A regression discontinuity test of strategic voting and duverger's law. Quarterly Journal of Political Science, Now Publishers, Inc., v. 6, n. 3-4, p. 197-233, 2011. Citado na página 91.

GALASSO, E. Alleviating extreme poverty in chile: the short term effects of chile solidario. Estudios de Economía, v. 38, n. 1, p. 101, 2011. Citado na página 93.

GAVIRIA, A.; GRAHAM, C.; BRAIDO, L. H. Social mobility and preferences for redistribution in Latin America [with comments]. Economía, JSTOR, v. 8, n. 1, p. 55-96, 2007. Citado na página 102.

GEORGE, T. Teologia dos reformadores. [S.1.]: Vida Nova, 1993. Citado na página 9.

GETIS, A.; ORD, J. K. The analysis of spatial association by use of distance statistics. In: Perspectives on Spatial Data Analysis. [S.1.]: Springer, 2010. p. 127-145. Citado na página 52.

GILL, A. Religion and comparative politics. Annual Review of Political Science, Annual Reviews, v. 4, n. 1, p. 117-138, 2001. Citado na página 105.

GIMPELSON, V.; TREISMAN, D. Misperceiving inequality. Economics E Politics, Wiley Online Library, v. 30, n. 1, p. 27-54, 2018. Citado na página 6.

GOLDEN, M.; MIN, B. Distributive politics around the world. Annual Review of Political Science, v. 16, 2013. Citado na página 63.

GRUGEL, J.; RIGGIROZZI, P. Post-neoliberalism in Latin America: Rebuilding and reclaiming the state after crisis. Development and change, Wiley Online Library, v. 43, n. 1, p. 1-21, 2012. Citado na página 1.

GRZYMALA-BUSSE, A. Why comparative politics should take religion (more) seriously. Annual Review of Political Science, Annual Reviews, v. 15, p. 421-442, 2012. Citado na página 11.

HARDING, R.; STASAVAGE, D. What democracy does (and doesn't do) for basic services: School fees, school inputs, and african elections. The Journal of Politics, Cambridge University Press New York, USA, v. 76, n. 1, p. 229-245, 2013. Citado na página 79.

HAUSER, O. P.; NORTON, M. I. (mis) perceptions of inequality. Current Opinion in Psychology, Elsevier, v. 18, p. 21-25, 2017. Citado na página 5.

HIDALGO, F. D.; NICHTER, S. Voter buying: Shaping the electorate through clientelism. American Journal of Political Science, Wiley Online Library, v. 60, n. 2, p. 436-455, 2016. Citado na página 64. 
HOLLAND, A. C. Diminished expectations: Redistributive preferences in truncated welfare states. World Politics, Cambridge University Press, v. 70, n. 4, p. 555-594, 2018. Citado 2 vezes nas páginas 100 e 107.

HOLLAND, A. C.; PALMER-RUBIN, B. Beyond the machine: clientelist brokers and interest organizations in latin america. Comparative Political Studies, SAGE Publications Sage CA: Los Angeles, CA, v. 48, n. 9, p. 1186-1223, 2015. Citado na página 64.

HOY, C.; MAGER, F. Why are relatively poor people not more supportive of redistribution? Evidence from a survey experiment across 10 countries. [S.1.], 2019. Citado na página 108.

HUBER, E.; RAGIN, C.; STEPHENS, J. D. Social democracy, christian democracy, constitutional structure, and the welfare state. American Journal of Sociology, University of Chicago Press, v. 99, n. 3, p. 711-749, 1993. Citado na página 13.

HUBER, E.; STEPHENS, J. D. Democracy and the left: social policy and inequality in Latin America. [S.1.]: University of Chicago Press, 2012. Citado 2 vezes nas páginas 1 e 13.

HUBER, J. D. Exclusion by elections: inequality, ethnic identity, and democracy. [S.1.]: Cambridge University Press, 2017. Citado na página 11.

HUBER, J. D.; STANIG, P. Church-state separation and redistribution. Journal of Public Economics, Elsevier, v. 95, n. 7-8, p. 828-836, 2011. Citado na página 6.

HUNTER, W.; POWER, T. J. Rewarding Lula: Executive power, social policy, and the brazilian elections of 2006. Latin American Politics and Society, Cambridge University Press, v. 49, n. 1, p. 1-30, 2007. Citado 2 vezes nas páginas 37 e 80.

IVERSEN, T.; SOSKICE, D. An asset theory of social policy preferences. American Political Science Review, Cambridge University Press, v. 95, n. 4, p. 875-893, 2001. Citado na página 2.

IZUMI, M. Y. Ideologia, sofisticação política e voto no Brasil. Opinião Pública, SciELO Brasil, v. 25, n. 1, p. 29-62, 2019. Citado na página 12.

JACOB, C. R.; HEES, D. R.; WANIEZ, P. Religião e território no Brasil: 1991/2010. PUC-Rio, 2013. Citado na página 17.

JORDAN, J. Religious belief, religious denomination, and preferences for redistribution: a comparison across 13 countries. West European Politics, Taylor \& Francis, v. 37, n. 1, p. 19-41, 2014. Citado na página 6.

KALIL, I. Quem são e no que acreditam os eleitores de Jair Bolsonaro. [S.1.], 2018. Citado na página 31.

KEEFER, P. Clientelism, credibility, and the policy choices of young democracies. American Journal of Political Science, Wiley Online Library, v. 51, n. 4, p. 804-821, 2007. Citado na página 111.

KING, G.; FOX, J. A solution to the ecological inference problem: Reconstructing individual behavior from aggregate data. Canadian Journal of Sociology, v. 24, n. 1, p. 150, 1999. Citado na página 37. 
KONDO, K. Hot and cold spot analysis using stata. The Stata Journal, SAGE Publications, v. 16, n. 3, p. 613-631, 2016. Citado 4 vezes nas páginas 52, 53, 55 e 139.

LACERDA, F. Assessing the strength of pentecostal churches' electoral support:

Evidence from Brazil. Journal of Politics in Latin America, SAGE Publications Sage UK: London, England, v. 10, n. 2, p. 3-40, 2018. Citado na página 63.

LAKE, D. A.; BAUM, M. A. The invisible hand of democracy: political control and the provision of public services. Comparative Political Studies, Sage Publications Thousand Oaks, v. 34, n. 6, p. 587-621, 2001. Citado na página 79.

LAVALLE, A. G.; CASTELLO, G. As benesses desse mundo: associativismo religioso e inclusão socioeconômica. Novos Estudos, v. 68, p. 73-93, 2004. Citado na página 20.

LEVINE, D. H. Churches and politics in Latin America. [S.1.]: SAGE publications Beverly Hill-London, 1980. Citado na página 105.

LEWIS-BECK, M. S.; PALDAM, M. Economic voting: an introduction. Electoral studies, Pergamon, v. 19, n. 2-3, p. 113-121, 2000. Citado na página 79.

LEY, S. To vote or not to vote: how criminal violence shapes electoral participation. Journal of Conflict Resolution, SAGE Publications Sage CA: Los Angeles, CA, v. 62, n. 9, p. 1963-1990, 2018. Citado na página 108.

LICIO, E. C.; RENNÓ, L. R.; CASTRO, H. C. Bolsa Família e voto na eleição presidencial de 2006: em busca do elo perdido. Opinião Pública, SciELO Brasil, v. 15, n. 1, p. 31-54, 2009. Citado na página 80.

LIMONGI, F. Fazendo eleitores e eleições: Mobilização política e democracia no Brasil Pós-Estado Novo. Dados-Revista de Ciências Sociais, Universidade do Estado do Rio de Janeiro, v. 58, n. 2, p. 371-400, 2015. Citado na página 64.

LINDBERG, C. The Reformation theologians: an introduction to theology in the early modern period. [S.1.]: John Wiley \& Sons, 2017. Citado na página 7.

LUPU, N.; PONTUSSON, J. The structure of inequality and the politics of redistribution. American Political Science Review, Cambridge University Press, v. 105, n. 2, p. 316-336, 2011. Citado na página 4.

LUSTIG, N. C. Coping with austerity: Poverty and inequality in Latin America. [S.1.]: Brookings Institution Press, 2010. Citado na página 80.

MACHADO, M. Política e religião: a participação dos evangélicos nas eleições. [S.1.]: FGV Editora, 2006. Citado 3 vezes nas páginas 18, 19 e 20.

MACHADO, M. Religion and moral conservatism in brazilian politics. Religion and Politics, Center for the Study of Religion and Religious Tolerance, v. 12, n. 1, p. 55-74, 2018. Citado 2 vezes nas páginas 28 e 63.

MACHADO, M. d. D.; BURITY, J. A ascensão política dos pentecostais no Brasil na avaliação de líderes religiosos. Dados-Revista de Ciências Sociais, Universidade do Estado do Rio de Janeiro, v. 57, n. 3, 2014. Citado na página 63. 
MANI, A.; MUKAND, S. Democracy, visibility and public good provision. Journal of Development Economics, Elsevier, v. 83, n. 2, p. 506-529, 2007. Citado na página 79.

MARIANO, R. Neopentecostais: sociologia do novo pentecostalismo no Brasil. [S.1.]: Edições Loyola, 1999. Citado 3 vezes nas páginas 6, 7 e 73.

MARIANO, R. Expansão pentecostal no Brasil: o caso da Igreja Universal. Estudos avançados, SciELO Brasil, v. 18, n. 52, p. 121-138, 2004. Citado na página 73.

MARIANO, R. Crescimento pentecostal no Brasil: fatores internos. Revista de Estudos da Religião, v. 4, 2008. Citado na página 18.

MARIANO, R.; PIERUCCI, A. F. O envolvimento dos pentecostais na eleição de Collor. Novos Estudos, Centro Brasileiro de Análise e Planejamento, v. 2, n. 34, p. 92-106, 1992. Citado na página 61.

MARIZ, C. L. A renovação carismática católica uma igreja dentro da igreja? Civitas-Revista de Ciências Sociais, Pontifícia Universidade Católica do Rio Grande do Sul, v. 3, n. 1, p. 169-186, 2003. Citado na página 28.

MARQUES, E. Redes sociais, segregação e pobreza. [S.1.]: Editora Unesp, 2010. Citado na página 20.

MARTORANO, B.; SANFILIPPO, M. Innovative features in poverty reduction programmes: An impact evaluation of Chile Solidario on households and children. Journal of International Development, Wiley Online Library, v. 24, n. 8, p. 1030-1041, 2012. Citado na página 93.

MATOS, A. S. Breve história do protestantismo no Brasil. Vox Faifae: Revista de Teologia da Faculdade FASSEB, v. 3, n. 1, 2011. Citado 2 vezes nas páginas 17 e 19.

MATOS, A. S. de. O movimento pentecostal: Reflexões a propósito do seu primeiro centenário. Fides Reformata, 2006. Citado 3 vezes nas páginas 9, 19 e 22.

MCCARTY, N.; POOLE, K. T.; ROSENTHAL, H. Polarized America: The dance of ideology and unequal riches. [S.1.]: MIT Press, 2016. Citado na página 13.

MELTZER, A. H.; RICHARD, S. F. A rational theory of the size of government. Journal of Political Economy, The University of Chicago Press, v. 89, n. 5, p. 914-927, 1981. Citado 2 vezes nas páginas 2 e 5 .

MÉNDEZ, Y. S.; WALTENBERG, F. D. Aversão à desigualdade e preferências por redistribuição: A percepção de mobilidade econômica as afeta no Brasil? Estudos Econômicos (São Paulo), SciELO Brasil, v. 46, n. 1, p. 91-125, 2016. Citado na página 102.

MINKENBERG, M. Party politics, religion and elections in western democracies. Comparative European Politics, Springer, v. 8, n. 4, p. 385-414, 2010. Citado na página 105.

NETTO, G. F.; SPECK, B. W. O dinheiro importa menos para os candidatos evangélicos? Opinião Pública, v. 23, n. 3, p. 809-836, 2017. Citado na página 63.

NICHTER, S. Vote buying or turnout buying? machine politics and the secret ballot. American Political Science Review, Cambridge University Press, v. 102, n. 1, p. 19-31, 2008. Citado na página 64. 
NICOLAU, J. Determinantes do voto no primeiro turno das eleições presidenciais brasileiras de 2010: uma análise exploratória. Opinião Pública, SciELO Brasil, v. 20, n. 3, p. 311-325, 2014. Citado na página 112.

NICOLAU, J.; PEIXOTO, V. As bases municipais da votação de Lula em 2006. Cadernos do Fórum Nacional, Instituto Nacional de Altos Estudos Rio de Janeiro, v. 6, p. 15-25, 2007. Citado 2 vezes nas páginas 80 e 82 .

NOVAES, L. M. Disloyal brokers and weak parties. American Journal of Political Science, Wiley Online Library, v. 62, n. 1, p. 84-98, 2018. Citado na página 64.

O'DONNELL, G. A. Horizontal accountability in new democracies. Journal of Democracy, Johns Hopkins University Press, v. 9, n. 3, p. 112-126, 1998. Citado na página 111.

ORO, A. P.; MARIANO, R. Eleições 2010: religião e política no Rio Grande do Sul e no Brasil. Debates do NER. Porto Alegre. Vol. 11, n. 18 (jul./dez. 2010), p. 11-38, 2010. Citado na página 62.

PAMPEL, F. C. Logistic regression: A primer. [S.1.]: Sage, 2000. Citado na página 25.

PIERUCCI, A. F. "Bye bye, Brasil": o declínio das religiões tradicionais no censo 2000. Estudos avançados, SciELO Brasil, v. 18, n. 52, p. 17-28, 2004. Citado na página 17.

PIERUCCI, A. F. Eleição 2010: desmoralização eleitoral do moralismo religioso. Novos estudos CEBRAP, SciELO Brasil, n. 89, p. 6-15, 2011. Citado 2 vezes nas páginas 9 e 10.

PIERUCCI, A. F.; PRANDI, R. Religiões e voto: a eleição presidencial de 1994. Opinião Pública, v. 3, n. 1, p. 32-63, 1995. Citado na página 62.

PIKETTY, T. Social mobility and redistributive politics. The Quarterly Journal of Economics, MIT Press, v. 110, n. 3, p. 551-584, 1995. Citado 2 vezes nas páginas 4 e 101.

PRANDI, R.; SANTOS, R. W. dos; BONATO, M. Igrejas evangélicas como máquinas eleitorais no Brasil. Revista USP, n. 120, p. 43-60, 2019. Citado na página 10.

PRZEWORSKI, A.; STOKES, S. C.; MANIN, B. Democracy, accountability, and representation. [S.1.]: Cambridge University Press, 1999. v. 2. Citado 2 vezes nas páginas 2 e 111.

RASELLA, D. et al. Effect of a conditional cash transfer programme on childhood mortality: a nationwide analysis of brazilian municipalities. The Lancet, Elsevier, v. 382, n. 9886, p. 57-64, 2013. Citado na página 80.

RAYMOND, C. The continued salience of religious voting in the United States, Germany, and Great Britain. Electoral Studies, Elsevier, v. 30, n. 1, p. 125-135, 2011. Citado na página 105.

REIS, B. P. Da democracia participativa à pluralidade da representação: breves notas sobre a odisseia do PT na política e na ciência política brasileira. Sociedade e Estado, SciELO Brasil, v. 29, n. 1, p. 113-127, 2014. Citado na página 4.

RIVERA, P. B. Festa, corpo e culto no pentecostalismo: notas para uma antropologia do corpo no protestantismo latino-americano. Numen, v. 8, n. 2, 2005. Citado na página 20. 
RODRIGUES-SILVEIRA, R.; CERVI, E. Evangélicos e voto legislativo: Diversidade confessional e voto em deputados da bancada evangélica no Brasil. Latin American Research Review, LASA research of commons, v. 53, n. 3, p. 560-573, 2019. Citado na página 63.

ROSAS, N. "Dominação" evangélica no Brasil: o caso do grupo musical Diante do Trono. Revista Semestral do Departamento e do Programa de Pós-Graduação em Sociologia da UFSCar, v. 5, n. 1, p. 235, 2015. Citado 2 vezes nas páginas 26 e 40.

ROSAS, N.; MUNIZ, J. O. O hábito faz o monge? Frequência e autopercepção religiosas no Brasil. Mediações-Revista de Ciências Sociais, v. 19, n. 1, p. 187-213, 2014. Citado na página 25.

RUEDA, D.; STEGMUELLER, D. The externalities of inequality: Fear of crime and preferences for redistribution in Wwestern Europe. American Journal of Political Science, Wiley Online Library, v. 60, n. 2, p. 472-489, 2016. Citado na página 2.

SAMUELS, D. J.; ZUCCO, C. Partisans, antipartisans, and nonpartisans: Voting behavior in Brazil. [S.1.]: Cambridge University Press, 2018. Citado na página 31.

SCARLATO, M.; D'AGOSTINO, G.; CAPPARUCCI, F. Evaluating conditional cash transfers from a gender perspective: the impact of chile solidario on women's employment prospect. Journal of International Development, Wiley Online Library, v. 28, n. 2, p. 177-197, 2016. Citado na página 93.

SCHEVE, K.; STASAVAGE, D. Religion and preferences for social insurance. Quarterly Journal of Political Science, Now Publishers, Inc., v. 1, n. 3, p. 255-286, 2006. Citado na página 6.

SIAVELIS, P. Chile: The unexpected (and expected) consequences of electoral engineering. In: The politics of electoral systems. [S.1.: s.n.], 2005. p. 433-52. Citado na página 91.

SIMONI, S. Política distributiva e competição presidencial no Brasil: Programa Bolsa-Família e a tese do realinhamento eleitoral. Tese (Doutorado) - Universidade de São Paulo, 2017. Citado na página 112.

SMITH, A. E. Religion and Brazilian Democracy: Mobilizing the People of God. [S.1.]: Cambridge University Press, 2019. Citado 2 vezes nas páginas 10 e 105.

SOARES, F. V.; RIBAS, R. P.; OSÓRIO, R. G. Evaluating the impact of Brazil's Bolsa Familia: Cash transfer programs in comparative perspective. Latin American Research Review, JSTOR, p. 173-190, 2010. Citado na página 80.

SOARES, G. A. D.; TERRON, S. L. Dois Lulas: a geografia eleitoral da reeleição (explorando conceitos, métodos e técnicas de análise geoespacial). Opinião Pública, SciELO Brasil, v. 14, n. 2, p. 269-301, 2008. Citado 2 vezes nas páginas 37 e 80.

SOUZA, A. Meandros da força política evangélica no brasil. Revista cultura y religión, Universidad de Arturo Prat, v. 7, n. 2, p. 117, 2013. Citado 2 vezes nas páginas 62 e 73.

SOUZA, E. C. B. d.; MAGALHÃES, M. D. B. d. Os pentecostais: entre a fé e a política. Revista Brasileira de História, SciELO Brasil, v. 22, n. 43, p. 85-105, 2002. Citado na página 9. 
SPERBER, E.; HERN, E. Pentecostal identity and citizen engagement in Sub-saharan Africa: New evidence from Zambia. Politics and Religion, Cambridge University Press, v. 11, n. 4, p. 830-862, 2018. Citado na página 105.

STARK, R.; FINKE, R. Acts of faith: Explaining the human side of religion. [S.1.]: Univ of California Press, 2000. Citado na página 11.

STASAVAGE, D. Democracy and education spending in Africa. American Journal of Political Science, Wiley Online Library, v. 49, n. 2, p. 343-358, 2005. Citado na página 79.

STEGMUELLER, D. Religion and redistributive voting in Western Europe. The Journal of Politics, Cambridge University Press New York, USA, v. 75, n. 4, p. 1064-1076, 2013. Citado na página 6.

STOKES, S. C. Perverse accountability: A formal model of machine politics with evidence from Argentina. American Political Science Review, Cambridge University Press, v. 99, n. 3, p. 315-325, 2005. Citado na página 63.

TAYLOR-ROBINSON, M. M. Do the poor count?: democratic institutions and accountability in a context of poverty. [S.1.]: Penn State Press, 2010. Citado na página 111.

TRELLES, A.; CARRERAS, M. Bullets and votes: Violence and electoral participation in Mexico. Journal of Politics in Latin America, SAGE Publications Sage UK: London, England, v. 4, n. 2, p. 89-123, 2012. Citado na página 108.

VALLE, E. A renovação carismática católica: algumas observações. Estudos Avançados, SciELO Brasil, v. 18, n. 52, p. 97-107, 2004. Citado na página 28.

VALLE, V. S. M. d. Religião, lulismo e voto: a atuação política de uma Assembleia de Deus e seus fiéis em São Paulo-2014-2016. Tese (Doutorado) — Universidade de São Paulo, 2018. Citado na página 66.

VISCONTI, G. Policy preferences after crime victimization: Panel and survey evidence from Latin America. British Journal of Political Science, Cambridge University Press, p. 1-15, 2019. Citado na página 108.

WALD, K. D.; SILVERMAN, A. L.; FRIDY, K. S. Making sense of religion in political life. Annu. Rev. Polit. Sci., v. 8, p. 121-143, 2005. Citado na página 11.

WEYLAND, K.; MADRID, R. L.; HUNTER, W. Leftist governments in Latin America: Successes and shortcomings. [S.1.]: Cambridge University Press, 2010. Citado na página 1.

WIBBELS, E.; ROBERTS, K. The politics of economic crisis in Latin America. Studies in comparative international development, Springer, v. 45, n. 4, p. 383-409, 2010. Citado na página 1.

ZIC, B. The political impact of displacement: Wartime idps, religiosity, and post-war politics in bosnia. Politics and Religion, Cambridge University Press, v. 10, n. 4, p. 862-886, 2017. Citado na página 105.

ZUCCO, C. When payouts pay off: Conditional cash transfers and voting behavior in Brazil 2002-10. American Journal of Political Science, Wiley Online Library, v. 57, n. 4, p. 810-822, 2013. Citado na página 81. 
ZUCCO, C. The impacts of conditional cash transfers in four presidential elections (2002-2014). Brazilian Political Science Review, SciELO Brasil, v. 9, n. 1, p. 135-149, 2015. Citado na página 80. 
Apêndices 



\section{APÊNDICE A - Urbanização,}

\section{desigualdade e filiação religiosa}

Figura 32 - Relação entre urbanização, desigualdade e filiação religiosa evangélica pentecostal (2000 e 2010)

2000



2000

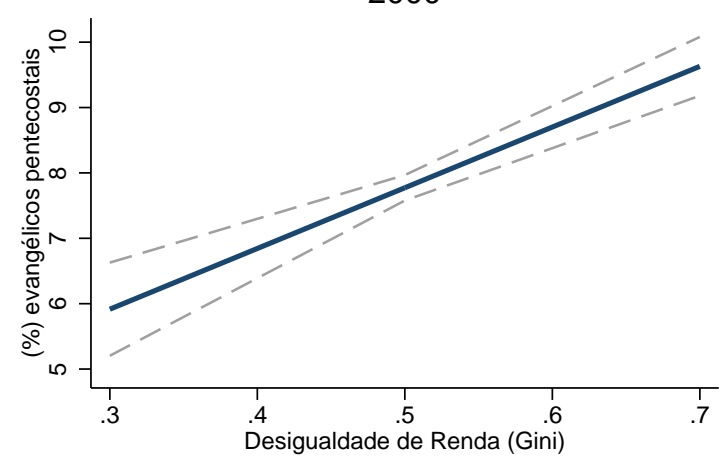

2010

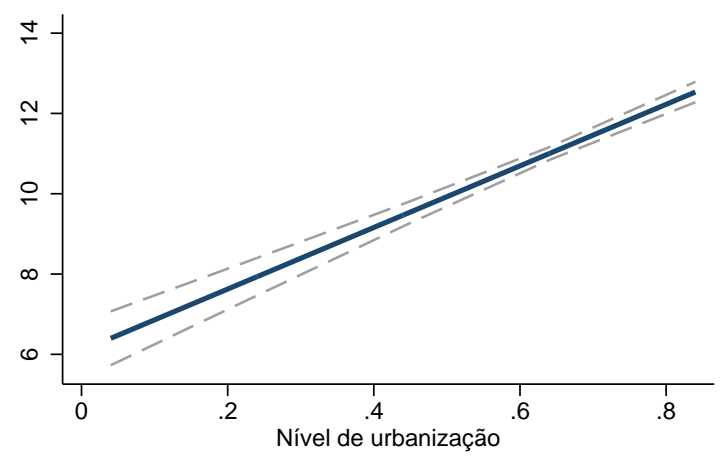

2010



Nota: elaborado pelo autor a partir dos dados do Instituto Brasileiro de Geografia e Estatística (IBGE). O eixo Y representa a proporção predita de evangélicos pentecostais nos municípios brasileiros (2000 e 2010). O eixo X representa o nível de urbanização e a desigualdade de renda nos municípios brasileiros (2000 e 2010). Um modelo de mínimos quadrados ordinários foi estimado para cada ano censitário (2000 e 2010) utilizando os seguintes controles: proporção de mulheres, expectativa de anos de estudo, renda média per capita dos mais pobres, população economicamente ativa (PEA), Índice de Desenvolvimento Humano Municipal (IDHM) e região do município. Os erros padrões são clusterizados no nível do município. 
Figura 33 - Relação entre urbanização, desigualdade e filiação religiosa evangélica tradicional (2000 e 2010)

2000

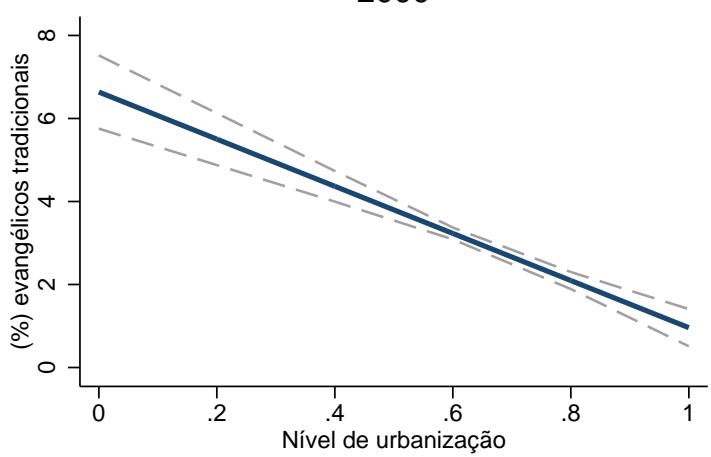

2000

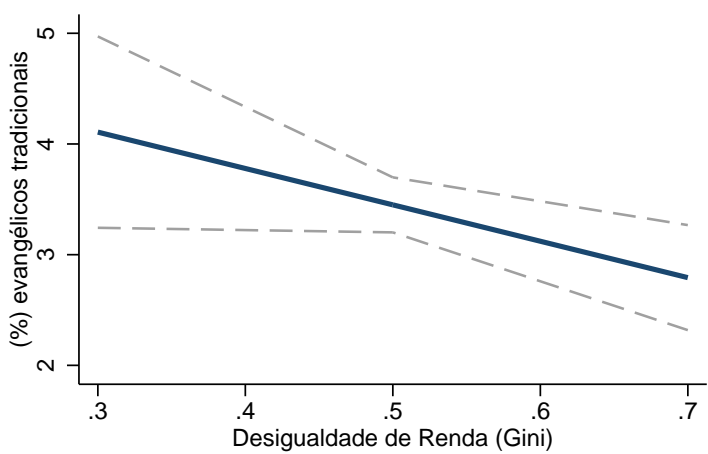

2010

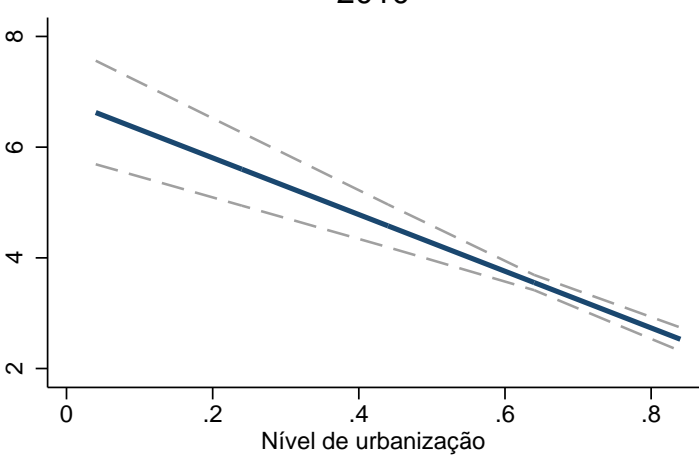

2010



Nota: elaborado pelo autor a partir dos dados do Instituto Brasileiro de Geografia e Estatística (IBGE). O eixo Y representa a proporção predita de evangélicos tradicionais nos municípios brasileiros (2000 e 2010). O eixo X representa o nível de urbanização e a desigualdade de renda nos municípios brasileiros (2000 e 2010). Um modelo de mínimos quadrados ordinários foi estimado para cada ano censitário (2000 e 2010) utilizando os seguintes controles: proporção de mulheres, expectativa de anos de estudo, renda média per capita dos mais pobres, população economicamente ativa (PEA), Índice de Desenvolvimento Humano Municipal (IDHM) e região do município. Os erros padrões são clusterizados no nível do município. 
Figura 34 - Relação entre urbanização, desigualdade e filiação religiosa católica (2000 e 2010)
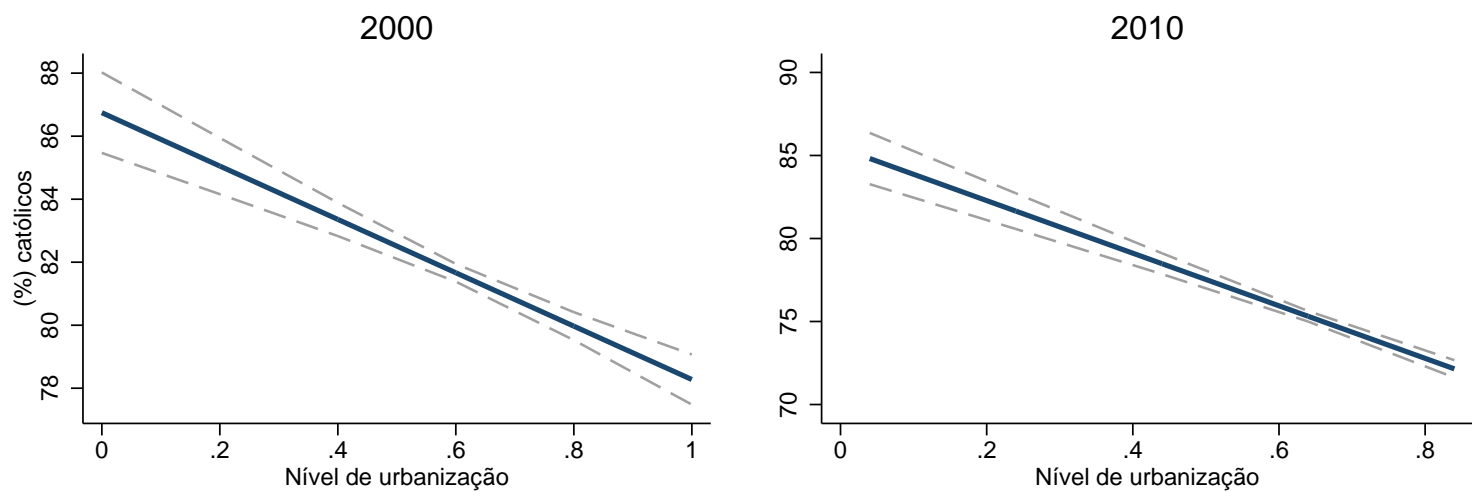

2000
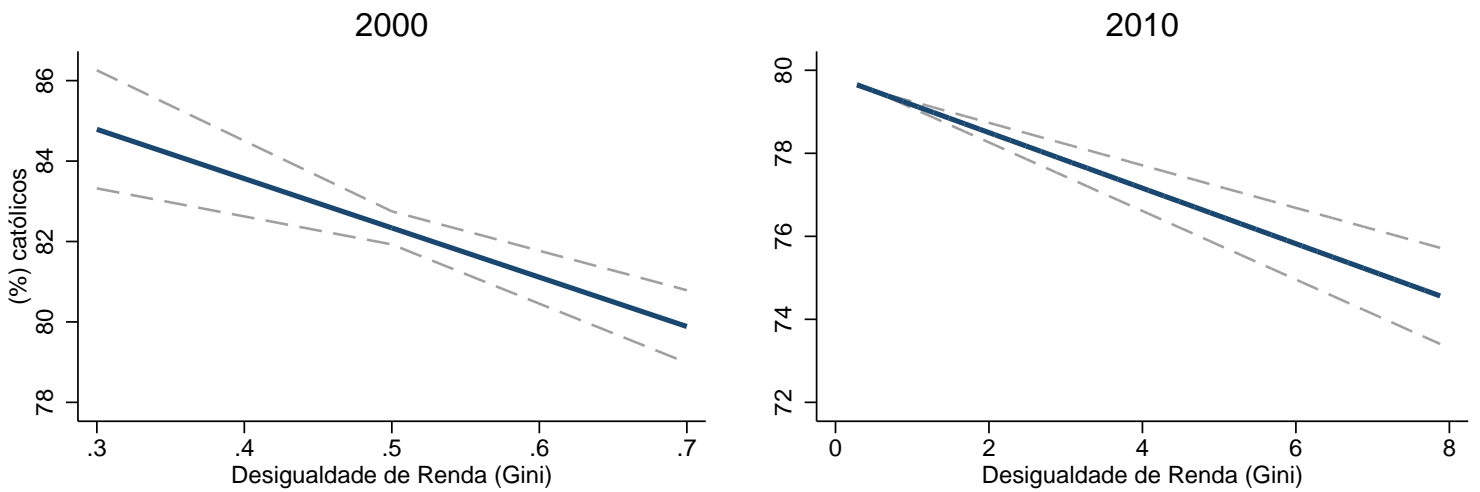

Nota: elaborado pelo autor a partir dos dados do Instituto Brasileiro de Geografia e Estatística (IBGE). O eixo Y representa a proporção predita de católicos nos municípios brasileiros (2000 e 2010). O eixo X representa o nível de urbanização e a desigualdade de renda nos municípios brasileiros (2000 e 2010). Um modelo de mínimos quadrados ordinários foi estimado para cada ano censitário (2000 e 2010) utilizando os seguintes controles: proporção de mulheres, expectativa de anos de estudo, renda média per capita dos mais pobres, população economicamente ativa (PEA), Índice de Desenvolvimento Humano Municipal (IDHM) e região do município. Os erros padrões são clusterizados no nível do município. 



\section{APÊNDICE B - Voto no território}

\section{brasileiro}

Figura 35 - Distribuição espacial da votação do PSDB nas eleições presidenciais (2006)



Nota: elaborado pelo autor a partir dos dados do Tribunal Superior Eleitoral (TSE). O mapa reporta o percentual de votos válidos do PSDB (segundo turno) em cada município brasileiro $(\mathrm{N}=5,565)$. 
Figura 36 - Distribuição espacial da votação do PSDB nas eleições presidenciais (2010)

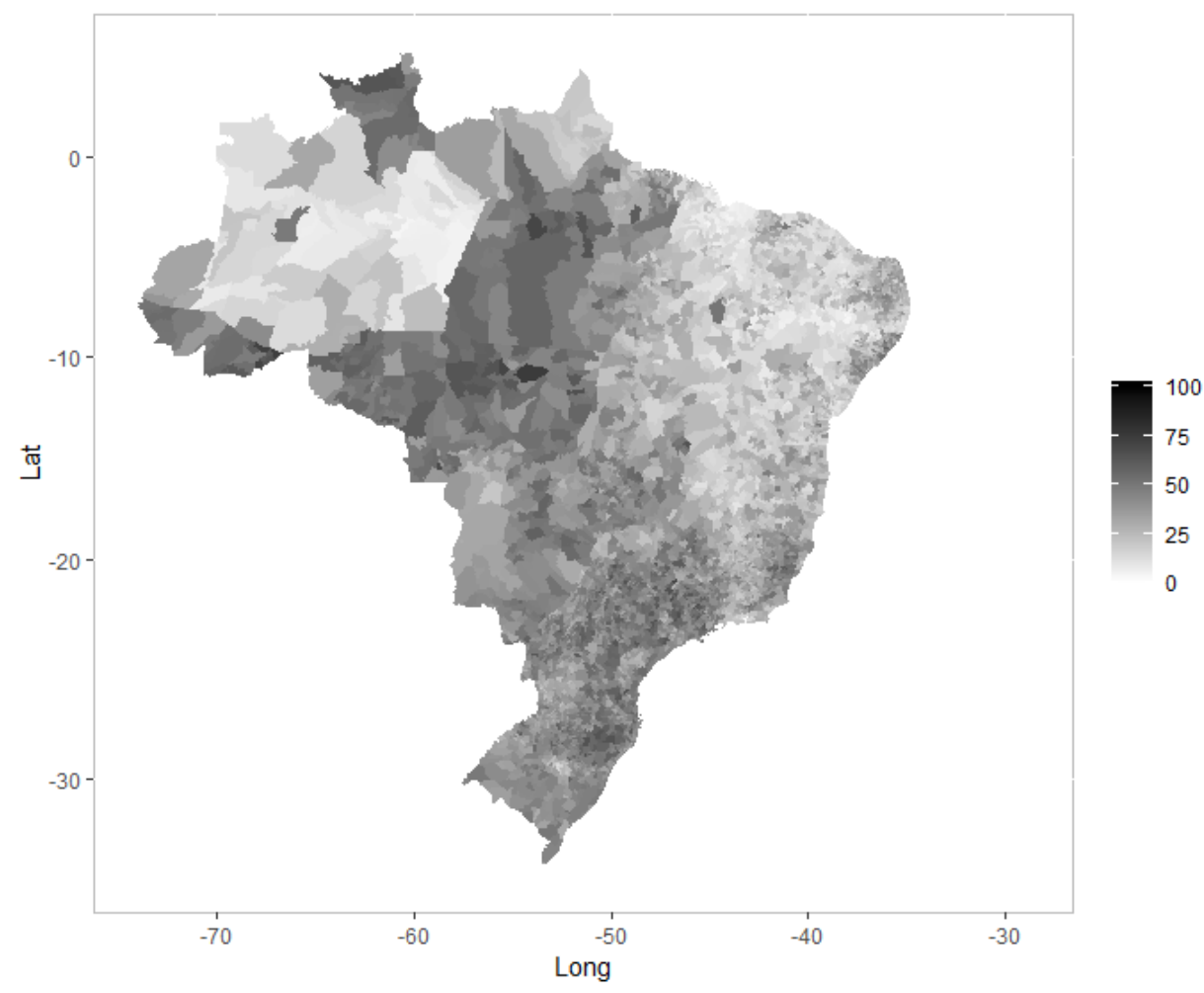

Nota: elaborado pelo autor a partir dos dados do Tribunal Superior Eleitoral (TSE). O mapa reporta o percentual de votos válidos do PSDB (segundo turno) em cada município brasileiro ( $N=5,565)$. 
Figura 37 - Distribuição espacial da votação do PSDB nas eleições presidenciais (2014)



Nota: elaborado pelo autor a partir dos dados do Tribunal Superior Eleitoral (TSE). O mapa reporta o percentual de votos válidos do PSDB (segundo turno) em cada município brasileiro ( $N=5,570)$. 
Figura 38 - Distribuição espacial da votação do PSL nas eleições presidenciais (2018)

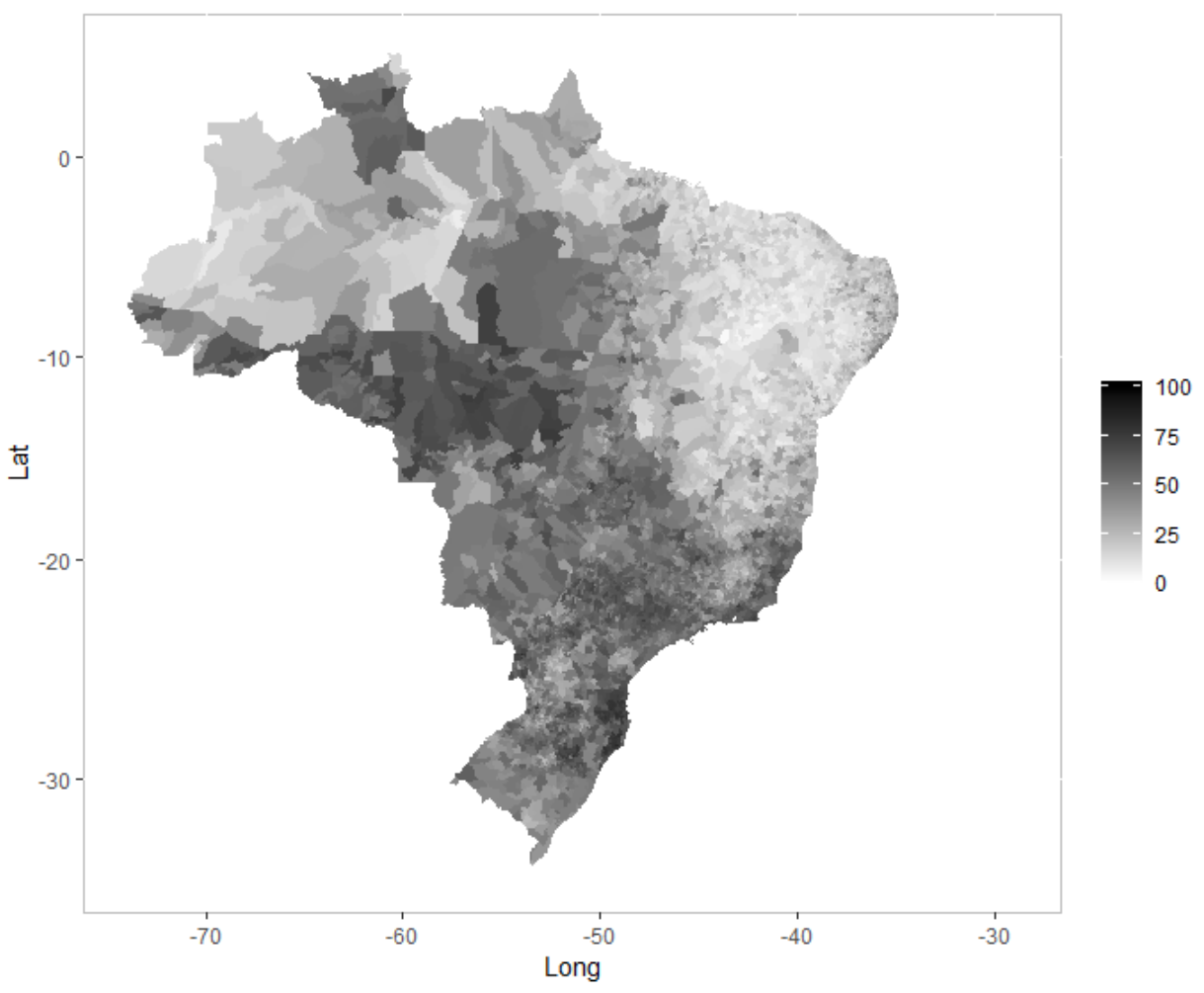

Nota: elaborado pelo autor a partir dos dados do Tribunal Superior Eleitoral (TSE). O mapa reporta o percentual de votos válidos do PSL (segundo turno) em cada município brasileiro ( $\mathrm{N}=5,570)$. 


\section{APÊNDICE C - Grandes religiões}

\section{cristãs no território brasileiro}

Figura 39 - Distribuição (\%) católica no território brasileiro (2010)

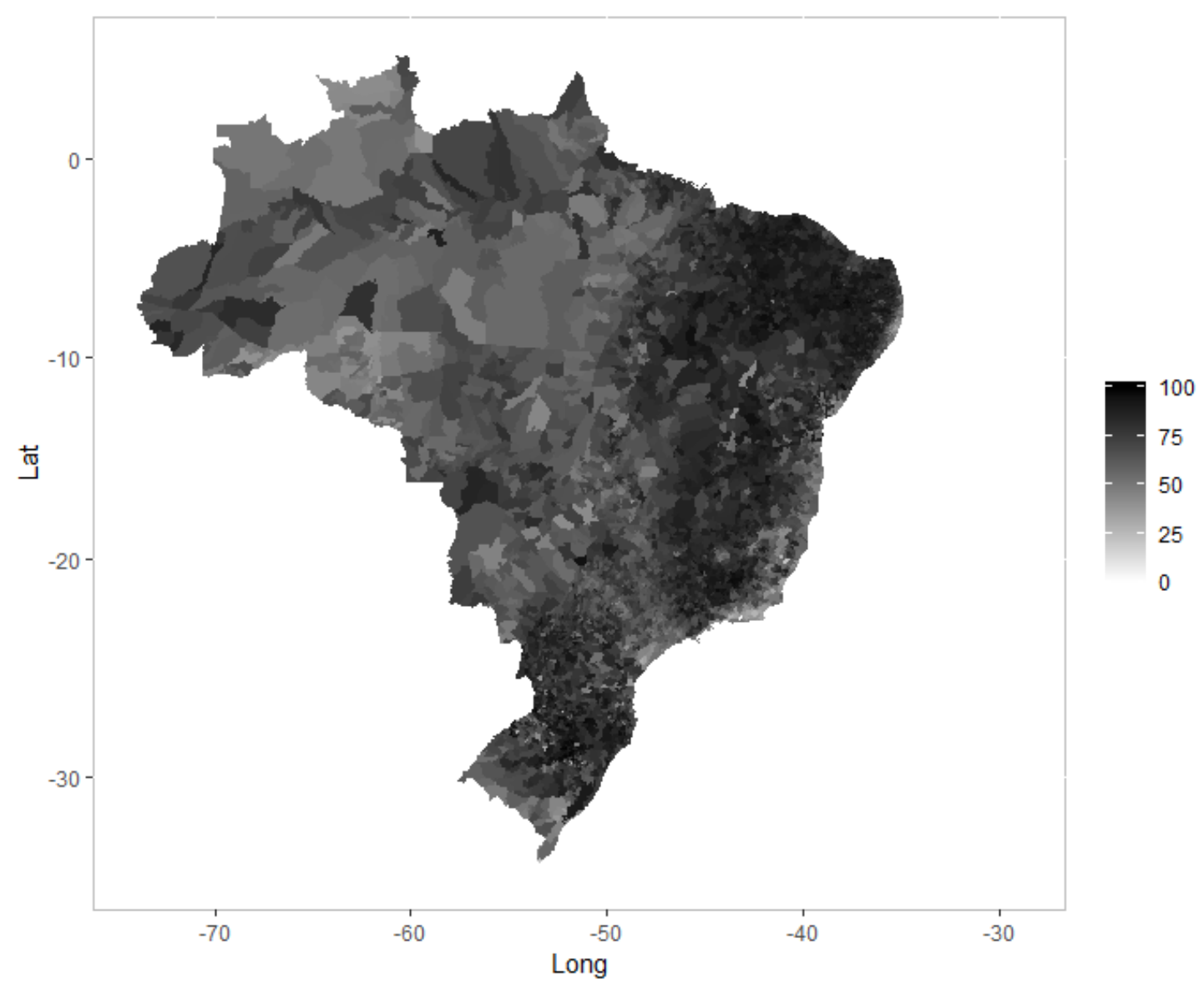

Nota: elaborado pelo autor a partir do censo de 2010 do Instituto Brasileiro de Geografia e Estatística (IBGE). O mapa reporta o percentual de católicos em cada município brasileiro $(\mathrm{N}=5,565)$. 
Figura 40 - Distribuição (\%) evangélica pentecostal no território brasileiro (2010)

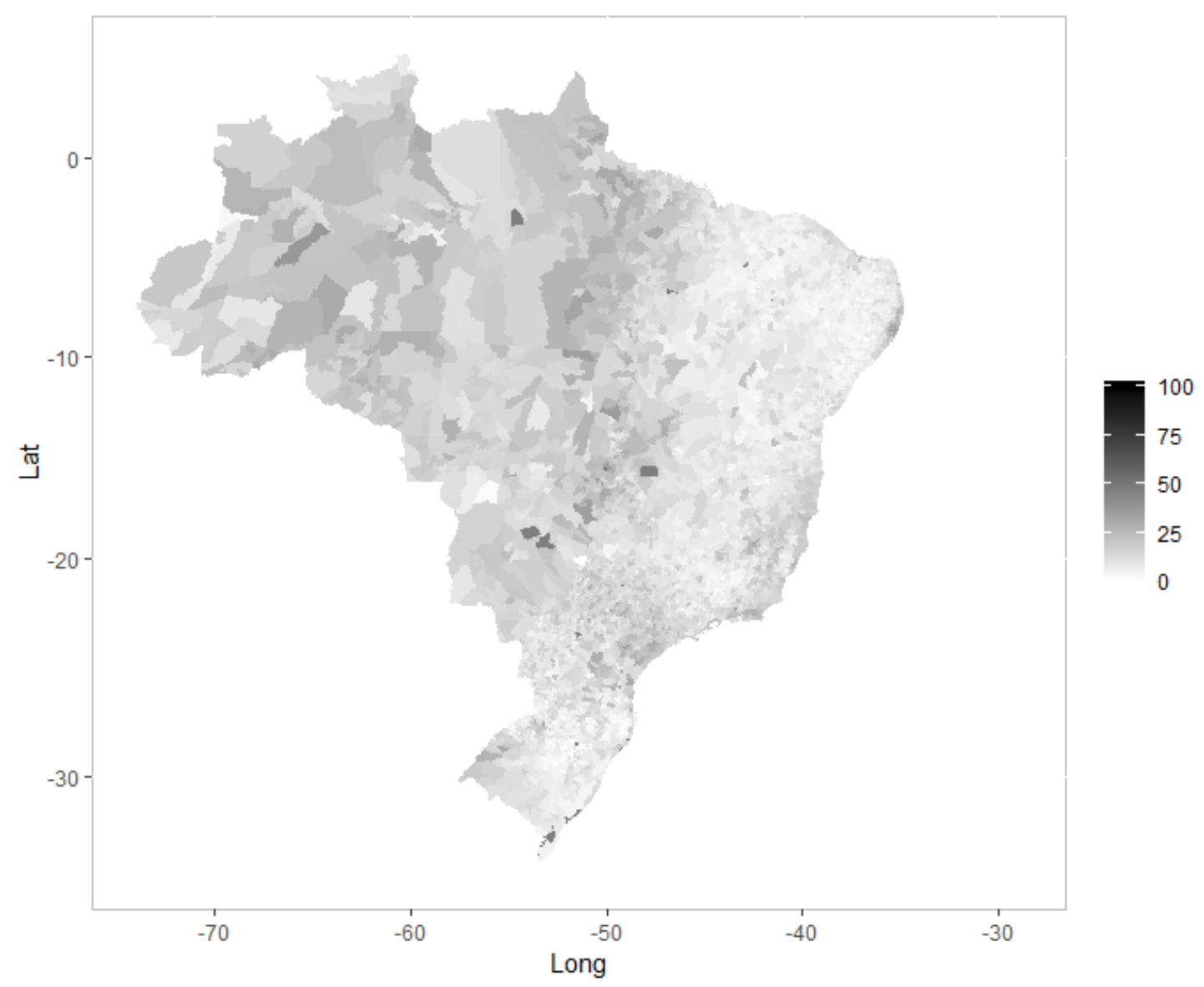

Nota: elaborado pelo autor a partir do censo de 2010 do Instituto Brasileiro de Geografia e Estatística (IBGE). O mapa reporta o percentual de evangélicos pentecostais em cada município brasileiro $(\mathrm{N}=$ $5,565)$. 
Figura 41 - Distribuição (\%) evangélica tradicional no território brasileiro (2010)

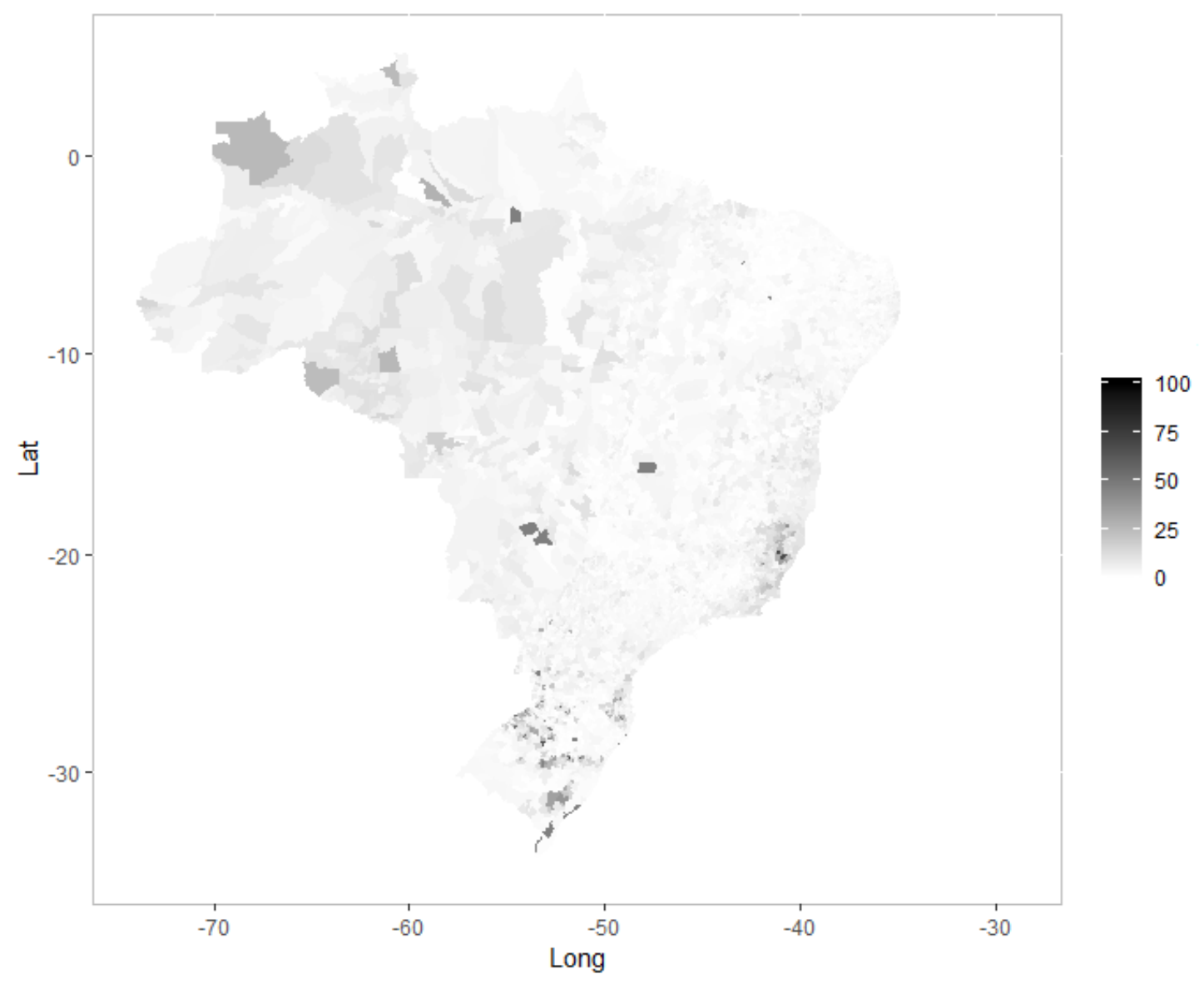

Nota: elaborado pelo autor a partir do censo de 2010 do Instituto Brasileiro de Geografia e Estatística (IBGE). O mapa reporta o percentual de evangélicos tradicionais em cada município brasileiro $(\mathrm{N}=5,565)$. 



\section{APÊNDICE D - Mapa de calor da}

\section{religião católica}

Figura 42 - Mapa de calor da distribuição da religião católica no Brasil



Nota: elaborado pelo autor a partir dos dados do Estudo do Instituto Brasileiro de Geografia e Estatística (IBGE) e do Tribunal Superior Eleitoral (TSE). A unidade de análise é o município ( $\mathrm{N}=5,565)$. Mapa de calor derivado da estatística $G e t i s-\operatorname{Ord}_{i}^{*}(d)$ calculada com o algoritmo proposto por Kondo (2016). Tons mais escuros de vermelho significam alta probabilidade ( $p$-value próximo de zero) de autocorrelação espacial, enquanto as áreas mais claras significam baixa probabilidade ( $p$-value próximo de 1) de autocorrelação espacial. 



\section{APÊNDICE E - Balanceamento das}

\section{covariáveis}

Figura 43 - Balanceamento da variável taxa de fertilidade (2000)



Nota: elaborado pelo autor a partir dos dados do Estudo do Instituto Brasileiro de Geografia e Estatística (IBGE) e do Tribunal Superior Eleitoral (TSE). A unidade de análise é o município $(\mathrm{N}=5,565)$ 
Figura 44 - Balanceamento da variável taxa de mortalidade (2000)



Nota: elaborado pelo autor a partir dos dados do Estudo do Instituto Brasileiro de Geografia e Estatística (IBGE) e do Tribunal Superior Eleitoral (TSE). A unidade de análise é o município $(\mathrm{N}=5,565)$ 
Figura 45 - Balanceamento da variável taxa de sobrevida aos 40 anos (2000)

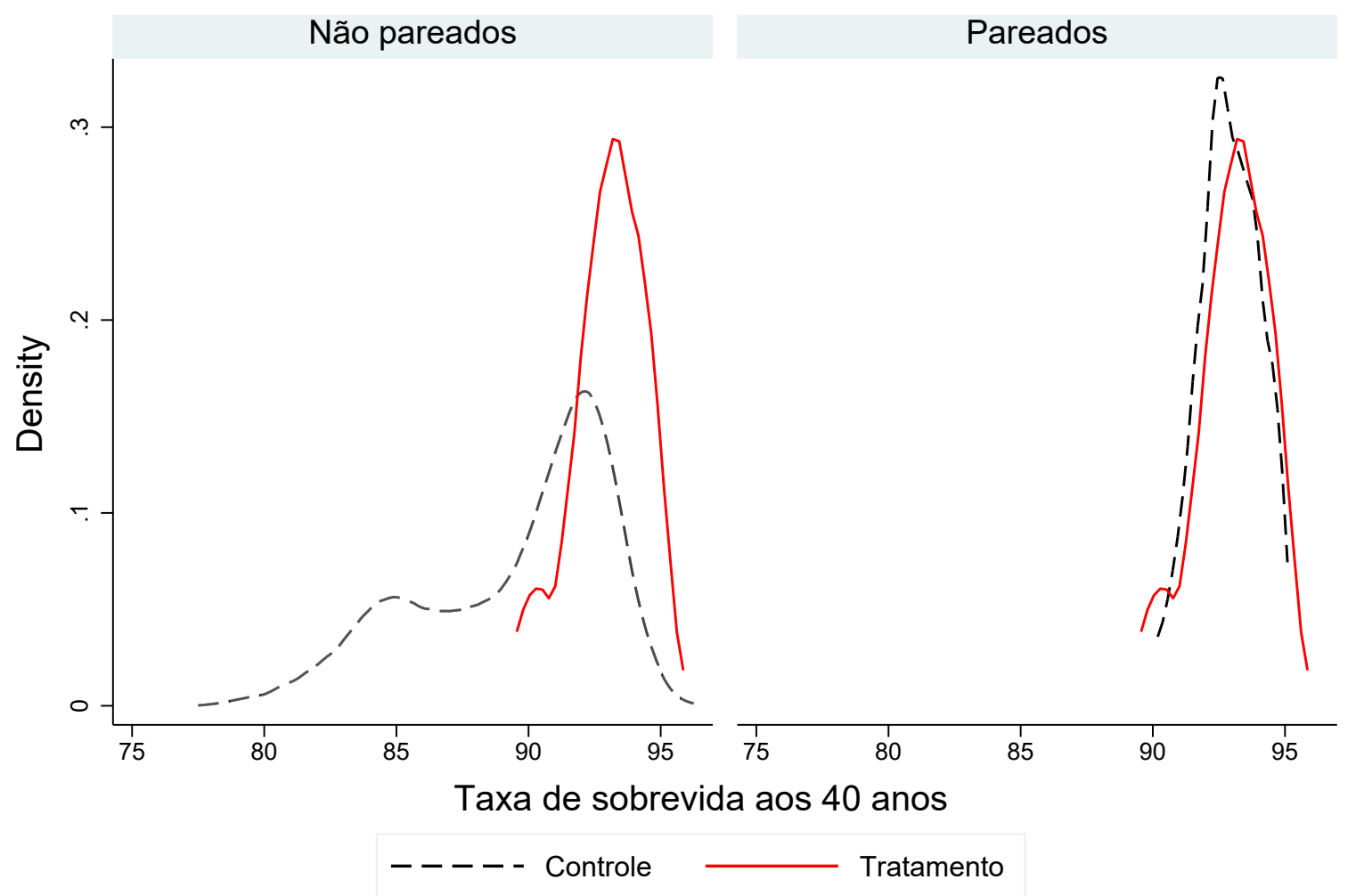

Nota: elaborado pelo autor a partir dos dados do Estudo do Instituto Brasileiro de Geografia e Estatística (IBGE) e do Tribunal Superior Eleitoral (TSE). A unidade de análise é o município $(\mathrm{N}=5,565)$ 
Figura 46 - Balanceamento da variável taxa de sobrevida aos 60 anos (2000)

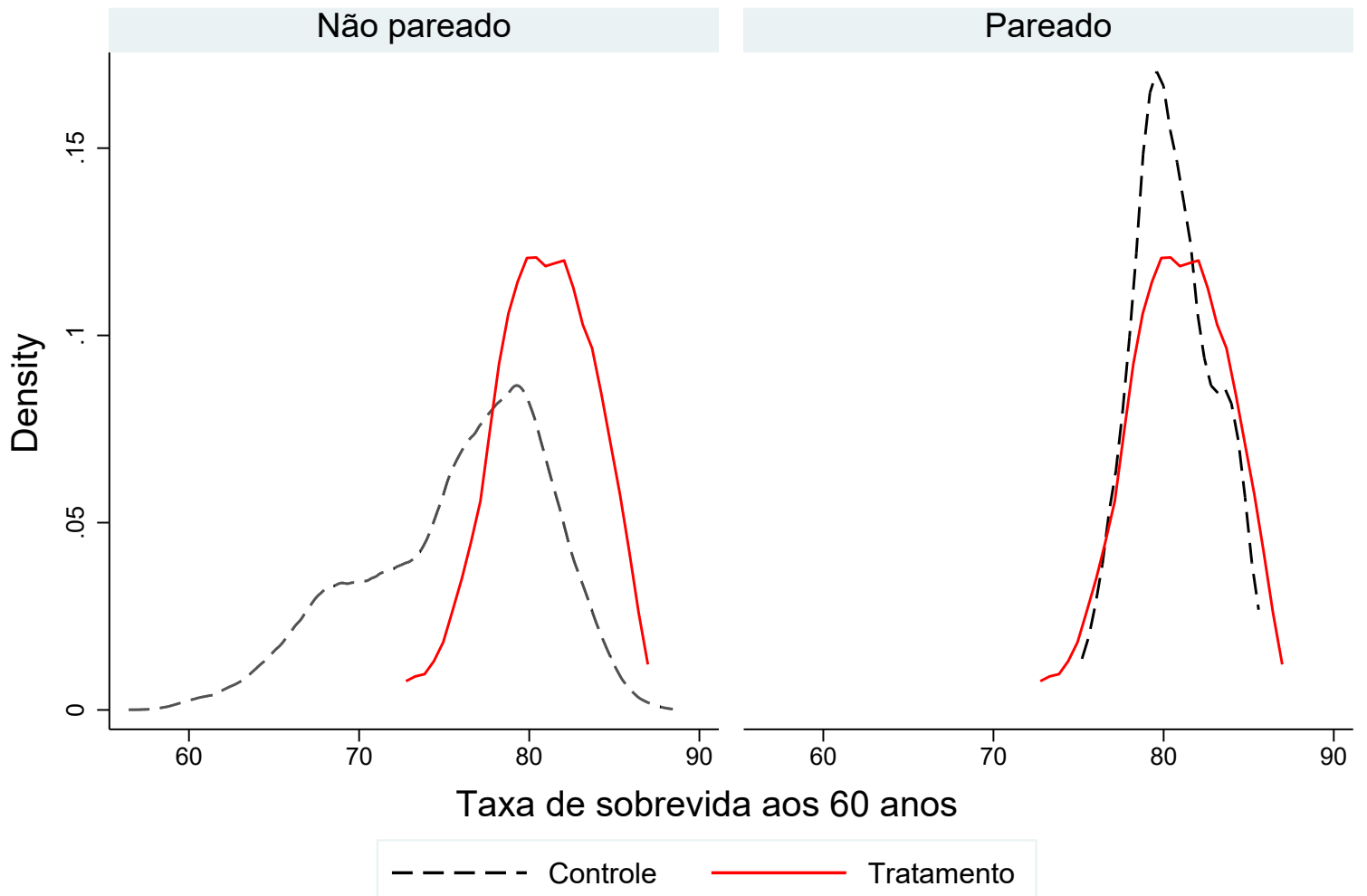

Nota: elaborado pelo autor a partir dos dados do Estudo do Instituto Brasileiro de Geografia e Estatística (IBGE) e do Tribunal Superior Eleitoral (TSE). A unidade de análise é o município $(\mathrm{N}=5,565)$ 
Figura 47 - Balanceamento da variável expectativa de anos de estudo (2000)

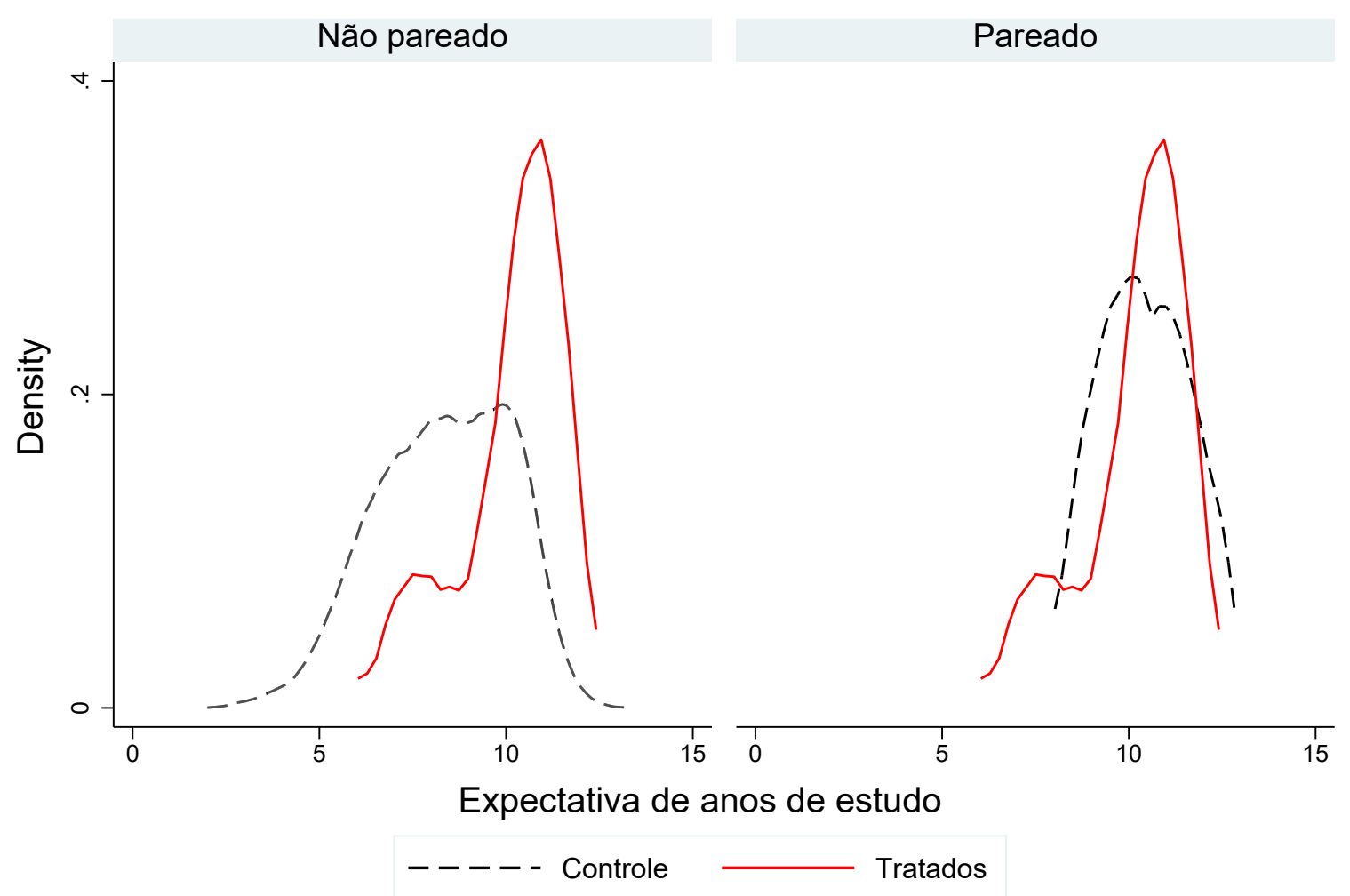

Nota: elaborado pelo autor a partir dos dados do Estudo do Instituto Brasileiro de Geografia e Estatística (IBGE) e do Tribunal Superior Eleitoral (TSE). A unidade de análise é o município $(\mathrm{N}=5,565)$ 
Figura 48 - Balanceamento da variável desigualdade de renda (Gini) (2000)

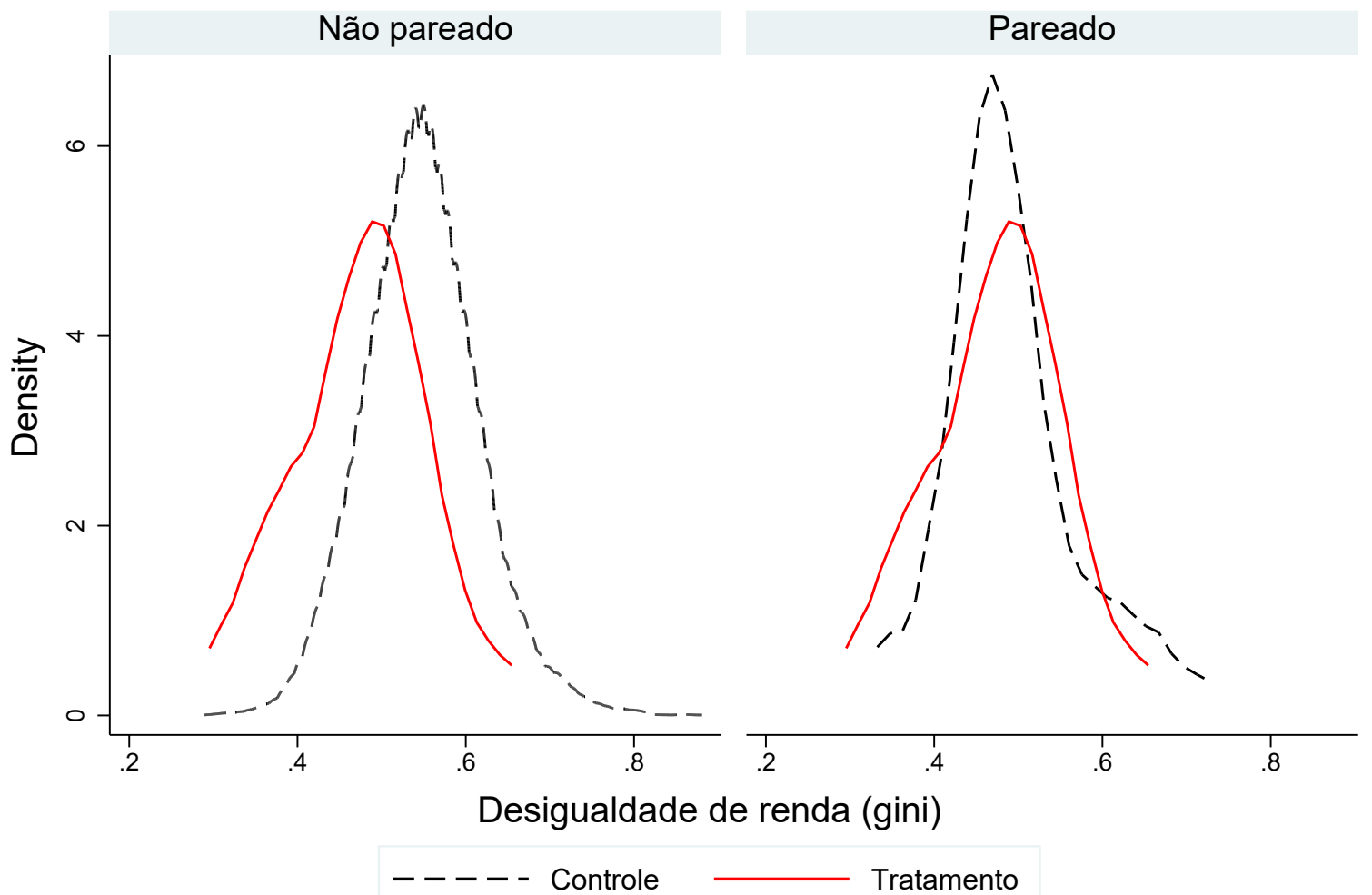

Nota: elaborado pelo autor a partir dos dados do Estudo do Instituto Brasileiro de Geografia e Estatística (IBGE) e do Tribunal Superior Eleitoral (TSE). A unidade de análise é o município $(\mathrm{N}=5,565)$ 
Figura 49 - Balanceamento da variável taxa de pobreza (2000)

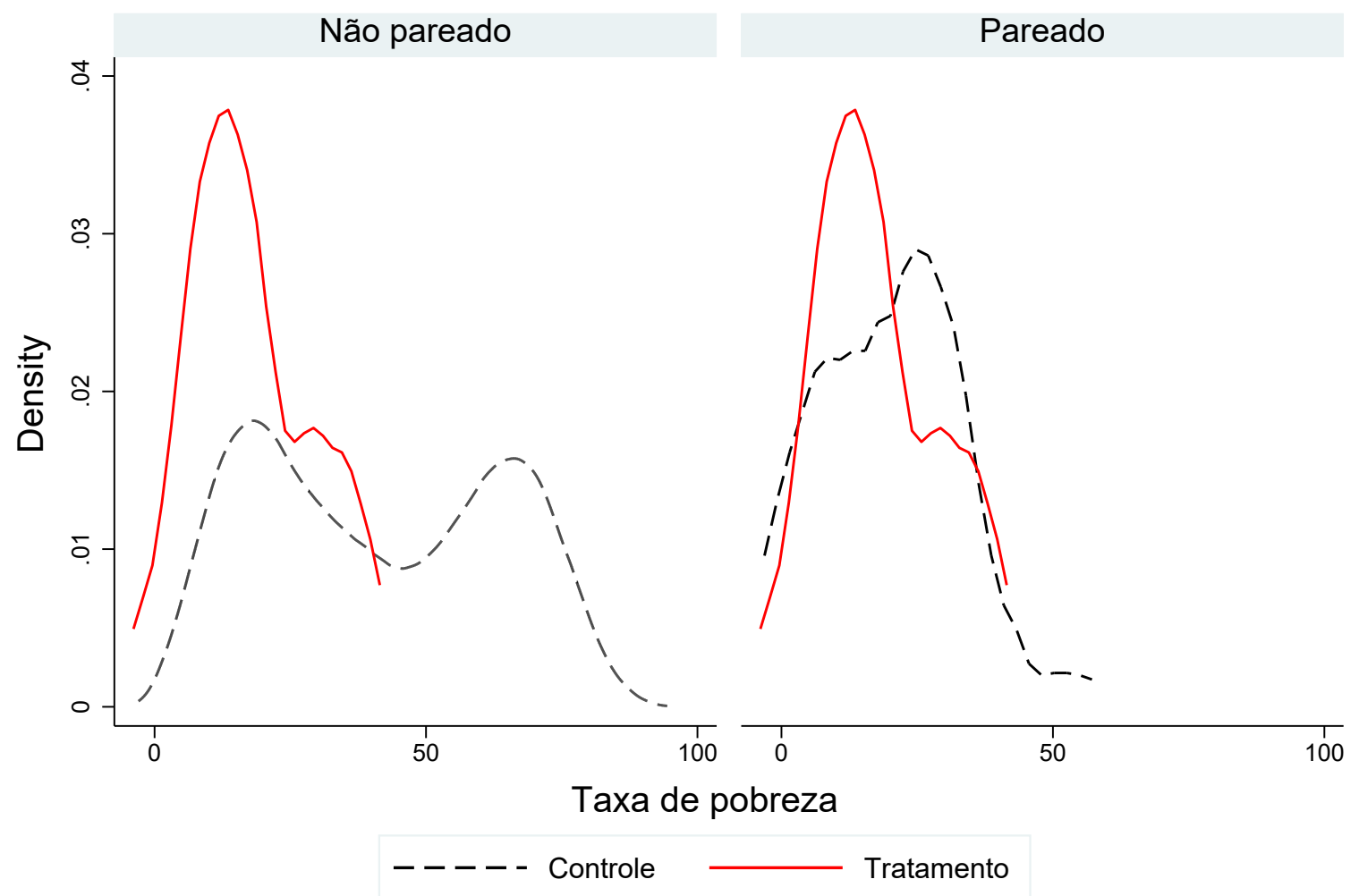

Nota: elaborado pelo autor a partir dos dados do Estudo do Instituto Brasileiro de Geografia e Estatística (IBGE) e do Tribunal Superior Eleitoral (TSE). A unidade de análise é o município $(\mathrm{N}=5,565)$ 
Figura 50 - Balanceamento da variável vulnerabilidade (2000)



Nota: elaborado pelo autor a partir dos dados do Estudo do Instituto Brasileiro de Geografia e Estatística (IBGE) e do Tribunal Superior Eleitoral (TSE). A unidade de análise é o município $(\mathrm{N}=5,565)$ 
Figura 51 - Balanceamento da variável renda per capita dos mais pobres (2000)



Nota: elaborado pelo autor a partir dos dados do Estudo do Instituto Brasileiro de Geografia e Estatística (IBGE) e do Tribunal Superior Eleitoral (TSE). A unidade de análise é o município $(\mathrm{N}=5,565)$ 
Figura 52 - Balanceamento da variável população no mercado de trabalho formal (2000)

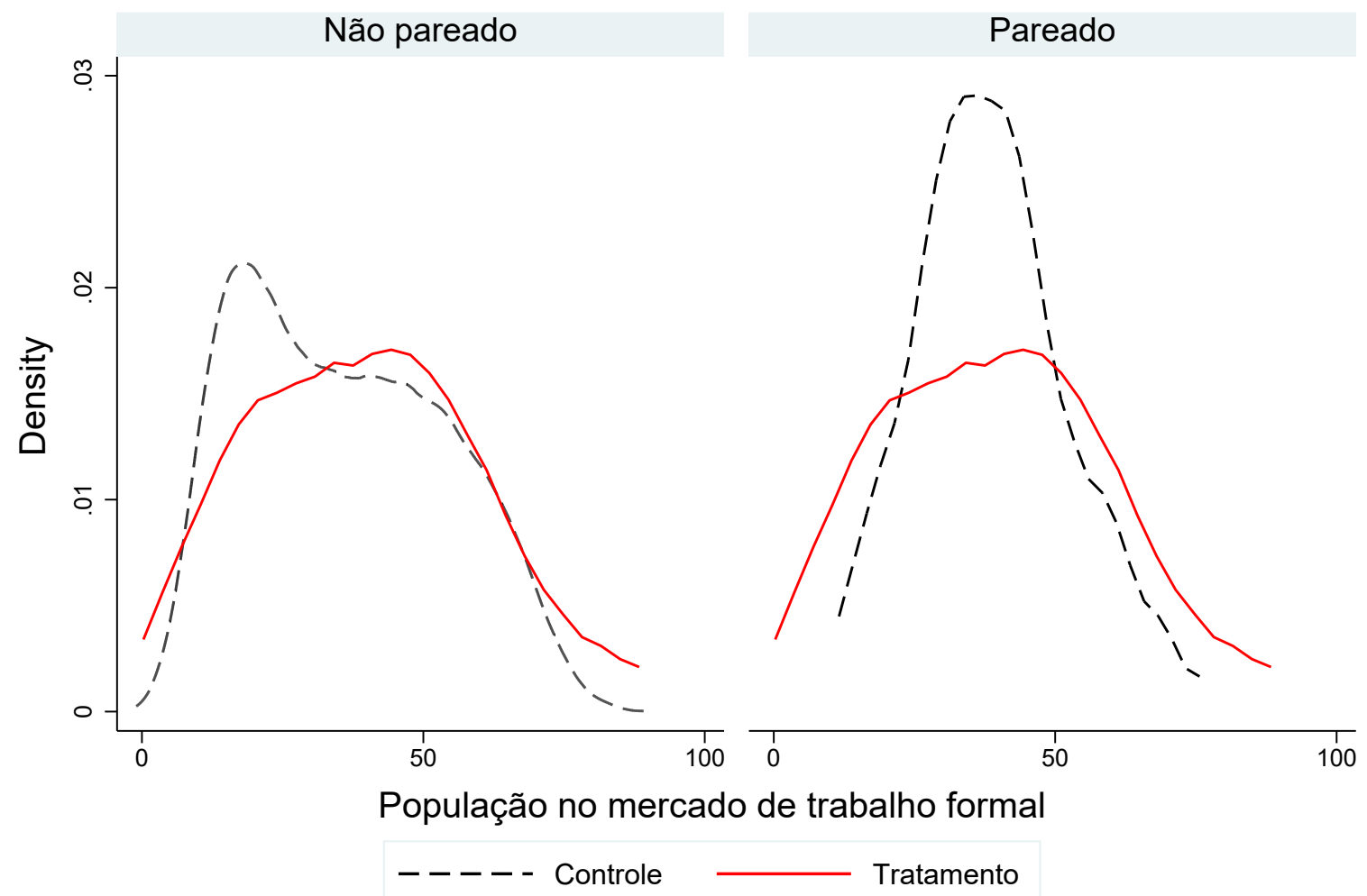

Nota: elaborado pelo autor a partir dos dados do Estudo do Instituto Brasileiro de Geografia e Estatística (IBGE) e do Tribunal Superior Eleitoral (TSE). A unidade de análise é o município $(\mathrm{N}=5,565)$ 
Figura 53 - Balanceamento da variável população economicamente ativa (2000)

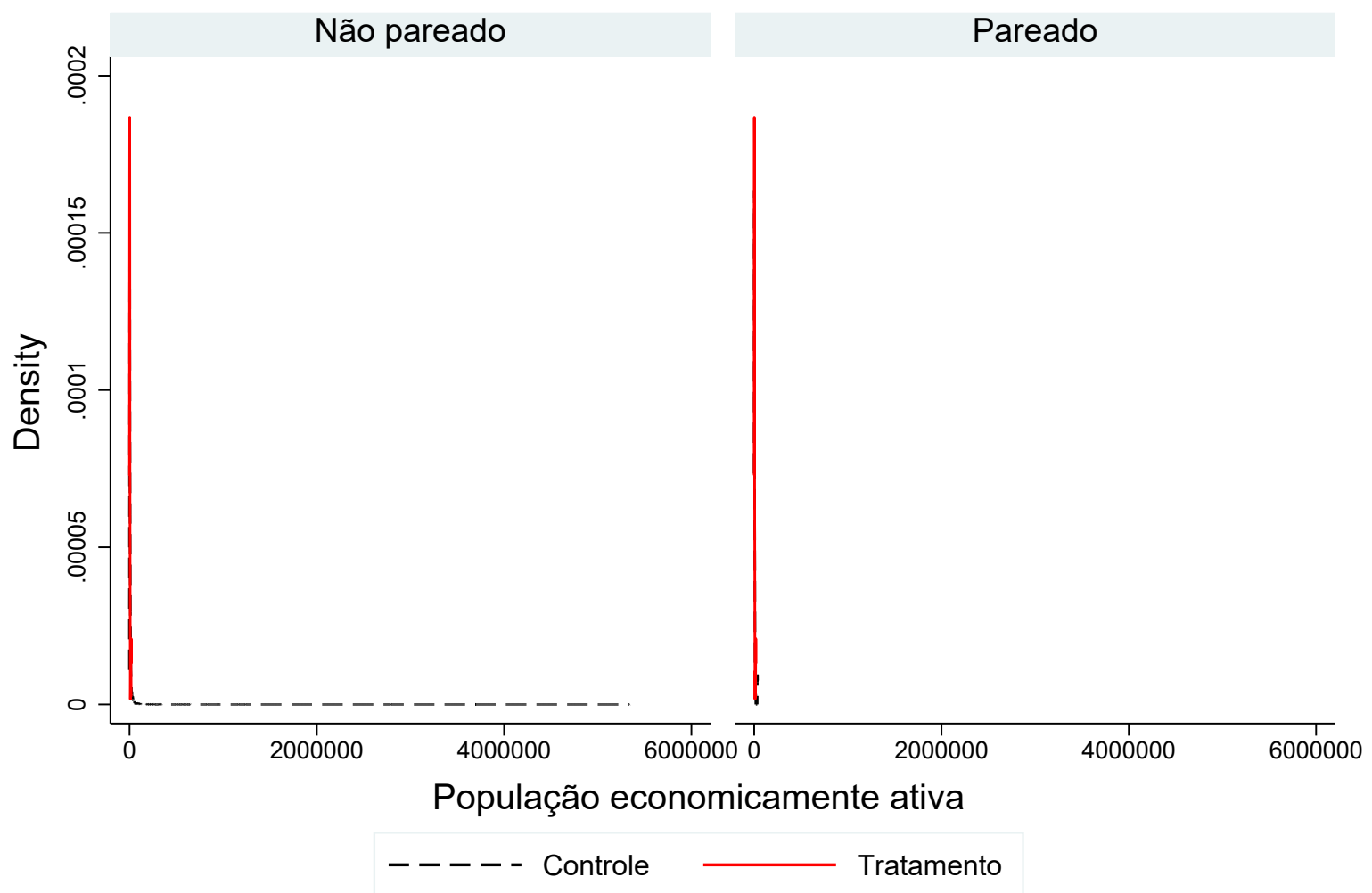

Nota: elaborado pelo autor a partir dos dados do Estudo do Instituto Brasileiro de Geografia e Estatística (IBGE) e do Tribunal Superior Eleitoral (TSE). A unidade de análise é o município $(\mathrm{N}=5,565)$ 
Figura 54 - Balanceamento da variável tamanho da população (2000)

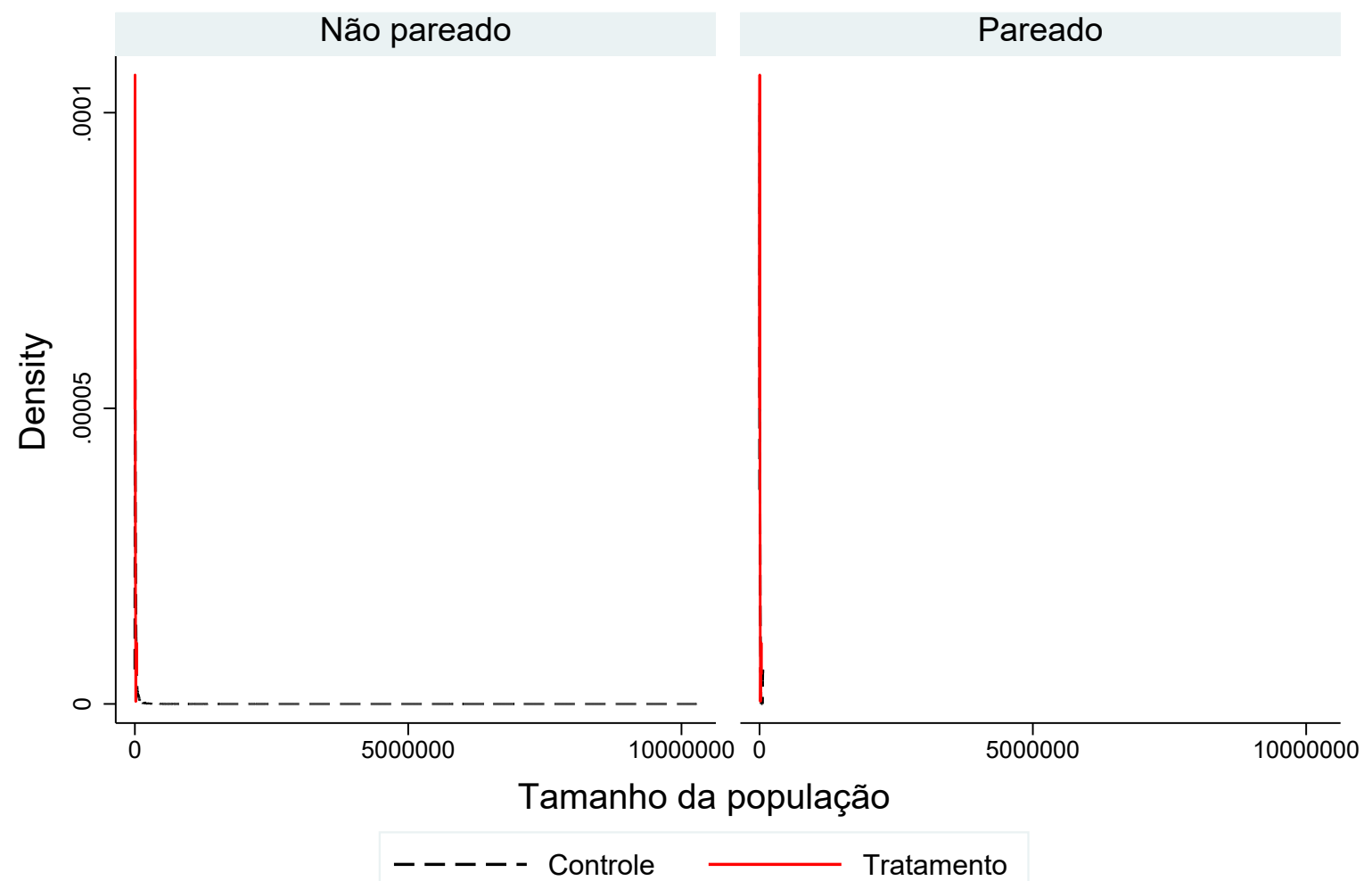

Nota: elaborado pelo autor a partir dos dados do Estudo do Instituto Brasileiro de Geografia e Estatística (IBGE) e do Tribunal Superior Eleitoral (TSE). A unidade de análise é o município $(\mathrm{N}=5,565)$ 


\section{APÊNDICE F - Municípios brasileiros}

\section{com maioria evangélica}

Tabela 6 - Lista dos municípios com transição religiosa completa em 2010

\begin{tabular}{|c|c|c|c|c|c|}
\hline Município & UF & População & $\%$ Pentecostais & \% Tradicionais & \% Católicos \\
\hline Alto Bela Vista & SC & 2005 & 1.24 & 48.5 & 46.8 \\
\hline Alto Caparaó & MG & 5238 & 8.28 & 47.2 & 28.9 \\
\hline Arabutã & SC & 4184 & .763 & 65.3 & 15.5 \\
\hline Armação dos Búzios & RJ & 27276 & 19.6 & 15.2 & 30.9 \\
\hline Arroio do Padre & RS & 2730 & 6.88 & 69.3 & 7.76 \\
\hline Braço do Trombudo & SC & 3371 & 7.95 & 37.3 & 44.4 \\
\hline Cajati & $\mathrm{SP}$ & 28207 & 29.5 & 9.59 & 29.8 \\
\hline Cardoso Moreira & RJ & 12439 & 12.6 & 22.6 & 32.1 \\
\hline Casimiro de Abreu & RJ & 35180 & 22.3 & 12.4 & 32.7 \\
\hline Colinas & RS & 2418 & 5.37 & 50.4 & 41.9 \\
\hline Condor & RS & 6539 & 16.1 & 27.8 & 41.5 \\
\hline Coronel Barros & RS & 2451 & 9.35 & 53.1 & 36.1 \\
\hline Cunha Porã & SC & 10566 & 4.71 & 44.1 & 45.8 \\
\hline Forquetinha & RS & 2479 & .685 & 50.0 & 39.3 \\
\hline Guaraíta & GO & 2376 & 52.1 & .294 & 37.0 \\
\hline Guaraqueçaba & PR & 7852 & 30.3 & 16.1 & 37.4 \\
\hline Itapemirim & ES & 30900 & 21.9 & 17.8 & 35.3 \\
\hline Itapuã do Oeste & RO & 8443 & 28.7 & 9.07 & 35.2 \\
\hline Jacupiranga & SP & 17161 & 24.1 & 11.5 & 33.7 \\
\hline Japeri & RJ & 93278 & 26.7 & 5.68 & 26.3 \\
\hline Lagoa dos Três Cantos & RS & 1598 & 1.12 & 47.1 & 47.6 \\
\hline Lajeado do Bugre & RS & 2487 & 38.5 & 3.17 & 37.9 \\
\hline Laranja da Terra & ES & 10792 & 2.74 & 68.7 & 25.7 \\
\hline Linha Nova & RS & 1624 & 2.58 & 67.3 & 27.1 \\
\hline Marataízes & ES & 34003 & 24.9 & 18.3 & 35.2 \\
\hline Nova Campina & SP & 8481 & 34.5 & 9.70 & 39.4 \\
\hline Nova Santa Rosa & PR & 7578 & 7.44 & 47.0 & 38.9 \\
\hline Novo Machado & RS & 3914 & 6.24 & 50.8 & 34.2 \\
\hline Novo Xingu & RS & 1755 & 6.94 & 44.4 & 47.5 \\
\hline Palestina de Goiás & GO & 3319 & 34.0 & 10.2 & 41.9 \\
\hline Panambi & RS & 37837 & 12.4 & 31.5 & 42.5 \\
\hline Paraíso do Sul & RS & 7325 & 2.20 & 47.6 & 46.6 \\
\hline Paty do Alferes & RJ & 26248 & 34.1 & 3.29 & 35.1 \\
\hline Pomerode & $\mathrm{SC}$ & 27548 & 7.66 & 41.1 & 35.8 \\
\hline Queimados & RJ & 137712 & 25.4 & 6.61 & 26.3 \\
\hline Quinze de Novembro & RS & 3648 & 2.38 & 65.9 & 30.5 \\
\hline Rancho Queimado & $\mathrm{SC}$ & 2717 & .509 & 51.8 & 44.0 \\
\hline Santa Maria de Jetibá & ES & 34121 & 6.54 & 69.0 & 20.9 \\
\hline São Pedro da Aldeia & RJ & 87646 & 23.2 & 12.1 & 32.2 \\
\hline São Pedro dos Crentes & MA & 4406 & 50.6 & .338 & 41.2 \\
\hline Senador Salgado Filho & RS & 2814 & 9.70 & 53.5 & 26.2 \\
\hline Seropédica & RJ & 77485 & 24.8 & 9.82 & 27.4 \\
\hline Silva Jardim & RJ & 21301 & 28.1 & 11.9 & 26.8 \\
\hline Sirinhaém & PE & 39858 & 30.2 & 3.44 & 33.2 \\
\hline Tanguá & RJ & 30495 & 21.0 & 10.2 & 30.6 \\
\hline Torre de Pedra & SP & 2233 & 26.0 & 16.5 & 38.0 \\
\hline Ubiretama & RS & 2296 & 4.18 & 46.2 & 45.9 \\
\hline Vila Pavão & ES & 8635 & 8.72 & 40.7 & 42.9 \\
\hline Westfália & RS & 2785 & 1.57 & 77.1 & 20.2 \\
\hline
\end{tabular}

Nota: elaborado pelo autor a partir do censo de 2010 do Instituto Brasileiro de Geografia e Estatística (IBGE). As colunas não somam $100 \%$ porque outros grupos religiosos e o grupo dos "sem religião"não são considerados. 



\section{APÊNDICE G - Estatísticas descritivas}

A tabela 7 informa as estatísticas descritivas das variáveis do censo (2000 e 2010)

utilizadas neste trabalho.

Tabela 7 - Descritivas das variáveis de nível municipal (2000 e 2010)

\begin{tabular}{lccccc}
\hline \hline Variável & Obs & Média & SD & Min & Max \\
\hline Censo 2000 & & & & & \\
Expectativa de vida & 5,565 & 68.41 & 3.964 & 57.46 & 77.24 \\
Taxa de natalidade & 5,565 & 2.870 & 0.736 & 1.560 & 7.790 \\
Taxa de mortalidade & 5,565 & 32.68 & 14.35 & 10.78 & 96.37 \\
Taxa de envelhecimento & 5,565 & 6.459 & 1.916 & 0.640 & 15.60 \\
Expectativa de anos de estudo & 5,565 & 8.338 & 1.797 & 2.290 & 13.02 \\
Gini & 5,565 & 0.547 & 0.0687 & 0.300 & 0.870 \\
Taxa de pobreza & 5,565 & 41.07 & 22.78 & 0.700 & 90.76 \\
Taxa de vunerabilidade & 5,565 & 63.91 & 20.71 & 5.170 & 99 \\
Renda per capita (pobres) & 5,565 & 120.5 & 31.87 & 36.38 & 227.1 \\
Formalização & 5,565 & 36.02 & 18.12 & 1.920 & 86.38 \\
Desocupação & 5,565 & 9.593 & 5.636 & 0 & 55.98 \\
PEA & 5,565 & 13724 & 91625 & 280 & $5.341 \mathrm{e}+06$ \\
População & 5,565 & 29802 & 181015 & 779 & $1.030 \mathrm{e}+07$ \\
IDHM & 5,565 & 0.523 & 0.104 & 0.208 & 0.820 \\
Urbanização & 5,565 & 0.585 & 0.237 & 0 & 1 \\
Católicos & 5,565 & 81.76 & 11.75 & 12.07 & 100 \\
Tradicionais & 5,565 & 3.295 & 5.988 & 0 & 80.37 \\
Pentecostais & 5,565 & 8.212 & 5.576 & 0 & 46.10 \\
Censo 2010 & & & & & \\
Expectativa de vida & 5,565 & 73.09 & 2.680 & 65.30 & 78.64 \\
Taxa de natalidade & 5,565 & 2.190 & 0.503 & 1.210 & 4.890 \\
Taxa de mortalidade & 5,565 & 19.25 & 7.136 & 8.490 & 46.80 \\
Taxa de envelhecimento & 5,565 & 8.398 & 2.423 & 1.460 & 20.42 \\
Expectativa de anos de estudo & 5,565 & 9.463 & 1.098 & 4.340 & 12.83 \\
Gini 10 & 5,565 & 0.494 & 0.0661 & 0.280 & 0.800 \\
Taxa de pobreza 10 & 5,565 & 23.21 & 17.92 & 0 & 78.59 \\
Taxa de vulnerabilidade 10 & 5,565 & 44.00 & 22.44 & 1.970 & 91.57 \\
Renda per capita (pobres) 10 & 5,565 & 146.0 & 30.26 & 41.53 & 217.1 \\
Formalização & 5,565 & 43.50 & 19.27 & 2.970 & 89.11 \\
Desocupação & 5,565 & 6.195 & 3.657 & 0 & 38.45 \\
PEA & 5,565 & 16611 & 105422 & 307 & $6.026 \mathrm{e}+06$ \\
População & 5,565 & 33593 & 198749 & 805 & $1.120 \mathrm{e}+07$ \\
IDHM & 5,565 & 0.659 & 0.0720 & 0.418 & 0.862 \\
Urbanização & 5,565 & 0.638 & 0.220 & 0.0400 & 1 \\
Católicos & 5,565 & 75.35 & 13.50 & 7.766 & 99.19 \\
Tradicionais & 5,565 & 3.561 & 5.461 & 0 & 77.12 \\
Pentecostais & 5,565 & 10.98 & 6.481 & 0 & 52.10 \\
\hline \hline & & & & & \\
\hline
\end{tabular}

Nota: elaborado pelo autor a partir dos dados do Instituto Brasileiro de Geografia e Estatística (IBGE). 
A tabela 8 informa as estatísticas descritivas da proporção de votos válidos do PT nas eleições presidenciais de 2002, 2006, 2010, 2014 e 2018. A tabela 8 também reporta as estatísticas descritivas do número de beneficiários do PBF em setembro de cada ano eleitoral (2006-2018).

Tabela 8 - Votação do PT (2002-2018) e alocação do PBF nos municípios brasileiros (2006-2018)

\begin{tabular}{lccccc}
\hline \hline Variável & Obs & Média & SD & Min & Max \\
\hline Votação do PT (2002) & 5,562 & 42.42 & 12.05 & 5.776 & 79.79 \\
Votação do PT (2006) & 5,565 & 51.62 & 17.85 & 11.41 & 93.37 \\
Votação do PT (2010) & 5,565 & 55.32 & 15.82 & 15.84 & 94.84 \\
Votação do PT (2014) & 5,565 & 52.67 & 18.53 & 10.34 & 92.75 \\
Votação do PT (2018) & 5,565 & 41.23 & 21.38 & 3.633 & 93.24 \\
Número de domicílios PBF (2006) & 5,565 & 1966 & 5434 & 0 & 213592 \\
Número de domićlios PBF (2010) & 5,565 & 2282 & 6655 & 1 & 195868 \\
Número de domicílios PBF (2014) & 5,565 & 2498 & 8201 & 3 & 341262 \\
Número de domicílios PBF (2018) & 5,565 & 2498 & 8201 & 3 & 341262 \\
PBF como proporção da população (2006) & 5,565 & 9.262 & 4.744 & 0 & 29.51 \\
PBF como proporção da população (2010) & 5,565 & 9.579 & 5.004 & 0.0378 & 24.11 \\
PBF como proporção da população (2014) & 5,565 & 10.38 & 6.142 & 0.103 & 24.61 \\
PBF como proporção da população (2018) & 5,565 & 10.38 & 6.142 & 0.103 & 24.61 \\
\hline \hline
\end{tabular}

Nota: elaborado pelo autor a partir dos dados do Instituto Brasileiro de Geografia e Estatística (IBGE) e do Tribunal Superior Eleitoral (TSE). 
A tabela 9 informa as estatísticas descritivas das variáveis do ESEB (2010) utilizadas neste trabalho.

Tabela 9 - Descritivas das variáveis do ESEB (2010)

\begin{tabular}{lccccc}
\hline \hline Variável & Obs & Média & SD & Min & Max \\
\hline Idade & 1,999 & 41.07 & 15.66 & 17 & 93 \\
Gênero & 2,000 & 1.517 & 0.500 & 1 & 2 \\
Escolaridade & 2,000 & 5.038 & 2.276 & 1 & 10 \\
Renda & 1,970 & 2.838 & 2.355 & 1 & 8 \\
Raça & 1,993 & 2.035 & 0.969 & 1 & 5 \\
Católico & 1,997 & 0.618 & 0.486 & 0 & 1 \\
Pentecostal & 1,997 & 0.150 & 0.357 & 0 & 1 \\
Tradicional & 1,997 & 0.0686 & 0.253 & 0 & 1 \\
Beneficiário PBF & 2,000 & 0.163 & 0.369 & 0 & 1 \\
Beneficiário LPT & 2,000 & 0.0300 & 0.171 & 0 & 1 \\
Beneficiário MCMV & 2,000 & 0.0275 & 0.164 & 0 & 1 \\
Beneficiário Prouni & 2,000 & 0.0160 & 0.126 & 0 & 1 \\
Preferência partidária & 2,000 & 0.171 & 0.377 & 0 & 1 \\
Economia (país) & 2,000 & 0.0730 & 0.260 & 0 & 1 \\
Economia (família) & 2,000 & 0.0585 & 0.235 & 0 & 1 \\
Melhora da renda & 2,000 & 0.498 & 0.500 & 0 & 1 \\
Avaliação governo & 2,000 & 0.498 & 0.500 & 0 & 1 \\
Avaliação Lula & 2,000 & 0.931 & 0.253 & 0 & 1 \\
Votou PT (2010) & 1,862 & 0.483 & 0.500 & 0 & 1 \\
\hline \hline
\end{tabular}

Nota: elaborado pelo autor a partir dos dados do Estudo Eleitoral Brasileiro (ESEB, 2010). 
A tabela 10 informa as estatísticas descritivas das variáveis do ESEB (2014) utilizadas neste trabalho.

Tabela 10 - Descritivas das variáveis do ESEB (2014)

\begin{tabular}{lccccc}
\hline \hline Variável & Obs & Média & SD & Min & Max \\
\hline Idade & 3,136 & 41.61 & 15.82 & 16 & 89 \\
Gênero & 3,136 & 1.524 & 0.499 & 1 & 2 \\
Escolaridade & 3,136 & 4.539 & 2.264 & 0 & 9 \\
Renda & 3,070 & 3.410 & 1.332 & 1 & 7 \\
Raça & 3,113 & 2.343 & 0.734 & 1 & 5 \\
Pentecostal & 3,136 & 0.181 & 0.385 & 0 & 1 \\
Tradicional & 3,136 & 0.0373 & 0.190 & 0 & 1 \\
Católico & 3,136 & 0.614 & 0.487 & 0 & 1 \\
Ocupação & 3,136 & 0.0316 & 0.175 & 0 & 1 \\
Pobre & 3,070 & 0.268 & 0.443 & 0 & 1 \\
Economia (país) & 3,136 & 0.702 & 0.458 & 0 & 1 \\
Beneficiário PBF & 3,136 & 0.272 & 0.445 & 0 & 1 \\
Avaliação governo & 3,136 & 0.428 & 0.495 & 0 & 1 \\
Preferência taxação & 3,136 & 0.520 & 0.500 & 0 & 1 \\
Preferência redistribuição & 3,136 & 0.803 & 0.398 & 0 & 1 \\
Freq. igreja & 3,136 & 0.388 & 0.487 & 0 & 1 \\
Jornal impresso & 3,136 & 0.284 & 0.451 & 0 & 1 \\
Jornal nacional & 3,136 & 0.777 & 0.416 & 0 & 1 \\
Jornal local & 3,136 & 0.717 & 0.450 & 0 & 1 \\
Rádio & 3,136 & 0.456 & 0.498 & 0 & 1 \\
Votou PT (2010) & 3,136 & 0.493 & 0.500 & 0 & 1 \\
Votou PT (2014) & 3,136 & 0.445 & 0.499 & 0 & 1 \\
\hline \hline
\end{tabular}

Nota: elaborado pelo autor a partir dos dados do Estudo Eleitoral Brasileiro (ESEB, 2014). 
A tabela 11 informa as estatísticas descritivas das variáveis do Latinobarômetro (2015) utilizadas neste trabalho.

Tabela 11 - Descritivas das variáveis do Latinobarômetro (2015)

\begin{tabular}{lccccc}
\hline \hline Variável & Obs & Média & SD & Min & Max \\
\hline Idade & 1,250 & 40.52 & 16.30 & 16 & 92 \\
Gênero & 1,250 & 1.506 & 0.500 & 1 & 2 \\
Escolaridade & 1,250 & 10.23 & 4.305 & 1 & 15 \\
Raça & 1,250 & 4.915 & 1.900 & 1 & 7 \\
Católico & 1,250 & 0.578 & 0.494 & 0 & 1 \\
Pentecostal & 1,250 & 0.207 & 0.405 & 0 & 1 \\
Tradicional & 1,250 & 0.0384 & 0.192 & 0 & 1 \\
Religioso praticante & 1,250 & 0.432 & 0.496 & 0 & 1 \\
Maconha & 1,250 & 0.190 & 0.393 & 0 & 1 \\
União homoafetiva & 1,250 & 0.402 & 0.491 & 0 & 1 \\
\hline \hline
\end{tabular}

Nota: elaborado pelo autor a partir dos dados do Latinobarômetro (2015). 
A tabela 12 informa as estatísticas descritivas das variáveis do LAPOP (2008) utilizadas neste trabalho.

Tabela 12 - Descritivas das variáveis do LAPOP (2008)

\begin{tabular}{lccccc}
\hline \hline Variável & Obs & Média & SD & Min & Max \\
\hline Idade & 1,489 & 41.43 & 16.96 & 18 & 94 \\
Gênero & 1,497 & 1.537 & 0.499 & 1 & 2 \\
Escolaridade & 1,480 & 1.583 & 0.738 & 0 & 3 \\
Raça & 1,478 & 1.863 & 1.214 & 1 & 7 \\
Renda & 1,432 & 3.785 & 1.837 & 1 & 11 \\
Urbano & 1,497 & 0.812 & 0.391 & 0 & 1 \\
Pentecostal & 1,484 & 0.115 & 0.319 & 0 & 1 \\
Tradicional & 1,484 & 0.0802 & 0.272 & 0 & 1 \\
Católico & 1,484 & 0.695 & 0.460 & 0 & 1 \\
Beneficiário PBF & 1,486 & 0.157 & 0.364 & 0 & 1 \\
Avaliação governo & 1,479 & 0.510 & 0.500 & 0 & 1 \\
Economia (país) & 1,466 & 0.218 & 0.413 & 0 & 1 \\
Economia (família) & 1,482 & 0.270 & 0.444 & 0 & 1 \\
Pref. taxação & 1,389 & 0.0922 & 0.289 & 0 & 1 \\
Pref. redistribuição & 1,408 & 0.707 & 0.455 & 0 & 1 \\
Religiosidade & 1,393 & 0.875 & 1.676 & 0 & 5 \\
Votou PT (2006) & 1,169 & 0.756 & 0.430 & 0 & 1 \\
\hline \hline
\end{tabular}

Nota: elaborado pelo autor a partir dos dados do LAPOP (2008). 
A tabela 13 informa as estatísticas descritivas das variáveis do LAPOP (2014) utilizadas neste trabalho.

Tabela 13 - Descritivas das variáveis do LAPOP (2014)

\begin{tabular}{lccccc}
\hline Variável & Obs & Média & SD. & Min & Max \\
\hline \hline Idade & 1,571 & 49.39 & 17.44 & 18 & 99 \\
Gênero & 1,571 & 0.330 & 0.470 & 0 & 1 \\
Escolaridade & 1,565 & 2.020 & 0.677 & 0 & 3 \\
Renda & 1,156 & 8.533 & 4.645 & 0 & 16 \\
Raça & 1,547 & 1.676 & 0.873 & 1 & 7 \\
Urbano & 1,571 & 0.867 & 0.340 & 0 & 1 \\
Pentecostal & 1,457 & 0.134 & 0.341 & 0 & 1 \\
Tradicional & 1,457 & 0.114 & 0.318 & 0 & 1 \\
Católico & 1,457 & 0.705 & 0.456 & 0 & 1 \\
Beneficiário CS & 1,558 & 0.0558 & 0.230 & 0 & 1 \\
Economia (país) & 1,542 & 0.197 & 0.398 & 0 & 1 \\
Economia (família) & 1,557 & 0.185 & 0.388 & 0 & 1 \\
Ocupação & 1,569 & 0.0357 & 0.186 & 0 & 1 \\
Religiosidade & 1,557 & 0.389 & 0.488 & 0 & 1 \\
Pref. redistribuição & 1,513 & 0.562 & 0.496 & 0 & 1 \\
Pref. taxação & 1,490 & 0.242 & 0.429 & 0 & 1 \\
Percep. desigualdade & 1,515 & 0.818 & 0.386 & 0 & 1 \\
Aborto & 1,435 & 0.657 & 0.475 & 0 & 1 \\
Votou PS (2013) & 843 & 0.660 & 0.474 & 0 & 1 \\
\hline \hline
\end{tabular}

Nota: elaborado pelo autor a partir dos dados do LAPOP (2014). 
A tabela 14 informa as estatísticas descritivas das variáveis do LAPOP (2017) utilizadas neste trabalho.

Tabela 14 - Descritivas das variáveis do LAPOP (2017)

\begin{tabular}{lccccc}
\hline \hline Variável & Obs & Média & SD. & Min & Max \\
\hline Gênero & 1,532 & 0.496 & 0.500 & 0 & 1 \\
Raça & 1,513 & 3.324 & 1.850 & 1 & 7 \\
Escolaridade & 1,098 & 2.057 & 1.982 & 0 & 8 \\
Renda & 1,444 & 6.521 & 4.658 & 0 & 16 \\
Pentecostal & 1,506 & 0.218 & 0.413 & 0 & 1 \\
Tradicional & 1,506 & 0.105 & 0.307 & 0 & 1 \\
Católico & 1,506 & 0.515 & 0.500 & 0 & 1 \\
Religiosidade & 1,529 & 0.806 & 0.395 & 0 & 1 \\
Região & 1,532 & 3.147 & 1.332 & 1 & 5 \\
Simpatia PT & 1,494 & 0.105 & 0.307 & 0 & 1 \\
\hline \hline
\end{tabular}

Nota: elaborado pelo autor a partir dos dados do LAPOP (2017). 
A tabela 15 informa as estatísticas descritivas das variáveis do Datafolha (2018) utilizadas neste trabalho.

Tabela 15 - Descritivas das variáveis do Datafolha (2018)

\begin{tabular}{lccccc}
\hline \hline Variável & Obs & Média & SD. & Min & Max \\
\hline Sexo & 3,235 & .4738 & .4993 & 0 & 1 \\
Idade & 3,235 & 3.078 & 1.337 & 1 & 5 \\
Escolaridade & 3,235 & 4.317 & 1.959 & 1 & 8 \\
Renda & 3,235 & 2.178 & 1.286 & 1 & 7 \\
Cor & 3,235 & 2.311 & 1.316 & 1 & 6 \\
Católicos & 3,235 & .5505 & .4975 & 0 & 1 \\
Pentecostais & 3,235 & .1567 & .3635 & 0 & 1 \\
Tradicionais & 3,235 & .1582 & .36504 & 0 & 1 \\
Ocupação & 3,235 & .0754 & .2641 & 0 & 1 \\
Pref.Partidária (PT) & 3,235 & .2142 & .4103 & 0 & 1 \\
Região & 3,235 & 2.412 & 1.371 & 1 & 5 \\
Porte do município & 3,235 & 3.136 & 1.641 & 1 & 5 \\
\hline \hline
\end{tabular}

Nota: elaborado pelo autor a partir dos dados do Datafolha (2018). 
A tabela 16 informa as estatísticas descritivas das variáveis dos dados do Two-City Brazilian Panel Study Dataset (BAKER; AMES; RENNO, 2006) utilizadas neste trabalho.

Tabela 16 - Descritivas das variáveis dos dados em painel (2002-2004)

\begin{tabular}{lccccc}
\hline \hline Variável & Obs & Média & SD. & Min & Max \\
\hline Honestidade é mais importante & 6800 & 0.748 & 0.434 & 0 & 1 \\
Acha o Lula honesto & 9030 & 0.604 & 0.489 & 0 & 1 \\
convertido & 9087 & 0.00814 & 0.0899 & 0 & 1 \\
Raça & 4524 & 0.626 & 0.484 & 0 & 1 \\
Idade & 9087 & 2.968 & 1.025 & 1 & 4 \\
Educação & 6763 & 8.172 & 3.726 & 0 & 15 \\
Percep. Economia (país) & 9053 & 0.138 & 0.345 & 0 & 1 \\
Percep. Economia (indivíduo) & 9051 & 0.208 & 0.406 & 0 & 1 \\
Desemprego & 6731 & 0.438 & 0.496 & 0 & 1 \\
Freq. Igreja & 4510 & 0.361 & 0.480 & 0 & 1 \\
Nível de politização & 9050 & 0.491 & 0.500 & 0 & 1 \\
Nível de sociabilidade & 4519 & 0.319 & 0.466 & 0 & 1 \\
Pref. Partido & 8955 & 0.380 & 0.485 & 0 & 1 \\
\hline \hline
\end{tabular}

Nota: elaborado pelo autor a partir dos dados da pesquisa Two-City Brazilian Panel Study Dataset (BAKER; AMES; RENNO, 2006). 


\section{APÊNDICE H - Tabelas de regressão}

Tabela 17 - Relação entre desigualdade de renda e voto no PT nas eleições presidenciais (2006-2018)

\begin{tabular}{|c|c|c|c|c|}
\hline & $\begin{array}{c}(1) \\
\text { PT (2006) }\end{array}$ & $\begin{array}{c}(2) \\
\text { PT }(2010)\end{array}$ & $\begin{array}{c}(3) \\
\text { PT (2014) }\end{array}$ & $\begin{array}{c}(4) \\
\text { PT (2018) }\end{array}$ \\
\hline Gini & $\begin{array}{l}-15.91^{* * *} \\
(-3.64)\end{array}$ & $\begin{array}{l}-26.23^{* * *} \\
(-6.08)\end{array}$ & $\begin{array}{l}-13.24^{* *} \\
(-3.22)\end{array}$ & $\begin{array}{l}-14.07^{* * *} \\
(-3.51)\end{array}$ \\
\hline Analfabetismo & $\begin{array}{c}0.475^{* * *} \\
(12.92)\end{array}$ & $\begin{array}{l}0.323^{* * *} \\
(9.66)\end{array}$ & $\begin{array}{l}0.244^{* * *} \\
(8.34)\end{array}$ & $\begin{array}{l}0.331^{* * *} \\
(9.93)\end{array}$ \\
\hline Pobreza & $\begin{array}{c}0.471^{* * *} \\
(11.99)\end{array}$ & $\begin{array}{l}0.421^{* * *} \\
(11.49)\end{array}$ & $\begin{array}{l}0.515^{* * *} \\
(14.28)\end{array}$ & $\begin{array}{c}0.576^{* * *} \\
(16.16)\end{array}$ \\
\hline Renda per capita & $\begin{array}{l}-0.0118^{* * *} \\
(-5.60)\end{array}$ & $\begin{array}{l}0.00351 \\
(1.79)\end{array}$ & $\begin{array}{l}-0.00146 \\
(-0.77)\end{array}$ & $\begin{array}{l}0.00765^{* * *} \\
(4.95)\end{array}$ \\
\hline Formalização & $\begin{array}{l}-0.0112 \\
(-0.67)\end{array}$ & $\begin{array}{l}-0.127^{* * *} \\
(-7.79)\end{array}$ & $\begin{array}{l}-0.201^{* * *} \\
(-11.83)\end{array}$ & $\begin{array}{l}-0.0910^{* * *} \\
(-5.75)\end{array}$ \\
\hline Desocupação & $\begin{array}{l}0.328^{* * *} \\
(5.27)\end{array}$ & $\begin{array}{l}-0.145^{*} \\
(-2.50)\end{array}$ & $\begin{array}{l}-0.233^{* * *} \\
(-4.19)\end{array}$ & $\begin{array}{l}0.239^{* * *} \\
(4.02)\end{array}$ \\
\hline IDHM & $\begin{array}{l}86.17^{* * *} \\
(10.61)\end{array}$ & $\begin{array}{l}10.15 \\
(1.29)\end{array}$ & $\begin{array}{l}20.95^{* *} \\
(2.88)\end{array}$ & $\begin{array}{l}-50.41^{* * *} \\
(-6.44)\end{array}$ \\
\hline Região & $\begin{array}{l}-1.976^{* * *} \\
(-10.01)\end{array}$ & $\begin{array}{l}0.853^{* * *} \\
(4.51)\end{array}$ & $\begin{array}{r}0.281 \\
(1.51)\end{array}$ & $\begin{array}{l}0.965^{* * *} \\
(5.54)\end{array}$ \\
\hline PBF (2006) & $\begin{array}{l}0.000273^{* * *} \\
(3.55)\end{array}$ & & & \\
\hline PBF (2010) & & $\begin{array}{l}0.0000721^{* * *} \\
(4.12)\end{array}$ & & \\
\hline PBF (2014) & & & $\begin{array}{l}0.0000367^{*} \\
(2.00)\end{array}$ & \\
\hline PBF (2018) & & & & $\begin{array}{l}-0.00000122 \\
(-0.08)\end{array}$ \\
\hline Constante & $\begin{array}{l}-16.80^{* *} \\
(-2.72)\end{array}$ & $\begin{array}{l}39.50^{* * *} \\
(6.70)\end{array}$ & $\begin{array}{l}28.51^{* * *} \\
(5.23)\end{array}$ & $\begin{array}{l}46.16^{* * *} \\
(7.93)\end{array}$ \\
\hline Observações & 5562 & 5562 & 5562 & 5562 \\
\hline
\end{tabular}

Estatística $t$ entre parênteses

${ }^{\ddagger} p<0.10^{*} p<0.05,{ }^{* *} p<0.01,{ }^{* * *} p<0.001$

Nota: elaborado pelo autor a partir dos dados do Instituto Brasileiro de Geografia e Estatística (IBGE) e do Tribunal Superior Eleitoral (TSE). A variável dependente é a proporção de votos válidos do PT nas eleições presidenciais (2006-2018). 
Tabela 18 - Relação entre pobreza e voto no PT nas eleições presidenciais por filiação religiosa (2014)

\begin{tabular}{|c|c|c|c|c|}
\hline & $\begin{array}{c}(1) \\
\text { Todos }\end{array}$ & $\begin{array}{c}(2) \\
\text { Pentecostais }\end{array}$ & $\begin{array}{c}(3) \\
\text { Tradicionais }\end{array}$ & $\begin{array}{c}(4) \\
\text { Católicos }\end{array}$ \\
\hline Pobre & $\begin{array}{l}-0.0708^{\ddagger} \\
(-1.95)\end{array}$ & $\begin{array}{l}-0.266^{* *} \\
(-2.99)\end{array}$ & $\begin{array}{r}0.196 \\
(1.30)\end{array}$ & $\begin{array}{l}-0.00120 \\
(-0.03)\end{array}$ \\
\hline Idade & $\begin{array}{l}-0.00226^{*} \\
(-1.97)\end{array}$ & $\begin{array}{l}-0.000431 \\
(-0.14)\end{array}$ & $\begin{array}{l}-0.00217 \\
(-0.46)\end{array}$ & $\begin{array}{l}-0.00228 \\
(-1.57)\end{array}$ \\
\hline Gênero & $\begin{array}{l}0.0239 \\
(0.76)\end{array}$ & $\begin{array}{l}0.0247 \\
(0.31)\end{array}$ & $\begin{array}{l}0.401^{* *} \\
(2.64)\end{array}$ & $\begin{array}{l}0.00596 \\
(0.15)\end{array}$ \\
\hline Escolaridade & $\begin{array}{l}-0.0308^{* * *} \\
(-3.82)\end{array}$ & $\begin{array}{l}-0.0285 \\
(-1.30)\end{array}$ & $\begin{array}{l}-0.0386 \\
(-0.93)\end{array}$ & $\begin{array}{l}-0.0249^{*} \\
(-2.44)\end{array}$ \\
\hline Raça & $\begin{array}{l}-0.0656^{* *} \\
(-2.95)\end{array}$ & $\begin{array}{l}-0.0656 \\
(-1.26)\end{array}$ & $\begin{array}{l}-0.172 \\
(-1.44)\end{array}$ & $\begin{array}{l}-0.0913^{* *} \\
(-3.17)\end{array}$ \\
\hline Ocupação & $\begin{array}{l}-0.00245 \\
(-0.03)\end{array}$ & $\begin{array}{l}-0.0266 \\
(-0.15)\end{array}$ & $\begin{array}{l}1.340^{*} \\
(2.55)\end{array}$ & $\begin{array}{l}-0.0545 \\
(-0.41)\end{array}$ \\
\hline Percep. Economia & $\begin{array}{l}0.195^{* * *} \\
(5.36)\end{array}$ & $\begin{array}{l}0.162^{*} \\
(1.98)\end{array}$ & $\begin{array}{r}0.245 \\
(1.34)\end{array}$ & $\begin{array}{l}0.175^{\text {*** }} \\
(3.61)\end{array}$ \\
\hline Avaliação Gov. & $\begin{array}{c}0.846^{* * *} \\
(24.22)\end{array}$ & $\begin{array}{l}0.748^{* * *} \\
(8.81)\end{array}$ & $\begin{array}{l}1.061^{* * *} \\
(5.95)\end{array}$ & $\begin{array}{c}0.870^{* * *} \\
(19.84)\end{array}$ \\
\hline Pref. Partido & $\begin{array}{l}-0.0341 \\
(-0.36)\end{array}$ & $\begin{array}{l}-0.0422 \\
(-0.13)\end{array}$ & $\begin{array}{l}-0.253 \\
(-1.01)\end{array}$ & $\begin{array}{l}-0.0783 \\
(-0.68)\end{array}$ \\
\hline Pref. Redistribuição & $\begin{array}{l}0.0564 \\
(1.41)\end{array}$ & $\begin{array}{l}0.0953 \\
(1.00)\end{array}$ & $\begin{array}{l}0.0678 \\
(0.38)\end{array}$ & $\begin{array}{l}-0.00548 \\
(-0.11)\end{array}$ \\
\hline Pref. Taxação & $\begin{array}{l}-0.0474 \\
(-1.50)\end{array}$ & $\begin{array}{c}0.114 \\
(1.48)\end{array}$ & $\begin{array}{l}-0.182 \\
(-1.21)\end{array}$ & $\begin{array}{l}-0.0692 \\
(-1.74)\end{array}$ \\
\hline Região & $\begin{array}{l}-0.101^{* * *} \\
(-5.35)\end{array}$ & $\begin{array}{l}-0.0251 \\
(-0.57)\end{array}$ & $\begin{array}{l}-0.0915 \\
(-0.99)\end{array}$ & $\begin{array}{l}-0.126^{* * *} \\
(-5.20)\end{array}$ \\
\hline Constante & $\begin{array}{l}1.087^{* * *} \\
(9.05)\end{array}$ & $\begin{array}{l}0.671^{*} \\
(2.25)\end{array}$ & $\begin{array}{r}0.549 \\
(0.94)\end{array}$ & $\begin{array}{l}1.310^{* * *} \\
(8.67)\end{array}$ \\
\hline Observações & 3049 & 552 & 115 & 1871 \\
\hline
\end{tabular}

Estatística $t$ entre parênteses

${ }^{\ddagger} p<0.10^{*} p<0.05,{ }^{* *} p<0.01,{ }^{* * *} p<0.001$

Nota: elaborado pelo autor a partir dos dados do Estudo Eleitoral Brasileiro (ESEB, 2014). A variável dependente assume o valor 1 se o indivíduo votou no PT nas eleições presidenciais de 2014 e 0, caso contrário. 
Tabela 19 - Consumo de informação (mídias tradicionais) por filiação religiosa (2014)

\begin{tabular}{|c|c|c|c|c|c|c|}
\hline & $\begin{array}{c}(1) \\
\text { Impresso/dig }\end{array}$ & $\begin{array}{c}(2) \\
\text { Impresso/dig }\end{array}$ & $\begin{array}{c}(3) \\
\text { Impresso/dig }\end{array}$ & $\begin{array}{c}(4) \\
\text { Nacional }\end{array}$ & $\begin{array}{c}(5) \\
\text { Nacional }\end{array}$ & $\begin{array}{c}(6) \\
\text { Nacional }\end{array}$ \\
\hline Pentecostais & $\begin{array}{l}-0.0913 \\
(-0.81)\end{array}$ & & & $\begin{array}{l}-0.210^{\ddagger} \\
(-1.83)\end{array}$ & & \\
\hline Tradicionais & & $\begin{array}{l}0.0322 \\
(0.15)\end{array}$ & & & $\begin{array}{l}0.964^{* *} \\
(3.04)\end{array}$ & \\
\hline Católicos & & & $\begin{array}{l}0.247^{* *} \\
(2.83)\end{array}$ & & & $\begin{array}{l}0.154^{\ddagger} \\
(1.69)\end{array}$ \\
\hline Idade & $\begin{array}{l}0.0193^{* * *} \\
(6.40)\end{array}$ & $\begin{array}{l}0.0195^{* * *} \\
(6.53)\end{array}$ & $\begin{array}{l}0.0187^{* * *} \\
(6.16)\end{array}$ & $\begin{array}{l}0.0172^{* * *} \\
(4.95)\end{array}$ & $\begin{array}{l}0.0179^{* * *} \\
(5.16)\end{array}$ & $\begin{array}{l}0.0171^{* * *} \\
(4.96)\end{array}$ \\
\hline Gênero & $\begin{array}{l}-0.531^{* * *} \\
(-6.36)\end{array}$ & $\begin{array}{l}-0.535^{* * *} \\
(-6.41)\end{array}$ & $\begin{array}{l}-0.531^{* * *} \\
(-6.35)\end{array}$ & $\begin{array}{l}-0.189^{*} \\
(-2.10)\end{array}$ & $\begin{array}{l}-0.201^{*} \\
(-2.24)\end{array}$ & $\begin{array}{l}-0.193^{*} \\
(-2.15)\end{array}$ \\
\hline Escolaridade & $\begin{array}{l}0.108^{* * *} \\
(5.38)\end{array}$ & $\begin{array}{l}0.109^{* * *} \\
(5.45)\end{array}$ & $\begin{array}{l}0.111^{* * *} \\
(5.55)\end{array}$ & $\begin{array}{l}0.116^{* * *} \\
(5.12)\end{array}$ & $\begin{array}{l}0.116^{* * *} \\
(5.13)\end{array}$ & $\begin{array}{l}0.119^{* * *} \\
(5.26)\end{array}$ \\
\hline Renda & $\begin{array}{l}0.0406 \\
(1.28)\end{array}$ & $\begin{array}{l}0.0404 \\
(1.27)\end{array}$ & $\begin{array}{l}0.0397 \\
(1.24)\end{array}$ & $\begin{array}{l}0.0104 \\
(0.30)\end{array}$ & $\begin{array}{l}0.0104 \\
(0.30)\end{array}$ & $\begin{array}{l}0.00892 \\
(0.26)\end{array}$ \\
\hline Raça & $\begin{array}{l}0.0459 \\
(0.82)\end{array}$ & $\begin{array}{l}0.0493 \\
(0.88)\end{array}$ & $\begin{array}{l}0.0362 \\
(0.64)\end{array}$ & $\begin{array}{l}-0.0686 \\
(-1.11)\end{array}$ & $\begin{array}{l}-0.0582 \\
(-0.94)\end{array}$ & $\begin{array}{l}-0.0688 \\
(-1.12)\end{array}$ \\
\hline Ocupação & $\begin{array}{l}-0.356 \\
(-1.27)\end{array}$ & $\begin{array}{l}-0.359 \\
(-1.28)\end{array}$ & $\begin{array}{l}-0.346 \\
(-1.24)\end{array}$ & $\begin{array}{r}0.188 \\
(0.72)\end{array}$ & $\begin{array}{r}0.190 \\
(0.73)\end{array}$ & $\begin{array}{r}0.189 \\
(0.73)\end{array}$ \\
\hline Região & $\begin{array}{l}0.166^{* * *} \\
(3.59)\end{array}$ & $\begin{array}{l}0.165^{* * *} \\
(3.57)\end{array}$ & $\begin{array}{l}0.174^{* * *} \\
(3.73)\end{array}$ & $\begin{array}{l}-0.0110 \\
(-0.21)\end{array}$ & $\begin{array}{l}-0.0136 \\
(-0.26)\end{array}$ & $\begin{array}{l}-0.00751 \\
(-0.14)\end{array}$ \\
\hline Religiosidade & $\begin{array}{r}0.161 \\
(1.85)\end{array}$ & $\begin{array}{r}0.145 \\
(1.70)\end{array}$ & $\begin{array}{c}0.173^{*} \\
(2.02)\end{array}$ & $\begin{array}{c}0.222^{*} \\
(2.36)\end{array}$ & $\begin{array}{c}0.153 \\
(1.67)\end{array}$ & $\begin{array}{c}0.204^{*} \\
(2.21)\end{array}$ \\
\hline Constante & $\begin{array}{l}-2.241^{* * *} \\
(-7.31)\end{array}$ & $\begin{array}{l}-2.265^{* * *} \\
(-7.41)\end{array}$ & $\begin{array}{l}-2.403^{* * *} \\
(-7.75)\end{array}$ & $\begin{array}{c}0.409 \\
(1.22)\end{array}$ & $\begin{array}{c}0.348 \\
(1.04)\end{array}$ & $\begin{array}{c}0.276 \\
(0.81)\end{array}$ \\
\hline Observações & 3049 & 3049 & 3049 & 3049 & 3049 & 3049 \\
\hline
\end{tabular}

Estatística $t$ entre parênteses.

${ }^{\ddagger} p<0.10^{*} p<0.05,{ }^{* *} p<0.01,{ }^{* * *} p<0.001$

Nota: elaborado pelo autor a partir dos dados do Estudo Eleitoral Brasileiro (ESEB, 2014). Nos modelos de 1 a 3, a variável dependente assume valor 1 se o indivíduo tem o hábito de ler jornal impresso ou digital. Nos modelos de 4 a 6, a variável dependente assume valor 1 se o indivíduo tem o hábito de assistir ao noticiário nacional e 0 , caso contrário. 
Tabela 20 - Consumo de informação (mídias tradicionais) por filiação religiosa (2014) continuação

\begin{tabular}{|c|c|c|c|c|c|c|}
\hline & $\begin{array}{c}(1) \\
\text { Local }\end{array}$ & $\begin{array}{c}(2) \\
\text { Local }\end{array}$ & $\begin{array}{c}(3) \\
\text { Local }\end{array}$ & $\begin{array}{c}(4) \\
\text { Rádio }\end{array}$ & $\begin{array}{c}(5) \\
\text { Rádio }\end{array}$ & $\begin{array}{c}(6) \\
\text { Rádio }\end{array}$ \\
\hline Pentecostais & $\begin{array}{l}-0.209^{\ddagger} \\
(-1.95)\end{array}$ & & & $\begin{array}{l}-0.163 \\
(-1.64)\end{array}$ & & \\
\hline Tradicionais & & $\begin{array}{r}0.353 \\
(1.52)\end{array}$ & & & $\begin{array}{r}0.271 \\
(1.41)\end{array}$ & \\
\hline Católicos & & & $\begin{array}{l}0.264^{* *} \\
(3.13)\end{array}$ & & & $\begin{array}{l}0.262^{* * *} \\
(3.39)\end{array}$ \\
\hline Idade & $\begin{array}{l}0.0175^{* * *} \\
(5.52)\end{array}$ & $\begin{array}{l}0.0181^{* * *} \\
(5.75)\end{array}$ & $\begin{array}{l}0.0170^{* * *} \\
(5.40)\end{array}$ & $\begin{array}{l}0.0174^{* * *} \\
(6.26)\end{array}$ & $\begin{array}{l}0.0178^{* * *} \\
(6.45)\end{array}$ & $\begin{array}{l}0.0168^{* * *} \\
(6.06)\end{array}$ \\
\hline Gênero & $\begin{array}{l}-0.147 \\
(-1.78)\end{array}$ & $\begin{array}{l}-0.158 \\
(-1.91)\end{array}$ & $\begin{array}{l}-0.149 \\
(-1.80)\end{array}$ & $\begin{array}{l}-0.340^{* * *} \\
(-4.55)\end{array}$ & $\begin{array}{l}-0.348^{* * *} \\
(-4.66)\end{array}$ & $\begin{array}{l}-0.341^{* * *} \\
(-4.56)\end{array}$ \\
\hline Escolaridade & $\begin{array}{l}0.130^{* * *} \\
(6.19)\end{array}$ & $\begin{array}{l}0.131^{* * *} \\
(6.27)\end{array}$ & $\begin{array}{l}0.134^{* * *} \\
(6.39)\end{array}$ & $\begin{array}{l}0.0381^{*} \\
(2.06)\end{array}$ & $\begin{array}{l}0.0393^{*} \\
(2.12)\end{array}$ & $\begin{array}{l}0.0417^{*} \\
(2.25)\end{array}$ \\
\hline Renda & $\begin{array}{l}0.0195 \\
(0.61)\end{array}$ & $\begin{array}{l}0.0189 \\
(0.59)\end{array}$ & $\begin{array}{l}0.0177 \\
(0.56)\end{array}$ & $\begin{array}{l}0.00760 \\
(0.27)\end{array}$ & $\begin{array}{l}0.00724 \\
(0.25)\end{array}$ & $\begin{array}{l}0.00616 \\
(0.22)\end{array}$ \\
\hline Raça & $\begin{array}{l}-0.0585 \\
(-1.05)\end{array}$ & $\begin{array}{l}-0.0496 \\
(-0.90)\end{array}$ & $\begin{array}{l}-0.0645 \\
(-1.17)\end{array}$ & $\begin{array}{l}0.0360 \\
(0.70)\end{array}$ & $\begin{array}{l}0.0428 \\
(0.83)\end{array}$ & $\begin{array}{l}0.0284 \\
(0.55)\end{array}$ \\
\hline Ocupação & $\begin{array}{r}0.148 \\
(0.63)\end{array}$ & $\begin{array}{c}0.144 \\
(0.62)\end{array}$ & $\begin{array}{r}0.155 \\
(0.66)\end{array}$ & $\begin{array}{l}-0.552^{*} \\
(-2.36)\end{array}$ & $\begin{array}{l}-0.555^{*} \\
(-2.35)\end{array}$ & $\begin{array}{l}-0.545^{*} \\
(-2.35)\end{array}$ \\
\hline Região & $\begin{array}{l}-0.00625 \\
(-0.13)\end{array}$ & $\begin{array}{l}-0.00878 \\
(-0.19)\end{array}$ & $\begin{array}{l}0.00153 \\
(0.03)\end{array}$ & $\begin{array}{l}0.0944^{*} \\
(2.24)\end{array}$ & $\begin{array}{l}0.0927^{*} \\
(2.20)\end{array}$ & $\begin{array}{l}0.102^{*} \\
(2.42)\end{array}$ \\
\hline Religiosidade & $\begin{array}{r}0.168 \\
(1.95)\end{array}$ & $\begin{array}{r}0.117 \\
(1.39)\end{array}$ & $\begin{array}{r}0.163 \\
(1.93)\end{array}$ & $\begin{array}{l}0.00197 \\
(0.03)\end{array}$ & $\begin{array}{l}-0.0369 \\
(-0.48)\end{array}$ & $\begin{array}{l}0.00486 \\
(0.06)\end{array}$ \\
\hline Constante & $\begin{array}{l}-0.0916 \\
(-0.30)\end{array}$ & $\begin{array}{l}-0.144 \\
(-0.47)\end{array}$ & $\begin{array}{l}-0.286 \\
(-0.92)\end{array}$ & $\begin{array}{l}-0.895^{* *} \\
(-3.29)\end{array}$ & $\begin{array}{l}-0.938^{* * *} \\
(-3.46)\end{array}$ & $\begin{array}{l}-1.081^{* * *} \\
(-3.93)\end{array}$ \\
\hline Observações & 3049 & 3049 & 3049 & 3049 & 3049 & 3049 \\
\hline
\end{tabular}

Estatística $t$ entre parênteses

${ }^{\ddagger} p<0.10 * p<0.05,{ }^{* *} p<0.01,{ }^{* * *} p<0.001$

Nota: elaborado pelo autor a partir dos dados do Estudo Eleitoral Brasileiro (ESEB, 2014). Nos modelos de 1 a 3, a variável dependente assume valor 1 se o indivíduo tem o hábito de assistir ao noticiário local e 0 , caso contrário. Nos modelos de 4 a 6, a variável dependente assume valor 1 se o indivíduo tem o hábito de se informar ouvindo rádio e 0 , caso contrário. 
Tabela 21 - Frequência à igreja e confiança nas lideranças da igreja por filiação religiosa (2014)

\begin{tabular}{|c|c|c|c|c|c|c|}
\hline & $\begin{array}{c}(1) \\
\text { Frequência }\end{array}$ & $\begin{array}{c}(2) \\
\text { Frequência }\end{array}$ & $\begin{array}{c}\text { (3) } \\
\text { Frequência }\end{array}$ & $\begin{array}{c}(4) \\
\text { Confiança }\end{array}$ & $\begin{array}{c}(5) \\
\text { Confiança }\end{array}$ & $\begin{array}{c}(6) \\
\text { Confiança }\end{array}$ \\
\hline Pentecostais & $\begin{array}{c}1.444^{* * *} \\
(11.95)\end{array}$ & & & $\begin{array}{c}1.222^{\text {*** }} \\
(11.16)\end{array}$ & & \\
\hline Tradicionais & & $\begin{array}{l}0.830^{* * *} \\
(3.56)\end{array}$ & & & $\begin{array}{c}0.114 \\
(0.50)\end{array}$ & \\
\hline Católicos & & & $\begin{array}{l}-0.760^{* * *} \\
(-8.31)\end{array}$ & & & $\begin{array}{l}1.141^{* * *} \\
(9.76)\end{array}$ \\
\hline Idade & $\begin{array}{l}0.0152^{* * *} \\
(4.55)\end{array}$ & $\begin{array}{l}0.0106^{* *} \\
(3.25)\end{array}$ & $\begin{array}{l}0.0136^{* * *} \\
(4.13)\end{array}$ & $\begin{array}{l}-0.00712 \\
(-1.91)\end{array}$ & $\begin{array}{l}-0.0108^{* *} \\
(-3.01)\end{array}$ & $\begin{array}{l}-0.00117 \\
(-0.33)\end{array}$ \\
\hline Gênero & $\begin{array}{l}0.499^{* * *} \\
(5.44)\end{array}$ & $\begin{array}{l}0.527^{* * *} \\
(5.91)\end{array}$ & $\begin{array}{l}0.525^{* * *} \\
(5.84)\end{array}$ & $\begin{array}{r}0.178 \\
(1.78)\end{array}$ & $\begin{array}{l}0.227^{*} \\
(2.32)\end{array}$ & $\begin{array}{r}0.171 \\
(1.77)\end{array}$ \\
\hline Escolaridade & $\begin{array}{l}0.0711^{* *} \\
(3.18)\end{array}$ & $\begin{array}{l}0.0482^{*} \\
(2.19)\end{array}$ & $\begin{array}{l}0.0474^{*} \\
(2.14)\end{array}$ & $\begin{array}{l}-0.0592^{*} \\
(-2.29)\end{array}$ & $\begin{array}{l}-0.0743^{* *} \\
(-3.01)\end{array}$ & $\begin{array}{l}-0.0551^{*} \\
(-2.32)\end{array}$ \\
\hline Renda & $\begin{array}{l}-0.00254 \\
(-0.07)\end{array}$ & $\begin{array}{l}0.00139 \\
(0.04)\end{array}$ & $\begin{array}{l}0.00278 \\
(0.08)\end{array}$ & $\begin{array}{l}0.0340 \\
(0.87)\end{array}$ & $\begin{array}{l}0.0378 \\
(1.00)\end{array}$ & $\begin{array}{l}-0.0337 \\
(-0.88)\end{array}$ \\
\hline Raça & $\begin{array}{l}-0.0808 \\
(-1.25)\end{array}$ & $\begin{array}{l}-0.132^{*} \\
(-2.08)\end{array}$ & $\begin{array}{l}-0.0962 \\
(-1.52)\end{array}$ & $\begin{array}{l}-0.0564 \\
(-0.80)\end{array}$ & $\begin{array}{l}-0.110 \\
(-1.57)\end{array}$ & $\begin{array}{l}-0.0573 \\
(-0.84)\end{array}$ \\
\hline Ocupação & $\begin{array}{c}0.469 \\
(1.63)\end{array}$ & $\begin{array}{c}0.514 \\
(1.84)\end{array}$ & $\begin{array}{r}0.482 \\
(1.72)\end{array}$ & $\begin{array}{r}0.187 \\
(0.71)\end{array}$ & $\begin{array}{r}0.228 \\
(0.84)\end{array}$ & $\begin{array}{c}-0.339 \\
(-1.04)\end{array}$ \\
\hline Região & $\begin{array}{l}-0.188^{* * *} \\
(-3.63)\end{array}$ & $\begin{array}{l}-0.165^{* *} \\
(-3.21)\end{array}$ & $\begin{array}{l}-0.190^{* * *} \\
(-3.71)\end{array}$ & $\begin{array}{l}-0.0171 \\
(-0.30)\end{array}$ & $\begin{array}{l}0.00119 \\
(0.02)\end{array}$ & $\begin{array}{l}-0.168^{* *} \\
(-3.08)\end{array}$ \\
\hline Religiosidade & $\begin{array}{l}2.341^{* * *} \\
(23.77)\end{array}$ & $\begin{array}{l}2.411^{* * *} \\
(24.98)\end{array}$ & $\begin{array}{l}2.418^{* * *} \\
(24.66)\end{array}$ & $\begin{array}{l}0.455^{* * *} \\
(4.29)\end{array}$ & $\begin{array}{l}0.673^{* * *} \\
(6.59)\end{array}$ & $\begin{array}{l}0.437^{* * *} \\
(4.32)\end{array}$ \\
\hline Constante & $\begin{array}{l}-3.102^{* * *} \\
(-9.23)\end{array}$ & $\begin{array}{l}-2.609^{* * *} \\
(-8.00)\end{array}$ & $\begin{array}{l}-2.261^{* * *} \\
(-6.93)\end{array}$ & $\begin{array}{l}-1.730^{* * *} \\
(-4.50)\end{array}$ & $\begin{array}{l}-1.356^{* * *} \\
(-3.76)\end{array}$ & $\begin{array}{l}-1.702^{* * *} \\
(-4.59)\end{array}$ \\
\hline Observações & 3049 & 3049 & 3049 & 3049 & 3049 & 3049 \\
\hline
\end{tabular}

Estatística $t$ entre parênteses.

${ }^{\ddagger} p<0.10 * p<0.05,{ }^{* *} p<0.01,{ }^{* * *} p<0.001$

Nota: elaborado pelo autor a partir dos dados do Estudo Eleitoral Brasileiro (ESEB, 2014). Nos modelos de 1 a 3, a variável dependente assume o valor 1 se o indivíduo frequenta a Missa ou o culto religioso pelo menos uma vez por semana e 0 , caso contrário. Nos modelos de 4 a 6 , a variável dependente assume valor 1 se o indivíduo avalia a atuação da sua igreja como ótima ou boa e 0 , caso contrário. 
Tabela 22 - Nível de simpatia pelo petismo por filiação religiosa (2017)

\begin{tabular}{lccc}
\hline \hline & $(1)$ & $(2)$ & $(3)$ \\
& Petismo & Petismo & Petismo \\
\hline Pentecostais & $-0.702^{*}$ & & \\
Tradicionais & $(-2.41)$ & & \\
Católicos & & -0.104 & \\
& & $(-0.31)$ & 0.191 \\
Gênero & & & $(0.92)$ \\
& 0.101 & 0.129 & 0.116 \\
Raça & $(0.47)$ & $(0.61)$ & $(0.54)$ \\
Escolaridade & 0.0673 & 0.0689 & 0.0690 \\
& $(1.11)$ & $(1.14)$ & $(1.15)$ \\
Renda & $-0.225^{* *}$ & $-0.224^{* *}$ & $-0.220^{* *}$ \\
& $(-2.89)$ & $(-2.87)$ & $(-2.83)$ \\
Região & $-0.0711^{* *}$ & $-0.0674^{*}$ & $-0.0675^{*}$ \\
& $(-2.63)$ & $(-2.53)$ & $(-2.52)$ \\
Religiosidade & 0.0108 & 0.0310 & 0.0267 \\
& $(0.14)$ & $(0.41)$ & $(0.35)$ \\
Constante & 0.346 & 0.273 & 0.264 \\
& $(1.20)$ & $(0.95)$ & $(0.92)$ \\
Observações & $-1.765^{* * *}$ & $-1.930^{* * *}$ & $-2.021^{* * *}$ \\
\hline \hline Estatsticat & $(-3.56)$ & $(-3.92)$ & $(-3.93)$ \\
\hline
\end{tabular}

Estatística $t$ entre parênteses

${ }^{*} p<0.05,{ }^{* *} p<0.01,{ }^{* * *} p<0.001$

Nota: elaborado pelo autor a partir dos dados do LAPOP (2017). A variável dependente assume valor 1 se o indivíduo gosta muito do PT e seus simpatizantes e 0 , caso contrário. 
Tabela 23 - Apoio a pautas morais por filiação religiosa (2015)

\begin{tabular}{|c|c|c|c|c|c|c|}
\hline & $\begin{array}{c}(1) \\
\text { Maconha }\end{array}$ & $\begin{array}{c}(2) \\
\text { Maconha }\end{array}$ & $\begin{array}{c}\text { (3) } \\
\text { Maconha }\end{array}$ & $\begin{array}{c}(4) \\
\text { Homoafetivo }\end{array}$ & $\begin{array}{c}(5) \\
\text { Homoafetivo }\end{array}$ & $\begin{array}{c}(6) \\
\text { Homoafetivo }\end{array}$ \\
\hline Pentecostais & $\begin{array}{l}-0.614^{* *} \\
(-2.82)\end{array}$ & & & $\begin{array}{l}-1.222^{* * *} \\
(-6.76)\end{array}$ & & \\
\hline Tradicionais & & $\begin{array}{l}-0.0185 \\
(-0.05)\end{array}$ & & & $\begin{array}{l}-0.887^{*} \\
(-2.33)\end{array}$ & \\
\hline Católicos & & & $\begin{array}{l}0.0548 \\
(0.36)\end{array}$ & & & $\begin{array}{l}0.554^{* * *} \\
(4.31)\end{array}$ \\
\hline Idade & $\begin{array}{l}-0.0350^{* * *} \\
(-5.76)\end{array}$ & $\begin{array}{l}-0.0334^{* * *} \\
(-5.54)\end{array}$ & $\begin{array}{l}-0.0335^{* * *} \\
(-5.56)\end{array}$ & $\begin{array}{l}-0.0304^{* * *} \\
(-6.52)\end{array}$ & $\begin{array}{l}-0.0271^{* * *} \\
(-5.94)\end{array}$ & $\begin{array}{l}-0.0288^{* * *} \\
(-6.28)\end{array}$ \\
\hline Gênero & $\begin{array}{l}-0.302^{*} \\
(-2.02)\end{array}$ & $\begin{array}{l}-0.296^{*} \\
(-1.98)\end{array}$ & $\begin{array}{l}-0.297^{*} \\
(-2.00)\end{array}$ & $\begin{array}{l}0.530^{* * *} \\
(4.11)\end{array}$ & $\begin{array}{l}0.500^{* * *} \\
(3.95)\end{array}$ & $\begin{array}{l}0.500^{* * *} \\
(3.93)\end{array}$ \\
\hline Escolaridade & $\begin{array}{l}0.0428 \\
(1.84)\end{array}$ & $\begin{array}{l}0.0470^{*} \\
(2.02)\end{array}$ & $\begin{array}{l}0.0474^{*} \\
(2.02)\end{array}$ & $\begin{array}{l}0.0651^{* * *} \\
(3.57)\end{array}$ & $\begin{array}{l}0.0731^{\text {*** }} \\
(4.03)\end{array}$ & $\begin{array}{l}0.0762^{\text {*** }} \\
(4.15)\end{array}$ \\
\hline Raça & $\begin{array}{l}0.0137 \\
(0.33)\end{array}$ & $\begin{array}{l}0.0232 \\
(0.56)\end{array}$ & $\begin{array}{l}0.0210 \\
(0.50)\end{array}$ & $\begin{array}{l}0.0386 \\
(1.12)\end{array}$ & $\begin{array}{l}0.0553 \\
(1.67)\end{array}$ & $\begin{array}{l}0.0333 \\
(0.98)\end{array}$ \\
\hline Religiosidade & $\begin{array}{l}-0.220 \\
(-1.36)\end{array}$ & $\begin{array}{l}-0.354^{*} \\
(-2.27)\end{array}$ & $\begin{array}{l}-0.351^{*} \\
(-2.25)\end{array}$ & $\begin{array}{l}-0.482^{* * *} \\
(-3.48)\end{array}$ & $\begin{array}{l}-0.709^{* * *} \\
(-5.44)\end{array}$ & $\begin{array}{l}-0.697^{* * *} \\
(-5.31)\end{array}$ \\
\hline Constante & $\begin{array}{l}-0.0341 \\
(-0.07)\end{array}$ & $\begin{array}{l}-0.250 \\
(-0.51)\end{array}$ & $\begin{array}{l}-0.268 \\
(-0.54)\end{array}$ & $\begin{array}{l}-0.460 \\
(-1.14)\end{array}$ & $\begin{array}{l}-0.809^{*} \\
(-2.06)\end{array}$ & $\begin{array}{l}-1.025^{*} \\
(-2.57)\end{array}$ \\
\hline Observações & 1250 & 1250 & 1250 & 1250 & 1250 & 1250 \\
\hline
\end{tabular}

Estatística $t$ entre parênteses.

${ }^{\ddagger} p<0.10 * p<0.05,{ }^{* *} p<0.01,{ }^{* * *} p<0.001$

Nota: elaborado pelo autor a partir dos dados do Latinobarômetro (2015). Nos modelos de 1 a 3, a variável dependente assume valor 1 se o indivíduo concorda muito ou concorda com a legalização da maconha e 0 , caso contrário. Nos modelos de 4 a 6, a variável dependente assume valor 1 se o indivíduo concorda muito ou concorda com a união de casais homoafetivos. 
Tabela 24 - Voto no PT nas eleições presidenciais por filiação religiosa - nível municipal (2006-2018)

\begin{tabular}{|c|c|c|c|c|c|c|}
\hline & $\begin{array}{c}(1) \\
\text { PT (2006) }\end{array}$ & $\begin{array}{c}(2) \\
\text { PT (2006) }\end{array}$ & $\begin{array}{c}\text { (3) } \\
\text { PT (2006) }\end{array}$ & $\begin{array}{c}(4) \\
\text { PT }(2010)\end{array}$ & $\begin{array}{c}(5) \\
\text { PT (2010) }\end{array}$ & $\begin{array}{c}(6) \\
\text { PT (2010) }\end{array}$ \\
\hline Pentecostais & $\begin{array}{l}-0.0785^{* *} \\
(-2.92)\end{array}$ & & & $\begin{array}{l}-0.442^{* * *} \\
(-17.49)\end{array}$ & & \\
\hline Tradicionais & & $\begin{array}{l}0.0510^{\ddagger} \\
(1.79)\end{array}$ & & & $\begin{array}{l}0.0174 \\
(0.50)\end{array}$ & \\
\hline Católicos & & & $\begin{array}{l}0.00956 \\
(0.69)\end{array}$ & & & $\begin{array}{l}0.200^{* * *} \\
(14.81)\end{array}$ \\
\hline Analfabetismo & $\begin{array}{l}0.373^{* * *} \\
(12.32)\end{array}$ & $\begin{array}{l}0.400^{* * *} \\
(13.31)\end{array}$ & $\begin{array}{c}0.388^{* * *} \\
(12.82)\end{array}$ & $\begin{array}{l}0.133^{* * *} \\
(4.86)\end{array}$ & $\begin{array}{l}0.242^{* * *} \\
(8.77)\end{array}$ & $\begin{array}{l}0.146^{* * *} \\
(5.36)\end{array}$ \\
\hline Pobreza & $\begin{array}{l}0.334^{* * *} \\
(10.03)\end{array}$ & $\begin{array}{l}0.340^{* * *} \\
(10.13)\end{array}$ & $\begin{array}{l}0.333^{* * *} \\
(9.95)\end{array}$ & $\begin{array}{l}0.111^{* * *} \\
(3.55)\end{array}$ & $\begin{array}{l}0.112^{* * *} \\
(3.41)\end{array}$ & $\begin{array}{l}0.0831^{* *} \\
(2.60)\end{array}$ \\
\hline Renda per capita & $\begin{array}{l}-0.0120^{* * *} \\
(-4.17)\end{array}$ & $\begin{array}{l}-0.0119^{* * *} \\
(-4.13)\end{array}$ & $\begin{array}{l}-0.0121^{* * *} \\
(-4.18)\end{array}$ & $\begin{array}{l}-0.0171^{* * *} \\
(-6.31)\end{array}$ & $\begin{array}{l}-0.0182^{* * *} \\
(-6.21)\end{array}$ & $\begin{array}{l}-0.0158^{* * *} \\
(-5.53)\end{array}$ \\
\hline Gini & $\begin{array}{l}-4.509 \\
(-1.29)\end{array}$ & $\begin{array}{l}-5.145 \\
(-1.47)\end{array}$ & $\begin{array}{l}-4.925 \\
(-1.41)\end{array}$ & $\begin{array}{l}8.578^{* *} \\
(2.71)\end{array}$ & $\begin{array}{r}5.857 \\
(1.78)\end{array}$ & $\begin{array}{l}6.989^{*} \\
(2.19)\end{array}$ \\
\hline Formalização & $\begin{array}{l}-0.0277 \\
(-1.74)\end{array}$ & $\begin{array}{l}-0.0305 \\
(-1.93)\end{array}$ & $\begin{array}{l}-0.0310 \\
(-1.95)\end{array}$ & $\begin{array}{l}-0.0851^{* * *} \\
(-5.76)\end{array}$ & $\begin{array}{l}-0.108^{* * *} \\
(-7.12)\end{array}$ & $\begin{array}{l}-0.0917^{* * *} \\
(-6.16)\end{array}$ \\
\hline Desocupação & $\begin{array}{l}0.259^{* * *} \\
(6.53)\end{array}$ & $\begin{array}{l}0.238^{* * *} \\
(6.22)\end{array}$ & $\begin{array}{l}0.243^{* * *} \\
(6.08)\end{array}$ & $\begin{array}{l}0.0532 \\
(1.63)\end{array}$ & $\begin{array}{l}-0.0741^{*} \\
(-2.34)\end{array}$ & $\begin{array}{l}0.0731^{*} \\
(2.12)\end{array}$ \\
\hline IDHM & $\begin{array}{l}27.48^{* * *} \\
(5.71)\end{array}$ & $\begin{array}{l}30.60^{* * *} \\
(6.33)\end{array}$ & $\begin{array}{l}29.12^{* * *} \\
(5.92)\end{array}$ & $\begin{array}{l}-28.06^{* * *} \\
(-6.48)\end{array}$ & $\begin{array}{l}-14.42^{* *} \\
(-3.18)\end{array}$ & $\begin{array}{l}-29.80^{* * *} \\
(-6.77)\end{array}$ \\
\hline PBF (2006) & $\begin{array}{l}0.000303^{* * *} \\
(3.75)\end{array}$ & $\begin{array}{l}0.000302^{* * *} \\
(3.76)\end{array}$ & $\begin{array}{l}0.000306^{* * *} \\
(3.75)\end{array}$ & & & \\
\hline PBF (2010) & & & & $0.000120^{* * *}$ & $0.000119^{* * *}$ & $0.000149^{* * *}$ \\
\hline Região & $\begin{array}{c}-3.192^{* * *} \\
(-16.57)\end{array}$ & $\begin{array}{l}-3.184^{* * *} \\
(-16.44)\end{array}$ & $\begin{array}{l}-3.192^{* * *} \\
(-16.60)\end{array}$ & $\begin{array}{c}-0.0621 \\
(-0.35) \\
(5.34)\end{array}$ & $\begin{array}{c}-0.0449 \\
(-0.24) \\
(5.70)\end{array}$ & $\begin{array}{r}-0.131 \\
(-0.75) \\
(5.60)\end{array}$ \\
\hline Constante & $\begin{array}{l}21.73^{* * *} \\
(5.86) \\
\end{array}$ & $\begin{array}{l}18.69^{* * *} \\
(4.93) \\
\end{array}$ & $\begin{array}{l}19.58^{* * *} \\
(5.17) \\
\end{array}$ & $\begin{array}{l}68.35^{* * *} \\
(19.89) \\
\end{array}$ & $\begin{array}{l}57.51^{* * *} \\
(15.68) \\
\end{array}$ & $\begin{array}{l}51.39^{* * *} \\
(14.28) \\
\end{array}$ \\
\hline Observações & 5562 & 5562 & 5562 & 5562 & 5562 & 5562 \\
\hline
\end{tabular}

${ }_{\ddagger}^{\ddagger} p<0.10^{*} p<0.05, * * p<0.01,{ }^{* * *} p<0.001$

Nota: elaborado pelo autor a partir dos dados do Instituto Brasileiro de Geografia e Estatística (IBGE) e do Tribunal Superior Eleitoral (TSE). A variável dependente é a proporção de votos válidos do PT nas eleições de 2006 e 2010. 
Tabela 25 - Voto no PT nas eleições presidenciais por filiação religiosa - nível municipal (2006-2018) - continuação

\begin{tabular}{|c|c|c|c|c|c|c|}
\hline & $\begin{array}{c}(1) \\
\text { PT (2014) }\end{array}$ & $\begin{array}{c}(2) \\
\text { PT (2014) }\end{array}$ & $\begin{array}{c}(3) \\
\text { PT (2014) }\end{array}$ & $\begin{array}{c}(4) \\
\text { PT (2018) }\end{array}$ & $\begin{array}{c}(5) \\
\text { PT (2018) }\end{array}$ & $\begin{array}{c}(6) \\
\text { PT (2018) }\end{array}$ \\
\hline Pentecostais & $\begin{array}{c}-0.486^{* * *} \\
(-19.94)\end{array}$ & & & $\begin{array}{c}-0.459^{* * *} \\
(-19.41)\end{array}$ & & \\
\hline Tradicionais & & $\begin{array}{l}0.0682^{\ddagger} \\
(1.95)\end{array}$ & & & $\begin{array}{l}-0.0314 \\
(-1.19)\end{array}$ & \\
\hline Católicos & & & $\begin{array}{c}0.193^{* * *} \\
(14.43)\end{array}$ & & & $\begin{array}{c}0.172^{* * *} \\
(13.48)\end{array}$ \\
\hline Analfabetos & $\begin{array}{l}0.0419 \\
(1.63)\end{array}$ & $\begin{array}{l}0.169^{* * *} \\
(6.64)\end{array}$ & $\begin{array}{l}0.0687^{* *} \\
(2.70)\end{array}$ & $\begin{array}{l}0.135^{* * *} \\
(4.78)\end{array}$ & $\begin{array}{l}0.241^{* * *} \\
(8.44)\end{array}$ & $\begin{array}{l}0.165^{* * *} \\
(5.89)\end{array}$ \\
\hline Pobreza & $\begin{array}{l}0.318^{* * *} \\
(10.62)\end{array}$ & $\begin{array}{c}0.325^{* * *} \\
(10.18)\end{array}$ & $\begin{array}{l}0.291^{* * *} \\
(9.40)\end{array}$ & $\begin{array}{c}0.504^{* * *} \\
(18.30)\end{array}$ & $\begin{array}{l}0.500^{* * *} \\
(17.30)\end{array}$ & $\begin{array}{c}0.480^{* * *} \\
(16.97)\end{array}$ \\
\hline Renda per capita & $\begin{array}{l}-0.0109^{* * *} \\
(-4.47)\end{array}$ & $\begin{array}{l}-0.0117^{* * *} \\
(-4.39)\end{array}$ & $\begin{array}{l}-0.00965^{* * *} \\
(-3.71)\end{array}$ & $\begin{array}{l}0.00898^{* * *} \\
(4.27)\end{array}$ & $\begin{array}{l}0.00762^{* * *} \\
(3.37)\end{array}$ & $\begin{array}{l}0.00999^{* * *} \\
(4.52)\end{array}$ \\
\hline Gini & $\begin{array}{l}9.894^{* * *} \\
(3.36)\end{array}$ & $\begin{array}{l}6.731^{*} \\
(2.18)\end{array}$ & $\begin{array}{l}8.033^{* *} \\
(2.70)\end{array}$ & $\begin{array}{l}-6.048^{*} \\
(-2.00)\end{array}$ & $\begin{array}{l}-8.719^{* *} \\
(-2.78)\end{array}$ & $\begin{array}{l}-7.861^{*} \\
(-2.56)\end{array}$ \\
\hline Formalização & $\begin{array}{l}-0.115^{\text {*** }} \\
(-7.59)\end{array}$ & $\begin{array}{l}-0.139^{* * *} \\
(-8.72)\end{array}$ & $\begin{array}{l}-0.125^{* * *} \\
(-8.07)\end{array}$ & $\begin{array}{l}-0.0391^{* *} \\
(-2.75)\end{array}$ & $\begin{array}{l}-0.0642^{* * *} \\
(-4.37)\end{array}$ & $\begin{array}{l}-0.0490^{* * *} \\
(-3.42)\end{array}$ \\
\hline Desocupação & $\begin{array}{l}-0.0310 \\
(-1.02)\end{array}$ & $\begin{array}{l}-0.169^{* * *} \\
(-5.39)\end{array}$ & $\begin{array}{l}-0.0274 \\
(-0.86)\end{array}$ & $\begin{array}{l}0.212^{* * *} \\
(6.31)\end{array}$ & $\begin{array}{l}0.0780^{*} \\
(2.38)\end{array}$ & $\begin{array}{l}0.208^{* * *} \\
(5.91)\end{array}$ \\
\hline IDHM & $\begin{array}{l}-30.64^{* * *} \\
(-7.37)\end{array}$ & $\begin{array}{l}-14.94^{* * *} \\
(-3.48)\end{array}$ & $\begin{array}{l}-30.48^{* * *} \\
(-7.22)\end{array}$ & $\begin{array}{l}-68.13^{* * *} \\
(-16.16)\end{array}$ & $\begin{array}{l}-54.69^{* * *} \\
(-12.39)\end{array}$ & $\begin{array}{l}-67.21^{* * *} \\
(-15.56)\end{array}$ \\
\hline PBF (2014) & $\begin{array}{l}0.0000862^{* * *} \\
(3.62)\end{array}$ & $\begin{array}{l}0.0000828^{* * *} \\
(3.80)\end{array}$ & $\begin{array}{l}0.000105^{* * *} \\
(3.63)\end{array}$ & & & \\
\hline PBF (2018) & & & & $\begin{array}{l}0.0000349^{*} \\
(2.44)\end{array}$ & $\begin{array}{l}0.0000338^{*} \\
(2.21)\end{array}$ & $\begin{array}{l}0.0000512^{* *} \\
(2.93)\end{array}$ \\
\hline Região & $\begin{array}{l}-1.181^{\text {*** }} \\
(-7.16)\end{array}$ & $\begin{array}{l}-1.159^{* * *} \\
(-6.62)\end{array}$ & $\begin{array}{l}-1.252^{* * *} \\
(-7.53)\end{array}$ & $\begin{array}{l}-0.637^{* * *} \\
(-3.92)\end{array}$ & $\begin{array}{l}-0.625^{* * *} \\
(-3.57)\end{array}$ & $\begin{array}{l}-0.700^{* * *} \\
(-4.28)\end{array}$ \\
\hline Constante & $\begin{array}{c}58.76^{* * *} \\
(17.49)\end{array}$ & $\begin{array}{l}45.68^{* * *} \\
(12.87)\end{array}$ & $\begin{array}{l}40.92^{* * *} \\
(11.76)\end{array}$ & $\begin{array}{l}47.89^{* * *} \\
(14.76)\end{array}$ & $\begin{array}{l}37.78^{* * *} \\
(10.93)\end{array}$ & $\begin{array}{l}31.39^{* * *} \\
(9.37)\end{array}$ \\
\hline Observações & 5562 & 5562 & 5562 & 5562 & 5562 & 5562 \\
\hline
\end{tabular}

${ }^{\ddagger} p<0.10^{*} p<0.05,{ }^{* *} p<0.01,{ }^{* * *} p<0.001$

Nota: elaborado pelo autor a partir dos dados do Instituto Brasileiro de Geografia e Estatística (IBGE) e do Tribunal Superior Eleitoral (TSE). A variável dependente é a proporção de votos válidos do PT nas eleições de 2014 e 2018. 
Tabela 26 - Voto no PT nas eleições presidenciais por filiação religiosa - nível individual (2006)

\begin{tabular}{|c|c|c|}
\hline & $\begin{array}{c}(1) \\
\text { PT (2006) }\end{array}$ & $\begin{array}{c}(2) \\
\text { PT (2006) }\end{array}$ \\
\hline Evangélicos & $\begin{array}{l}-0.407^{*} \\
(-2.10)\end{array}$ & \\
\hline Católicos & & $\begin{array}{c}0.358^{*} \\
(1.96)\end{array}$ \\
\hline Gênero & $\begin{array}{l}0.0990 \\
(0.58)\end{array}$ & $\begin{array}{c}0.0957 \\
(0.56)\end{array}$ \\
\hline Idade & $\begin{array}{l}-0.00395 \\
(-0.67)\end{array}$ & $\begin{array}{l}-0.00333 \\
(-0.56)\end{array}$ \\
\hline Raça & $\begin{array}{l}0.0199 \\
(0.26)\end{array}$ & $\begin{array}{l}0.0183 \\
(0.24)\end{array}$ \\
\hline Escolaridade & $\begin{array}{c}-0.253 \\
(-1.82)\end{array}$ & $\begin{array}{c}-0.233 \\
(-1.68)\end{array}$ \\
\hline Renda & $\begin{array}{l}-0.116^{*} \\
(-2.32)\end{array}$ & $\begin{array}{l}-0.114^{*} \\
(-2.30)\end{array}$ \\
\hline Urbano & $\begin{array}{l}-0.0641 \\
(-0.26)\end{array}$ & $\begin{array}{l}-0.0629 \\
(-0.25)\end{array}$ \\
\hline PBF & $\begin{array}{c}0.522 \\
(1.71)\end{array}$ & $\begin{array}{c}0.528 \\
(1.73)\end{array}$ \\
\hline Gov. avaliação & $\begin{array}{l}1.424^{* * *} \\
(7.85)\end{array}$ & $\begin{array}{l}1.424^{* * *} \\
(7.86)\end{array}$ \\
\hline Percep.economia & $\begin{array}{c}0.138 \\
(0.60)\end{array}$ & $\begin{array}{c}0.132 \\
(0.57)\end{array}$ \\
\hline Percep. renda & $\begin{array}{l}-0.613^{* *} \\
(-3.23)\end{array}$ & $\begin{array}{l}-0.618^{* *} \\
(-3.26)\end{array}$ \\
\hline Pref. taxação & $\begin{array}{c}-0.219 \\
(-0.79)\end{array}$ & $\begin{array}{c}-0.223 \\
(-0.81)\end{array}$ \\
\hline Pref. redistribuição & $\begin{array}{c}-0.156 \\
(-0.85)\end{array}$ & $\begin{array}{c}-0.155 \\
(-0.85)\end{array}$ \\
\hline Freq. igreja & $\begin{array}{l}0.0718 \\
(1.40)\end{array}$ & $\begin{array}{l}0.0714 \\
(1.40)\end{array}$ \\
\hline Constante & $\begin{array}{l}1.555^{* *} \\
(2.75)\end{array}$ & $\begin{array}{c}1.141 \\
(1.92)\end{array}$ \\
\hline Observações & 888 & 888 \\
\hline
\end{tabular}

Estatística $t$ entre parênteses.

${ }_{\ddagger}^{\ddagger} p<0.10^{*} p<0.05,{ }^{* *} p<0.01,{ }^{* * *} p<0.001$

Nota: elaborado pelo autor a partir dos dados do LAPOP (2008). A variável dependente assume valor 1 se o indivíduo votou no PT nas eleições de 2006 e 0, caso contrário. 
Tabela 27 - Voto no PT nas eleições presidenciais por filiação religiosa - nível individual (2010 e 2014)

\begin{tabular}{|c|c|c|c|c|c|c|}
\hline & $\begin{array}{c}(1) \\
\text { PT (2010) }\end{array}$ & $\begin{array}{c}(2) \\
\text { PT }(2010)\end{array}$ & $\begin{array}{c}\text { (3) } \\
\text { PT (2010) }\end{array}$ & $\begin{array}{c}(4) \\
\text { PT }(2014)\end{array}$ & $\begin{array}{c}(5) \\
\text { PT (2014) }\end{array}$ & $\begin{array}{c}(6) \\
\text { PT }(2014)\end{array}$ \\
\hline Pentecostais & $\begin{array}{l}-0.180^{\ddagger} \\
(-1.73)\end{array}$ & & & $\begin{array}{l}-0.405^{* * *} \\
(-3.76)\end{array}$ & & \\
\hline Tradicionais & & $\begin{array}{l}0.521^{* *} \\
(2.64)\end{array}$ & & & $\begin{array}{l}-0.0730 \\
(-0.37)\end{array}$ & \\
\hline Católicos & & & $\begin{array}{l}0.161^{*} \\
(2.04)\end{array}$ & & & $\begin{array}{l}0.324^{* * *} \\
(3.99)\end{array}$ \\
\hline Idade & $\begin{array}{l}0.0177^{* * *} \\
(6.35)\end{array}$ & $\begin{array}{l}0.0183^{\text {*** }} \\
(6.58)\end{array}$ & $\begin{array}{l}0.0175^{\text {*** }} \\
(6.28)\end{array}$ & $\begin{array}{l}-0.00344 \\
(-1.21)\end{array}$ & $\begin{array}{l}-0.00240 \\
(-0.85)\end{array}$ & $\begin{array}{l}-0.00373 \\
(-1.31)\end{array}$ \\
\hline Gênero & $\begin{array}{l}-0.0770 \\
(-1.02)\end{array}$ & $\begin{array}{l}-0.0825 \\
(-1.09)\end{array}$ & $\begin{array}{l}-0.0794 \\
(-1.05)\end{array}$ & $\begin{array}{l}0.0547 \\
(0.70)\end{array}$ & $\begin{array}{l}0.0463 \\
(0.59)\end{array}$ & $\begin{array}{l}0.0487 \\
(0.62)\end{array}$ \\
\hline Escolaridade & $\begin{array}{l}0.00628 \\
(0.34)\end{array}$ & $\begin{array}{l}0.00731 \\
(0.39)\end{array}$ & $\begin{array}{l}0.00913 \\
(0.49)\end{array}$ & $\begin{array}{l}-0.0977^{* * *} \\
(-5.01)\end{array}$ & $\begin{array}{l}-0.0923^{* * *} \\
(-4.74)\end{array}$ & $\begin{array}{l}-0.0919^{* * *} \\
(-4.71)\end{array}$ \\
\hline Renda & $\begin{array}{l}0.0758^{* *} \\
(2.63)\end{array}$ & $\begin{array}{l}0.0759^{* *} \\
(2.62)\end{array}$ & $\begin{array}{l}0.0747^{* *} \\
(2.59)\end{array}$ & $\begin{array}{l}0.0739^{*} \\
(2.47)\end{array}$ & $\begin{array}{l}0.0727^{*} \\
(2.43)\end{array}$ & $\begin{array}{l}0.0712^{*} \\
(2.38)\end{array}$ \\
\hline Raça & $\begin{array}{l}-0.156^{* *} \\
(-2.96)\end{array}$ & $\begin{array}{l}-0.150^{* *} \\
(-2.84)\end{array}$ & $\begin{array}{l}-0.159^{* *} \\
(-3.00)\end{array}$ & $\begin{array}{l}-0.193^{* * *} \\
(-3.50)\end{array}$ & $\begin{array}{l}-0.181^{* *} \\
(-3.29)\end{array}$ & $\begin{array}{l}-0.197^{* * *} \\
(-3.55)\end{array}$ \\
\hline Ocupação & $\begin{array}{l}-0.270 \\
(-1.21)\end{array}$ & $\begin{array}{c}-0.262 \\
(-1.18)\end{array}$ & $\begin{array}{c}-0.266 \\
(-1.20)\end{array}$ & $\begin{array}{l}-0.0553 \\
(-0.24)\end{array}$ & $\begin{array}{l}-0.0568 \\
(-0.25)\end{array}$ & $\begin{array}{l}-0.0470 \\
(-0.21)\end{array}$ \\
\hline Percep. Economia & $\begin{array}{l}0.356^{* * *} \\
(4.33)\end{array}$ & $\begin{array}{l}0.363^{* * *} \\
(4.41)\end{array}$ & $\begin{array}{l}0.347^{* * *} \\
(4.21)\end{array}$ & $\begin{array}{c}0.892^{* * *} \\
(10.29)\end{array}$ & $\begin{array}{c}0.893^{* * *} \\
(10.34)\end{array}$ & $\begin{array}{c}0.875^{\text {*** }} \\
(10.09)\end{array}$ \\
\hline PBF & $\begin{array}{l}0.393^{* * *} \\
(4.43)\end{array}$ & $\begin{array}{l}0.387^{* * *} \\
(4.36)\end{array}$ & $\begin{array}{l}0.387^{* * *} \\
(4.37)\end{array}$ & $\begin{array}{l}0.467^{* * *} \\
(5.10)\end{array}$ & $\begin{array}{l}0.446^{* * *} \\
(4.90)\end{array}$ & $\begin{array}{l}0.453^{* * *} \\
(4.97)\end{array}$ \\
\hline Pref. Partido & $\begin{array}{l}0.660^{* *} \\
(2.70)\end{array}$ & $\begin{array}{l}0.668^{* *} \\
(2.74)\end{array}$ & $\begin{array}{l}0.666^{* *} \\
(2.74)\end{array}$ & $\begin{array}{c}0.184 \\
(0.77)\end{array}$ & $\begin{array}{c}0.212 \\
(0.89)\end{array}$ & $\begin{array}{c}0.205 \\
(0.86)\end{array}$ \\
\hline Região & $\begin{array}{l}-0.157^{* * *} \\
(-3.57)\end{array}$ & $\begin{array}{l}-0.161^{\text {*** }} \\
(-3.66)\end{array}$ & $\begin{array}{l}-0.154^{* * *} \\
(-3.50)\end{array}$ & $\begin{array}{l}-0.294^{* * *} \\
(-6.35)\end{array}$ & $\begin{array}{l}-0.301^{* * *} \\
(-6.54)\end{array}$ & $\begin{array}{l}-0.290^{* * *} \\
(-6.26)\end{array}$ \\
\hline Freq. Igreja & $\begin{array}{l}0.0296 \\
(0.36)\end{array}$ & $\begin{array}{l}-0.0391 \\
(-0.50)\end{array}$ & $\begin{array}{l}0.0162 \\
(0.20)\end{array}$ & $\begin{array}{l}0.0710 \\
(0.84)\end{array}$ & $\begin{array}{l}-0.0243 \\
(-0.30)\end{array}$ & $\begin{array}{l}0.0346 \\
(0.42)\end{array}$ \\
\hline Constante & $\begin{array}{c}-0.455 \\
(-1.57) \\
\end{array}$ & $\begin{array}{c}-0.507 \\
(-1.75) \\
\end{array}$ & $\begin{array}{l}-0.574^{*} \\
(-1.98) \\
\end{array}$ & $\begin{array}{l}0.722^{*} \\
(2.39) \\
\end{array}$ & $\begin{array}{l}0.634^{*} \\
(2.10) \\
\end{array}$ & $\begin{array}{c}0.479 \\
(1.58) \\
\end{array}$ \\
\hline Observações & 3049 & 3049 & 3049 & 3049 & 3049 & 3049 \\
\hline
\end{tabular}

Estatística $t$ entre parênteses.

${ }^{\ddagger} p<0.10^{*} p<0.05,{ }^{* *} p<0.01,{ }^{* * *} p<0.001$

Nota: elaborado pelo autor a partir dos dados do Estudo Eleitoral Brasileiro (ESEB, 2014). A variável dependente assume valor 1 se o indivíduo votou no PT nas eleições de 2010 e 2014 e 0, caso contrário. 
Tabela 28 - Voto no PT nas eleições presidenciais por filiação religiosa - nível individual (2018)

\begin{tabular}{|c|c|c|c|}
\hline & $\begin{array}{c}(1) \\
\text { PT (2018) }\end{array}$ & $\begin{array}{c}(2) \\
\text { PT (2018) }\end{array}$ & $\begin{array}{c}(3) \\
\text { PT (2018) }\end{array}$ \\
\hline Pentecostais & $\begin{array}{l}-0.784^{* * *} \\
(-5.73)\end{array}$ & & \\
\hline Tradicionais & & $\begin{array}{l}-0.786^{* * *} \\
(-5.19)\end{array}$ & \\
\hline Católicos & & & $\begin{array}{l}0.341^{\text {*** }} \\
(3.55)\end{array}$ \\
\hline Gênero & $\begin{array}{l}-0.286^{* *} \\
(-3.03)\end{array}$ & $\begin{array}{l}-0.277^{* *} \\
(-2.93)\end{array}$ & $\begin{array}{l}-0.279^{* *} \\
(-2.96)\end{array}$ \\
\hline Idade & $\begin{array}{l}-0.169^{* * *} \\
(-4.49)\end{array}$ & $\begin{array}{l}-0.176^{* * *} \\
(-4.60)\end{array}$ & $\begin{array}{l}-0.177^{* * *} \\
(-4.64)\end{array}$ \\
\hline Escolaridade & $\begin{array}{l}-0.0321 \\
(-1.05)\end{array}$ & $\begin{array}{l}-0.0280 \\
(-0.91)\end{array}$ & $\begin{array}{l}-0.0249 \\
(-0.82)\end{array}$ \\
\hline Renda & $\begin{array}{l}-0.0783 \\
(-1.83)\end{array}$ & $\begin{array}{l}-0.0709 \\
(-1.66)\end{array}$ & $\begin{array}{l}-0.0668 \\
(-1.56)\end{array}$ \\
\hline Raça & $\begin{array}{l}0.123^{* * *} \\
(3.40)\end{array}$ & $\begin{array}{l}0.120^{* * *} \\
(3.34)\end{array}$ & $\begin{array}{l}0.119^{* * *} \\
(3.33)\end{array}$ \\
\hline Desemprego & $\begin{array}{l}0.0250 \\
(0.13)\end{array}$ & $\begin{array}{l}0.0235 \\
(0.13)\end{array}$ & $\begin{array}{l}0.0194 \\
(0.10)\end{array}$ \\
\hline Pref. Partido & $\begin{array}{l}3.288^{* * *} \\
(24.40)\end{array}$ & $\begin{array}{l}3.319^{* * *} \\
(24.84)\end{array}$ & $\begin{array}{l}3.280^{* * *} \\
(24.62)\end{array}$ \\
\hline Região & $\begin{array}{l}0.0225 \\
(0.65)\end{array}$ & $\begin{array}{l}0.0266 \\
(0.77)\end{array}$ & $\begin{array}{l}0.0209 \\
(0.61)\end{array}$ \\
\hline Porte município & $\begin{array}{l}-0.0336 \\
(-1.16)\end{array}$ & $\begin{array}{l}-0.0192 \\
(-0.66)\end{array}$ & $\begin{array}{l}-0.0169 \\
(-0.58)\end{array}$ \\
\hline Constante & $\begin{array}{l}-0.465 \\
(-1.84)\end{array}$ & $\begin{array}{l}-0.540^{*} \\
(-2.12)\end{array}$ & $\begin{array}{l}-0.842^{* * *} \\
(-3.33)\end{array}$ \\
\hline Observações & 3077 & 3077 & 3077 \\
\hline
\end{tabular}

Estatística $t$ entre parênteses.

${ }^{\ddagger} p<0.10^{*} p<0.05,{ }^{* *} p<0.01,{ }^{* * *} p<0.001$

Nota: elaborado pelo autor a partir dos dados do Datafolha (2018). A variável dependente assume valor 1 se o indivíduo tinha intenção de votar no PT na véspera do segundo turno das eleições presidenciais de 2018 e 0 , caso contrário. 
Tabela 29 - Voto para presidente de acordo com o crescimento dos grupos religiosos (2010 e 2014)

\begin{tabular}{|c|c|c|c|c|c|c|}
\hline & $\begin{array}{c}(1) \\
\text { PT (2010) }\end{array}$ & $\begin{array}{c}(2) \\
\text { PT (2010) }\end{array}$ & $\begin{array}{c}(3) \\
\text { PT (2010) }\end{array}$ & $\begin{array}{c}(4) \\
\text { PT (2014) }\end{array}$ & $\begin{array}{c}(5) \\
\text { PT (2014) }\end{array}$ & $\begin{array}{c}(6) \\
\text { PT (2014) }\end{array}$ \\
\hline Pentecostais & $\begin{array}{l}-0.246 \\
(-0.58)\end{array}$ & & & $\begin{array}{l}-0.0757 \\
(-0.18)\end{array}$ & & \\
\hline Tradicionais & & $\begin{array}{l}0.548^{\ddagger} \\
(1.81)\end{array}$ & & & $\begin{array}{l}0.513^{\ddagger} \\
(1.71)\end{array}$ & \\
\hline Católicos & & & $\begin{array}{l}2.360^{* * *} \\
(4.46)\end{array}$ & & & $\begin{array}{l}2.471^{* * *} \\
(4.94)\end{array}$ \\
\hline Analfabetismo & $\begin{array}{l}0.324^{* * *} \\
(9.67)\end{array}$ & $\begin{array}{l}0.319^{* * *} \\
(9.49)\end{array}$ & $\begin{array}{l}0.326^{* * *} \\
(9.77)\end{array}$ & $\begin{array}{l}0.244^{* * *} \\
(8.34)\end{array}$ & $\begin{array}{l}0.240^{* * *} \\
(8.15)\end{array}$ & $\begin{array}{l}0.247^{* * *} \\
(8.44)\end{array}$ \\
\hline Pobreza & $\begin{array}{c}0.421^{* * *} \\
(11.49)\end{array}$ & $\begin{array}{c}0.422^{* * *} \\
(11.51)\end{array}$ & $\begin{array}{l}0.420^{* * *} \\
(11.53)\end{array}$ & $\begin{array}{c}0.515^{* * *} \\
(14.28)\end{array}$ & $\begin{array}{c}0.516^{* * *} \\
(14.30)\end{array}$ & $\begin{array}{c}0.514^{* * *} \\
(14.31)\end{array}$ \\
\hline Renda per capita & $\begin{array}{l}0.00352 \\
(1.79)\end{array}$ & $\begin{array}{l}0.00374 \\
(1.89)\end{array}$ & $\begin{array}{l}0.00288 \\
(1.48)\end{array}$ & $\begin{array}{l}-0.00146 \\
(-0.76)\end{array}$ & $\begin{array}{l}-0.00125 \\
(-0.65)\end{array}$ & $\begin{array}{l}-0.00212 \\
(-1.12)\end{array}$ \\
\hline Gini & $\begin{array}{l}-26.26^{* * *} \\
(-6.09)\end{array}$ & $\begin{array}{l}-26.19^{* * *} \\
(-6.07)\end{array}$ & $\begin{array}{l}-25.55^{* * *} \\
(-5.94)\end{array}$ & $\begin{array}{l}-13.24^{* *} \\
(-3.23)\end{array}$ & $\begin{array}{l}-13.19^{* *} \\
(-3.21)\end{array}$ & $\begin{array}{l}-12.51^{* *} \\
(-3.05)\end{array}$ \\
\hline Formalização & $\begin{array}{l}-0.127^{* * *} \\
(-7.78)\end{array}$ & $\begin{array}{l}-0.127^{* * *} \\
(-7.78)\end{array}$ & $\begin{array}{l}-0.122^{* * *} \\
(-7.48)\end{array}$ & $\begin{array}{l}-0.201^{* * *} \\
(-11.82)\end{array}$ & $\begin{array}{l}-0.201^{* * *} \\
(-11.83)\end{array}$ & $\begin{array}{l}-0.196^{* * *} \\
(-11.52)\end{array}$ \\
\hline Desocupação & $\begin{array}{l}-0.144^{*} \\
(-2.48)\end{array}$ & $\begin{array}{l}-0.146^{*} \\
(-2.53)\end{array}$ & $\begin{array}{l}-0.143^{*} \\
(-2.46)\end{array}$ & $\begin{array}{l}-0.232^{* * *} \\
(-4.18)\end{array}$ & $\begin{array}{l}-0.234^{* * *} \\
(-4.21)\end{array}$ & $\begin{array}{l}-0.230^{* * *} \\
(-4.18)\end{array}$ \\
\hline IDHM & $\begin{array}{l}10.14 \\
(1.28)\end{array}$ & $\begin{array}{c}9.702 \\
(1.23)\end{array}$ & $\begin{array}{l}12.88 \\
(1.64)\end{array}$ & $\begin{array}{l}20.95^{* *} \\
(2.88)\end{array}$ & $\begin{array}{l}20.53^{* *} \\
(2.82)\end{array}$ & $\begin{array}{l}23.83^{* *} \\
(3.28)\end{array}$ \\
\hline PBF (2010) & $\begin{array}{l}0.0000728^{* * *} \\
(4.15)\end{array}$ & $\begin{array}{l}0.0000721^{* * *} \\
(4.14)\end{array}$ & $\begin{array}{l}0.0000757^{* * *} \\
(4.24)\end{array}$ & & & \\
\hline PBF (2014) & & & & $\begin{array}{l}0.0000368^{*} \\
(2.01)\end{array}$ & $\begin{array}{l}0.0000367^{*} \\
(2.01)\end{array}$ & $\begin{array}{l}0.0000394^{*} \\
(2.10)\end{array}$ \\
\hline Região & $\begin{array}{l}0.848^{* * *} \\
(4.49)\end{array}$ & $\begin{array}{l}0.869^{* * *} \\
(4.59)\end{array}$ & $\begin{array}{l}0.805^{* * *} \\
(4.26)\end{array}$ & $\begin{array}{c}0.280 \\
(1.50)\end{array}$ & $\begin{array}{c}0.296 \\
(1.59)\end{array}$ & $\begin{array}{c}0.231 \\
(1.24)\end{array}$ \\
\hline Constante & $\begin{array}{l}39.70^{* * *} \\
(6.71)\end{array}$ & $\begin{array}{l}39.30^{* * *} \\
(6.65)\end{array}$ & $\begin{array}{l}37.32^{* * *} \\
(6.36)\end{array}$ & $\begin{array}{l}28.57^{* * *} \\
(5.23)\end{array}$ & $\begin{array}{l}28.33^{* * *} \\
(5.19)\end{array}$ & $\begin{array}{l}26.20^{* * *} \\
(4.81)\end{array}$ \\
\hline Observações & 5562 & 5562 & 5562 & 5562 & 5562 & 5562 \\
\hline
\end{tabular}

${ }^{\ddagger} p<0.10{ }^{*} p<0.05,{ }^{* *} p<0.01,{ }^{* * *} p<0.001$

Nota: elaborado pelo autor a partir dos dados do Instituto Brasileiro de Geografia e Estatística (IBGE) e do Tribunal Superior Eleitoral (TSE). A variável dependente é a proporção de votos válidos do PT nas eleições presidenciais de 2010 e 2014. 
Tabela 30 - Voto no PT nas eleições presidenciais de acordo com o crescimento dos grupos religiosos (2018)

\begin{tabular}{|c|c|c|c|}
\hline & $\begin{array}{c}(1) \\
\text { PT (2018) }\end{array}$ & $\begin{array}{c}(2) \\
\text { PT (2018) }\end{array}$ & $\begin{array}{c}(3) \\
\text { PT (2018) }\end{array}$ \\
\hline Pentecostais & $\begin{array}{c}-0.599 \\
(-1.44)\end{array}$ & & \\
\hline Tradicionais & & $\begin{array}{l}0.897^{* *} \\
(3.06)\end{array}$ & \\
\hline Católicos & & & $\begin{array}{l}2.401^{* * *} \\
(4.82)\end{array}$ \\
\hline Analfabetismo & $\begin{array}{l}0.333^{* * *} \\
(9.97)\end{array}$ & $\begin{array}{l}0.323^{\text {*** }} \\
(9.67)\end{array}$ & $\begin{array}{l}0.334^{* * *} \\
(10.02)\end{array}$ \\
\hline Pobreza & $\begin{array}{c}0.576^{* * *} \\
(16.15)\end{array}$ & $\begin{array}{c}0.578^{* * *} \\
(16.21)\end{array}$ & $\begin{array}{c}0.576^{* * *} \\
(16.15)\end{array}$ \\
\hline Renda per capita & $\begin{array}{l}0.00767^{* * *} \\
(4.97)\end{array}$ & $\begin{array}{l}0.00802^{* * *} \\
(5.17)\end{array}$ & $\begin{array}{l}0.00701^{* * *} \\
(4.55)\end{array}$ \\
\hline Gini & $\begin{array}{l}-14.13^{* * *} \\
(-3.52)\end{array}$ & $\begin{array}{l}-13.99^{* * *} \\
(-3.50)\end{array}$ & $\begin{array}{l}-13.36^{* * *} \\
(-3.33)\end{array}$ \\
\hline Formalização & $\begin{array}{l}-0.0901^{* * *} \\
(-5.69)\end{array}$ & $\begin{array}{l}-0.0906^{* * *} \\
(-5.72)\end{array}$ & $\begin{array}{l}-0.0860^{* * *} \\
(-5.42)\end{array}$ \\
\hline Desocupação & $\begin{array}{l}0.242^{* * *} \\
(4.04)\end{array}$ & $\begin{array}{l}0.238^{* * *} \\
(4.00)\end{array}$ & $\begin{array}{l}0.242^{* * *} \\
(4.07)\end{array}$ \\
\hline IDHM & $\begin{array}{l}-50.42^{* * *} \\
(-6.44)\end{array}$ & $\begin{array}{l}-51.14^{* * *} \\
(-6.53)\end{array}$ & $\begin{array}{l}-47.61^{* * *} \\
(-6.06)\end{array}$ \\
\hline PBF (2018) & $\begin{array}{l}-6.09 e-08 \\
(-0.00)\end{array}$ & $\begin{array}{l}-0.00000113 \\
(-0.08)\end{array}$ & $\begin{array}{l}0.00000150 \\
(0.10)\end{array}$ \\
\hline Região & $\begin{array}{l}0.954^{* * *} \\
(5.47)\end{array}$ & $\begin{array}{l}0.991^{* * *} \\
(5.67)\end{array}$ & $\begin{array}{l}0.916^{* * *} \\
(5.25)\end{array}$ \\
\hline Constante & $\begin{array}{l}46.64^{* * *} \\
(7.98)\end{array}$ & $\begin{array}{l}45.84^{* * *} \\
(7.86)\end{array}$ & $\begin{array}{l}43.92^{* * *} \\
(7.51)\end{array}$ \\
\hline Observações & 5562 & 5562 & 5562 \\
\hline
\end{tabular}

Nota: elaborado pelo autor a partir dos dados do Instituto Brasileiro de Geografia e Estatística (IBGE) e do Tribunal Superior Eleitoral (TSE). A variável dependente é a proporção de votos válidos do PT nas eleições presidenciais de 2018. 
Tabela 31 - Transição religiosa e voto no PT nas eleições presidenciais (2010-2018) Municípios com maioria evangélica pentecostal

\begin{tabular}{lccc}
\hline \hline & $(1)$ & $(2)$ & $(3)$ \\
& PT (2010) & PT (2014) & PT (2018) \\
\hline ATET & & & \\
Pentecostais & & & \\
& $-7.201^{*}$ & $-7.490^{*}$ & $-14.58^{* * *}$ \\
\hline Tratados & $(-1.97)$ & $(-2.48)$ & $(-6.54)$ \\
Controle & 22 & 22 & 22 \\
N. Matching & 22 & 22 & 22 \\
N. Total & 44 & 44 & 44 \\
\hline \hline
\end{tabular}

Estatística $t$ entre parênteses.

${ }^{\ddagger} p<0.10^{*} p<0.05,{ }^{* *} p<0.01,{ }^{* * *} p<0.001$

Nota: elaborado pelo autor a partir dos dados do Instituto Brasileiro de Geografia e Estatística (IBGE) e do Tribunal Superior Eleitoral (TSE). A variável dependente é a proporção de votos válidos do PT nas eleições presidenciais (2010-2014).

Tabela 32 - Transição religiosa e voto no PT nas eleições presidenciais (2010-2018) Municípios com maioria evangélica tradicional

\begin{tabular}{lccc}
\hline \hline & $(1)$ & $(2)$ & $(3)$ \\
& PT (2010) & PT (2014) & PT (2018) \\
\hline ATET & & & \\
Tradicionais & & & \\
& $-6.136^{*}$ & -2.911 & -3.734 \\
Tratados & $(-2.07)$ & $(-0.87)$ & $(-1.42)$ \\
Controle & 27 & 27 & 27 \\
N. Matching & 27 & 27 & 27 \\
N. Total & 54 & 54 & 54 \\
\hline \hline
\end{tabular}

Estatística $t$ entre parênteses.

${ }^{\ddagger} p<0.10^{*} p<0.05,{ }^{* *} p<0.01,{ }^{* * *} p<0.001$

Nota: elaborado pelo autor a partir dos dados do Instituto Brasileiro de Geografia e Estatística (IBGE) e do Tribunal Superior Eleitoral (TSE). A variável dependente é a proporção de votos válidos do PT nas eleições presidenciais (2010-2014). 
Tabela 33 - Voto no PT nas eleições presidenciais por filiação religiosa - eleição placebo (2002)

\begin{tabular}{|c|c|c|c|}
\hline & $\begin{array}{c}(1) \\
\text { PT (2002) }\end{array}$ & $\begin{array}{c}(2) \\
\text { PT (2002) }\end{array}$ & $\begin{array}{c}(3) \\
\text { PT (2002) }\end{array}$ \\
\hline Pentecostais & $\begin{array}{l}-0.373^{* * *} \\
(-13.60)\end{array}$ & & \\
\hline Tradicionais & & $\begin{array}{l}-0.0933^{* * *} \\
(-3.38)\end{array}$ & \\
\hline Católicos & & & $\begin{array}{l}0.171^{\text {*** }} \\
(11.45)\end{array}$ \\
\hline Analfabetismo & $\begin{array}{c}-0.459^{* * *} \\
(-16.40)\end{array}$ & $\begin{array}{c}-0.392^{* * *} \\
(-14.12)\end{array}$ & $\begin{array}{l}-0.446^{\text {*** }} \\
(-15.93)\end{array}$ \\
\hline Pobreza & $\begin{array}{l}0.153^{* * *} \\
(4.95)\end{array}$ & $\begin{array}{l}0.143^{\text {*** }} \\
(4.59)\end{array}$ & $\begin{array}{l}0.130^{* * *} \\
(4.20)\end{array}$ \\
\hline Renda per capita & $\begin{array}{l}-0.00376 \\
(-1.48)\end{array}$ & $\begin{array}{l}-0.00531^{*} \\
(-2.07)\end{array}$ & $\begin{array}{l}-0.00296 \\
(-1.15)\end{array}$ \\
\hline Gini & $\begin{array}{l}-4.138 \\
(-1.27)\end{array}$ & $\begin{array}{l}-5.416 \\
(-1.65)\end{array}$ & $\begin{array}{l}-4.755 \\
(-1.45)\end{array}$ \\
\hline Formalização & $\begin{array}{l}0.113^{* * *} \\
(7.16)\end{array}$ & $\begin{array}{l}0.0997^{\text {*** }} \\
(6.24)\end{array}$ & $\begin{array}{l}0.107^{* * *} \\
(6.82)\end{array}$ \\
\hline Desocupação & $\begin{array}{l}0.128^{* * *} \\
(3.77)\end{array}$ & $\begin{array}{l}0.0347 \\
(1.05)\end{array}$ & $\begin{array}{l}0.143^{\text {*** }} \\
(4.07)\end{array}$ \\
\hline IDHM & $\begin{array}{r}8.420 \\
(1.91)\end{array}$ & $\begin{array}{l}16.14^{\text {*** }} \\
(3.70)\end{array}$ & $\begin{array}{c}5.886 \\
(1.33)\end{array}$ \\
\hline Região & $\begin{array}{l}-0.312^{*} \\
(-2.10)\end{array}$ & $\begin{array}{l}-0.338^{*} \\
(-2.21)\end{array}$ & $\begin{array}{l}-0.339^{*} \\
(-2.24)\end{array}$ \\
\hline Constante & $\begin{array}{l}41.38^{* * *} \\
(11.95)\end{array}$ & $\begin{array}{l}36.32^{\text {*** }} \\
(10.62)\end{array}$ & $\begin{array}{l}26.98^{* * *} \\
(7.91)\end{array}$ \\
\hline Observações & 5507 & 5507 & 5507 \\
\hline
\end{tabular}

Estatística $t$ entre parênteses.

${ }^{\ddagger} p<0.10^{*} p<0.05,{ }^{* *} p<0.01,{ }^{* * *} p<0.001$

Nota: elaborado pelo autor a partir dos dados do Instituto Brasileiro de Geografia e Estatística (IBGE) e do Tribunal Superior Eleitoral (TSE). A variável dependente é a proporção de votos válidos do PT nas eleições presidenciais de 2002. 
Tabela 34 - Preferência por redistribuição por filiação religiosa (2014)

\begin{tabular}{|c|c|c|c|}
\hline & $\begin{array}{c}(1) \\
\text { Redistribuição }\end{array}$ & $\begin{array}{c}(2) \\
\text { Redistribuição }\end{array}$ & $\begin{array}{c}(3) \\
\text { Redistribuição }\end{array}$ \\
\hline Pentecostais & $\begin{array}{l}-0.110 \\
(-0.95)\end{array}$ & & \\
\hline Tradicionais & & $\begin{array}{c}0.242 \\
(0.94)\end{array}$ & \\
\hline Católicos & & & $\begin{array}{l}0.161^{\ddagger} \\
(1.70)\end{array}$ \\
\hline Idade & $\begin{array}{l}-0.00178 \\
(-0.52)\end{array}$ & $\begin{array}{l}-0.00161 \\
(-0.47)\end{array}$ & $\begin{array}{l}-0.00211 \\
(-0.61)\end{array}$ \\
\hline Gênero & $\begin{array}{l}-0.0160 \\
(-0.18)\end{array}$ & $\begin{array}{l}-0.0257 \\
(-0.28)\end{array}$ & $\begin{array}{l}-0.0160 \\
(-0.18)\end{array}$ \\
\hline Escolaridade & $\begin{array}{l}0.0173 \\
(0.76)\end{array}$ & $\begin{array}{l}0.0180 \\
(0.79)\end{array}$ & $\begin{array}{l}0.0193 \\
(0.85)\end{array}$ \\
\hline Renda & $\begin{array}{l}0.00366 \\
(0.10)\end{array}$ & $\begin{array}{l}0.00309 \\
(0.09)\end{array}$ & $\begin{array}{l}0.00303 \\
(0.09)\end{array}$ \\
\hline Raça & $\begin{array}{l}-0.0157 \\
(-0.24)\end{array}$ & $\begin{array}{l}-0.0108 \\
(-0.17)\end{array}$ & $\begin{array}{l}-0.0205 \\
(-0.32)\end{array}$ \\
\hline Ocupação & $\begin{array}{r}0.402 \\
(1.31)\end{array}$ & $\begin{array}{c}0.404 \\
(1.32)\end{array}$ & $\begin{array}{r}0.408 \\
(1.32)\end{array}$ \\
\hline Percep. economia & $\begin{array}{l}0.246^{*} \\
(2.41)\end{array}$ & $\begin{array}{l}0.251^{*} \\
(2.45)\end{array}$ & $\begin{array}{l}0.237^{*} \\
(2.31)\end{array}$ \\
\hline Gov. avaliação & $\begin{array}{l}-0.0414 \\
(-0.42)\end{array}$ & $\begin{array}{l}-0.0385 \\
(-0.39)\end{array}$ & $\begin{array}{l}-0.0467 \\
(-0.47)\end{array}$ \\
\hline PBF & $\begin{array}{l}-0.164 \\
(-1.53)\end{array}$ & $\begin{array}{l}-0.169 \\
(-1.57)\end{array}$ & $\begin{array}{l}-0.167 \\
(-1.55)\end{array}$ \\
\hline Região & $\begin{array}{l}-0.0886 \\
(-1.73)\end{array}$ & $\begin{array}{l}-0.0909 \\
(-1.77)\end{array}$ & $\begin{array}{l}-0.0847 \\
(-1.65)\end{array}$ \\
\hline Constante & $\begin{array}{l}1.605^{* * *} \\
(4.49)\end{array}$ & $\begin{array}{l}1.574^{* * *} \\
(4.42)\end{array}$ & $\begin{array}{l}1.502^{* * *} \\
(4.18)\end{array}$ \\
\hline Observações & 3049 & 3049 & 3049 \\
\hline
\end{tabular}

Estatística $t$ entre parênteses.

${ }^{\ddagger} p<0.10^{*} p<0.05,{ }^{* *} p<0.01,{ }^{* * *} p<0.001$

Nota: elaborado pelo autor a partir dos dados do Estudo Eleitoral Brasileiro (ESEB, 2014). A variável dependente assume valor 1 se o indivíduo concorda com a afirmação de que o governo deveria tomar medidas para reduzir as diferenças entre os níveis de renda e 0 , caso contrário. 
Tabela 35 - Efeitos de vizinhança da variável religião sobre a votação do PT (2006)

\begin{tabular}{|c|c|c|c|}
\hline & $\begin{array}{c}(1) \\
\text { PT (2006) }\end{array}$ & $\begin{array}{c}(2) \\
\text { PT (2006) }\end{array}$ & $\begin{array}{c}(3) \\
\text { PT (2006) }\end{array}$ \\
\hline Pentecostais & $\begin{array}{l}-0.0279 \\
(-1.08)\end{array}$ & & \\
\hline Tradicionais & & $\begin{array}{l}0.102^{* * *} \\
(3.64)\end{array}$ & \\
\hline Católicos & & & $\begin{array}{l}-0.00233 \\
(-0.18)\end{array}$ \\
\hline Gini & $\begin{array}{l}-15.74^{* * *} \\
(-5.32)\end{array}$ & $\begin{array}{l}-17.15^{* * *} \\
(-5.78)\end{array}$ & $\begin{array}{l}-16.43^{* * *} \\
(-5.50)\end{array}$ \\
\hline Analfabetismo & $\begin{array}{l}0.141^{* * *} \\
(4.01)\end{array}$ & $\begin{array}{l}0.181^{* * *} \\
(5.16)\end{array}$ & $\begin{array}{l}0.161^{* * *} \\
(4.55)\end{array}$ \\
\hline Pobreza & $\begin{array}{c}0.566^{* * *} \\
(21.73)\end{array}$ & $\begin{array}{l}0.567^{* * *} \\
(21.78)\end{array}$ & $\begin{array}{l}0.560^{\text {*** }} \\
(21.57)\end{array}$ \\
\hline IDHM & $\begin{array}{l}47.15^{* * *} \\
(6.56)\end{array}$ & $\begin{array}{l}51.01^{* * *} \\
(7.08)\end{array}$ & $\begin{array}{l}49.14^{* * *} \\
(6.79)\end{array}$ \\
\hline Formalização & $\begin{array}{l}0.0244 \\
(1.52)\end{array}$ & $\begin{array}{c}0.0273 \\
(1.71)\end{array}$ & $\begin{array}{l}0.0232 \\
(1.45)\end{array}$ \\
\hline Urbanização & $\begin{array}{l}-10.10^{* * *} \\
(-10.70)\end{array}$ & $\begin{array}{l}-9.733^{* * *} \\
(-10.52)\end{array}$ & $\begin{array}{l}-9.396^{* * *} \\
(-9.86)\end{array}$ \\
\hline PBF (2006) & $\begin{array}{l}1.122^{* * *} \\
(16.73)\end{array}$ & $\begin{array}{l}1.174^{* * *} \\
(17.69)\end{array}$ & $\begin{array}{l}1.160^{* * *} \\
(17.26)\end{array}$ \\
\hline Constante & $\begin{array}{l}-5.009 \\
(-0.90)\end{array}$ & $\begin{array}{l}-10.63 \\
(-1.90)\end{array}$ & $\begin{array}{l}-9.087 \\
(-1.64)\end{array}$ \\
\hline $\begin{array}{l}\text { W } \\
\text { Pentecostais }\end{array}$ & $\begin{array}{l}-0.173^{* * *} \\
(-5.03)\end{array}$ & & \\
\hline Tradicionais & & $\begin{array}{l}0.0301 \\
(0.48)\end{array}$ & \\
\hline Católicos & & & $\begin{array}{l}0.0133^{*} \\
(2.07)\end{array}$ \\
\hline Observações & 5561 & 5561 & 5561 \\
\hline
\end{tabular}

Nota: elaborado pelo autor a partir dos dados do Instituto Brasileiro de Geografia e Estatística (IBGE) e do Tribunal Superior Eleitoral (TSE). A variável dependente é a proporção de votos válidos do PT nas eleições presidenciais de 2006. 
Tabela 36 - Efeitos de vizinhança da variável religião sobre a votação do PT (2010)

\begin{tabular}{|c|c|c|c|}
\hline & $\begin{array}{c}(1) \\
\text { PT (2010) }\end{array}$ & $\begin{array}{c}(2) \\
\text { PT (2010) }\end{array}$ & $\begin{array}{c}\text { (3) } \\
\text { PT (2010) }\end{array}$ \\
\hline Pentecostais & $\begin{array}{l}-0.333^{* * *} \\
(-14.01)\end{array}$ & & \\
\hline Tradicionais & & $\begin{array}{l}0.0113 \\
(0.42)\end{array}$ & \\
\hline Católicos & & & $\begin{array}{l}0.178^{* * *} \\
(15.21)\end{array}$ \\
\hline Gini & $\begin{array}{l}-9.356^{* * *} \\
(-3.44)\end{array}$ & $\begin{array}{l}-13.56^{* * *} \\
(-4.86)\end{array}$ & $\begin{array}{l}-5.608^{*} \\
(-2.03)\end{array}$ \\
\hline Analfabetismo & $\begin{array}{l}0.0193 \\
(0.59)\end{array}$ & $\begin{array}{l}0.162^{* * *} \\
(4.90)\end{array}$ & $\begin{array}{l}0.0109 \\
(0.33)\end{array}$ \\
\hline Pobreza & $\begin{array}{l}0.198^{* * *} \\
(8.01)\end{array}$ & $\begin{array}{l}0.167^{\text {*** }} \\
(6.60)\end{array}$ & $\begin{array}{l}0.168^{* * *} \\
(6.81)\end{array}$ \\
\hline IDHM & $\begin{array}{c}2.431 \\
(0.37)\end{array}$ & $\begin{array}{l}17.70^{* *} \\
(2.63)\end{array}$ & $\begin{array}{l}-1.082 \\
(-0.16)\end{array}$ \\
\hline Formalização & $\begin{array}{l}-0.0130 \\
(-0.87)\end{array}$ & $\begin{array}{l}-0.0303^{*} \\
(-1.99)\end{array}$ & $\begin{array}{l}-0.00641 \\
(-0.43)\end{array}$ \\
\hline Urbanização & $\begin{array}{l}6.825^{* * *} \\
(7.82)\end{array}$ & $\begin{array}{l}9.928^{* * *} \\
(11.31)\end{array}$ & $\begin{array}{l}6.641^{* * *} \\
(7.53)\end{array}$ \\
\hline PBF (2010) & $\begin{array}{l}1.274^{* * *} \\
(17.18)\end{array}$ & $\begin{array}{l}1.362^{* * *} \\
(17.99)\end{array}$ & $\begin{array}{l}1.343^{* * *} \\
(18.08)\end{array}$ \\
\hline Constante & $\begin{array}{l}40.48^{* * *} \\
(7.87)\end{array}$ & $\begin{array}{l}24.37^{* * *} \\
(4.63)\end{array}$ & $\begin{array}{l}21.97^{* * *} \\
(4.31)\end{array}$ \\
\hline $\begin{array}{l}\text { W } \\
\text { Pentecostais }\end{array}$ & $\begin{array}{l}-0.183^{* * *} \\
(-5.77)\end{array}$ & & \\
\hline Tradicionais & & $\begin{array}{l}0.149^{*} \\
(2.53)\end{array}$ & \\
\hline Católicos & & & $\begin{array}{l}0.0134^{*} \\
(2.26)\end{array}$ \\
\hline Observações & 5561 & 5561 & 5561 \\
\hline
\end{tabular}

Nota: elaborado pelo autor a partir dos dados do Instituto Brasileiro de Geografia e Estatística (IBGE) e do Tribunal Superior Eleitoral (TSE). A variável dependente é a proporção de votos válidos do PT nas eleições presidenciais de 2010. 
Tabela 37 - Efeitos de vizinhança da variável religião sobre a votação do PT (2014)

\begin{tabular}{|c|c|c|c|}
\hline & $\begin{array}{c}(1) \\
\text { PT (2014) }\end{array}$ & $\begin{array}{c}(2) \\
\text { PT (2014) }\end{array}$ & $\begin{array}{c}\text { (3) } \\
\text { PT (2014) }\end{array}$ \\
\hline Pentecostais & $\begin{array}{l}-0.392^{* * *} \\
(-16.89)\end{array}$ & & \\
\hline Tradicionais & & $\begin{array}{l}0.0402 \\
(1.53)\end{array}$ & \\
\hline Católicos & & & $\begin{array}{l}0.204^{* * *} \\
(17.76)\end{array}$ \\
\hline Gini & $\begin{array}{l}-4.950 \\
(-1.87)\end{array}$ & $\begin{array}{l}-10.76^{* * *} \\
(-3.94)\end{array}$ & $\begin{array}{l}-0.687 \\
(-0.26)\end{array}$ \\
\hline Analfabetismo & $\begin{array}{l}-0.0512 \\
(-1.64)\end{array}$ & $\begin{array}{l}0.138^{* * *} \\
(4.32)\end{array}$ & $\begin{array}{l}-0.0609 \\
(-1.92)\end{array}$ \\
\hline Pobreza & $\begin{array}{l}0.282^{* * *} \\
(10.64)\end{array}$ & $\begin{array}{l}0.249^{* * *} \\
(9.06)\end{array}$ & $\begin{array}{l}0.233^{* * *} \\
(8.77)\end{array}$ \\
\hline IDHM & $\begin{array}{c}6.373 \\
(1.00)\end{array}$ & $\begin{array}{l}26.65^{* * *} \\
(4.04)\end{array}$ & $\begin{array}{c}2.632 \\
(0.41)\end{array}$ \\
\hline Formalização & $\begin{array}{l}-0.104^{* * *} \\
(-7.15)\end{array}$ & $\begin{array}{l}-0.124^{* * *} \\
(-8.27)\end{array}$ & $\begin{array}{l}-0.0961^{* * *} \\
(-6.54)\end{array}$ \\
\hline Urbanização & $\begin{array}{l}5.907^{* * *} \\
(6.89)\end{array}$ & $\begin{array}{l}9.383^{* * *} \\
(10.78)\end{array}$ & $\begin{array}{l}5.933^{* * *} \\
(6.84)\end{array}$ \\
\hline PBF (2014) & $\begin{array}{l}1.189^{* * *} \\
(16.39)\end{array}$ & $\begin{array}{l}1.283^{* * *} \\
(17.13)\end{array}$ & $\begin{array}{l}1.309^{* * *} \\
(17.94)\end{array}$ \\
\hline Constante & $\begin{array}{l}35.79^{* * *} \\
(7.13)\end{array}$ & $\begin{array}{l}14.77^{* *} \\
(2.85)\end{array}$ & $\begin{array}{l}13.84^{* *} \\
(2.77)\end{array}$ \\
\hline $\begin{array}{l}\text { W } \\
\text { Pentecostais }\end{array}$ & $\begin{array}{l}-0.227^{* * *} \\
(-7.33)\end{array}$ & & \\
\hline Tradicionais & & $\begin{array}{l}0.293^{* * *} \\
(5.04)\end{array}$ & \\
\hline Católicos & & & $\begin{array}{l}0.0216^{* * *} \\
(3.70)\end{array}$ \\
\hline Observações & 5561 & 5561 & 5561 \\
\hline
\end{tabular}

Nota: elaborado pelo autor a partir dos dados do Instituto Brasileiro de Geografia e Estatística (IBGE) e do Tribunal Superior Eleitoral (TSE). A variável dependente é a proporção de votos válidos do PT nas eleições presidenciais de 2014. 
Tabela 38 - Efeitos de vizinhança da variável religião sobre a votação do PT (2018)

\begin{tabular}{|c|c|c|c|}
\hline & $\begin{array}{c}(1) \\
\text { PT }(2018)\end{array}$ & $\begin{array}{c}(2) \\
\text { PT }(2018)\end{array}$ & $\begin{array}{c}(3) \\
\text { PT (2018) }\end{array}$ \\
\hline Pentecostais & $\begin{array}{l}-0.357^{* * *} \\
(-15.32)\end{array}$ & & \\
\hline Tradicionais & & $\begin{array}{l}-0.0661^{*} \\
(-2.52)\end{array}$ & \\
\hline Católicos & & & $\begin{array}{l}0.177^{* * *} \\
(15.41)\end{array}$ \\
\hline Gini & $\begin{array}{c}4.022 \\
(1.52)\end{array}$ & $\begin{array}{c}0.175 \\
(0.06)\end{array}$ & $\begin{array}{l}7.603^{* *} \\
(2.82)\end{array}$ \\
\hline Analfabetismo & $\begin{array}{l}0.0408 \\
(1.30)\end{array}$ & $\begin{array}{l}0.176^{* * *} \\
(5.55)\end{array}$ & $\begin{array}{l}0.0360 \\
(1.13)\end{array}$ \\
\hline Pobreza & $\begin{array}{l}0.262^{* * *} \\
(9.85)\end{array}$ & $\begin{array}{l}0.219^{* * *} \\
(8.05)\end{array}$ & $\begin{array}{l}0.217^{* * *} \\
(8.18)\end{array}$ \\
\hline IDHM & $\begin{array}{l}-53.42^{* * *} \\
(-8.34)\end{array}$ & $\begin{array}{l}-39.14^{* * *} \\
(-5.96)\end{array}$ & $\begin{array}{l}-56.46^{* * *} \\
(-8.72)\end{array}$ \\
\hline Formalização & $\begin{array}{l}0.0477^{* *} \\
(3.27)\end{array}$ & $\begin{array}{l}0.0262 \\
(1.76)\end{array}$ & $\begin{array}{l}0.0542^{* * *} \\
(3.68)\end{array}$ \\
\hline Urbanização & $\begin{array}{l}4.369^{* * *} \\
(5.08)\end{array}$ & $\begin{array}{l}7.836^{* * *} \\
(9.05)\end{array}$ & $\begin{array}{l}4.405^{* * *} \\
(5.07)\end{array}$ \\
\hline PBF (2018) & $\begin{array}{c}1.433^{* * *} \\
(19.69)\end{array}$ & $\begin{array}{l}1.505^{* * *} \\
(20.22)\end{array}$ & $\begin{array}{l}1.537^{* * *} \\
(21.04)\end{array}$ \\
\hline Constante & $\begin{array}{l}48.74^{* * *} \\
(9.68)\end{array}$ & $\begin{array}{l}34.49^{* * *} \\
(6.69)\end{array}$ & $\begin{array}{l}30.99^{* * *} \\
(6.20)\end{array}$ \\
\hline \multicolumn{4}{|l|}{ W } \\
\hline Pentecostais & $\begin{array}{l}-0.126^{* * *} \\
(-4.04)\end{array}$ & & \\
\hline Tradicionais & & $\begin{array}{l}0.128^{*} \\
(2.22)\end{array}$ & \\
\hline Católicos & & & $\begin{array}{l}0.00400 \\
(0.69)\end{array}$ \\
\hline Observações & 5561 & 5561 & 5561 \\
\hline
\end{tabular}

Nota: elaborado pelo autor a partir dos dados do Instituto Brasileiro de Geografia e Estatística (IBGE) e do Tribunal Superior Eleitoral (TSE). A variável dependente é a proporção de votos válidos do PT nas eleições presidenciais de 2018. 
Tabela 39 - Votação do PT nas eleições presidenciais entre os membros da IURD (2010 e 2014)

\begin{tabular}{|c|c|c|}
\hline & $\begin{array}{c}(1) \\
\text { PT (2010) }\end{array}$ & $\begin{array}{c}(2) \\
\text { PT (2014) }\end{array}$ \\
\hline IURD & $\begin{array}{c}0.142 \\
(0.43)\end{array}$ & $\begin{array}{l}-0.00301 \\
(-0.01)\end{array}$ \\
\hline Idade & $\begin{array}{l}0.0192^{\text {*** }} \\
(6.72)\end{array}$ & $\begin{array}{l}-0.00447 \\
(-1.44)\end{array}$ \\
\hline Gênero & $\begin{array}{l}-0.101 \\
(-1.30)\end{array}$ & $\begin{array}{l}0.0605 \\
(0.72)\end{array}$ \\
\hline Escolaridade & $\begin{array}{l}0.0396^{*} \\
(2.03)\end{array}$ & $\begin{array}{l}-0.0670^{* *} \\
(-3.07)\end{array}$ \\
\hline Renda & $\begin{array}{l}0.0774^{*} \\
(2.57)\end{array}$ & $\begin{array}{l}0.0805^{*} \\
(2.47)\end{array}$ \\
\hline Raça & $\begin{array}{c}-0.122^{*} \\
(-2.27)\end{array}$ & $\begin{array}{l}-0.156^{* *} \\
(-2.67)\end{array}$ \\
\hline Desempregado & $\begin{array}{c}-0.280 \\
(-1.29)\end{array}$ & $\begin{array}{l}-0.0280 \\
(-0.11)\end{array}$ \\
\hline Percep. Economia & $\begin{array}{c}0.0435 \\
(0.50)\end{array}$ & $\begin{array}{l}0.520^{* * *} \\
(5.40)\end{array}$ \\
\hline Gov. Avaliação & $\begin{array}{c}1.266^{* * *} \\
(15.49)\end{array}$ & $\begin{array}{c}1.862^{* * *} \\
(21.56)\end{array}$ \\
\hline PBF. Beneficiário & $\begin{array}{l}0.309^{* * *} \\
(3.34)\end{array}$ & $\begin{array}{l}0.367^{* * *} \\
(3.63)\end{array}$ \\
\hline Região & $\begin{array}{l}-0.0999^{*} \\
(-2.20)\end{array}$ & $\begin{array}{l}-0.239^{* * *} \\
(-4.68)\end{array}$ \\
\hline Constante & $\begin{array}{l}-1.183^{* * *} \\
(-3.87)\end{array}$ & $\begin{array}{c}-0.199 \\
(-0.59)\end{array}$ \\
\hline Observações & 3049 & 3049 \\
\hline
\end{tabular}

Nota: elaborado pelo autor a partir dos dados do Estudo Eleitoral Brasileiro (ESEB, 2014). A variável dependente assume valor 1 se o indivíduo votou no PT nas eleições de 2010 e 2014 e 0, caso contrário. 
Tabela 40 - Percepção moral dos indivíduos antes (2002) e depois (2004) da conversão ao pentecostalismo

(1) (2) (3) (4)

Honestidade Honestidade Lula (honesto) Lula (honesto)

\begin{tabular}{|c|c|c|c|c|}
\hline Antes da conversão & $\begin{array}{l}-0.292 \\
(-0.77)\end{array}$ & & $\begin{array}{l}0.902^{*} \\
(2.28)\end{array}$ & \\
\hline Depois da conversão & & $\begin{array}{l}1.025^{\ddagger} \\
(1.92)\end{array}$ & & $\begin{array}{c}0.229 \\
(0.43)\end{array}$ \\
\hline Raça & $\begin{array}{l}-0.0513 \\
(-0.34)\end{array}$ & $\begin{array}{l}0.0923 \\
(0.57)\end{array}$ & $\begin{array}{l}0.0886 \\
(0.62)\end{array}$ & $\begin{array}{l}-0.357^{*} \\
(-2.04)\end{array}$ \\
\hline Percep. Economia (país) & $\begin{array}{c}-0.280 \\
(-1.42)\end{array}$ & $\begin{array}{r}0.372 \\
(1.96)\end{array}$ & $\begin{array}{c}0.149 \\
(0.76)\end{array}$ & $\begin{array}{l}0.961^{* * *} \\
(4.32)\end{array}$ \\
\hline Percep. Economia (indivíduo) & $\begin{array}{c}-0.104 \\
(-0.59)\end{array}$ & $\begin{array}{l}0.0263 \\
(0.15)\end{array}$ & $\begin{array}{r}0.179 \\
(1.04)\end{array}$ & $\begin{array}{l}-0.144 \\
(-0.75)\end{array}$ \\
\hline Idade & $\begin{array}{c}0.219^{*} \\
(2.56)\end{array}$ & $\begin{array}{l}0.326^{* *} \\
(3.14)\end{array}$ & $\begin{array}{l}0.211^{* *} \\
(2.65)\end{array}$ & $\begin{array}{l}0.457^{* * *} \\
(4.03)\end{array}$ \\
\hline Escolaridade & $\begin{array}{l}-0.00619 \\
(-0.26)\end{array}$ & $\begin{array}{l}0.0265 \\
(1.02)\end{array}$ & $\begin{array}{l}0.0501^{*} \\
(2.24)\end{array}$ & $\begin{array}{l}0.102^{* * *} \\
(3.61)\end{array}$ \\
\hline Desemprego & $\begin{array}{l}-0.0485 \\
(-0.33)\end{array}$ & $\begin{array}{l}-0.395^{*} \\
(-2.41)\end{array}$ & $\begin{array}{l}-0.113 \\
(-0.81)\end{array}$ & $\begin{array}{c}0.149 \\
(0.83)\end{array}$ \\
\hline Freq. Igreja & $\begin{array}{r}0.159 \\
(0.93)\end{array}$ & $\begin{array}{l}-0.0496 \\
(-0.26)\end{array}$ & $\begin{array}{l}-0.0324 \\
(-0.20)\end{array}$ & $\begin{array}{r}0.156 \\
(0.79)\end{array}$ \\
\hline Nível de politização & $\begin{array}{r}0.107 \\
(0.70)\end{array}$ & $\begin{array}{l}0.0894 \\
(0.51)\end{array}$ & $\begin{array}{l}0.408^{* *} \\
(2.79)\end{array}$ & $\begin{array}{l}0.583^{* *} \\
(3.25)\end{array}$ \\
\hline Nível de sociabilidade & $\begin{array}{l}-0.0623 \\
(-0.37)\end{array}$ & $\begin{array}{l}0.0975 \\
(0.52)\end{array}$ & $\begin{array}{l}-0.0172 \\
(-0.10)\end{array}$ & $\begin{array}{l}-0.0727 \\
(-0.38)\end{array}$ \\
\hline Pref. Partido & $\begin{array}{c}0.189 \\
(1.32)\end{array}$ & $\begin{array}{l}-0.131 \\
(-0.81)\end{array}$ & $\begin{array}{l}1.486^{* * *} \\
(10.70)\end{array}$ & $\begin{array}{l}1.296^{* * *} \\
(6.77)\end{array}$ \\
\hline Constante & $\begin{array}{r}0.518 \\
(1.56)\end{array}$ & $\begin{array}{l}0.0406 \\
(0.09)\end{array}$ & $\begin{array}{l}-1.548^{* * *} \\
(-4.71)\end{array}$ & $\begin{array}{l}-1.771^{* * *} \\
(-3.59)\end{array}$ \\
\hline Observações & 1092 & 928 & 1081 & 930 \\
\hline
\end{tabular}

Estatística $t$ entre parênteses.

${ }^{\ddagger} p<0.10^{*} p<0.05,{ }^{* *} p<0.01,{ }^{* * *} p<0.001$

Nota: Elaborado pelo autor a partir dos dados da pesquisa Two-City Brazilian Panel Study Dataset (BAKER; AMES; RENNO, 2006). Nos modelos 1 e 2, a variável dependente assume valor 1 caso o indivíduo prefira um candidato que seja honesto, mesmo que incompetente, e 0 caso contrário. Nos modelos 3 e 4 , a variável dependente assume o valor 1 caso o indivíduo considere o político Lula "muito honesto"ou "honesto", e 0 caso contrário. 
Tabela 41 - Efeito do PBF sobre a votação do PT por filiação religiosa - nível municipal (2006)

\begin{tabular}{|c|c|c|c|c|}
\hline & $\begin{array}{c}(1) \\
\text { PT (2006) }\end{array}$ & $\begin{array}{c}(2) \\
\text { PT (2006) }\end{array}$ & $\begin{array}{c}(3) \\
\text { PT (2006) }\end{array}$ & $\begin{array}{c}(4) \\
\text { PT (2006) }\end{array}$ \\
\hline PBF X PENT & $\begin{array}{l}0.000410 \\
(0.14)\end{array}$ & & & \\
\hline PBF X TRAD & & $\begin{array}{l}0.0119^{*} \\
(2.52)\end{array}$ & & \\
\hline PBF X CATOL & & & $\begin{array}{l}0.0111^{* * *} \\
(14.85)\end{array}$ & \\
\hline PBF X CATOL (sem Nordeste) & & & & $\begin{array}{l}0.00832^{* * *} \\
(6.91)\end{array}$ \\
\hline Analfabetismo & $\begin{array}{c}0.394^{* * *} \\
(12.92)\end{array}$ & $\begin{array}{c}0.404^{* * *} \\
(13.36)\end{array}$ & $\begin{array}{l}0.182^{* * *} \\
(5.67)\end{array}$ & $\begin{array}{l}0.168^{* * *} \\
(3.63)\end{array}$ \\
\hline Pobreza & $\begin{array}{c}0.373^{* * *} \\
(11.15)\end{array}$ & $\begin{array}{c}0.374^{* * *} \\
(11.36)\end{array}$ & $\begin{array}{l}0.267^{* * *} \\
(8.35)\end{array}$ & $\begin{array}{l}0.243^{* * *} \\
(6.40)\end{array}$ \\
\hline Renda per capita & $\begin{array}{l}-0.00667^{*} \\
(-2.44)\end{array}$ & $\begin{array}{l}-0.00626^{*} \\
(-2.30)\end{array}$ & $\begin{array}{l}-0.00469 \\
(-1.82)\end{array}$ & $\begin{array}{l}-0.00406 \\
(-1.45)\end{array}$ \\
\hline Gini & $\begin{array}{l}-6.355 \\
(-1.84)\end{array}$ & $\begin{array}{c}-6.589 \\
(-1.91)\end{array}$ & $\begin{array}{l}-5.148 \\
(-1.56)\end{array}$ & $\begin{array}{r}-7.760 \\
(-1.80)\end{array}$ \\
\hline Formalização & $\begin{array}{l}-0.0376^{*} \\
(-2.36)\end{array}$ & $\begin{array}{l}-0.0336^{*} \\
(-2.11)\end{array}$ & $\begin{array}{l}-0.00844 \\
(-0.54)\end{array}$ & $\begin{array}{l}0.0477^{\text {** }} \\
(2.89)\end{array}$ \\
\hline Desocupação & $\begin{array}{l}0.286^{* * *} \\
(7.41)\end{array}$ & $\begin{array}{l}0.284^{* * *} \\
(7.59)\end{array}$ & $\begin{array}{l}0.348^{* * *} \\
(9.30)\end{array}$ & $\begin{array}{l}0.457^{* * *} \\
(9.54)\end{array}$ \\
\hline IDHM & $\begin{array}{l}31.19^{* * *} \\
(6.39)\end{array}$ & $\begin{array}{l}31.36^{* * *} \\
(6.43)\end{array}$ & $\begin{array}{l}13.43^{* *} \\
(2.84)\end{array}$ & $\begin{array}{c}-3.119 \\
(-0.58)\end{array}$ \\
\hline Região & $\begin{array}{c}-3.434^{* * *} \\
(-18.53)\end{array}$ & $\begin{array}{c}-3.406^{* * *} \\
(-18.32)\end{array}$ & $\begin{array}{l}-3.160^{* * *} \\
(-17.41)\end{array}$ & $\begin{array}{c}-2.308^{* * *} \\
(-12.58)\end{array}$ \\
\hline Constante & $\begin{array}{l}16.50^{* * *} \\
(4.38)\end{array}$ & $\begin{array}{l}15.60^{* * *} \\
(4.12)\end{array}$ & $\begin{array}{l}25.85^{* * *} \\
(7.17)\end{array}$ & $\begin{array}{l}32.35^{* * *} \\
(8.26)\end{array}$ \\
\hline Observações & 5562 & 5562 & 5562 & 3769 \\
\hline
\end{tabular}

Estatística $t$ entre parênteses

${ }^{\ddagger} p<0.10^{*} p<0.05,{ }^{* *} p<0.01,{ }^{* * *} p<0.001$

Nota: elaborado pelo autor a partir dos dados do Instituto Brasileiro de Geografia e Estatística (IBGE) e do Tribunal Superior Eleitoral (TSE). A variável dependente é a proporção de votos válidos do PT nas eleições presidenciais de 2006. 
Tabela 42 - Efeito do PBF sobre a votação do PT por filiação religiosa - nível municipal (2010)

\begin{tabular}{|c|c|c|c|c|}
\hline & $\begin{array}{c}(1) \\
\text { PT (2010) }\end{array}$ & $\begin{array}{c}(2) \\
\text { PT (2010) }\end{array}$ & $\begin{array}{c}(3) \\
\text { PT (2010) }\end{array}$ & $\begin{array}{c}(4) \\
\text { PT (2010) }\end{array}$ \\
\hline PBF X PENT & $\begin{array}{l}-0.0263^{* * *} \\
(-10.67)\end{array}$ & & & \\
\hline PBF X TRAD & & $\begin{array}{l}-0.0183^{* * *} \\
(-4.75)\end{array}$ & & \\
\hline PBF X CATOL & & & $\begin{array}{l}0.0180^{* * *} \\
(22.93)\end{array}$ & \\
\hline PBF CATOL (sem Nordeste) & & & & $\begin{array}{l}0.0160^{* * *} \\
(14.62)\end{array}$ \\
\hline Analfabetismo & $\begin{array}{l}0.178^{* * *} \\
(6.47)\end{array}$ & $\begin{array}{l}0.218^{* * *} \\
(7.92)\end{array}$ & $\begin{array}{l}-0.0516 \\
(-1.82)\end{array}$ & $\begin{array}{l}-0.113^{* *} \\
(-2.70)\end{array}$ \\
\hline Pobreza & $\begin{array}{l}0.163^{* * *} \\
(5.09)\end{array}$ & $\begin{array}{l}0.126^{* * *} \\
(3.87)\end{array}$ & $\begin{array}{l}-0.0508 \\
(-1.65)\end{array}$ & $\begin{array}{l}0.00996 \\
(0.28)\end{array}$ \\
\hline Renda per capita & $\begin{array}{l}-0.0148^{* * *} \\
(-5.45)\end{array}$ & $\begin{array}{l}-0.0164^{* * *} \\
(-5.81)\end{array}$ & $\begin{array}{l}-0.0168^{* * *} \\
(-6.46)\end{array}$ & $\begin{array}{l}-0.0115^{* * *} \\
(-4.23)\end{array}$ \\
\hline Gini & $\begin{array}{r}5.738 \\
(1.78)\end{array}$ & $\begin{array}{r}5.784 \\
(1.78)\end{array}$ & $\begin{array}{l}8.955^{* *} \\
(2.95)\end{array}$ & $\begin{array}{l}-1.790 \\
(-0.44)\end{array}$ \\
\hline Formalização & $\begin{array}{l}-0.109^{* * *} \\
(-7.26)\end{array}$ & $\begin{array}{l}-0.118^{* * *} \\
(-7.71)\end{array}$ & $\begin{array}{l}-0.0597^{* * *} \\
(-4.01)\end{array}$ & $\begin{array}{l}-0.0110 \\
(-0.68)\end{array}$ \\
\hline Desocupação & $\begin{array}{l}0.0261 \\
(0.81)\end{array}$ & $\begin{array}{l}-0.0422 \\
(-1.33)\end{array}$ & $\begin{array}{l}0.0142 \\
(0.46)\end{array}$ & $\begin{array}{l}0.0161 \\
(0.45)\end{array}$ \\
\hline IDHM & $\begin{array}{l}-24.59^{* * *} \\
(-5.44)\end{array}$ & $\begin{array}{l}-15.84^{* * *} \\
(-3.48)\end{array}$ & $\begin{array}{l}-22.78^{* * *} \\
(-5.40)\end{array}$ & $\begin{array}{l}-31.97^{* * *} \\
(-6.47)\end{array}$ \\
\hline Região & $\begin{array}{l}-0.232 \\
(-1.30)\end{array}$ & $\begin{array}{l}-0.214 \\
(-1.16)\end{array}$ & $\begin{array}{l}0.0858 \\
(0.50)\end{array}$ & $\begin{array}{l}0.576^{* * *} \\
(3.33)\end{array}$ \\
\hline Constante & $\begin{array}{l}62.53^{* * *} \\
(17.47)\end{array}$ & $\begin{array}{l}58.75^{* * *} \\
(16.10)\end{array}$ & $\begin{array}{l}61.12^{* * *} \\
(17.81)\end{array}$ & $\begin{array}{l}64.26^{* * *} \\
(17.16)\end{array}$ \\
\hline Observações & 5562 & 5562 & 5562 & 3769 \\
\hline
\end{tabular}

Estatística $t$ entre parênteses.

${ }^{\ddagger} p<0.10^{*} p<0.05,{ }^{* *} p<0.01,{ }^{* * *} p<0.001$

Nota: elaborado pelo autor a partir dos dados do Instituto Brasileiro de Geografia e Estatística (IBGE) e do Tribunal Superior Eleitoral (TSE). A variável dependente é a proporção de votos válidos do PT nas eleições presidenciais de 2010. 
Tabela 43 - Efeito do PBF sobre a votação do PT por filiação religiosa - nível municipal (2014)

\begin{tabular}{|c|c|c|c|c|}
\hline & $\begin{array}{c}(1) \\
\text { PT (2014) }\end{array}$ & $\begin{array}{c}(2) \\
\text { PT (2014) } \\
\end{array}$ & $\begin{array}{c}\text { (3) } \\
\text { PT (2014) }\end{array}$ & $\begin{array}{c}(4) \\
\text { PT (2014) } \\
\end{array}$ \\
\hline PBF X PENT & $\begin{array}{l}-0.0239^{* * *} \\
(-10.60)\end{array}$ & & & \\
\hline PBF X TRAD & & $\begin{array}{l}-0.00856^{*} \\
(-2.33)\end{array}$ & & \\
\hline PBF X CATOL & & & $\begin{array}{l}0.0188^{* * *} \\
(29.35)\end{array}$ & \\
\hline PBF X CATOL (sem Nordeste) & & & & $\begin{array}{l}0.0171^{* * *} \\
(18.52)\end{array}$ \\
\hline Analfabetismo & $\begin{array}{l}0.0888^{* * *} \\
(3.36)\end{array}$ & $\begin{array}{l}0.148^{* * *} \\
(5.80)\end{array}$ & $\begin{array}{l}-0.185^{* * *} \\
(-7.07)\end{array}$ & $\begin{array}{l}-0.176^{* * *} \\
(-4.53)\end{array}$ \\
\hline Pobreza & $\begin{array}{l}0.371^{* * *} \\
(11.83)\end{array}$ & $\begin{array}{l}0.332^{* * *} \\
(10.50)\end{array}$ & $\begin{array}{l}0.122^{* * *} \\
(4.16)\end{array}$ & $\begin{array}{l}0.146^{* * *} \\
(4.28)\end{array}$ \\
\hline Renda per capita & $\begin{array}{l}-0.00816^{* *} \\
(-3.21)\end{array}$ & $\begin{array}{l}-0.0100^{* * *} \\
(-3.85)\end{array}$ & $\begin{array}{l}-0.0145^{* * *} \\
(-6.10)\end{array}$ & $\begin{array}{l}-0.00979^{* * *} \\
(-3.80)\end{array}$ \\
\hline Gini & $\begin{array}{l}6.625^{*} \\
(2.19)\end{array}$ & $\begin{array}{l}6.537^{*} \\
(2.14)\end{array}$ & $\begin{array}{l}11.65^{* * *} \\
(4.21)\end{array}$ & $\begin{array}{r}3.816 \\
(0.99)\end{array}$ \\
\hline Formalização & $\begin{array}{l}-0.144^{* * *} \\
(-9.18)\end{array}$ & $\begin{array}{l}-0.147^{* * *} \\
(-9.12)\end{array}$ & $\begin{array}{l}-0.0800^{* * *} \\
(-5.41)\end{array}$ & $\begin{array}{l}-0.0260 \\
(-1.59)\end{array}$ \\
\hline Desocupação & $\begin{array}{l}-0.0741^{*} \\
(-2.41)\end{array}$ & $\begin{array}{l}-0.147^{* * *} \\
(-4.72)\end{array}$ & $\begin{array}{l}-0.111^{* * *} \\
(-3.92)\end{array}$ & $\begin{array}{l}-0.0796^{*} \\
(-2.33)\end{array}$ \\
\hline IDHM & $\begin{array}{l}-28.52^{* * *} \\
(-6.43)\end{array}$ & $\begin{array}{l}-16.87^{* * *} \\
(-3.89)\end{array}$ & $\begin{array}{l}-16.06^{* * *} \\
(-4.10)\end{array}$ & $\begin{array}{l}-30.82^{* * *} \\
(-6.50)\end{array}$ \\
\hline Região & $\begin{array}{l}-1.465^{* * *} \\
(-8.62)\end{array}$ & $\begin{array}{l}-1.298^{* * *} \\
(-7.50)\end{array}$ & $\begin{array}{l}-0.547^{* * *} \\
(-3.42)\end{array}$ & $\begin{array}{r}-0.110 \\
(-0.68)\end{array}$ \\
\hline Constante & $\begin{array}{l}53.72^{* * *} \\
(15.01)\end{array}$ & $\begin{array}{l}47.40^{* * *} \\
(13.31)\end{array}$ & $\begin{array}{l}46.76^{* * *} \\
(14.49)\end{array}$ & $\begin{array}{l}52.35^{* * *} \\
(14.70)\end{array}$ \\
\hline Observações & 5562 & 5562 & 5562 & 3769 \\
\hline
\end{tabular}

Estatística $t$ entre parênteses.

${ }^{\ddagger} p<0.10^{*} p<0.05,{ }^{* *} p<0.01,{ }^{* * *} p<0.001$

Nota: elaborado pelo autor a partir dos dados do Instituto Brasileiro de Geografia e Estatística (IBGE) e do Tribunal Superior Eleitoral (TSE). A variável dependente é a proporção de votos válidos do PT nas eleições presidenciais de 2014. 
Tabela 44 - Efeito do PBF sobre a votação do PT por filiação religiosa - nível municipal (2018)

\begin{tabular}{|c|c|c|c|c|}
\hline & $\begin{array}{c}(1) \\
\text { PT (2018) }\end{array}$ & $\begin{array}{c}(2) \\
\text { PT (2018) }\end{array}$ & $\begin{array}{c}\text { (3) } \\
\text { PT (2018) }\end{array}$ & $\begin{array}{c}(4) \\
\text { PT (2018) }\end{array}$ \\
\hline PBF X PENT & $\begin{array}{l}-0.0229^{* * *} \\
(-10.37)\end{array}$ & & & \\
\hline PBF X TRAD & & $\begin{array}{l}-0.000990 \\
(-0.25)\end{array}$ & & \\
\hline PBF X CATOL & & & $\begin{array}{l}0.0176^{* * *} \\
(26.20)\end{array}$ & \\
\hline PBF X CATOL (sem Nordeste) & & & & $\begin{array}{l}0.0195^{* * *} \\
(22.29)\end{array}$ \\
\hline Analfabetismo & $\begin{array}{l}0.179^{* * *} \\
(6.22)\end{array}$ & $\begin{array}{l}0.243^{* * *} \\
(8.59)\end{array}$ & $\begin{array}{l}-0.0756^{* *} \\
(-2.69)\end{array}$ & $\begin{array}{l}0.167^{* * *} \\
(4.09)\end{array}$ \\
\hline Pobreza & $\begin{array}{l}0.546^{* * *} \\
(18.99)\end{array}$ & $\begin{array}{l}0.509^{* * *} \\
(17.77)\end{array}$ & $\begin{array}{l}0.312^{* * *} \\
(11.63)\end{array}$ & $\begin{array}{l}0.310^{* * *} \\
(10.13)\end{array}$ \\
\hline Renda per capita & $\begin{array}{l}0.0103^{* * *} \\
(4.79)\end{array}$ & $\begin{array}{l}0.00865^{* * *} \\
(3.95)\end{array}$ & $\begin{array}{l}0.00431^{*} \\
(2.14)\end{array}$ & $\begin{array}{l}0.00137 \\
(0.62)\end{array}$ \\
\hline Gini & $\begin{array}{l}-8.782^{* *} \\
(-2.84)\end{array}$ & $\begin{array}{l}-9.045^{* *} \\
(-2.90)\end{array}$ & $\begin{array}{l}-4.079 \\
(-1.41)\end{array}$ & $\begin{array}{l}-3.074 \\
(-0.83)\end{array}$ \\
\hline Formalização & $\begin{array}{l}-0.0646^{* * *} \\
(-4.46)\end{array}$ & $\begin{array}{l}-0.0647^{* * *} \\
(-4.39)\end{array}$ & $\begin{array}{l}-0.00485 \\
(-0.36)\end{array}$ & $\begin{array}{l}0.0399^{* *} \\
(2.75)\end{array}$ \\
\hline Desocupação & $\begin{array}{l}0.162^{* * *} \\
(4.80)\end{array}$ & $\begin{array}{l}0.0877^{* *} \\
(2.69)\end{array}$ & $\begin{array}{l}0.125^{* * *} \\
(4.20)\end{array}$ & $\begin{array}{l}-0.0625^{*} \\
(-1.97)\end{array}$ \\
\hline IDHM & $\begin{array}{l}-66.28^{* * *} \\
(-14.97)\end{array}$ & $\begin{array}{l}-54.37^{* * *} \\
(-12.34)\end{array}$ & $\begin{array}{l}-54.33^{* * *} \\
(-13.33)\end{array}$ & $\begin{array}{l}-20.18^{* * *} \\
(-4.75)\end{array}$ \\
\hline Região & $\begin{array}{l}-0.852^{* * *} \\
(-5.02)\end{array}$ & $\begin{array}{l}-0.665^{* * *} \\
(-3.84)\end{array}$ & $\begin{array}{l}0.0117 \\
(0.07)\end{array}$ & $\begin{array}{c}0.184 \\
(1.20)\end{array}$ \\
\hline Constante & $\begin{array}{l}43.74^{* * *} \\
(12.83)\end{array}$ & $\begin{array}{l}36.82^{* * *} \\
(10.73)\end{array}$ & $\begin{array}{l}37.06^{* * *} \\
(11.99)\end{array}$ & $\begin{array}{l}12.21^{* * *} \\
(3.86)\end{array}$ \\
\hline Observações & 5562 & 5562 & 5562 & 3769 \\
\hline
\end{tabular}

Estatística $t$ entre parênteses

${ }^{\ddagger} p<0.10^{*} p<0.05,{ }^{* *} p<0.01,{ }^{* * *} p<0.001$

Nota: elaborado pelo autor a partir dos dados do Instituto Brasileiro de Geografia e Estatística (IBGE) e do Tribunal Superior Eleitoral (TSE). A variável dependente é a proporção de votos válidos do PT nas eleições presidenciais de 2018. 
Tabela 45 - Efeito do PBF sobre a votação do PT por filiação religiosa - nível individual (2010)

\begin{tabular}{|c|c|c|c|c|}
\hline & $\begin{array}{c}(1) \\
\text { PT }(2010)\end{array}$ & $\begin{array}{c}(2) \\
\text { PT }(2010)\end{array}$ & $\begin{array}{c}\text { (3) } \\
\text { PT (2010) }\end{array}$ & $\begin{array}{c}(4) \\
\text { PT (2010) }\end{array}$ \\
\hline PBF X PENT & $\begin{array}{l}0.0622 \\
(0.38)\end{array}$ & & & \\
\hline PBF X TRAD & & $\begin{array}{c}0.582 \\
(1.54)\end{array}$ & & \\
\hline PBF X CATOL & & & $\begin{array}{l}0.494^{* * *} \\
(4.64)\end{array}$ & \\
\hline PBF X CATOL (sem Nordeste) & & & & $\begin{array}{l}0.372^{* *} \\
(2.78)\end{array}$ \\
\hline Idade & $\begin{array}{l}0.0170^{* * *} \\
(6.16)\end{array}$ & $\begin{array}{l}0.0170^{* * *} \\
(6.19)\end{array}$ & $\begin{array}{l}0.0174^{* * *} \\
(6.30)\end{array}$ & $\begin{array}{l}0.0149^{* * *} \\
(4.91)\end{array}$ \\
\hline Gênero & $\begin{array}{l}-0.0688 \\
(-0.91)\end{array}$ & $\begin{array}{l}-0.0666 \\
(-0.88)\end{array}$ & $\begin{array}{l}-0.0684 \\
(-0.90)\end{array}$ & $\begin{array}{l}-0.0520 \\
(-0.62)\end{array}$ \\
\hline Escolaridade & $\begin{array}{l}-0.00426 \\
(-0.23)\end{array}$ & $\begin{array}{l}-0.00461 \\
(-0.25)\end{array}$ & $\begin{array}{l}0.00635 \\
(0.34)\end{array}$ & $\begin{array}{l}0.0166 \\
(0.78)\end{array}$ \\
\hline Renda & $\begin{array}{l}0.0918^{* *} \\
(3.22)\end{array}$ & $\begin{array}{l}0.0914^{* *} \\
(3.20)\end{array}$ & $\begin{array}{l}0.0789^{* *} \\
(2.74)\end{array}$ & $\begin{array}{l}0.0979^{* *} \\
(3.04)\end{array}$ \\
\hline Raça & $\begin{array}{l}-0.163^{* *} \\
(-3.12)\end{array}$ & $\begin{array}{l}-0.164^{* *} \\
(-3.15)\end{array}$ & $\begin{array}{l}-0.160^{* *} \\
(-3.03)\end{array}$ & $\begin{array}{l}-0.150^{*} \\
(-2.56)\end{array}$ \\
\hline Ocupação & $\begin{array}{l}-0.243 \\
(-1.09)\end{array}$ & $\begin{array}{c}-0.249 \\
(-1.12)\end{array}$ & $\begin{array}{l}-0.248 \\
(-1.12)\end{array}$ & $\begin{array}{l}-0.0552 \\
(-0.22)\end{array}$ \\
\hline Percep. economia & $\begin{array}{l}0.371^{* * *} \\
(4.51)\end{array}$ & $\begin{array}{l}0.372^{* * *} \\
(4.52)\end{array}$ & $\begin{array}{l}0.351^{* * *} \\
(4.27)\end{array}$ & $\begin{array}{l}0.358^{* * *} \\
(3.91)\end{array}$ \\
\hline Pref. Partido & $\begin{array}{l}0.659^{* *} \\
(2.70)\end{array}$ & $\begin{array}{l}0.649^{* *} \\
(2.66)\end{array}$ & $\begin{array}{l}0.672^{* *} \\
(2.77)\end{array}$ & $\begin{array}{l}0.826^{* *} \\
(3.08)\end{array}$ \\
\hline Região & $\begin{array}{l}-0.185^{* * *} \\
(-4.23)\end{array}$ & $\begin{array}{l}-0.185^{* * *} \\
(-4.22)\end{array}$ & $\begin{array}{l}-0.156^{* * *} \\
(-3.55)\end{array}$ & $\begin{array}{l}-0.00634 \\
(-0.13)\end{array}$ \\
\hline Freq. Igreja & $\begin{array}{l}-0.0190 \\
(-0.24)\end{array}$ & $\begin{array}{l}-0.0228 \\
(-0.29)\end{array}$ & $\begin{array}{l}0.0130 \\
(0.17)\end{array}$ & $\begin{array}{l}0.0452 \\
(0.52)\end{array}$ \\
\hline Constante & $\begin{array}{c}-0.271 \\
(-0.96)\end{array}$ & $\begin{array}{c}-0.269 \\
(-0.95)\end{array}$ & $\begin{array}{l}-0.457 \\
(-1.59)\end{array}$ & $\begin{array}{l}-1.090^{* *} \\
(-3.28)\end{array}$ \\
\hline Observações & 3049 & 3049 & 3049 & 2426 \\
\hline
\end{tabular}

Estatística $t$ em parênteses

${ }^{\ddagger} p<0.10^{*} p<0.05,{ }^{* *} p<0.01,{ }^{* * *} p<0.001$

Nota: elaborado pelo autor a partir dos dados do Estudo Eleitoral Brasileiro (ESEB, 2014). A variável dependente assume valor 1 se o indivíduo votou no PT em 2010 e 0, caso contrário. 
Tabela 46 - Efeito do PBF sobre a votação do PT por filiação religiosa - nível individual (2014)

\begin{tabular}{|c|c|c|c|c|}
\hline & $\begin{array}{c}(1) \\
\text { PT (2014) }\end{array}$ & $\begin{array}{c}(2) \\
\text { Voto }(2014)\end{array}$ & $\begin{array}{c}(3) \\
\text { PT (2014) }\end{array}$ & $\begin{array}{c}(4) \\
\text { PT (2014) }\end{array}$ \\
\hline PBF X PENT & $\begin{array}{l}0.0821 \\
(0.49)\end{array}$ & & & \\
\hline PBF X TRAD & & $\begin{array}{r}0.651 \\
(1.56)\end{array}$ & & \\
\hline PBF X CATOL & & & $\begin{array}{l}0.573^{* * *} \\
(5.20)\end{array}$ & \\
\hline PBF CATOL (sem Nordeste) & & & & $\begin{array}{l}0.463^{* * *} \\
(3.34)\end{array}$ \\
\hline Idade & $\begin{array}{l}-0.00361 \\
(-1.28)\end{array}$ & $\begin{array}{l}-0.00362 \\
(-1.29)\end{array}$ & $\begin{array}{l}-0.00332 \\
(-1.18)\end{array}$ & $\begin{array}{l}-0.00325 \\
(-1.03)\end{array}$ \\
\hline Gênero & $\begin{array}{l}0.0579 \\
(0.74)\end{array}$ & $\begin{array}{l}0.0605 \\
(0.78)\end{array}$ & $\begin{array}{l}0.0606 \\
(0.78)\end{array}$ & $\begin{array}{l}0.0306 \\
(0.35)\end{array}$ \\
\hline Escolaridade & $\begin{array}{l}-0.107^{\text {*** }} \\
(-5.52)\end{array}$ & $\begin{array}{l}-0.107^{* * *} \\
(-5.57)\end{array}$ & $\begin{array}{l}-0.0953^{* * *} \\
(-4.91)\end{array}$ & $\begin{array}{l}-0.0887^{* * *} \\
(-4.04)\end{array}$ \\
\hline Renda & $\begin{array}{l}0.0918^{* *} \\
(3.12)\end{array}$ & $\begin{array}{l}0.0914^{* *} \\
(3.11)\end{array}$ & $\begin{array}{l}0.0765^{*} \\
(2.57)\end{array}$ & $\begin{array}{l}0.0906^{* *} \\
(2.73)\end{array}$ \\
\hline Raça & $\begin{array}{l}-0.194^{* * *} \\
(-3.56)\end{array}$ & $\begin{array}{l}-0.196^{* * *} \\
(-3.58)\end{array}$ & $\begin{array}{l}-0.190^{* * *} \\
(-3.46)\end{array}$ & $\begin{array}{l}-0.191^{* *} \\
(-3.10)\end{array}$ \\
\hline Ocupação & $\begin{array}{l}-0.0249 \\
(-0.11)\end{array}$ & $\begin{array}{l}-0.0330 \\
(-0.15)\end{array}$ & $\begin{array}{l}-0.0306 \\
(-0.14)\end{array}$ & $\begin{array}{l}0.0219 \\
(0.09)\end{array}$ \\
\hline Percep. economia & $\begin{array}{c}0.904^{* * *} \\
(10.49)\end{array}$ & $\begin{array}{c}0.906^{* * *} \\
(10.50)\end{array}$ & $\begin{array}{c}0.885^{\text {*** }} \\
(10.24)\end{array}$ & $\begin{array}{l}0.829^{* * *} \\
(8.60)\end{array}$ \\
\hline Pref. Partido & $\begin{array}{c}0.199 \\
(0.84)\end{array}$ & $\begin{array}{c}0.183 \\
(0.77)\end{array}$ & $\begin{array}{c}0.213 \\
(0.91)\end{array}$ & $\begin{array}{c}0.277 \\
(1.05)\end{array}$ \\
\hline Região & $\begin{array}{l}-0.330^{* * *} \\
(-7.17)\end{array}$ & $\begin{array}{l}-0.330^{* * *} \\
(-7.15)\end{array}$ & $\begin{array}{l}-0.297^{* * *} \\
(-6.42)\end{array}$ & $\begin{array}{l}-0.152^{* *} \\
(-2.97)\end{array}$ \\
\hline Freq. Igreja & $\begin{array}{l}-0.0333 \\
(-0.41)\end{array}$ & $\begin{array}{l}-0.0362 \\
(-0.45)\end{array}$ & $\begin{array}{l}0.00414 \\
(0.05)\end{array}$ & $\begin{array}{l}0.0830 \\
(0.93)\end{array}$ \\
\hline Constante & $\begin{array}{l}0.885^{* *} \\
(2.98) \\
\end{array}$ & $\begin{array}{l}0.889^{* *} \\
(3.00)\end{array}$ & $\begin{array}{l}0.680^{*} \\
(2.27) \\
\end{array}$ & $\begin{array}{c}0.122 \\
(0.35) \\
\end{array}$ \\
\hline Observações & 3049 & 3049 & 3049 & 2426 \\
\hline
\end{tabular}

Estatística $t$ em parênteses.

${ }^{\ddagger} p<0.10^{*} p<0.05,{ }^{* *} p<0.01,{ }^{* * *} p<0.001$

Nota: elaborado pelo autor a partir dos dados do Estudo Eleitoral Brasileiro (ESEB, 2014). A variável dependente assume valor 1 se o indivíduo votou no PT em 2014 e 0, caso contrário. 
Tabela 47 - Acesso aos programas sociais por filiação religiosa - Bolsa Família (2010)

\begin{tabular}{|c|c|c|c|}
\hline & $\begin{array}{c}(1) \\
\text { PBF }\end{array}$ & $\begin{array}{c}(2) \\
\text { PBF }\end{array}$ & $\begin{array}{c}(3) \\
\text { PBF }\end{array}$ \\
\hline Pentecostais & $\begin{array}{l}0.0807 \\
(0.42)\end{array}$ & & \\
\hline Tradicionais & & $\begin{array}{l}-0.0593 \\
(-0.23)\end{array}$ & \\
\hline Católicos & & & $\begin{array}{l}0.0564 \\
(0.41)\end{array}$ \\
\hline Idade & $\begin{array}{l}-0.0491^{\text {*** }} \\
(-10.11)\end{array}$ & $\begin{array}{l}-0.0490^{* * *} \\
(-10.08)\end{array}$ & $\begin{array}{l}-0.0491^{* * *} \\
(-10.10)\end{array}$ \\
\hline Escolaridade & $\begin{array}{c}-0.418^{* * *} \\
(-11.40)\end{array}$ & $\begin{array}{l}-0.417^{* * *} \\
(-11.37)\end{array}$ & $\begin{array}{c}-0.416^{* * *} \\
(-11.37)\end{array}$ \\
\hline Renda & $\begin{array}{l}-0.0908^{* *} \\
(-3.00)\end{array}$ & $\begin{array}{l}-0.0909^{* *} \\
(-3.01)\end{array}$ & $\begin{array}{l}-0.0908^{* *} \\
(-3.01)\end{array}$ \\
\hline Raça & $\begin{array}{c}0.179^{*} \\
(2.54)\end{array}$ & $\begin{array}{c}0.179^{*} \\
(2.54)\end{array}$ & $\begin{array}{l}0.179^{*} \\
(2.55)\end{array}$ \\
\hline Gênero & $\begin{array}{l}0.922^{* * *} \\
(6.44)\end{array}$ & $\begin{array}{l}0.927^{* * *} \\
(6.46)\end{array}$ & $\begin{array}{l}0.928^{* * *} \\
(6.46)\end{array}$ \\
\hline Região & $\begin{array}{l}-0.317^{* * *} \\
(-5.68)\end{array}$ & $\begin{array}{l}-0.317^{* * *} \\
(-5.67)\end{array}$ & $\begin{array}{l}-0.316^{* * *} \\
(-5.66)\end{array}$ \\
\hline Constante & $\begin{array}{l}1.585^{* * *} \\
(3.52)\end{array}$ & $\begin{array}{l}1.583^{* * *} \\
(3.52)\end{array}$ & $\begin{array}{l}1.539^{* * *} \\
(3.30)\end{array}$ \\
\hline Observações & 1961 & 1961 & 1961 \\
\hline
\end{tabular}

Estatística $t$ entre parênteses.

${ }^{\ddagger} p<0.10^{*} p<0.05,{ }^{* *} p<0.01,{ }^{* * *} p<0.001$

Nota: elaborado pelo autor a partir dos dados do Estudo Eleitoral Brasileiro (ESEB, 2010). PBF = Programa Bolsa Família. A variável dependente assume valor 1 se o indivíduo era um beneficiário do PBF em 2010 e 0 , caso contrário. 
Tabela 48 - Acesso aos programas sociais por filiação religiosa - Luz para Todos (2010)

\begin{tabular}{|c|c|c|c|}
\hline & $\begin{array}{c}(1) \\
\mathrm{LPT}\end{array}$ & $\begin{array}{c}(2) \\
\mathrm{LPT}\end{array}$ & $\begin{array}{c}(3) \\
\mathrm{LPT}\end{array}$ \\
\hline Pentecostais & $\begin{array}{c}0.211 \\
(0.60)\end{array}$ & & \\
\hline Tradicionais & & $\begin{array}{c}-0.738 \\
(-1.02)\end{array}$ & \\
\hline Católicos & & & $\begin{array}{c}0.183 \\
(0.64)\end{array}$ \\
\hline Idade & $\begin{array}{l}-0.00817 \\
(-0.86)\end{array}$ & $\begin{array}{l}-0.00791 \\
(-0.83)\end{array}$ & $\begin{array}{l}-0.00833 \\
(-0.87)\end{array}$ \\
\hline Escolaridade & $\begin{array}{c}-0.186^{*} \\
(-2.35)\end{array}$ & $\begin{array}{l}-0.181^{*} \\
(-2.31)\end{array}$ & $\begin{array}{c}-0.181^{*} \\
(-2.28)\end{array}$ \\
\hline Renda & $\begin{array}{l}-0.0676 \\
(-0.99)\end{array}$ & $\begin{array}{l}-0.0701 \\
(-1.03)\end{array}$ & $\begin{array}{l}-0.0670 \\
(-0.99)\end{array}$ \\
\hline Raça & $\begin{array}{r}0.207 \\
(1.44)\end{array}$ & $\begin{array}{c}0.213 \\
(1.49)\end{array}$ & $\begin{array}{c}0.209 \\
(1.46)\end{array}$ \\
\hline Gênero & $\begin{array}{c}-0.298 \\
(-1.16)\end{array}$ & $\begin{array}{r}-0.267 \\
(-1.02)\end{array}$ & $\begin{array}{r}-0.281 \\
(-1.08)\end{array}$ \\
\hline Região & $\begin{array}{c}-0.150 \\
(-1.06)\end{array}$ & $\begin{array}{c}-0.149 \\
(-1.04)\end{array}$ & $\begin{array}{c}-0.146 \\
(-1.03)\end{array}$ \\
\hline Constante & $\begin{array}{c}-1.658 \\
(-1.80)\end{array}$ & $\begin{array}{l}-1.682 \\
(-1.83)\end{array}$ & $\begin{array}{l}-1.805 \\
(-1.90)\end{array}$ \\
\hline Observações & 1961 & 1961 & 1961 \\
\hline
\end{tabular}

Estatística $t$ entre parênteses

${ }^{\ddagger} p<0.10 * p<0.05,{ }^{* *} p<0.01,{ }^{* * *} p<0.001$

Nota: elaborado pelo autor a partir dos dados do Estudo Eleitoral Brasileiro (ESEB, 2010). LPT = Programa Luz para Todos. A variável dependente assume valor 1 se o indivíduo era um beneficiário do LPT em 2010 e 0 , caso contrário. 
Tabela 49 - Acesso aos programas sociais por filiação religiosa - Minha Casa, Minha Vida (2010)

\begin{tabular}{|c|c|c|c|}
\hline & $\begin{array}{c}(1) \\
\text { MCMV }\end{array}$ & $\begin{array}{c}(2) \\
\mathrm{MCMV}\end{array}$ & $\begin{array}{c}(3) \\
\text { MCMV }\end{array}$ \\
\hline Pentecostais & $\begin{array}{l}-0.0407 \\
(-0.10)\end{array}$ & & \\
\hline Tradicionais & & $\begin{array}{c}0.164 \\
(0.34)\end{array}$ & \\
\hline Católicos & & & $\begin{array}{l}-0.0407 \\
(-0.14)\end{array}$ \\
\hline Idade & $\begin{array}{l}-0.0235^{*} \\
(-2.24)\end{array}$ & $\begin{array}{l}-0.0237^{*} \\
(-2.24)\end{array}$ & $\begin{array}{l}-0.0235^{*} \\
(-2.25)\end{array}$ \\
\hline Escolaridade & $\begin{array}{l}-0.0419 \\
(-0.64)\end{array}$ & $\begin{array}{l}-0.0432 \\
(-0.66)\end{array}$ & $\begin{array}{l}-0.0429 \\
(-0.65)\end{array}$ \\
\hline Renda & $\begin{array}{l}-0.179^{* *} \\
(-2.76)\end{array}$ & $\begin{array}{l}-0.179^{* *} \\
(-2.73)\end{array}$ & $\begin{array}{l}-0.179^{* *} \\
(-2.77)\end{array}$ \\
\hline Raça & $\begin{array}{l}0.279^{*} \\
(2.02)\end{array}$ & $\begin{array}{l}0.276^{*} \\
(2.00)\end{array}$ & $\begin{array}{l}0.279^{*} \\
(2.00)\end{array}$ \\
\hline Gênero & $\begin{array}{l}0.595^{*} \\
(2.09)\end{array}$ & $\begin{array}{l}0.588^{*} \\
(2.08)\end{array}$ & $\begin{array}{c}0.592^{*} \\
(2.08)\end{array}$ \\
\hline Região & $\begin{array}{l}-0.0742 \\
(-0.60)\end{array}$ & $\begin{array}{l}-0.0749 \\
(-0.61)\end{array}$ & $\begin{array}{l}-0.0754 \\
(-0.61)\end{array}$ \\
\hline Constante & $\begin{array}{l}-3.283^{* * *} \\
(-3.95)\end{array}$ & $\begin{array}{l}-3.273^{* * *} \\
(-3.91)\end{array}$ & $\begin{array}{l}-3.250^{* * *} \\
(-3.48)\end{array}$ \\
\hline Observações & 1961 & 1961 & 1961 \\
\hline
\end{tabular}

Estatística $t$ entre parênteses.

${ }^{\ddagger} p<0.10^{*} p<0.05,{ }^{* *} p<0.01,{ }^{* * *} p<0.001$

Nota: elaborado pelo autor a partir dos dados do Estudo Eleitoral Brasileiro (ESEB, 2010). MCMV = Programa Minha Casa, Minha Vida. A variável dependente assume valor 1 se o indivíduo era um beneficiário do MCMV em 2010 e 0, caso contrário. 
Tabela 50 - Avaliação da situação econômica por filiação religiosa - nível individual (2010)

\begin{tabular}{|c|c|c|c|}
\hline & $\begin{array}{c}(1) \\
\text { Bem-estar }\end{array}$ & $\begin{array}{c}(2) \\
\text { Bem-estar }\end{array}$ & $\begin{array}{c}(3) \\
\text { Bem-estar }\end{array}$ \\
\hline PBF X PENT & $\begin{array}{c}0.571^{\ddagger} \\
(1.79)\end{array}$ & & \\
\hline PBF X TRAD & & $\begin{array}{l}-0.535 \\
(-1.20)\end{array}$ & \\
\hline PBF X CATOL & & & $\begin{array}{l}-0.0181 \\
(-0.12)\end{array}$ \\
\hline Idade & $\begin{array}{l}-0.00891^{* *} \\
(-2.72)\end{array}$ & $\begin{array}{l}0.00392 \\
(1.18)\end{array}$ & $\begin{array}{l}0.00405 \\
(1.21)\end{array}$ \\
\hline Gênero & $\begin{array}{l}-0.0809 \\
(-0.87)\end{array}$ & $\begin{array}{l}-0.313^{* * *} \\
(-3.34)\end{array}$ & $\begin{array}{l}-0.319^{* * *} \\
(-3.41)\end{array}$ \\
\hline Raça & $\begin{array}{l}0.0594 \\
(1.20)\end{array}$ & $\begin{array}{l}-0.0488 \\
(-0.98)\end{array}$ & $\begin{array}{l}-0.0509 \\
(-1.02)\end{array}$ \\
\hline Escolaridade & $\begin{array}{l}-0.0297 \\
(-1.31)\end{array}$ & $\begin{array}{l}0.0731^{* *} \\
(3.19)\end{array}$ & $\begin{array}{l}0.0732^{* *} \\
(3.12)\end{array}$ \\
\hline Renda & $\begin{array}{l}-0.0144 \\
(-0.72)\end{array}$ & $\begin{array}{l}0.0269 \\
(1.36)\end{array}$ & $\begin{array}{l}0.0276 \\
(1.40)\end{array}$ \\
\hline Percep. economia & $\begin{array}{l}0.420^{*} \\
(2.27)\end{array}$ & $\begin{array}{l}0.957^{* * *} \\
(4.69)\end{array}$ & $\begin{array}{l}0.954^{* * *} \\
(4.68)\end{array}$ \\
\hline Região & $\begin{array}{l}-0.193^{* * *} \\
(-4.83)\end{array}$ & $\begin{array}{l}0.0272 \\
(0.69)\end{array}$ & $\begin{array}{l}0.0283 \\
(0.71)\end{array}$ \\
\hline Constante & $\begin{array}{l}1.149^{* * *} \\
(3.54)\end{array}$ & $\begin{array}{l}-0.0406 \\
(-0.13)\end{array}$ & $\begin{array}{l}-0.0416 \\
(-0.13)\end{array}$ \\
\hline Observações & 1961 & 1961 & 1961 \\
\hline
\end{tabular}

Estatística $t$ entre parênteses.

${ }^{\ddagger} p<0.10^{*} p<0.05,{ }^{* *} p<0.01,{ }^{* * *} p<0.001$

Nota: elaborado pelo autor a partir dos dados do Estudo Eleitoral Brasileiro (ESEB, 2010). A variável dependente assume o valor 1 se o indivíduo avalia que sua situação econômica está melhor do que há doze meses e 0 , caso contrário. 
Tabela 51 - Efeito do CS sobre a votação do PS por filiação religiosa (2014)

\begin{tabular}{|c|c|c|c|}
\hline & $\begin{array}{c}(1) \\
\text { PS (2013) }\end{array}$ & $\begin{array}{c}(2) \\
\text { PS (2013) }\end{array}$ & $\begin{array}{c}(3) \\
\text { PS (2013) }\end{array}$ \\
\hline CS X PENT & $\begin{array}{c}-0.794^{* * *} \\
(-14.94)\end{array}$ & & \\
\hline CS X TRAD & & $\begin{array}{l}0.311^{* * *} \\
(6.61)\end{array}$ & \\
\hline CS X CATOL & & & $\begin{array}{l}0.0793 \\
(0.83)\end{array}$ \\
\hline Idade & $\begin{array}{l}0.000298 \\
(0.22)\end{array}$ & $\begin{array}{l}0.000414 \\
(0.31)\end{array}$ & $\begin{array}{l}0.000415 \\
(0.31)\end{array}$ \\
\hline Gênero & $\begin{array}{l}0.0480 \\
(1.13)\end{array}$ & $\begin{array}{l}0.0480 \\
(1.13)\end{array}$ & $\begin{array}{l}0.0522 \\
(1.22)\end{array}$ \\
\hline Raça & $\begin{array}{l}-0.0386 \\
(-1.65)\end{array}$ & $\begin{array}{l}-0.0376 \\
(-1.61)\end{array}$ & $\begin{array}{l}-0.0377 \\
(-1.62)\end{array}$ \\
\hline Escolaridade & $\begin{array}{l}-0.101^{* *} \\
(-2.98)\end{array}$ & $\begin{array}{l}-0.0998^{* *} \\
(-2.93)\end{array}$ & $\begin{array}{l}-0.0987^{* *} \\
(-2.90)\end{array}$ \\
\hline Renda & $\begin{array}{l}-0.00833 \\
(-1.65)\end{array}$ & $\begin{array}{l}-0.00786 \\
(-1.55)\end{array}$ & $\begin{array}{l}-0.00781 \\
(-1.55)\end{array}$ \\
\hline Ocupação & $\begin{array}{l}-0.244^{*} \\
(-2.13)\end{array}$ & $\begin{array}{l}-0.242^{*} \\
(-2.12)\end{array}$ & $\begin{array}{l}-0.246^{*} \\
(-2.18)\end{array}$ \\
\hline Percep. economia & $\begin{array}{l}0.163^{* * *} \\
(3.59)\end{array}$ & $\begin{array}{l}0.167^{* * *} \\
(3.68)\end{array}$ & $\begin{array}{l}0.166^{* * *} \\
(3.67)\end{array}$ \\
\hline Pref. partido & $\begin{array}{l}-0.0000751 \\
(-1.89)\end{array}$ & $\begin{array}{l}-0.0000731 \\
(-1.84)\end{array}$ & $\begin{array}{l}-0.0000716 \\
(-1.79)\end{array}$ \\
\hline Urbano & $\begin{array}{l}-0.0184 \\
(-0.36)\end{array}$ & $\begin{array}{l}-0.0152 \\
(-0.29)\end{array}$ & $\begin{array}{l}-0.0151 \\
(-0.29)\end{array}$ \\
\hline Religiosidade & $\begin{array}{l}0.0821^{*} \\
(2.07)\end{array}$ & $\begin{array}{l}0.0755 \\
(1.90)\end{array}$ & $\begin{array}{l}0.0757 \\
(1.91)\end{array}$ \\
\hline Pref. taxação & $\begin{array}{l}0.0399 \\
(0.87)\end{array}$ & $\begin{array}{l}0.0448 \\
(0.98)\end{array}$ & $\begin{array}{l}0.0419 \\
(0.92)\end{array}$ \\
\hline Percep. Desigualdade & $\begin{array}{l}0.0495 \\
(0.96)\end{array}$ & $\begin{array}{l}0.0444 \\
(0.86)\end{array}$ & $\begin{array}{l}0.0451 \\
(0.88)\end{array}$ \\
\hline Constante & $\begin{array}{l}0.899^{* * *} \\
(7.03)\end{array}$ & $\begin{array}{l}0.883^{* * *} \\
(6.88)\end{array}$ & $\begin{array}{l}0.876^{* * *} \\
(6.78)\end{array}$ \\
\hline Observações & 573 & 573 & 573 \\
\hline
\end{tabular}

Nota: elaborado pelo autor a partir dos dados do LAPOP (2014). A variável dependente assume valor 1 se o indivíduo votou no PS nas eleições presidenciais de 2013 e 0, caso contrário. 
Tabela 52 - Opinião sobre o aborto em situações extremas por filiação religiosa (2014)

\begin{tabular}{|c|c|c|c|}
\hline & $\begin{array}{c}(1) \\
\text { Aborto }\end{array}$ & $\begin{array}{c}(2) \\
\text { Aborto }\end{array}$ & $\begin{array}{c}(3) \\
\text { Aborto }\end{array}$ \\
\hline Pentecostais & $\begin{array}{l}-0.588^{* *} \\
(-2.84)\end{array}$ & & \\
\hline Tradicionais & & $\begin{array}{c}0.264 \\
(1.10)\end{array}$ & \\
\hline Católicos & & & $\begin{array}{r}0.235 \\
(1.55)\end{array}$ \\
\hline Idade & $\begin{array}{l}-0.00118 \\
(-0.26)\end{array}$ & $\begin{array}{l}0.000443 \\
(0.10)\end{array}$ & $\begin{array}{l}-0.000522 \\
(-0.12)\end{array}$ \\
\hline Gênero & $\begin{array}{l}-0.336^{*} \\
(-2.21)\end{array}$ & $\begin{array}{l}-0.352^{*} \\
(-2.31)\end{array}$ & $\begin{array}{l}-0.313^{*} \\
(-2.05)\end{array}$ \\
\hline Raça & $\begin{array}{l}-0.0531 \\
(-0.66)\end{array}$ & $\begin{array}{l}-0.0613 \\
(-0.77)\end{array}$ & $\begin{array}{l}-0.0632 \\
(-0.79)\end{array}$ \\
\hline Escolaridade & $\begin{array}{r}0.226 \\
(1.78)\end{array}$ & $\begin{array}{r}0.237 \\
(1.87)\end{array}$ & $\begin{array}{r}0.247 \\
(1.95)\end{array}$ \\
\hline Renda & $\begin{array}{l}0.0392^{*} \\
(2.20)\end{array}$ & $\begin{array}{l}0.0430^{*} \\
(2.43)\end{array}$ & $\begin{array}{l}0.0416^{*} \\
(2.35)\end{array}$ \\
\hline Urbano & $\begin{array}{c}0.275 \\
(1.49)\end{array}$ & $\begin{array}{r}0.310 \\
(1.70)\end{array}$ & $\begin{array}{c}0.302 \\
(1.65)\end{array}$ \\
\hline Religiosidade & $\begin{array}{l}-0.509^{* * *} \\
(-3.36)\end{array}$ & $\begin{array}{l}-0.610^{* * *} \\
(-4.18)\end{array}$ & $\begin{array}{l}-0.604^{* * *} \\
(-4.14)\end{array}$ \\
\hline Constante & $\begin{array}{l}0.0595 \\
(0.14)\end{array}$ & $\begin{array}{r}-0.157 \\
(-0.38)\end{array}$ & $\begin{array}{c}-0.262 \\
(-0.61)\end{array}$ \\
\hline Observações & 950 & 950 & 950 \\
\hline
\end{tabular}

Nota: elaborado pelo autor a partir dos dados do LAPOP (2014). A variável dependente assume valor 1 se o indivíduo concorda com um aborto em circunstâncias extremas, como o risco de morte da gestante, e 0 , caso contrário. 
Tabela 53 - Preferência por redistribuição dos beneficiários do CS por filiação religiosa (2014)

\begin{tabular}{|c|c|c|c|}
\hline & $\begin{array}{c}(1) \\
\text { Redistribuição }\end{array}$ & $\begin{array}{c}(2) \\
\text { Redistribuição }\end{array}$ & $\begin{array}{c}(3) \\
\text { Redistribuição }\end{array}$ \\
\hline CS X PENT & $\begin{array}{l}0.0548 \\
(0.32)\end{array}$ & & \\
\hline CS X TRAD & & $\begin{array}{l}0.427^{* * *} \\
(10.14)\end{array}$ & \\
\hline CS X CATOL & & & $\begin{array}{l}0.0982 \\
(1.32)\end{array}$ \\
\hline Idade & $\begin{array}{l}0.00107 \\
(1.06)\end{array}$ & $\begin{array}{l}0.00112 \\
(1.11)\end{array}$ & $\begin{array}{l}0.00111 \\
(1.10)\end{array}$ \\
\hline Gênero & $\begin{array}{l}0.0910^{* *} \\
(2.75)\end{array}$ & $\begin{array}{l}0.0907^{* *} \\
(2.74)\end{array}$ & $\begin{array}{l}0.0911^{\text {** }} \\
(2.75)\end{array}$ \\
\hline Raça & $\begin{array}{l}0.00383 \\
(0.22)\end{array}$ & $\begin{array}{l}0.00403 \\
(0.23)\end{array}$ & $\begin{array}{l}0.00464 \\
(0.26)\end{array}$ \\
\hline Escolaridade & $\begin{array}{l}0.0302 \\
(1.01)\end{array}$ & $\begin{array}{l}0.0301 \\
(1.01)\end{array}$ & $\begin{array}{l}0.0306 \\
(1.03)\end{array}$ \\
\hline Renda & $\begin{array}{l}-0.00422 \\
(-1.06)\end{array}$ & $\begin{array}{l}-0.00383 \\
(-0.96)\end{array}$ & $\begin{array}{l}-0.00391 \\
(-0.98)\end{array}$ \\
\hline Urbano & $\begin{array}{l}0.181^{\text {*** }} \\
(4.38)\end{array}$ & $\begin{array}{l}0.179^{* * *} \\
(4.31)\end{array}$ & $\begin{array}{l}0.180^{* * *} \\
(4.34)\end{array}$ \\
\hline Religiosidade & $\begin{array}{l}-0.00265 \\
(-0.08)\end{array}$ & $\begin{array}{l}0.000419 \\
(0.01)\end{array}$ & $\begin{array}{l}-0.00291 \\
(-0.09)\end{array}$ \\
\hline Constante & $\begin{array}{l}0.279^{* *} \\
(2.91)\end{array}$ & $\begin{array}{l}0.273^{* *} \\
(2.85)\end{array}$ & $\begin{array}{l}0.270^{* *} \\
(2.81)\end{array}$ \\
\hline Observações & 1018 & 1018 & 1018 \\
\hline
\end{tabular}

Nota: elaborado pelo autor a partir dos dados do LAPOP (2014). A variável dependente assume o valor 1 se o indivíduo concorda com a proposição de que o governo deve implementar políticas firmes para reduzir a desigualdade de renda entre pobres e ricos, e 0 , caso contrário. 
Tabela 54 - Percepção da desigualdade dos beneficiários do CS por filiação religiosa (2014)

\begin{tabular}{|c|c|c|c|}
\hline & $\begin{array}{c}(1) \\
\text { Desigualdade }\end{array}$ & $\begin{array}{c}(2) \\
\text { Desigualdade }\end{array}$ & $\begin{array}{c}(3) \\
\text { Desigualdade }\end{array}$ \\
\hline CS X PENT & $\begin{array}{l}0.0559 \\
(0.31)\end{array}$ & & \\
\hline CS X TRAD & & $\begin{array}{l}0.115^{* * *} \\
(4.19)\end{array}$ & \\
\hline CS X CATOL & & & $\begin{array}{l}-0.0192 \\
(-0.30)\end{array}$ \\
\hline Idade & $\begin{array}{l}0.000254 \\
(0.31)\end{array}$ & $\begin{array}{l}0.000255 \\
(0.31)\end{array}$ & $\begin{array}{l}0.000227 \\
(0.28)\end{array}$ \\
\hline Gênero & $\begin{array}{l}0.00389 \\
(0.14)\end{array}$ & $\begin{array}{l}0.00396 \\
(0.15)\end{array}$ & $\begin{array}{l}0.00407 \\
(0.15)\end{array}$ \\
\hline Raça & $\begin{array}{l}-0.0358^{*} \\
(-2.19)\end{array}$ & $\begin{array}{l}-0.0356^{*} \\
(-2.18)\end{array}$ & $\begin{array}{l}-0.0358^{*} \\
(-2.19)\end{array}$ \\
\hline Escolaridade & $\begin{array}{l}-0.00452 \\
(-0.20)\end{array}$ & $\begin{array}{l}-0.00464 \\
(-0.20)\end{array}$ & $\begin{array}{l}-0.00462 \\
(-0.20)\end{array}$ \\
\hline Renda & $\begin{array}{l}-0.00927^{* *} \\
(-2.87)\end{array}$ & $\begin{array}{l}-0.00920^{* *} \\
(-2.83)\end{array}$ & $\begin{array}{l}-0.00938^{* *} \\
(-2.90)\end{array}$ \\
\hline Urbano & $\begin{array}{l}0.171^{* * *} \\
(4.53)\end{array}$ & $\begin{array}{l}0.170^{* * *} \\
(4.51)\end{array}$ & $\begin{array}{l}0.171^{* * *} \\
(4.54)\end{array}$ \\
\hline Religiosidade & $\begin{array}{l}-0.0392 \\
(-1.49)\end{array}$ & $\begin{array}{l}-0.0379 \\
(-1.44)\end{array}$ & $\begin{array}{l}-0.0383 \\
(-1.46)\end{array}$ \\
\hline Constante & $\begin{array}{l}0.814^{* * *} \\
(9.84)\end{array}$ & $\begin{array}{l}0.813^{* * *} \\
(9.82)\end{array}$ & $\begin{array}{l}0.817^{* * *} \\
(9.89)\end{array}$ \\
\hline Observações & 1014 & 1014 & 1014 \\
\hline
\end{tabular}

Estatística $t$ entre parênteses.

$\ddagger p<0.10^{*} p<0.05,{ }^{* *} p<0.01,^{* * *} p<0.001$

Nota: elaborado pelo autor a partir dos do LAPOP (2014). A variável dependente assume valor 1 se o indivíduo concorda que a diferença na distribuição de rendimentos é demasidamente grande, e 0 , caso contrário. 
Tabela 55 - Aversão à taxação dos beneficiários do CS por filiação religiosa (2014)

\begin{tabular}{|c|c|c|c|}
\hline & $\begin{array}{c}(1) \\
\text { Taxação }\end{array}$ & $\begin{array}{c}(2) \\
\text { Taxação }\end{array}$ & $\begin{array}{c}(3) \\
\text { Taxação }\end{array}$ \\
\hline CS X PENT & $\begin{array}{l}0.0320 \\
(0.18)\end{array}$ & & \\
\hline CS X TRAD & & $\begin{array}{r}0.117 \\
(0.42)\end{array}$ & \\
\hline CS X CATOL & & & $\begin{array}{l}0.0674 \\
(0.93)\end{array}$ \\
\hline Idade & $\begin{array}{l}-0.000740 \\
(-0.89)\end{array}$ & $\begin{array}{l}-0.000732 \\
(-0.88)\end{array}$ & $\begin{array}{l}-0.000714 \\
(-0.86)\end{array}$ \\
\hline Gênero & $\begin{array}{l}-0.00344 \\
(-0.12)\end{array}$ & $\begin{array}{l}-0.00349 \\
(-0.12)\end{array}$ & $\begin{array}{l}-0.00338 \\
(-0.12)\end{array}$ \\
\hline Raça & $\begin{array}{l}0.0178 \\
(1.20)\end{array}$ & $\begin{array}{l}0.0179 \\
(1.21)\end{array}$ & $\begin{array}{l}0.0184 \\
(1.24)\end{array}$ \\
\hline Escolaridade & $\begin{array}{l}-0.0105 \\
(-0.42)\end{array}$ & $\begin{array}{l}-0.0105 \\
(-0.42)\end{array}$ & $\begin{array}{l}-0.0103 \\
(-0.41)\end{array}$ \\
\hline Renda & $\begin{array}{l}0.00169 \\
(0.51)\end{array}$ & $\begin{array}{l}0.00178 \\
(0.55)\end{array}$ & $\begin{array}{l}0.00191 \\
(0.58)\end{array}$ \\
\hline Urbano & $\begin{array}{l}0.104^{* * *} \\
(3.39)\end{array}$ & $\begin{array}{l}0.103^{* * *} \\
(3.37)\end{array}$ & $\begin{array}{l}0.103^{* * *} \\
(3.36)\end{array}$ \\
\hline Religiosidade & $\begin{array}{l}0.0724^{*} \\
(2.55)\end{array}$ & $\begin{array}{l}0.0735^{* *} \\
(2.61)\end{array}$ & $\begin{array}{l}0.0722^{*} \\
(2.56)\end{array}$ \\
\hline Constante & $\begin{array}{r}0.126 \\
(1.52)\end{array}$ & $\begin{array}{c}0.124 \\
(1.50)\end{array}$ & $\begin{array}{r}0.119 \\
(1.44)\end{array}$ \\
\hline Observações & 1003 & 1003 & 1003 \\
\hline
\end{tabular}

Estatística $t$ entre parênteses.

${ }^{\ddagger} p<0.10^{*} p<0.05,{ }^{* *} p<0.01,{ }^{* * *} p<0.001$

Nota: elaborado pelo autor a partir dos dados do LAPOP (2014). A variável dependente assume valor 1 se o indivíduo está de acordo em pagar mais impostos se estes forem utilizados para dar mais àqueles que têm menos, e 0 , caso contrário. 
Anexos 



\section{ANEXO A - A opinião de Edir Macedo}

\section{(IURD) sobre a prática do aborto}

O texto abaixo, originalmente publicado no dia 03 de Setembro de 2010, foi retirado do "Blog da Universal", ambiente virtual da IURD onde seu líder, Bispo Edir Macedo, debate temas do cotidiano à luz de sua interpretação da Bíblia.

Disponível em: https:/ /blogs.universal.org/bispomacedo/2010/09/03/jesusfala-sobre-o-aborto/. Acesso em: 26 de Setembro de 2019.

\section{Jesus fala sobre o aborto}

"Contra fatos não há argumentos, já diz o jargão popular. E quando o assunto é aborto, os fatos são comprovados por estatísticas, como a do Instituto Guttmacher, divulgada recentemente, de que cerca de 70 mil mulheres morrem por ano no mundo, vítimas de abortos clandestinos.

Estupro, pedofilia, gravidez precoce, violência doméstica, entre outros, são alguns dos fatores que têm levado mulheres e adolescentes a buscar clínicas clandestinas para porem fim a uma gravidez indesejada, submetendo-se a procedimentos arriscados, devido à falta de condições hospitalares adequadas para atendê-las, principalmente caso aconteça alguma complicação.

Eu sempre digo que sou a favor do aborto, não indiscriminadamente, mas em determinadas circunstâncias. Não faço isso para declarar guerra a nenhuma religião ou 
à parcela da sociedade que é contra o procedimento. Tenho esta opinião principalmente porque a fé que eu professo me impede de exaltar a hipocrisia. $\mathrm{O}$ aborto não é a causa do problema, é o efeito. O problema começa antes, na falta de informação, principalmente às camadas financeiramente menos favorecidas; na falta de ações preventivas; nas inúmeras questões sociais que têm levado à destruição de lares e à banalização da família.

Diversas manifestações sociais, políticas e religiosas condenam a legalização do aborto, em nome da "defesa da vida", mas parecem ignorar ou não dar o mesmo valor à vida de crianças que nasceram indesejadas ou em famílias sem a menor condição de criá-las, e que andam por aí, revirando lixo para se alimentar, expostas a todo tipo de doença e violência nas ruas. Também não parecem se importar com a vida de meninas e mulheres que morrem diariamente em clínicas de aborto clandestino.

As bandeiras e cartazes que estas pessoas e instituições levantam contra o aborto lhes encobrem a visão e as impede de enxergar a verdade dos fatos. As mulheres não vão sair por aí aumentando o número de abortos praticados, caso a legislação aprove o procedimento e deixe de considerá-las criminosas. Ninguém deixa de fazer um aborto porque ele é proibido por lei. O que pode sim acontecer é uma expressiva diminuição dos índices de mortalidade feminina e do número de crianças pobres, desnutridas e vítimas de todo tipo de abuso por serem pobres e abandonadas.

Para os que acreditam não haver embasamento bíblico no que eu digo, cito o momento em que o Senhor Jesus sentou-se à mesa com seus discípulos para celebrar a última ceia, antes de ser torturado e morto. Ele anunciou que ali estava presente quem O trairia, e sentenciou: “O Filho do homem vai, como está escrito a seu respeito, mas ai daquele por intermédio de quem o Filho do homem está sendo traído! Melhor lhe fora 
não haver nascido!" Mateus 26-24

No meu entendimento, essa última frase pode ser interpretada como: seria melhor que Judas tivesse sido abortado. Melhor do que o futuro de sua alma". 